



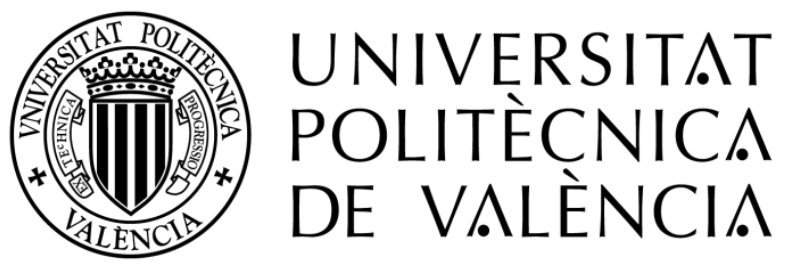

TESIS DOCTORAL

Nuevas herramientas en la lucha contra las virosis del pimiento

Presentada por:

VICENTE PASCUAL IBIZA GIMENO

Para optar al título de Doctor Ingeniero Agrónomo

por la Universidad Politécnica de Valencia

Dirigida por:

Dr. D. Joaquín Cañizares Sales

Dr. D. Fernando Nuez Viñals

Valencia, 2011 



\section{AGRAÏMENTS}

El poder fer aquesta tesi doctoral no havera estat possible sense contar amb l'ajuda, a tots els nivells, d'un conjunt de persones.

En primer lloc agrair a Dr. Fernando Nuez la confiança dipositada amb mi per permetrem treballar al COMAV i per poder portar endavant aquesta tesis doctoral. Agrair també al Dr. Joaquín Cañizares per la seua gran ajuda i per resoldrem tots els problemes que han anat eixint al llarg de la tesis.

Per altra part, agrair a tota la gent del COMAV (Laura P., Carolina, Julia, Ana P., Jaime C., Inma, Carmelo, José B., Peio, María José P., J. Vicente, Santi, Belen, Jaume P. ....) o que han treballat a l' institut (Montse, Elena, Laura C., Maria G., Pablo...), tant els bons com els mals moments que hem passat. Al ser la llista tan llarga i per a no deixar-me a cap company, el meu sincer agraïment a tots.

Gracies a les meus amistats que en algun moment s' han preocupat per com anava la tesis (Ximo, Judit, Carrillo, Mari, Clara, Andrés, Alfonso, Luis ...). Els agreix el recolzament.

També vull destacar totes aquelles persones que han participat en la meua educació, des de l' escola Ribalta d'Algemesí fins a la Universitat Politècnica de Valencia.

Respecte a la família, agrair als meus pares, Pasqual $i$ Vicen, el gran recolzament que sempre he tingut d' ells sense demanar res a canvi. Al meu germà Jordi el seu suport. Com no, a la meua dona, la meua Mara, la peça fonamental d' haver acabat aquesta tesis, moltísimes gracies per aguantar-me els meus canvis bruscos d'ànim, les hores de treball $i$ tot allò que ha rodejat la tesis. Moltes gracies per fer-me caminar sempre cap a endavant i confiar tant amb mi. Se que sempre estaràs per a ajudar-me, aguantar-me, entendrem ..... en qualsevol cosa. I al nou de la família, el meu nebodet Iker, que sense saber-ho els caps de setmana que el visitava, desconnectava.

Finalment als que no estan però sempre estaran amb mi, Joaquín i Tica, Xilo i María. 

Als meus i al llaurador valencià 



\section{RESUMEN}

Las hortalizas en general, entre ellas los pimientos, se encuentran continuamente expuestas al ataque de patógenos. No obstante, las enfermedades de etiología viral destacan por ser el principal factor limitante de estos cultivos. La estrategia más eficaz para el control de las virosis en plantas consiste en la identificación de genes de resistencia y su posterior utilización para el desarrollo de variedades resistentes. Una importante parte de la variabilidad existente en el género Capsicum se encuentra conservada en bancos de germoplasma. Sin embargo, para poder manejarla y explotarla eficientemente es necesario cuantificar y analizar la variabilidad interespecífica e intraespecífica disponible. Además, el disponer de una estrategia capaz de disminuir los costes asociados al proceso de fenotipado será muy ventajoso.

El principal objetivo de esta tesis se centra en la caracterización y aprovechamiento de la variabilidad genética de las especies cultivadas del género Capsicum (C. annuum, $C$. chinense, $C$. frutescens, $C$. baccatum y $C$. pubescens). Así, en este trabajo se plantea tanto conocer y describir la distribución de la variabilidad existente en estas especies, como desarrollar herramientas que permitan una exploración y utilización eficiente de la variabilidad contenida en los bancos de germoplasma. Para ello, se ha puesto a punto una plataforma de EcoTILLING que permite un cribado eficiente de la colección de entradas de Capsicum del Banco de Germoplasma del COMAV. A modo de experiencia piloto se exploró esta plataforma para la búsqueda de variantes alélicas de los genes eIF4E y eIF(iso) $4 E$, implicados en la resistencia a virosis de gran importancia en el cultivo del pimiento y de otros cultivos.

Esta tesis doctoral es un ejemplo donde el EcoTILLING basado en el ADNc resulta fructífero, al trabajar con diferentes especies del género Capsicum y al ser los cambios nucleotídicos de las regiones codificantes los más interesantes. La utilización en la técnica EcoTILLING del ADN complementario como material de partida, en vez del ADN genómico, no se había descrito previamente. El ADNc favorece la amplificación de los genes candidatos en un conjunto de especies relacionadas. Además, reduce el número de amplificaciones y reacciones enzimáticas por muestra. 36 SNPs se detectaron en las 21 secuencias identificadas del gen eIF4E y 26 SNPs en las 17 secuencias del eIF(iso)4E, confirmándose el elevado nivel de polimorfismo presente en esta colección de entradas. Finalmente, se identificaron 19 variantes de la proteína eIF4E y 10 de la eIF(iso)4E. De estas, cinco proteínas eIF4E y una eIF(iso)4E habían sido publicadas previamente. Es decir, la plataforma de EcoTILLING contiene una buena representación de la variabilidad genética del género Capsicum.

Una colección de 31 entradas que representan distintas combinaciones de los alelos eIF4E y eIF(iso)4E se inocularon mecánicamente con el Potato virus $Y$ (PVY) y el Tobacco etch virus (TEV). Cinco nuevas variantes del gen eIF4E ( $p v r 2^{10}, p v r 2^{11}, p v r 2^{12}, p v r 2^{13}$, $p v r 2^{14}$ ) están relacionadas con la respuesta de resistencia al PVY y al TEV. Las plantas que 
contienen alguno de estos alelos no se infectan sistemáticamente con el aislado PVY-F14K. Por otra parte, estos alelos no inhiben la replicación del aislado TEV-7DA, al igual que sucede en las entradas con alelos publicados como resistentes al TEV ( $p v r 1$ y $p v r 2^{2}$ ). No obstante, las entradas que poseen estos alelos desarrollan una respuesta tolerante frente al TEV-7DA.

Los nuevos alelos de resistencia poseen cambios aminoacídicos localizados en las regiones I (exón 1) y II (exón 2) de la proteína eIF4E. Estos parecen ser los responsables de las respuestas frente al PVY-F14K y el TEV-7DA. Las proteínas eIF4E de los alelos $p v r 2^{12}$, $p v r 2^{13}$ y $p v r 2^{14}$ de $C$. baccatum y $p v r 2^{11}$ de $C$. chinense tienen el cambio N65D. Por otra parte, la combinación de cambios aminoacídicos en la proteína eIF4E del alelo $p v r 2^{10}$ de $C$. chinense podría explicar las reacciones de este alelo.

La determinación de las relaciones filogenéticas, en el caso del género Capsicum, tiene una gran importancia agronómica. Las distintas especies son potenciales fuentes de variabilidad para ser utilizadas en la mejora del cultivo del pimiento ( $C$. annuиm). Diez microsatélites y cuatro combinaciones de AFLPs se utilizaron para caracterizar 260 entradas del género Capsicum. El análisis molecular ha verificado la estrecha relación entre las especies $C$. chinense y $C$. frutescens. En cuanto a las especies silvestres $C$. cardenasii y $C$. eximium son indistinguibles molecularmente, mientras $C$. baccatum y $C$. praetermissum son especies distintas que forman un grupo muy compacto. En base a nuestras observaciones y a diferencia de otros estudios, $C$. chacoense es incluida en el complejo de C. baccatum mientras $C$. tovarii no pertenece a ningún complejo.

Además del análisis general de la taxonomía se detectó la existencia de cierta estructuración intraespecífica. C. baccatum y $C$. pubescens muestran un par de grupos genéticos, por un lado están las entradas procedentes de Bolivia y por el otro las entradas de Ecuador y Perú. Además, las entradas de $C$. chinense procedentes de Perú pudieron ser diferenciadas del resto. Diferentes factores han podido favorecer esta diferenciación genética. En Bolivia, Ecuador y Perú el uso de los frutos de pimiento para el autoconsumo está relacionado con aspectos culturales. Por otra parte C. pubescens y C. baccatum se cultivan en las regiones montañosas de estos países. En éstas las comunicaciones son complicadas y por tanto el intercambio de semillas es más difícil. Así, como resultado de la selección continua y el aislamiento genético se ha podido producir la diferenciación genética detectada.

En este estudio las entradas de Ecuador y Perú han mostrado una diversidad elevada y similar a las de Bolivia, el cual es un importante centro de diversidad del género Capsicum. Por tanto, las entradas procedentes de estos países podrán constituir fuentes importantes de variación para ser utilizadas en los programas de mejora del pimiento. Los datos de distribución de la variabilidad aumentarán la eficacia del manejo de las entradas, y permitirán rediseñar la plataforma de Capsicum para analizarla mediante EcoTILLING o con las nuevas metodologías de detección de mutaciones. 


\begin{abstract}
Vegetables, including peppers, are continuously exposed to pathogen attack. However, viral diseases stand out as the main limiting factor for these crops. The best strategy to control these diseases is the identification of resistance genes and their employment to develop resistant varieties. To that end, it is important to exploit the variability present in these species that in the Capsicum genus is maintained at gene banks. However, to efficiently handle and exploit the resources is necessary to quantify and analyze inter- and intraspecific variability. In addition, any strategy to reduce the costs of the phenotyping process will be really advantageous.

The main objective of this thesis is focused on the characterization and utilization of the genetic variability present in the cultivated species of the Capsicum genus ( $C$. annuum, C. chinense, C. frutescens, C. baccatum and C. pubescens). Thus, this work expects to analyze and describe the distribution of the variability in these species, and to develop tools that allow efficient exploration and utilization of the variability maintained in gene banks. To that end, an EcoTILLING platform has been developed to allow efficient screening of the Capsicum accession collection from the COMAV gene bank. As a pilot experiment, this platform was explored to search for allelic variants of genes eIF4E and eIF(iso)4E, involved in resistance to viruses in pepper crops and other crops.

This work is an example where EcoTILLING based on cDNA is both cost- and timeeffective: it involves different species of the genus Capsicum and only mutations in the coding sequences, the most interesting, are detected. The use of cDNA as starting material instead of genomic DNA had not been previously described. cDNA makes the amplification of candidate genes in a group of closely related species easier and reduces number of amplification cycles and enzymatic reactions per sample. 36 SNPs were detected in the 21 coding sequences of the eIF4E gene as well as 26 changes in the 17 eIF(iso) $4 E$ sequences. This result shows that the pepper accession collection used is highly variable. Finally, 19 different eIF4E proteins and 10 eIF(iso)4E were identified. Of these, five eIF4E proteins and one eIF(iso)4E have been previously published, confirming that our EcoTILLING platform contains a good representation of Capsicum variability.

A collection of 31 accessions that represents eIF4E/eIF(iso)4E allele combinations was mechanically inoculated against Potato virus $Y$ (PVY) and Tobacco etch virus (TEV). Five new eIF4E alleles $\left(p v r 2^{10}, p v r 2^{11}, p v r 2^{12}, p v r 2^{13}, p v r 2^{14}\right)$ are related to resistance responses to PVY and TEV. The plants carrying any of these alleles do not show PVYF14K systemic infection. On the other hand, these alleles do not block TEV-7DA isolate replication, like the accessions with resistance alleles previously published ( $p v r 1$ or $p v r 2^{2}$ ). However, the accessions with PVY-F14K resistance alleles showed a highly promising tolerant response against TEV-7DA.
\end{abstract}


The new resistance alleles have non-conservative amino acid changes localized in regions I (exon 1) and II (exon 2) of the eIF4E protein. These changes seem to be responsible for the resistance against PVY-F14K and TEV-7DA. The eIF4E proteins coded for $C$. baccatum alleles $p v r 2^{12}, p v r 2^{13}, p v r 2^{14}$ and $C$. chinense allele $p v r 2^{11}$ have the same amino acid substitution, N65D. On the other hand, the combination of several amino acid changes in the eIF4E protein from $C$. chinense allele $p v r 2^{10}$, could explain the responses caused by this allele.

The study of the phylogenetic relationships between the species of the Capsicum genus is of great agronomic relevance. These species are potential variability sources to be used for C. annuum breeding. Ten microsatellites and four AFLP combinations were used to characterize 260 Capsicum accessions. The molecular analysis clearly verified the close relationships between $C$. chinense and $C$. frutescens. The results also showed that wild species $C$. cardenasii and $C$. eximium are molecularly indistinguishable, whereas $C$. baccatum and $C$. praetermissum are distinct species that form a very compact group. In this work, in contrast to other studies, $C$. chacoense is placed in the $C$. baccatum complex and C. tovarii is not clearly member of any Capsicum complex.

In addition to the taxonomy analysis intraspecific differentiations were identified. $C$. baccatum and $C$. pubescens show a pair of genetic groups that correspond to Bolivian accessions and to the Peruvian-Ecuadorian accessions. Besides, the $C$. chinense accessions from Peru could be differentiated from the rest of the accessions. Different factors may have enhanced this genetic differentiation. In Bolivia, Ecuador and Peru, the use of these species fruits for self-consumption is related to cultural aspects. On the other hand, C. pubescens and $C$. baccatum are cultivated in mountainous regions of these countries, where access is complicated, making seed exchange more difficult. Thus, continuous selection and genetic isolation, may have caused the genetic differentiation observed.

In this study, accessions from Ecuador and Peru have shown high and similar diversity to Bolivian accessions. Being Bolivia an important center of diversity for the Capsicum genus, accessions from these countries may be a natural genetic heritage, which could be employed for the pepper breeding programs. The data on the distribution of genetic variability will increase management effectiveness of accessions, and will allow to redesign the Capsicum platform for analysis by EcoTILLING or new mutations isolation techniques. 


\section{RESUM}

Les hortalisses en general, entre elles els pimentons, és troben contínuament exposades a l' atac de patògens. No obstant això, les malalties d' etiologia viral destaquen per ser el principal factor limitant d' aquests cultius. L' estratègia més eficaç per al control de les virosis en plantes consisteix en la identificació de gens de resistència i la seua posterior utilització per al desenvolupament de varietats resistents. Una important part de la variabilitat existent en el gènere Capsicum és troba conservada als bancs de germoplasma. No obstant això, per a poder manejar-la i explotar-la eficientment és necessari quantificar i analitzar la variabilitat interespecífica e intraespecífica disponible. A més, el disposar d' una estratègia capaç de disminuir els costos associats al procés de fenotipat serà molt avantatjós.

El principal objectiu d' aquesta tesi es centra en la caracterització i aprofitament de la variabilitat genètica de les espècies cultivades del gènere Capsicum ( $C$. annuum, $C$. chinense, $C$. frutescens, $C$. baccatum i $C$. pubescens). Així, en aquest treball es planteja tant conèixer i descriure la distribució de la variabilitat existent en aquestes espècies, com desenvolupar ferramentes que permeten una exploració i utilització eficient de la variabilitat continguda als bancs de germoplasma. Per això, s' ha posat a punt una plataforma d' EcoTILLING que permet un garbellat eficient de la col-lecció d' entrades de Capsicum del Banc de Germoplasma del COMAV. Com a experiència pilot es va explorar aquesta plataforma per a la recerca de variants al-lèliques dels gens eIF4E i eIF(iso)4E, implicats en la resistència a virosis de gran importància al cultiu del pimentó i d' altres cultius.

Aquesta tesi doctoral és un exemple on 1' EcoTILLING basat en l' ADNc resulta fructífer, al treballar amb diferents espècies del gènere Capsicum $\mathrm{i}$ al ser els canvis nucleotídics de les regions codificants els més interessants. La utilització a la tècnica EcoTILLING de l' ADN complementari com a material de partida, en compte de l' ADN genòmic, no havia sigut descrita prèviament. L' ADNc afavoreix l' amplificació dels gens candidats en un conjunt $d$ ' espècies relacionades. A més, redueix el nombre $d$ ' amplificacions i reaccions enzimàtiques per mostra. 36 SNPs van ser detectats en les 21 sequiències identificades del gen eIF4E i 26 SNPs en les 17 seqüències del eIF(iso)4E, confirmant-se l' elevat nivell de polimorfisme d' aquesta col-lecció d' entrades. Finalment, es van identificar 19 variants de la proteïna eIF4E i 10 de la eIF(iso)4E. D' aquestes, cinc proteïnes eIF4E i una eIF(iso)4E havien sigut publicades prèviament. És a dir, la plataforma d' EcoTILLING conté una bona representació de la variabilitat genètica del gènere Capsicum.

Una col·lecció de 31 entrades que representen diferents combinacions dels al·lels eIF4E i eIF(iso)4E van ser inoculades mecànicament amb el Potato virus $Y$ (PVY) i el Tobacco etch virus (TEV). Cinc noves variants del gen eIF4E $\left(p v r 2^{10}, p v r 2^{11}, p v r 2^{12}\right.$, $p v r 2^{13}, p v r 2^{14}$ ) estan relacionades amb la resposta de resistència al PVY $i$ al TEV. Les plantes que contenen algun d' aquests al-lels no s' infecten sistemàticament amb l' aïllat 
PVY-F14K. D' altra banda, aquests al·lels no inhibeixen la replicació de 1' aïllat TEV-7DA, igual que succeeix en les entrades amb al-lels publicats com a resistents al TEV ( $p v r l \mathrm{i}$ $\left.p v r 2^{2}\right)$. No obstant això, les entrades que posseeixen aquests al·lels desenvolupen una resposta tolerant front al TEV-7DA.

Els nous al·lels de resistència posseeixen canvis aminoacídics localitzats a les regions I (exó 1) i II (exó 2) de la proteïna eIF4E. Aquests pareixen ser els responsables de les respostes front al PVY-F14K i al TEV-7DA. Les proteïnes eIF4E dels al-lels $p v r 2^{12}, p v r 2^{13}$ i $p v r 2^{14}$ de $C$. baccatum i $p v r 2^{11}$ de $C$. chinense tenen el canvi N65D. D' altra banda, la combinació de canvis aminoacídics a la proteïna eIF4E de 1 ' al·lel $p v r 2^{10}$ de $C$. chinense podria explicar les reaccions d' aquest.

La determinació de les relacions filogenètiques, al cas del gènere Capsicum, té una gran importància agronòmica. Les diferents espècies són potencials fonts de variabilitat per a ser utilitzades a la millora del cultiu del pimentó (C. annuиm). Deu microsatèl-lits i quatre combinacions d' AFLPs es van utilitzar per a caracteritzar 260 entrades del gènere Capsicum. L' anàlisi molecular ha verificat l' estreta relació entre les espècies $C$. chinense i C. frutescens. Quant a les espècies silvestres $C$. cardenasii i C. eximium són indistingibles molecularment, mentre $C$. baccatum i $C$. praetermissum són espècies diferents que formen un grup molt compacte. Basant-se en les nostres observacions i a diferència d' altres estudis, $C$. chacoense és inclosa en el complex de $C$. baccatum mentre $C$. tovarii no pertany a cap complex.

A més de l' anàlisi general de la taxonomia es va detectar l' existència d' una certa estructuració intraespecífica. C. baccatum i $C$. pubescens mostren un parell de grups genètics, per un costat estan les entrades procedents de Bolívia i per l' altre les entrades d' Equador i Perú. A més, les entrades de $C$. chinense procedents de Perú van poder ser diferenciades de la resta. Diferents factors han pogut afavorir aquesta diferenciació genètica. A Bolívia, Equador i Perú l' ús dels fruits de pimentó per a l' autoconsum està relacionat amb aspectes culturals. D' altra banda C. pubescens i C. baccatum es cultiven a les regions muntanyoses d' aquests països. En aquestes les comunicacions són complicades i per tant l' intercanvi de llavors és més difícil. Així, com a resultat de la selecció contínua i l' aïllament genètic s' ha pogut produir la diferenciació genètica detectada.

En aquest estudi les entrades d' Equador i Perú han mostrat una diversitat elevada i semblant a les de Bolívia, el qual és un important centre de diversitat del gènere Capsicum. Per tant, les entrades procedents d' aquests països podran constituir fonts importants de variació per a ser utilitzades als programes de millora del pimentó. Les dades de distribució de la variabilitat augmentaran l' eficàcia del maneig de les entrades, i permetran redissenyar la plataforma de Capsicum per a analitzar-la per mitjà de l' EcoTILLING o amb les noves metodologies de detecció de mutacions. 


\section{ÍNDICE}





\section{INTRODUCCIÓN}

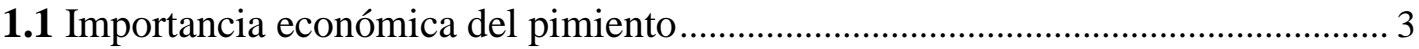

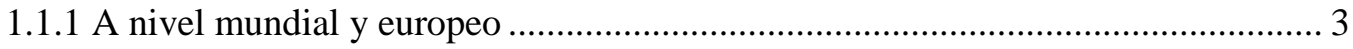

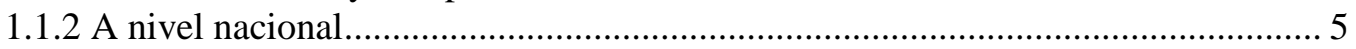

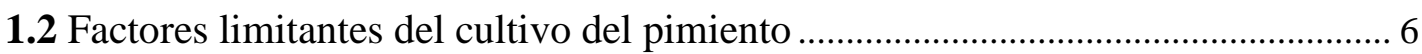

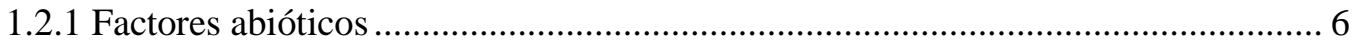

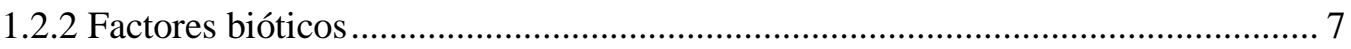

1.2.2.1 Las plagas y enfermedades del pimiento ........................................................... 7

1.2.2.2 Las enfermedades víricas más limitantes del pimiento .................................... 8

1.3 La importancia de los recursos fitogenéticos para el desarrollo

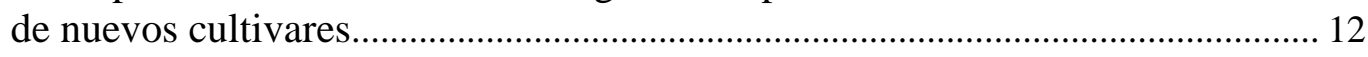

1.3.1 Especies cultivadas del género Capsicum ........................................................ 13

1.3.2 Relaciones de cruzabilidad entre las especies cultivadas ........................................ 14

1.3.3 Aprovechamiento de la variabilidad genética conservada

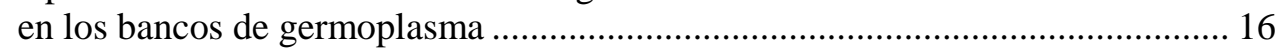

1.3.4 Fuentes de resistencia a patógenos identificadas en Capsicum ............................ 18

1.3.5 Los factores de iniciación a la traducción como responsables

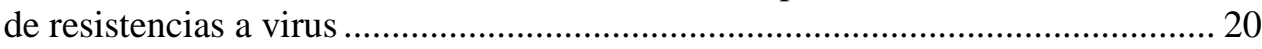

1.4 Aproximación metodológica en la identificación de fuentes

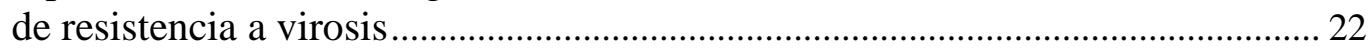

1.4.1 La metodología convencional basada en la caracterización fenotípica ................. 23

1.4.2 Nuevas aproximaciones biotecnológicas para el rastreo de colecciones de germoplasma ........................................................................ 24

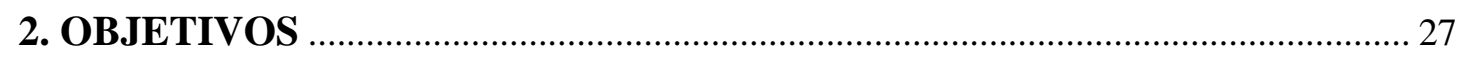

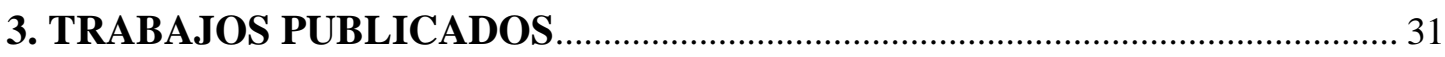

3.1 EcoTILLING in Capsicum species: searching for new virus resistances ............. 33

3.2 Exploiting the potential of pepper germplasm to identify new tolerance alleles of the eIF4E gene against Tobacco etch virus........................................... 51

3.3 Taxonomy and genetic diversity of domesticated Capsicum species

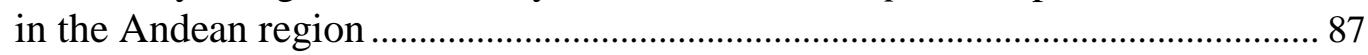

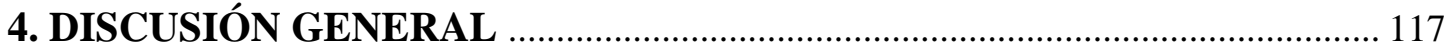

4.1 Ventajas e inconvenientes de la identificación de mutaciones mediante el EcoTILLING basado en el ADNc ............................................................... 119

4.2 La variabilidad del género Capsicum y su representación en la plataforma de EcoTILLING.....

4.3 La diferenciación regional en las especies domesticadas

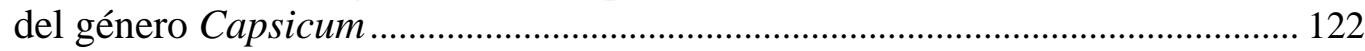

4.4 Las relaciones filogenéticas en el género Capsicum............................................. 124

4.5 La funcionalidad de las nuevas variantes alélicas de los genes eIF4E

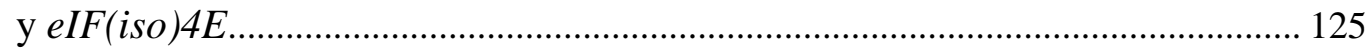

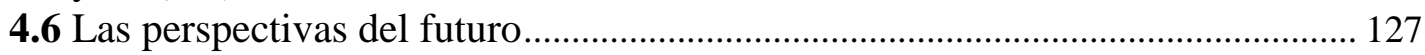

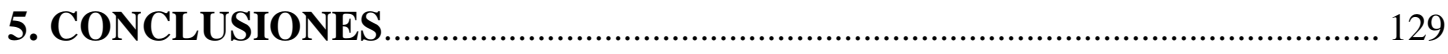

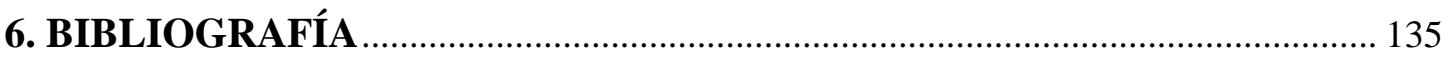

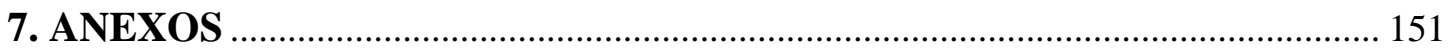



1. INTRODUCCIÓN 



\subsection{Importancia económica del pimiento}

\subsubsection{A nivel mundial y europeo}

La producción y superficie cultivada de pimiento (Capsicum spp.) ha aumentado constantemente a nivel mundial durante las últimas décadas (Figura 1.1). Esto es debido fundamentalmente a la obtención de variedades con mayores rendimientos por hectárea y a la fuerte inversión a nivel tecnológico que incide sobre este cultivo. Esta hortaliza es consumida durante todo el año y se comercializa en fresco, en forma de colorante o condimento, desecado para pimentón y en conserva. Al igual que el resto de cultivos importantes de la familia Solanaceae, tomates, patatas y berenjenas, los pimientos han llegado a ser un importante componente de las diversas culturas culinarias. Una de las causas de su creciente importancia puede ser atribuible a su pungencia, la cual ha hecho de ellos un importante condimento para las cocina de muchos países. Esto, junto a la proliferación de restaurantes étnicos y el mejor acceso a productos comestibles procedentes de países como México, India y Tailandia, ha favorecido la demanda y el cultivo del pimiento a nivel mundial (Crosby, 2008). Este aumento del consumo, tanto de las variedades pungentes como no pungentes, ha incentivado el cultivo de pimiento bajo invernadero en los países del norte, principalmente Holanda y Canadá, y también en los países del mediterráneo, como España e Israel, para poder cubrir la demanda creciente (Shaw y Cantliffe, 2003).

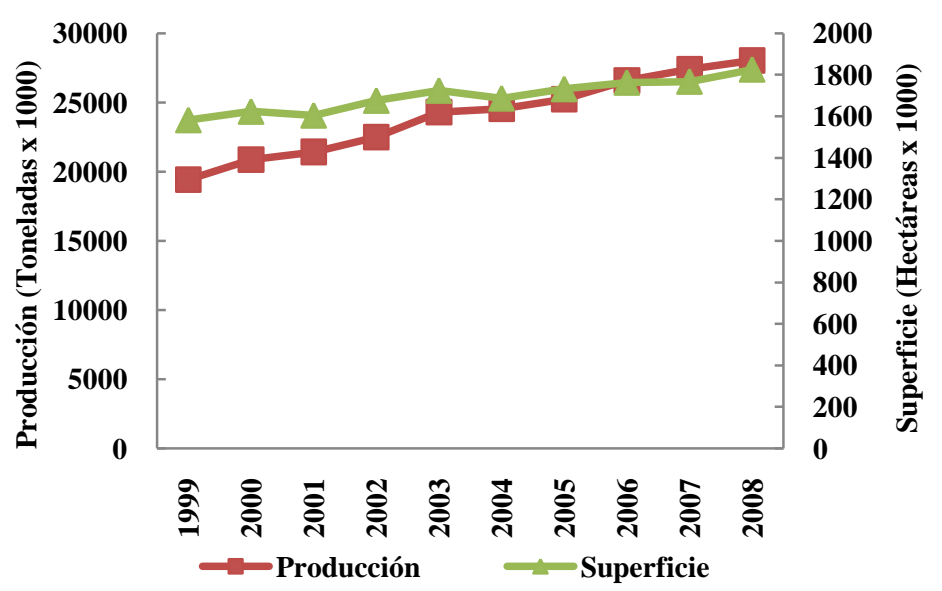

Figura 1.1: Evolución de la superficie cultivada y de la producción de pimiento verde a nivel mundial (FAO, 2011).

En el año 2008, según la Organización de las Naciones Unidas para la Agricultura y la Alimentación (FAO), el cultivo de pimiento verde alcanzó una producción a nivel mundial de 28 millones de toneladas, producidas en 1,8 millones de hectáreas; la 
producción destinada a pimiento seco fue de 3 millones de toneladas, cultivadas también en 1,8 millones de hectáreas (FAO, 2011). El cultivo está muy extendido a escala mundial practicándose, según la FAO, en una gran parte de los países del mundo. En la Figura 1.2 se observa cómo un $63 \%$ de la superficie cultivada se concentra en el continente asiático, situándose África por detrás de ella. Respecto al volumen de producción (Figura 1.3), Asia concentra más de la mitad de la producción mundial de pimiento (68\%), seguida a distancia por Europa (11\%) y América del Norte y Central $(11 \%)$.

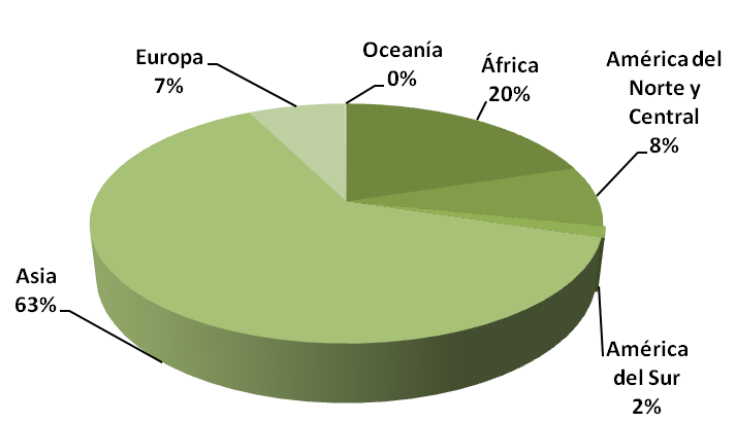

Figura 1.2: Distribución mundial de la superficie cultivada de pimiento verde en el año 2008 (FAO, 2011).

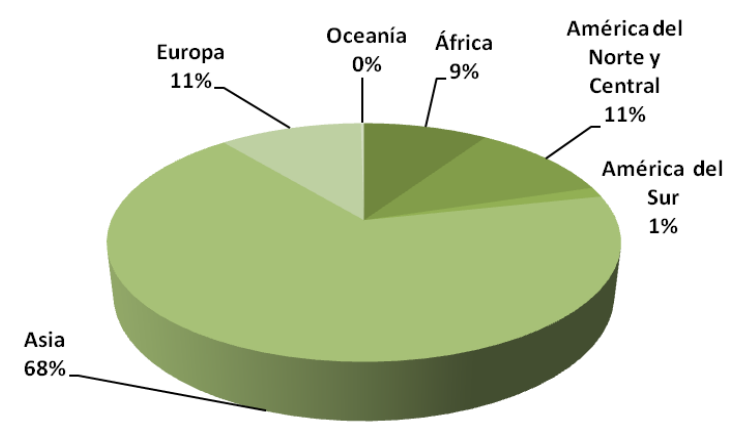

Figura 1.3: Distribución mundial de la producción de pimiento verde en el año 2008 (FAO, 2011).

Respecto a los rendimientos se puede afirmar que los países de Europa, América del Norte y Oceanía presentan rendimientos más elevados que aquellos de los países de África, Asia y Sud América. Destacando que los países de Europa occidental muestran los rendimientos más elevados. Esta mayor productividad se debe al esfuerzo tecnológico e investigador realizado. Como resultado ha permitido el desarrollo de nuevas técnicas de cultivo y variedades más productivas que permiten un continuo aumento de los rendimientos.

En la Unión Europea, durante el año 2008, se alcanzaron los 2,9 millones de toneladas de pimiento para consumo en fresco que ocuparon una superficie de 122.182 ha (FAO, 2011), y 92.551 toneladas de pimiento seco, producidas en 43.480 ha. Dentro de la Unión Europea, España es el país con el mayor volumen de producción de pimiento para consumo en fresco, el $42 \%$ de la producción total europea. Le siguen Los Países Bajos e Italia con el 14 \% de la producción cada uno. Respecto al pimiento seco, 
Bosnia y Herzegovina, Rumania y Hungría alcanzan el $83 \%$ de la producción total, mientras España el $5 \%$.

\subsubsection{A nivel nacional}

El pimiento es uno de los cultivos hortícolas más importantes en España. Según el Anuario de Estadística Agraria (MARM, 2011), es el sexto cultivo hortícola en cuanto a superficie, precedido por el tomate, melón, lechuga, coliflor y cebolla. La superficie total destinada a cultivo era en 2008 de 18.681 ha, de las cuales 18.483 eran de regadío. Almería y Murcia poseen la mayor parte de la producción española de pimiento, centrándose en el cultivo protegido destinado al consumo en fresco. Otras zonas como Extremadura, están especializadas en el cultivo de variedades al aire libre, destinadas a la industria de transformación.

La producción total a nivel nacional para 2008 fue 918.140 toneladas. La producción se concentra en tres periodos de tiempo: un primer ciclo de invierno que va destinado fundamentalmente a la exportación, un segundo de primavera que va destinado al consumo interno y un tercero de verano destinado a la industria conservera y para el pimiento pimentonero (Maroto, 2002). España es uno de los países que dedica una mayor parte de su producción a la exportación, unas 350.000 toneladas en el año 2008 (FAO, 2011). Los principales países destino de las exportaciones españolas dentro de la UE son Alemania, Reino Unido y Francia. Alrededor de un $10 \%$ de la producción en el año 2008 fue destinado a la transformación industrial (MARM, 2011).

La evolución de la superficie de cultivo y del volumen de producción en los últimos años en el estado español muestra que, desde 1990 a 2006, la superficie cultivada ha disminuido lentamente mientras que la producción ha experimentado un moderado y continuo aumento (MARM, 2011) (Figura 1.4). Sin embargo, en los últimos años se está produciendo una importante disminución de la superficie cultivada y, por consiguiente, de la producción. Esta disminución de la superficie cultivada es debida probablemente a la incidencia de plagas y enfermedades. 


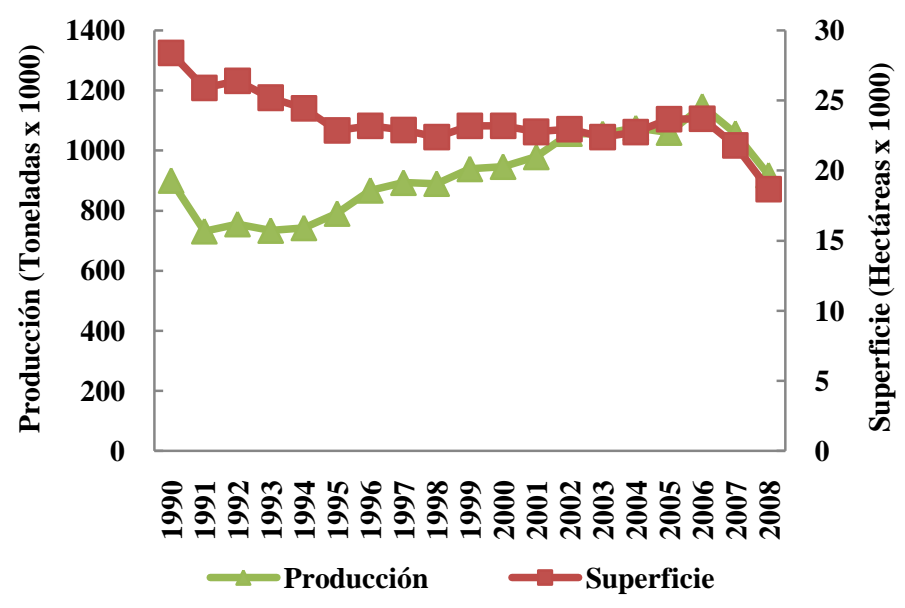

Figura 1.4: Evolución de la superficie cultivada y de la producción de pimiento verde en España (FAO, 2011).

\subsection{Factores limitantes del cultivo del pimiento}

Aunque en la actualidad los agricultores disponen de un conjunto de variedades mejoradas, con elevados rendimientos y adaptadas a las exigencias de cada mercado en particular, en el campo pueden concurrir distintos problemas de naturaleza abiótica o biótica que limitan el rendimiento económico de la actividad agrícola.

\subsubsection{Factores abióticos}

La necesidad de aumentar la producción de los cultivos para la alimentación humana ha provocado un uso abusivo de los recursos naturales. Este uso ha obligado a utilizar suelos agrícolas, aguas y climas en los que pueden favorecerse situaciones de estrés relacionados con la salinidad, sequía o temperaturas extremas. Sin embargo, el desarrollo de prácticas culturales ha minimizado las incidencias de los factores abióticos sobre los cultivos. Se dispone de infraestructuras que permiten la producción en zonas de clima frío y se han desarrollado productos fitosanitarios para solventar cualquier problema causado por la deficiencia de nutrientes. En otras ocasiones se han puesto a punto técnicas de polinización mediante el uso de determinados insectos que permiten o mejoran el cuajado de frutos en condiciones ambientales adversas. Además, la mejora genética ha participado en la lucha contra estos factores, mejorando la respuesta de las plantas frente a ellos. Se han desarrollado nuevas variedades con menores necesidades 
hídricas y nutritivas, con mayor resistencia a temperaturas extremas, a la salinidad o a iones tóxicos. Por tanto, se concluye que los factores abióticos no constituyen factores limitantes importantes de la producción de pimiento en los países desarrollados. Pero esto no es el caso de los factores bióticos, plagas y enfermedades.

\subsubsection{Factores bióticos}

En el caso de las plagas, las más importantes en el cultivo del pimiento son la araña roja (Tetranychus urticae K.), los minadores de hojas (Liriomyza trifolii B., Tuta absoluta M.), las orugas de lepidópteros (Autographa gamma L., Heliothis armigera H., Spodoptera littoralis B.), el mosquito verde (Empoasca lybica B.), las moscas blancas (Trialeuroides vaporariorum W., Bemisia tabaci G.), el trip (Frankliniella occidentalis P.) y los pulgones (Aphis gossypii G., Myzus persicae S.). Estas cinco últimas son de especial importancia por ser vectores de virosis, como el virus del bronceado del tomate (TSWV, Tomato spotted wilt virus) y el virus Y de la patata (PVY, Potato virus Y). Estos virus son unos de los factores limitantes más importantes del cultivo del pimiento en Europa. Respecto al control de estas plagas, los métodos de lucha biológica han ido ganando terreno y en la actualidad su utilización es una realidad. Los agricultores y técnicos se han adaptado a este nuevo método de control, más exigente en cuanto a conocimientos y dedicación. Sin embargo, el aumento de las poblaciones de insectos perjudiciales durante alguna fase del ciclo de cultivo puede obligar a la utilización de los productos fitosanitarios.

\subsubsection{Las plagas y enfermedades del pimiento}

En el caso de los parásitos del suelo, los daños más importantes los producen distintos nematodos del género Meloidogyne (Figura 1.5). Atacan a la planta, produciendo nódulos en las raíces que provocan la obstrucción de los vasos, evitándose la absorción de nutrientes por parte de estas. Esto provoca un menor desarrollo de la planta y el marchitamiento con temperaturas altas. El control requiere de la desinfección del suelo a partir de la solarización y biofumigación.

Con respecto a las enfermedades infecciosas, el cultivo del pimiento puede verse afectado por hongos como el oidio (Leveillula taurica L.), la botritis (Botrytis cinerea P.), la podredumbre blanca (Sclerotinia sclerotiorum B.), el mildiu (Phytophthora 
capsici L.), la alternariosis (Alternaria solani E. \& M.), el fusarium (Fusarium oxysporum S. \& H.) y el verticilium (Verticilium dahliae K.). Adquieren especial importancia los daños causados por Botrytis cinerea en el cultivo bajo invernadero y Phytophotora capsici, el agente causal de la enfermedad fúngica más extendida del pimiento (Gil Ortega, 1990). En el caso de las enfermedades de origen bacteriano, las más importantes son las causadas por especies pertenecientes a los géneros Clavibacter, Pseudomonas, Xanthomonas y Erwinia. Ninguna de ellas se caracteriza por causar daños de importancia en los cultivos de pimiento de nuestro país. Estos dos tipos de patologías, fúngicas y bacterianas, son de relativo fácil control mediante la aplicación de productos fitosanitarios. Ésta deberá realizarse cuando las condiciones climáticas son favorables para el desarrollo, y exista una gran cantidad de propágulos y bacterias.

Sin embargo, si nos referimos a las enfermedades víricas podemos destacar la gran complejidad que presenta su control en campo, debido a su facilidad de transmisión y a la ausencia de tratamientos curativos.
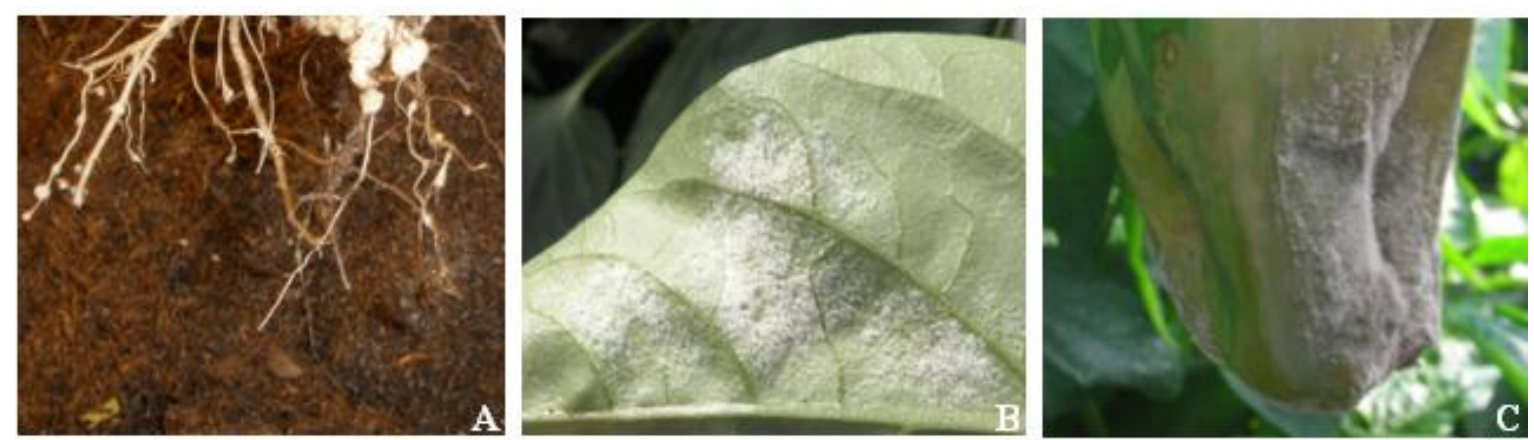

Figura 1.5: (A) Agallas causadas por nematodos del género Meloidogyne en raíces de pimiento., (B) Micelio blanquecino del hongo Leveillula taurica en el envés de una hoja de pimiento., (C) Podredumbre gris producida por el hongo Botrytis cinerea en un fruto de pimiento (cortesía de Laura Olalla).

\subsubsection{Las enfermedades víricas más limitantes del pimiento}

La planta de pimiento no escapa al ataque de los patógenos virales. Las enfermedades de etiología viral provocan grandes pérdidas económicas en casi todas las campañas del cultivo. En ocasiones la incidencia de la enfermedad es tan fuerte que obliga a los agricultores al cambio de la especie cultivada. A nivel mundial, se conocen más de 30 virus que producen enfermedades en el pimiento (Deom et al., 1997). De entre estas enfermedades víricas, aquellas que producen o han producido un mayor 
impacto económico sobre el cultivo del pimiento son las causadas por el virus del bronceado del tomate (Tomato spotted wilt virus, TSWV), el virus del mosaico del pepino (Cucumber mosaic virus, CMV), el virus Y de la patata (Potato virus Y, PVY), el virus del grabado del tabaco (Tobacco etch virus, TEV), el virus del moteado del pimiento (Pepper mottle virus, PepMoV), el virus del mosaico del tomate (Tomato mosaic virus, ToMV) y el virus del moteado suave del pimiento (Pepper mild mottle virus , PMMoV) (Tabla 1.1 y Figura 1.6) (Jordá, 2006). Otros virus de reciente aparición que están produciendo enfermedades de incidencia creciente son el virus del moteado de la parietaria (Parietaria mottle virus, PMoV) y el virus del torrado del tomate (Tomato torrado virus, ToTV) (Janssen et al., 2005) (Amari et al., 2008).
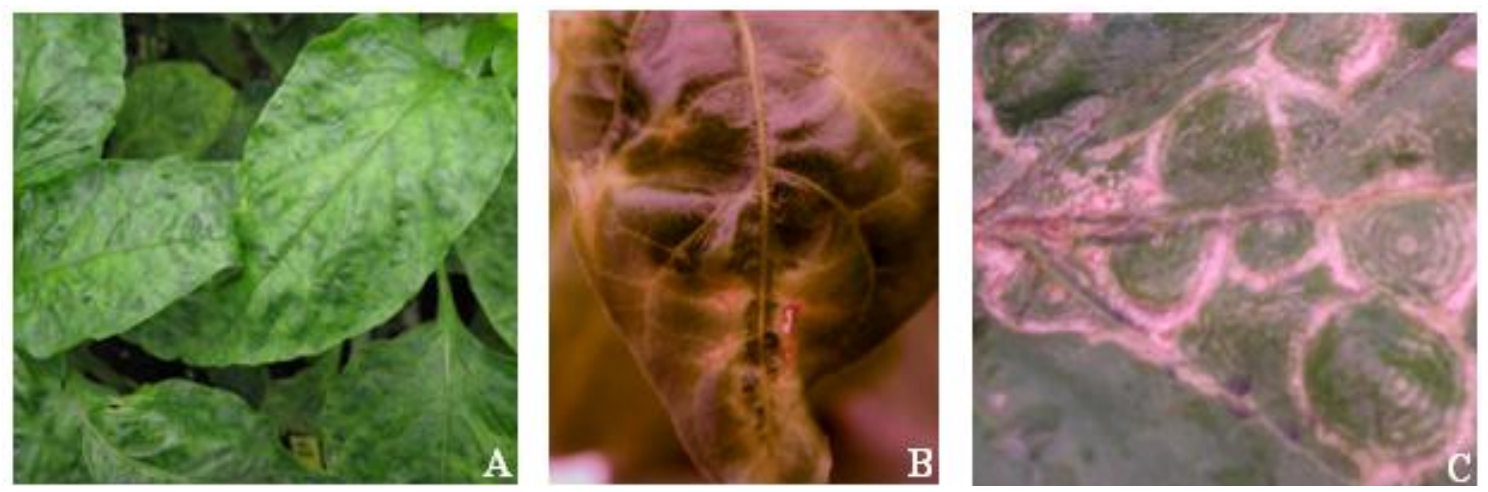

Figura 1.6: Detalle de los síntomas causados por virus que afectan al pimiento. (A) Mosaico y arrugado foliar causado por el Pepper mottle virus (PepMoV), (B) Bandeado oscuro a los lados de las venas causado por el Potato virus Y (PVY), (C) Anillos necróticos en hoja de pimiento producidos por el Tomato spotted wilt virus (TSWV).

En la actualidad, el principal factor limitante del cultivo del pimiento en España es la enfermedad causada por el TSWV. Esto es debido a su amplia gama de hospedantes, la facilidad de dispersión y la limitada eficacia de los productos fitosanitarios para la eliminación completa del vector Frankliniella. Sirva como ejemplo de la incidencia del TSWV, las pérdidas ocasionadas en los cultivos de pimiento para pimentón; uno de los cultivos más tradicionales y emblemáticos de la Región de Murcia. El impacto del TSWV en los años 90 fue tal que obligó a la reestructuración varietal y la aplicación de nuevas técnicas culturales (Costa, 2002). Sin embargo, el TSWV ha provocado una continua disminución de la superficie de pimiento en el campo de Cartagena. Esto, junto al déficit hídrico, ha desplazado el cultivo hacia otros países o zonas de cultivo españolas (Costa, 2002). En la Comarca de La Vera (Extremadura), al contrario de lo que sucede en otras zonas, el TSWV suele pasar desapercibido en la mayoría de 
campañas (Rodríguez et al., 2001), posiblemente porque los inviernos son más duros y las bajas temperaturas pueden limitar el desarrollo del insecto vector.

Tabla 1.1: Virus más importantes del cultivo del pimiento (Nuez et al., 1996).

\begin{tabular}{|c|c|c|c|}
\hline Virus & Género/ Familia & Daños & Vector \\
\hline $\begin{array}{l}\text { Tomato } \\
\text { spotted wilt } \\
\quad \text { virus }\end{array}$ & $\begin{array}{l}\text { Tospovirus/ } \\
\text { Bunyariradae }\end{array}$ & $\begin{array}{l}\text { Produce enanismo, producción nula o escasa. En hojas } \\
\text { aparecen manchas necróticas, a veces en tallo y pecíolo. } \\
\text { En ocasiones necrosis apical y anillos necróticos en } \\
\text { hojas. En frutos además de manchas, la maduración es } \\
\text { irregular y se abullonan los frutos. }\end{array}$ & Trips \\
\hline $\begin{array}{l}\text { PVY } \\
\text { Potato } \\
\text { virus } Y\end{array}$ & $\begin{array}{l}\text { Potyvirus/ } \\
\text { Potyviridae }\end{array}$ & $\begin{array}{l}\text { Aparecen suaves mosaicos foliares en forma de mancha } \\
\text { de color verde claro-verde oscuro. A veces las plantas } \\
\text { presentan manchas necróticas foliares visibles por el haz } \\
\text { y por el envés, extendiéndose en ocasiones por los } \\
\text { pecíolos y tallos. }\end{array}$ & Pulgones \\
\hline $\begin{array}{l}\text { TEV } \\
\text { Tobacco } \\
\text { etch virus }\end{array}$ & $\begin{array}{l}\text { Potyvirus/ } \\
\text { Potyviridae }\end{array}$ & $\begin{array}{l}\text { En las hojas un fuerte jaspeado. Las plantas pueden } \\
\text { presentar una clorosis generalizada, reducción en el } \\
\text { crecimiento y vigor. El aborto de botones florales y } \\
\text { deformaciones del fruto son frecuentes. }\end{array}$ & Pulgones \\
\hline $\begin{array}{l}\text { CMV } \\
\text { Cucumber } \\
\text { mosaic } \\
\text { virus }\end{array}$ & $\begin{array}{l}\text { Cucumovirus/ } \\
\text { Bromoviridae }\end{array}$ & $\begin{array}{l}\text { Existen muchos tipos de síntomas debido a la gran } \\
\text { cantidad de cepas. Las cepas comunes en pimiento } \\
\text { producen mosaicos foliares en forma de marchas de } \\
\text { color verde-claro-amarillento y filimorfismo. Futos } \\
\text { pueden presentar deformaciones, maduración irregular y } \\
\text { manchas de color verde oscuro }\end{array}$ & Pulgones \\
\hline $\begin{array}{l}\text { ToMV } \\
\text { Tomato } \\
\text { mosaic } \\
\text { virus }\end{array}$ & $\begin{array}{l}\text { Tobamovirus/ } \\
\text { Virgaviridae }\end{array}$ & $\begin{array}{l}\text { Las hojas jóvenes presentan un moteado de color verde } \\
\text { claro a amarillo. Puede presentarse un estriado pardo de } \\
\text { tallo y ramas, seguido de necrosis foliar y abcisión de } \\
\text { hojas. En los frutos se observan manchas o moteados } \\
\text { amarillos y arrugamientos. }\end{array}$ & $\begin{array}{l}\text { Mecánica } \\
\text { y por } \\
\text { semillas }\end{array}$ \\
\hline $\begin{array}{l}\text { PepMoV } \\
\text { Pepper } \\
\text { mild mottle } \\
\quad \text { virus }\end{array}$ & $\begin{array}{l}\text { Tobamovirus/ } \\
\text { Virgaviridae }\end{array}$ & $\begin{array}{l}\text { Produce mosaico foliar en forma de manchas verde } \\
\text { oscuro y reducción del crecimiento de la planta. En } \\
\text { frutos reducción del tamaño, abultamientos e áreas } \\
\text { necróticas deprimidas }\end{array}$ & $\begin{array}{l}\text { Mecánica } \\
\text { y por } \\
\text { semillas }\end{array}$ \\
\hline
\end{tabular}

Aunque los medios de lucha indirectos tratan de disminuir el nivel de inoculo existente y/o controlar las poblaciones de insectos vectores, la experiencia acumulada indica que estos métodos no son suficientemente eficaces. Una estrategia eficaz de control de las enfermedades víricas en plantas consiste en la identificación de genes de resistencia, y su posterior utilización para el desarrollo de variedades resistentes. El uso de la resistencia genética como método de lucha se ha visto favorecido al proporcionar una protección efectiva contra un microorganismo determinado, al tener un impacto 
mínimo sobre el medio ambiente y al resultar para el agricultor un método económico y sencillo de estabilizar la producción. Por todo ello, los mejoradores se han esforzado en la búsqueda de fuentes de resistencia a enfermedades causadas por virus, bacterias, hongos y nemátodos. Estas fuentes de resistencia han permitido identificar un gran número de genes de resistencia de carácter dominante o recesivo frente a distintos patógenos virales.

Sin embargo, las ventajas del uso de la resistencia genética para paliar el daño producido por las enfermedades se ven mermadas por la habilidad de los patógenos para evolucionar, superando las resistencias desarrolladas por los mejoradores (Soler y Nuez, 2004). Esto produce una alternancia de ciclos de utilización de la resistencia y la posterior superación de la misma, después de un periodo de tiempo variable (Johnson, 1984; Plank, 1982). Así, la durabilidad de la resistencia puede depender de factores genéticos, ambientales y/o evolutivos. Sin embargo, McDonald y Linde (2002) han propuesto que el potencial evolutivo del patógeno es el factor que determina la estabilidad de una resistencia. Esto implica una necesidad continua de buscar nuevos genes o alelos de resistencia que puedan ser utilizados para contrarrestar la evolución de los patógenos.

La siguiente cuestión es donde buscar las nuevas fuentes de resistencia, es decir materiales que se comporten de forma satisfactoria frente al virus. El proceso de domesticación provocó que las formas cultivadas tengan menos variabilidad genética que las formas silvestres, debido a que sólo una parte de la diversidad presente en el ancestro silvestre pasó a las formas cultivadas. Por tanto, es necesario disponer de suficiente variabilidad genética para la obtención de una nueva variedad hortícola resistente a una enfermedad. La variabilidad utilizada por los mejoradores proviene de diferentes fuentes y una parte importante se encuentra conservada en los bancos de germoplasma. Así, es muy importante tener acceso a colecciones de recursos fitogenéticos relacionados con la especie hortícola a mejorar, en nuestro caso los pimientos. 


\subsection{La importancia de los recursos fitogenéticos para el desarrollo de nuevos cultivares}

Los recursos fitogenéticos constituyen el material necesario e inicial para el desarrollo de nuevos cultivares, y para la identificación de nuevas fuentes de resistencia. La cruzabilidad y la proximidad genética del recurso con la variedad a mejorar son aspectos a considerar. Siempre debe empezarse ensayando el comportamiento de variedades pertenecientes a la especie cultivada, para evitar la introducción de genoma no deseable. Sin embargo, el estrechamiento de la base genética de las especies cultivadas dificulta la identificación de nuevas fuentes de resistencia. Así, es necesario recurrir a las especies silvestres relacionadas evolutivamente o, incluso en algunos casos, a géneros relacionados. Esta variabilidad exógena puede en algunos casos incorporarse mediante hibridación directa con la especie cultivada. Si la especie silvestre y la cultivada están bastante alejadas genéticamente y el cruce directo es inviable, se pueden utilizar distintas técnicas para conseguir la introgresión de la resistencia. Por ejemplo, cruces previos con una especie más próxima a las dos (especie puente) o el rescate in vitro de embriones. Se ha comprobado repetidamente que las especies silvestres presentan mayores niveles de resistencia que las especies domesticadas relacionadas (Rosenthal y Dirzo, 1997). Las continuas selecciones acumularon en las plantas cultivadas una gran cantidad de cambios beneficiosos para los humanos. Sin embargo, se generó la disminución o pérdida de otros factores, como las substancias tóxicas o características morfológicas que servían de defensa (Pérez de la Vega, 2010). De esta forma, puede entenderse el porqué la búsqueda de genes de resistencia en los progenitores silvestres es tan frecuente, y el porqué la mayoría de cultivares modernos contienen genes que proceden de alguna especie silvestre relacionada (Hajjar y Hodgkin, 2007).

Es razonable suponer que la enfermedad que afecta a las variedades cultivas también atacará a las especies silvestres relacionadas. Por tanto debido a la evolución planta/patógeno, es probable que en la zona geográfica de la especie silvestre exista variación para la resistencia de la planta y para la capacidad de infección del patógeno (García, 2004). Esto hace que la variabilidad genética de los centros de origen de las plantas cultivadas constituya un recurso prioritario en la búsqueda de este tipo de genes, cuando la especie patógena y vegetal han coexistido. No obstante, aunque no hayan 
evolucionado conjuntamente, la elevada variabilidad neutra de estos centros podría ser también útil para la detección de nuevas resistencias. Por todo ello, estos centros son una fuente de recursos fitogenéticos potencialmente útiles para la mejora genética de las especies cultivadas.

El área nuclear de las especies del género Capsicum probablemente son las tierras de Bolivia, con la consiguiente migración a los Andes (Perú) y a las tierras bajas de las Amazonía (Mc Leod et al., 1982). Una fracción importante de esta variabilidad se encuentra actualmente conservada en bancos de germoplasma. Existen colecciones de germoplasma del género Capsicum de reconocida importancia mantenidas en distintos centros; el National Plant Germplasm System (NPGS) de Estados Unidos, el N.I. Vavilov Research Institute of Plant Industry (VIR) de Rusia, el Centre for Genetic Resources (CGN) de Holanda y el Banco de Germoplasma del Instituto de Conservación y Mejora de la Agrodiversidad Valenciana (COMAV) de España. Este último dispone de una colección de 2.477 entradas de las distintas especies domesticadas del género Capsicum.

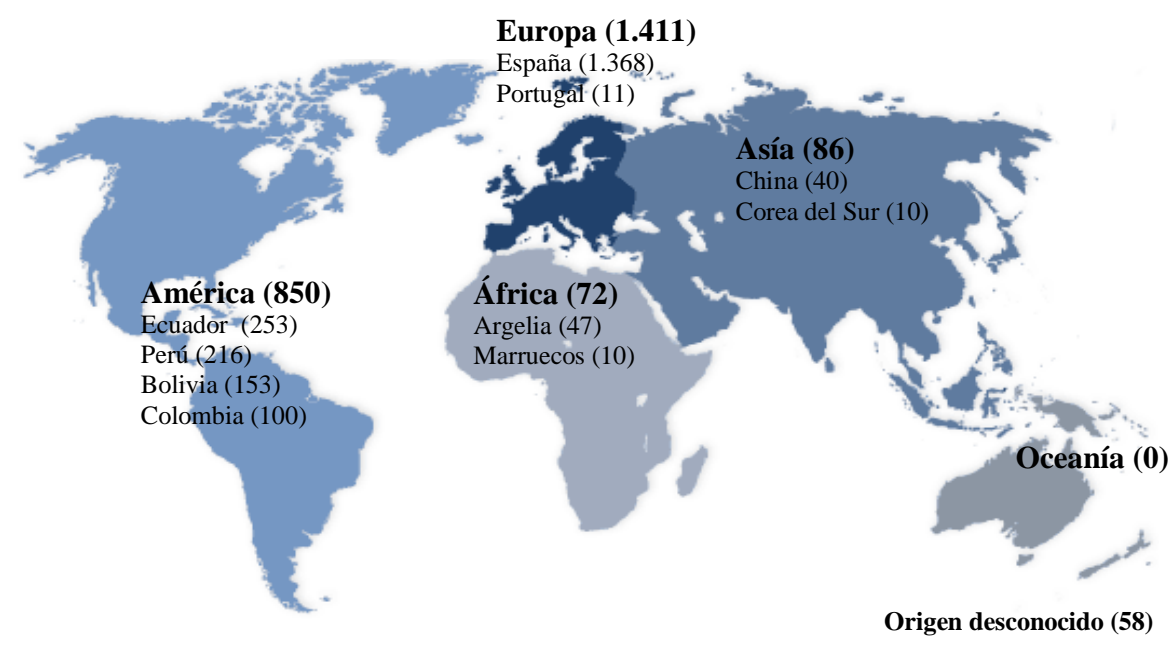

Figura 1.7: Distribución mundial de las 2.477 entradas del género Capsicum del COMAV (cortesía del Banco de Germoplasma del COMAV).

\subsubsection{Especies cultivadas del género Capsicum}

Capsicum es un pequeño género que incluye 27 especies de gran importancia económica. Este género nativo del Nuevo Mundo forma parte de la extensa familia de 
las solanáceas. Esta contiene 18 géneros entre los que se incluyen especies cultivadas muy importantes: Solanum, Cyphomandra, Nicotiana o Physalis (Hunziker, 1979).

La taxonomía dentro del género Capsicum es compleja, debido a la gran variabilidad de formas existentes en las especies cultivadas y a la diversidad de criterios utilizados en la clasificación. La morfología floral (color de la flor, número de flores por axila, color de la corola, color de las anteras), caracteres como la presencia o ausencia de la constricción anular o la forma del margen del cáliz de los frutos son los descriptores más utilizados en la identificación de estas especies. El género está dividido en tres secciones, Tubocapsicum, Pseudoacnistus, con una especie cada una, y Capsicum. La sección Capsicum incluye 22 especies silvestres y 5 especies domesticadas por los nativos americanos (C. annuum var. annuum, $C$. chinense, $C$. frutescens, C. baccatum var. pendulum y umbilicatum, y C. pubescens) (Figura 1.7).

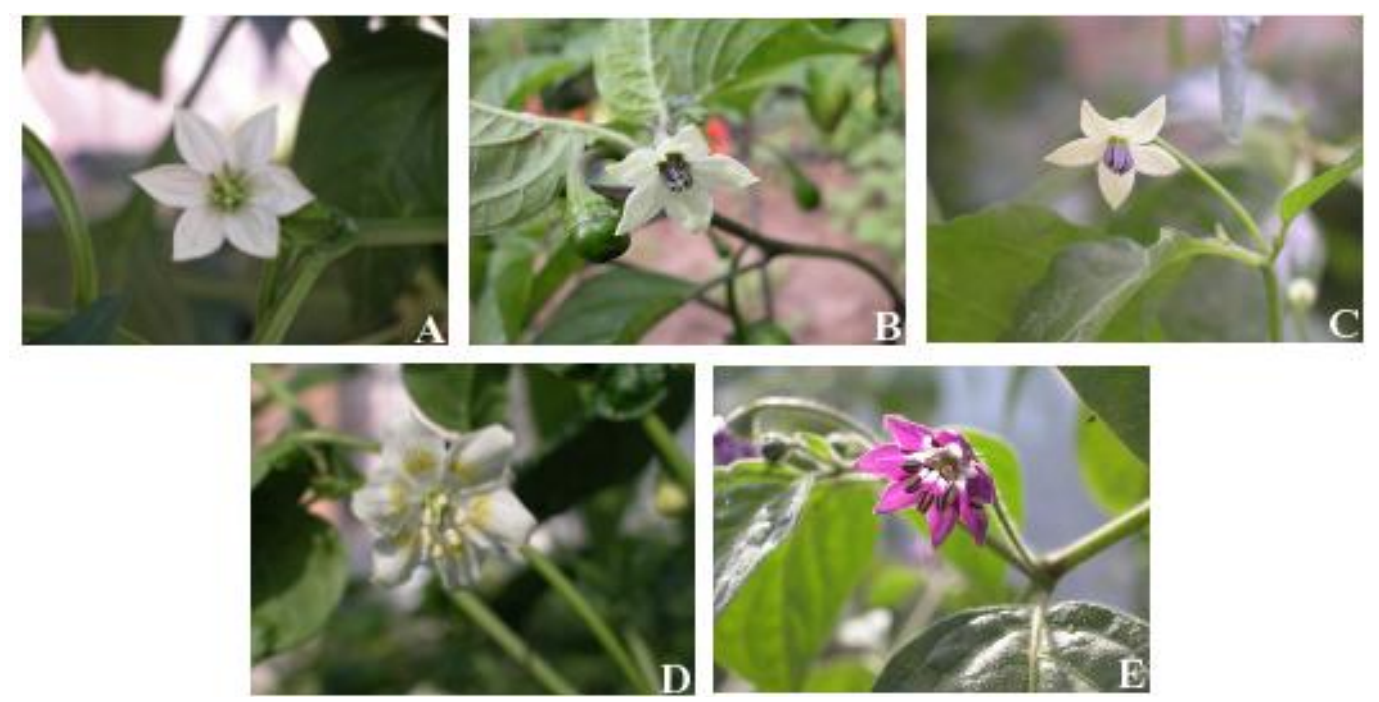

Figura 1.8: Detalle de la flor de las especies domesticadas del género Capsicum. (A) C. annuиm, (B) C. chinense, (C) C. frutescens, (D) C. baccatum y (E) C. pubescens (cortesía del Banco de Germoplasma del COMAV).

Las especies domesticadas del pimiento son cultivadas alrededor del mundo, excepto $C$. pubescens que es cultivada únicamente en las tierras altas de la Región Andina (Nuez et al., 1996). Las variedades no picantes de C. annuum son las más consumidas en occidente. Estas son el principal objetivo de la mayoría de los programas de mejora y estudios genéticos (Nuez et al., 1996). Sin embargo, $C$. chinense, $C$. frutescens, C. baccatum y C. pubescens además de su explotación comercial, son buenos recursos genéticos para la mejora de C. annuum. Por tanto, dada la importancia 
de estas especies en caracteres relacionados con la resistencia a enfermedades (Polston et al., 2006), plagas (Fery y Thies, 1997), tolerancia al frío (De Swart, 2007) o calidad nutricional (Zewdie y Bosland, 2000), es necesario para evaluar su posible uso en la mejora, conocer las relaciones de cruzabilidad existentes entre ellas y entre las especies silvestres.

\subsubsection{Relaciones de cruzabilidad entre las especies cultivadas}

Las especies del género Capsicum han sido divididas en tres complejos según las características morfológicas, el número de cromosomas y los estudios de hibridación. $C$. annuum, $C$. chinense y $C$. frutescens forman el complejo $C$. annuum junto a sus formas silvestres y la especie silvestre endémica de las Islas Galápagos, Capsicum galapagoensis L. Estas especies cruzan con facilidad (Onus y Pickersgill, 2004). De hecho, varios investigadores argumentaron que $C$. chinense y $C$. frutescens deberían ser una única especie porque cruzan fácilmente y están integradas en un continuo morfológico (McLeod et al., 1979a, Pickersgrill, 1971; Walsh y Hoot, 2001). Un segundo grupo está formado por el complejo $C$. baccatum. Este incluye esta especie cultivada y la silvestre Capsicum praetermissum H. \& P. Por otra parte, C. pubescens, junto $C$. cardenasii y $C$. eximium forman el complejo $C$. pubescens. Las estrechas relaciones entre estas tres especies con flores de color púrpura fueron apoyadas mediante cruzamientos (Pickersgill, 1991). Las especies silvestres $C$. eximium y $C$. cardenasii son morfológicamente distintas. Sin embargo, pueden formar híbridos naturales entre ellas que son más fértiles que algunos cruces entre variedades de la misma especie (Eshbaugh, 1976; McLeod et al., 1979b). A partir de datos moleculares, estas dos especies fueron indistinguibles (Choong, 1998; Ryzhova y Kochieva, 2004). En Capsicum, a diferencia de otros géneros de la familia Solanaceae como Solanum y Nicotiana, muchas de las especies son autocompatibles. La única especie autoincompatible es C. cardenasii (Onus y Pickersgill 2004).

El hombre ha tratado de mejorar la producción y la calidad de las variedades de pimiento con el cruce de las diferentes especies del género Capsicum. Así, a pesar de la separación en complejos, se han obtenido diferentes cruzamientos interespecíficos (De Swart, 2007). Aunque $C$. annиum у $C$. baccatum pertenecen a diferentes complejos, varios ensayos se han llevado a cabo para la obtención de protocolos que permitan el 
desarrollo de híbridos viables. El AVRDC (Asian Vegetable Research and Development Center) informó de líneas de la especie $C$. annuum parcialmente compatibles con $C$. baccatum (AVRDC, 1999). En el año 2006, investigadores coreanos obtuvieron plantas híbridas pero estériles (Yoon et al., 2006). Sin embargo, la esterilidad de los híbridos se superó mediante un retrocruzamiento intensivo, utilizando $C$. annuиm como el parental donante de polen (Yoon et al., 2006). En otros ensayos se utilizó $C$. chinense como especie puente para superar las incompatibilidades entre $C$. annиит у C. baccatum (Yoon y Park, 2005). C. pubescens no cruza con las otras cuatro especies (Smith et al., 1987). No obstante, se han mencionado diferentes métodos para obtener los cruzamientos entre los complejos de $C$. pubescens y $C$. annuиm. Zijlstra et al. sugirieron que la especie silvestre Capsicum chacoense $\mathrm{H}$. puede ser útil como especie puente para superar esta incompatibilidad (Zijlstra et al., 1991). Además Molchova y Michailova (1982) fueron capaces de cruzar plantas de estas dos especies mediante una entrada tetraploide de $C$. апnиum. Por último, Pickersgill especuló que la incompatibilidad podría ser superada mediante el rescate de embriones (Pickersgill, 1988). Todos estos esfuerzos en romper estas barreras de cruzabilidad, se realizan al ser la hibridación interespecífica esencial para la introgresión de genes de interés que mejoren la producción, la calidad y la tolerancia a estreses abióticos de las variedades o la morfología de la planta (Crosby, 2008). Además, se han introgresado exitosamente en C. annuиm genes relacionados con la resistencia a enfermedades del pimiento e identificados en especies del género Capsicum (Crosby, 2008). Por ejemplo, el gen $L$ involucrado en la resistencia al virus del mosaico del tabaco (Boukema, 1980) se ha introgresado en variedades modernas de $C$. annuum, desde $C$. frutescens, $C$. chinense y C. chacoense. La resistencia al hongo Leveillula taurica, identificada en C. chinense, se ha transferido al cultivar jalapeño de C. annuum (Crosby, 2008).

\subsubsection{Aprovechamiento de la variabilidad genética conservada en los bancos de germoplasma}

Previamente, se ha comentado que la agricultura actual se basa en el cultivo de un número muy limitado de especies con un nivel de diversidad genética reducido, respecto las especies silvestres de las que proceden. Este estrechamiento de la base genética de las especies cultivadas es un proceso irreversible, ya que la variabilidad perdida no se puede recuperar. Sin embargo, en la actualidad es necesario e imprescindible obtener 
nuevas variedades más productivas y adaptadas. Por una parte ello permitirá seguir alimentando la población mundial, y por otra se prevendrán los problemas generados por los factores abióticos y bióticos (Martín, 2001). Esto sólo es posible si se dispone de una reserva de variación genética para poder seleccionar las plantas con los caracteres deseados. Una parte importante de la variabilidad se encuentra actualmente conservada en bancos de germoplasma, pero para su correcta utilización es necesario cuantificar y analizar la variabilidad interespecífica e intraespecífica disponible.

La diversidad genética existente y su partición dentro y entre individuos, poblaciones y especies, es fundamental para la correcta gestión y utilización eficiente de los recursos fitogenéticos en los programas de mejora (Pérez de la Vega y García, 2000). El conocimiento de la cantidad y la distribución de la variabilidad deben ser tenidos en cuenta al establecer las prioridades de recolección y conservación de los recursos genéticos, al promover la multiplicación eficiente de las colecciones de germoplasma, así como en la creación de colecciones nucleares (Pérez de la Vega y García, 2000). Además, la conservación y la preservación de la diversidad es muy útil para evitar la erosión genética de los cultivos. Por otra parte, la información de los estudios biosistemáticos puede ser de gran importancia para maximizar el potencial de los programas de mejora (Allard, 1960). La identificación y clasificación de los recursos genéticos, o la determinación de sus relaciones con las plantas domesticadas, ayuda a los mejoradores a elegir los materiales más relevantes y útiles para sus programas de mejora (Prohens et al., 2003). En el caso del género Capsicum, el estudio de la diversidad y las relaciones de las especies tiene una gran importancia agronómica. $C$. chinense, $C$. frutescens, $C$. baccatum y $C$. pubescens son fuentes potenciales para utilizar en la mejora de C. annuum (Fery y Thies, 1997; Zewdie y Bosland, 2000). Por tanto, es necesario desarrollar estrategias para proporcionar información acerca de la diversidad genética y las relaciones filogenéticas de las especies domesticadas de pimiento.

Antiguamente, la determinación de la variabilidad genética se llevaba a cabo de manera indirecta, analizando la variación de caracteres morfológicos y agronómicos (Viruel, 2010). La precisión estaba limitada por el reducido número de caracteres discriminantes, muchas veces poco variables, y por la influencia del ambiente en su expresión (Karp et al., 1997; Ince et al., 2010). La incorporación de marcadores 
bioquímicos (isoenzimas) eliminó el efecto del medio ambiente, pero los niveles de variación genética que detectaban eran insuficientes (Viruel, 2010). Los avances en la genética molecular permitieron el desarrollo de los marcadores moleculares basados en los polimorfismos de ADN. Estos eliminaron los inconvenientes de los marcadores anteriores y mejoraron la evaluación de la diversidad genética dentro y entre las especies, y la selección de germoplasma. Los marcadores moleculares más utilizados son los AFLPs (Amplified Fragment Length Polymorphisms) y los SSRs (Simple Sequence Repeats) (Viruel, 2010). Los microsatelites (SSRs) son codominantes, polimórficos, reproducibles, están distribuidos uniformemente por todo el genoma y la interpretación de los resultados es más sencilla que con los AFLPs (Russell et al., 1997). Por ello, los SSRs representan una mejora sustancial de calidad con respecto a los AFLPs. Sin embargo, estos últimos generan un elevado nivel de polimorfismo en las solanáceas (Furini y Wunder, 2004; Spooner et al., 2005; Blanca et al., 2007), y a diferencia de los microsatélites no se necesita de información previa de las secuencias para ser diseñados. Los microsatélites permiten una mejor diferenciación genética intraespecífica al presentar mayores tasas de mutaciones (Li et al., 2004). Por otro lado, los AFLPs son una herramienta eficaz para determinar las relaciones genéticas entre las especies estudiadas (Furini y Wunder, 2004; Zuriaga et al., 2009a).

Los marcadores moleculares se han utilizado en el género Capsicum por diferentes grupos de investigación (Rodríguez et al., 1999; Lefebvre et al., 2001; Tam et al., 2009; Ince et al., 2010). Estos han permitido sobre todo una mejor asignación taxonómica de las entradas, la identificación de entradas duplicadas en los bancos de germoplasma o el análisis de la diversidad de C. annuиm (Geleta et al., 2005; Hanacek et al., 2009). Otros estudios analizaron la diversidad genética de distintas especies del género Capsicum en zonas muy concretas. Por ejemplo, en el Departamento de Amazonas (Colombia) y en el Departamento de Alta Verapaz (Guatemala) (Toquica et al., 2003; Guzman et al., 2005). Sin embargo, la distribución de la variabilidad genética a nivel molecular dentro de $C$. chinense, $C$. frutescens, $C$. baccatum y $C$. pubescens no ha sido muy estudiada, al estar representada cada especie con un pequeño número de entradas. Por ello, un estudio con una buena representación de entradas es necesario, al ser la variación intraespecífica especialmente importante para el estudio de la variación entre las especies y las relaciones genéticas entre estas (Zuriaga et al., 2009a). 


\subsubsection{Fuentes de resistencia a patógenos identificadas en Capsicum}

Durante las últimas décadas, las ventajas del uso de la resistencia genética para paliar el daño producido por las enfermedades en pimiento, han incentivado la búsqueda de nuevas fuentes de resistencia a hongos, bacterias y nemátodos. Siempre a partir de los recursos fitogenéticos disponibles. En el caso del pimiento, se han desarrollado cultivares resistentes a hongos como Phytophtora capsici (Walker y Bosland, 1999) o Colletotrichum capsici (Qing-Lin et al., 2002), a nematodos como Meloidogyne incognita (Hendy et al., 1985) o M. arenaria (Djian-Caporalino et al., 2001) y a bacterias como Xanthomonas campestris (Jones et al., 2002). Sin embargo, actualmente los mejoradores se han centrado en la resistencia a enfermedades virales, al constituir los principales factores limitantes de la producción del pimiento, y porque el desarrollo de variedades resistentes es el método de lucha más eficaz contra estas enfermedades (Tabla 1.2).

En muchas ocasiones, la resistencia conferida por estos genes depende de la presencia en la planta de un gen de resistencia dominante $\mathrm{R}$ (Resistance gene), el producto del cual está implicado en el reconocimiento del producto de un gen específico de avirulencia (Avr) del patógeno. Una pérdida o alteración de los dos genes afectará a este reconocimiento e inducirá la enfermedad. Así, la resistencia que proveen los genes $\mathrm{R}$ puede verse rápidamente superada por la capacidad de mutación del patógeno en los genes Avr, escapando de esta manera al reconocimiento. Este es el denominado sistema gen a gen (Flor, 1947, 1971). Además, la presencia de aislados o razas en los distintos virus que afectan a las plantas, favorece la susceptibilidad de las plantas con genes de resistencia $\mathrm{R}$ al permitir la multiplicación de algunas de las cepas virales. Sin embargo, en algunos casos la resistencia a enfermedades es de tipo recesivo, la cual no puede ser explicada mediante el modelo de los genes R. Según Fraser, las respuestas de resistencia recesivas son debidas a la falta o a la mutación en un gen, el cual codifica para un factor de la planta necesario para que el patógeno complete su ciclo vital (Fraser, 1990). Los virus necesitan de la maquinaria bioquímica de la planta para completar su ciclo biológico. Distintos estudios han demostrado que algunos factores del hospedante tienen una importante función en la traducción y replicación del ARN de distintos virus (Morales, 2005; Ahlquist et al., 2003; Noueiry et al., 2000; Tsujimoto et al., 2003). Sin embargo, la mutación en uno de los genes que codifica para estos factores del 
hospedante, necesarios para el virus, puede generar resistencia. Las resistencias recesivas son más frecuentes frente a virus de plantas que frente a otros patógenos, donde predominan los genes R. La respuesta resistente generada por un gen recesivo posee la ventaja de ser más estable frente al carácter cambiante de los patógenos virales (Fraser, 1990, 1992). Esto es debido al hecho de que el virus para superar la resistencia debe ser capaz de generar una nueva función, la cual restablezca la interacción con la maquinaria celular de la planta.

Tabla 1.2: Genes de resistencia a enfermedades de etiología viral en pimiento.

\begin{tabular}{|c|c|c|c|c|}
\hline Patógeno viral $^{1}$ & $\begin{array}{l}\text { Fuente de } \\
\text { resistencia }\end{array}$ & $\begin{array}{l}\text { Alelo de } \\
\text { resistencia }\end{array}$ & $\begin{array}{l}\text { Control } \\
\text { genético }^{2}\end{array}$ & Referencias \\
\hline CMV & C. аппиит & $\mathrm{cm}$ & $\mathrm{M}, \mathrm{r}$ & Singh et al., 1977 \\
\hline ChivMV & C. аппиит & $p v r 2^{2}+p v r 6$ & Di, r & Hwang et al., 2009 \\
\hline $\mathrm{LCV}$ & C. аппиит & $l c$ & $\mathrm{M}, \mathrm{r}$ & Singh et al., 1977 \\
\hline TMV/ToMV & C. аппиит & $L 1$ & M, D & Boukema et al., 1980 \\
\hline TMV/ToMV & C. frutescens & $L 2$ & M, D & Boukema, 1980 \\
\hline TMV/ToMV/PMMoV & C. chinense & $L 3$ & M, ID & $\begin{array}{l}\text { Boukema, 1980; Berkmortel, } \\
\text { 1977; Betti et al., } 1986\end{array}$ \\
\hline TMV/ToMV/PMMoV & C. chacoense & $L 4$ & M, D & $\begin{array}{l}\text { Boukema, 1984; Matsunaga et al., } \\
2003\end{array}$ \\
\hline PVY/PepMoV/TEV & C. chinense & $p v r 1$ & $\mathrm{M}, \mathrm{r}$ & $\begin{array}{l}\text { Kyle y Palloix, 1997; Murphy et } \\
\text { al., } 1998\end{array}$ \\
\hline PVY/PepMoV & C. аппиит & Pvr4 & M, D & $\begin{array}{l}\text { Dogimont et al., 1996; Caranta et } \\
\text { al., } 1999\end{array}$ \\
\hline PVY & C. аппиит & $p v r 2^{1}$ & $\mathrm{M}, \mathrm{r}$ & $\begin{array}{l}\text { Ruffel et al., 2002; Kang et al., } \\
2005\end{array}$ \\
\hline $\mathrm{PVY} / \mathrm{TEV}$ & C. апnиum & $p v r 2^{2}$ & $\mathrm{M}, \mathrm{r}$ & $\begin{array}{l}\text { Kang et al., 2005; Charron et al., } \\
2008\end{array}$ \\
\hline PVY & C. аппиит & $p v r 2^{3}$ & $\mathrm{M}, \mathrm{r}$ & Charron et al., 2008 \\
\hline PVY & C. аппиит & $p v r 2^{4}$ & $\mathrm{M}, \mathrm{r}$ & Charron et al., 2008 \\
\hline PVY & C. аппиит & $p v r 2^{5}$ & $\mathrm{M}, \mathrm{r}$ & Charron et al., 2008 \\
\hline PVY & C. аппиит & $p v r 2^{6}$ & $\mathrm{M}, \mathrm{r}$ & Charron et al., 2008 \\
\hline PVY & C. аппиит & $p v r 2^{7}$ & $\mathrm{M}, \mathrm{r}$ & Charron et al., 2008 \\
\hline PVY & C. аппиит & $p v r 2^{8}$ & $\mathrm{M}, \mathrm{r}$ & Charron et al., 2008 \\
\hline PVY & C. аппиит & $p v r 2^{9}$ & $\mathrm{M}, \mathrm{r}$ & Charron et al., 2008 \\
\hline PepMoV & C. chinense & $P v r 7$ & M, D & Grube et al., 2000 \\
\hline PVMV & C. аппиит & $p v r 2^{2}+p v r 6$ & $\mathrm{Di}, \mathrm{r}$ & Ruffel et al., 2006 \\
\hline TSWV & C. chinense & $T s w$ & M, D & Jahn et al., 2000 \\
\hline
\end{tabular}

${ }^{1}$ CMV (Cucumber mosaic virus); ChiVMV (Chilli veinal mottle virus); LCV (Leaf curl virus); TMV (Tobacco mosaic virus); ToMV (Tomato mosaic virus); PMMoV (Pepper Mild Mottle Virus); PVY (Potato virus Y); PepMoV (Pepper mottle virus); PVMV (Pepper veinal mottle virus); TSWV (Tomato spotted wilt virus).

${ }^{2} \mathrm{M}$ (monogénico); Di (digénico); D (dominante); ID (dominancia intermedia); r (recesivo). 


\subsubsection{Los factores de iniciación a la traducción como responsables de resistencias a virus}

La clonación de varios genes, responsables de resistencias recesivas a virus en diversas plantas, ha demostrado que codifican para los factores de iniciación a la traducción del complejo 4F. Este está formado por dos subunidades: eIF4E y eIF4G. En plantas se ha identificado una isoforma del eIF4F, eIF(iso)4F, la cual está constituida por las subunidades eIF(iso)4E y eIF(iso)4G (Browning et al., 1992). Los complejos 4F tiene un papel esencial en los pasos iniciales de la traducción del ARNm de los organismos eucariotas (Browning, 1996; Gingras et al., 1999). En estos, los ARNm presentan en el extremo 5' el casquete de metil guanina (cap) y en el extremo 3' la cola poly(A). Estas estructuras interaccionan con los factores durante las primeras etapas de la traducción (Sachs y Varani, 2000). Los virus requieren de la maquinaria transcripcional del hospedante para poder traducir su material genético e infectar a la planta. Por tanto, los factores de iniciación a la traducción están implicados en la síntesis de las proteínas virales, y las mutaciones pueden impedir la síntesis proteica viral. Por ejemplo, los alelos de $C$. annuum ( $p v r 2), C$. chinense ( $p v r 1)$ y Solanum habrochaites K. \& S. (pot-1) que confieren resistencia al virus Y de la patata (PVY) y al virus del grabado del tabaco (TEV), codifican para el factor de iniciación a la traducción 4E, eIF4E (Ruffel et al., 2002; Kang et al., 2005; Ruffel et al., 2005). Otros alelos mutantes del gen eIF4E bloquean la multiplicación de otros miembros de la familia Potyviridae en diferentes cultivos: lechuga (Nicaise et al., 2003), guisante (Gao et al., 2004, Bruun-Rasmussen et al., 2007), sandía (Ling et al., 2009), cebada (Kanyuka et al., 2005) y en el frijol común (Naderpour et al., 2010). Otro ejemplo de resistencia a Potyvirus son los alelos $l s p 1^{1}$ y $l s p l^{2}$ de Arabidopsis thaliana L., los cuales codifican para la isoforma $e I F(i s o) 4 E$, esencial para la replicación del virus del mosaico del nabo (Turnip mosaic virus, TuMV) (Lellis et al., 2002). También hay ejemplos de mutaciones en eIF4E, eIF4G y eIF(iso)4G que confieren resistencia a otras familias de virus en diferentes especies (Truniger y Aranda, 2009). Así, un alelo del gen nsv que codifica para eIF4E en melón (Cucumis melo L.) inhibe la multiplicación del virus de las manchas necróticas del melón (Melon necrotic spot virus, MNSV) (Tombusviridae) (Nieto et al., 2007). Los alelos cum1 y cum 2 de A. thaliana que codifican para eIF4E y eIF4G inhiben la propagación del virus del mosaico del pepino (Cucumber mosaic virus, CMV) (Bromoviridae) (Yoshii et al., 2004). Por último, en arroz se han descrito 
varias mutaciones en el factor eIF(iso)4G (Oryza sativa L.) que confieren resistencia al virus del moteado amarillo del arroz (Rice yellow mottle virus, RYMV) (Sobemovirus) (Albar et al., 2006). Todos estos datos indican que la interacción entre los factores de iniciación de la traducción de la planta y el ARN viral es necesaria para la replicación y la infección viral (Robaglia y Caranta, 2006; Dreher y Miller, 2006). Los estudios han demostrado que la interacción entre factores de iniciación y la proteína viral VPg es necesaria para completar el ciclo infeccioso del virus (Leonard et al., 2000; Schaad et al., 2000), mientras que los factores de iniciación relacionados con la resistencia alteran esta unión con VPg (Kang et al., 2005; Charron et al., 2008). Por tanto, es evidente que ciertas mutaciones en los factores de iniciación de la traducción (eIF4E, eIF(iso)4E, eIF4G y eIF(iso)4G) rompen el ciclo del virus. Sin embargo, estas mutaciones no afectan a las funciones biológicas de la planta (Yoshii et al., 2004). Por todo ello, estos genes son candidatos potenciales en la búsqueda de nuevas fuentes de resistencia frente a los virus de estas y otras familias que afecten al género Capsicum, y en la identificación de alelos de resistencia para combatir eficazmente la aparición de nuevas cepas que rompan la resistencia.

\subsection{Aproximación metodológica en la identificación de fuentes de resistencia a virosis}

El desarrollo de nuevas variedades con resistencia genética es la alternativa elegida para el control de las enfermedades víricas. Un problema que presenta esta estrategia es la identificación de entradas con resistencia al patógeno, la identificación del locus responsable y la posterior incorporación de los genes de interés a variedades comerciales. Aunque la evaluación del germoplasma para resistencia a enfermedades puede realizarse en campo en aquellas zonas donde la enfermedad aparece de manera natural debido a la presencia continuada del patógeno (García, 2004), las variaciones temporales en las poblaciones de los patógenos y en las condiciones ambientales hacen preferible la búsqueda de resistencia en condiciones controladas y reproducibles. Se puede así controlar el estado de desarrollo de la planta, las condiciones ambientales de crecimiento, la cepa del patógeno a utilizar (de una zona concreta o la más agresiva) y la concentración del inoculo, según se busca resistencia total o si se desea cuantificar el grado de resistencia (García, 2004). 
Una de las claves para el éxito en la identificación de nuevas fuentes de resistencia en las colecciones radica en la selección de las entradas para ser evaluadas. El Instituto de Conservación y Mejora de la Agrodiversidad Valenciana (COMAV) de la Universidad Politécnica de Valencia (UPV) dispone de una gran colección de entradas de $C$. annuum, C. chinense, $C$. frutescens, $C$. baccatum y $C$. pubescens, procedentes de distintos países. Distintos cribados, con un elevado número de plantas, han permitido la identificación de resistencias frente al TSWV (Cebolla-Cornejo et al., 2003) o ToMV. Estas búsquedas se realizaron a partir de la metodología convencional utilizada habitualmente para la identificación de fuentes de resistencia a virosis.

\subsubsection{La metodología convencional basada en la caracterización fenotípica}

En la búsqueda de nuevas fuentes de resistencia en colecciones de germoplasma, es necesario invertir grandes cantidades de trabajo, tiempo y dinero durante las labores de inoculación con el patógeno (Figura 1.8), en la posterior evaluación de los síntomas y de la presencia del patógeno. A modo de ejemplo, en la realización de un test de patogenicidad suelen utilizarse unas 20 plantas por entrada para tener suficiente información fiable

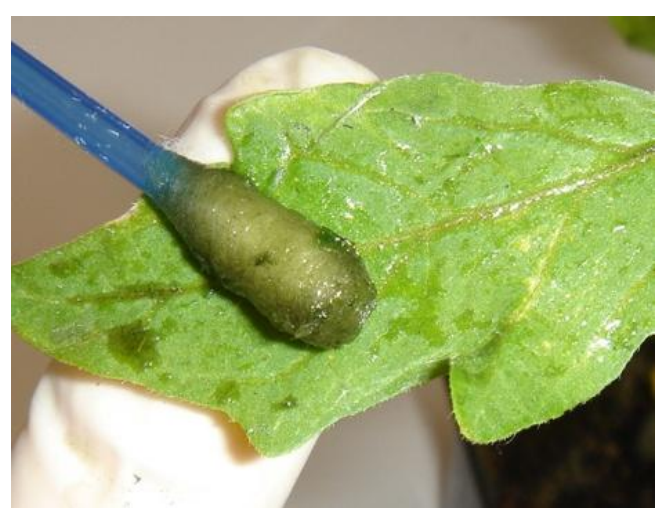

Figura 1.9: Inoculación mecánica del PVY en tomate. respecto la respuesta de la entrada. Tras la inoculación mecánica del virus sobre las plantas, los síntomas de cada planta son anotados a los 15, 30, 45 y 60 días después de la inoculación (DDI). A la vez que el análisis de síntomas, se toma de cada planta una muestra de hojas apicales para detectar la presencia o ausencia del virus mediante la técnica DAS-ELISA (Double-Antibody Sandwich Enzyme Linked Immunosorbent Assay) (Figura 1.9) u otras tecnologías. Por tanto, el fenotipado de todas las entradas o aquellas que representarían la diversidad de una especie requiere de un gran esfuerzo que dificulta la detección de resistencias. Además, en muchas ocasiones sin garantías de éxito, ya que depende de la existencia del fenotipo buscado. Por otra parte, las resistencias identificadas suelen ser frente a un estrecho rango de razas del organismo y su validez suele ser breve debido a la evolución huésped/patógeno. Esto supone un gran reto e implica la necesidad continua en buscar nuevas fuentes de resistencia para las 
enfermedades. Por tanto, disponer de una estrategia capaz de disminuir los costes asociados al proceso de fenotipado sería muy ventajoso, al poder reducir la caracterización de la resistencia a un virus en las entradas de las colecciones de germoplasma.

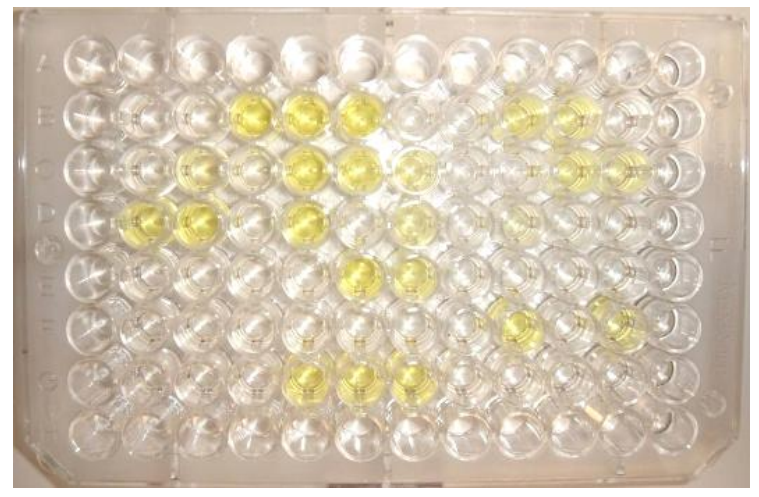

Figura 1.10: Detalle de una placa tras realizar la prueba DAS-ELISA con anticuerpos contra el PVY.

\subsubsection{Nuevas aproximaciones biotecnológicas para el rastreo de colecciones de germoplasma}

Diferentes estrategias se han desarrollado para favorecer la identificación de las entradas que contienen caracteres de interés. Una de ellas es la técnica TILLING (Target Induced Local Lesions in Genomes) que genera variantes alélicas de genes mediante mutagénesis artifical, y posteriormente las identifica (Till et al., 2003). Por analogía y uso de los mismos principios se definió la técnica EcoTILLING como la aplicación de la técnica TILLING a una población natural o mejorada para identificar de forma rápida mutaciones naturales en un gen candidato (Comai et al., 2004). Estas técnicas están basadas en el empleo de las endonucleasas de cadena simple CEL I (Till et al., 2004) o ENDO1 (Triques et al., 2008). Las técnicas se basan en que los fragmentos amplificados del gen candidato de la muestra problema son desnaturalizados y renaturalizados frente a una muestra control para formar duplexes. Si las cadenas de ADN son diferentes, no habrá complementariedad total y se formarán heteroduplex con errores de apareamiento (mismatch) (Figura 1.10). Estos son reconocidos por la enzima y digeridos, de manera que la actividad enzimática es aprovechada para detectar las posiciones donde existan polimorfismos. Tras la digestión de los heteroduplex se dará lugar a fragmentos de distinto tamaño que generarán un patrón de bandas, visualizado en un gel de acrilamida. Esto indicará que las secuencias que se están comparando son 
diferentes y constituyen alelos distintos. Alternativamente si se mezclan dos cadenas totalmente idénticas se formarán únicamente homoduplex que no serán digeridos por la enzima. De esta forma, la técnica EcoTILLING permite comparar secuencias nucleotídicas de un gen e identificar diferentes alelos en una colección de germoplasma. En número de alelos identificados dependerá de los patrones de bandas presentes en la plataforma de EcoTILLING.

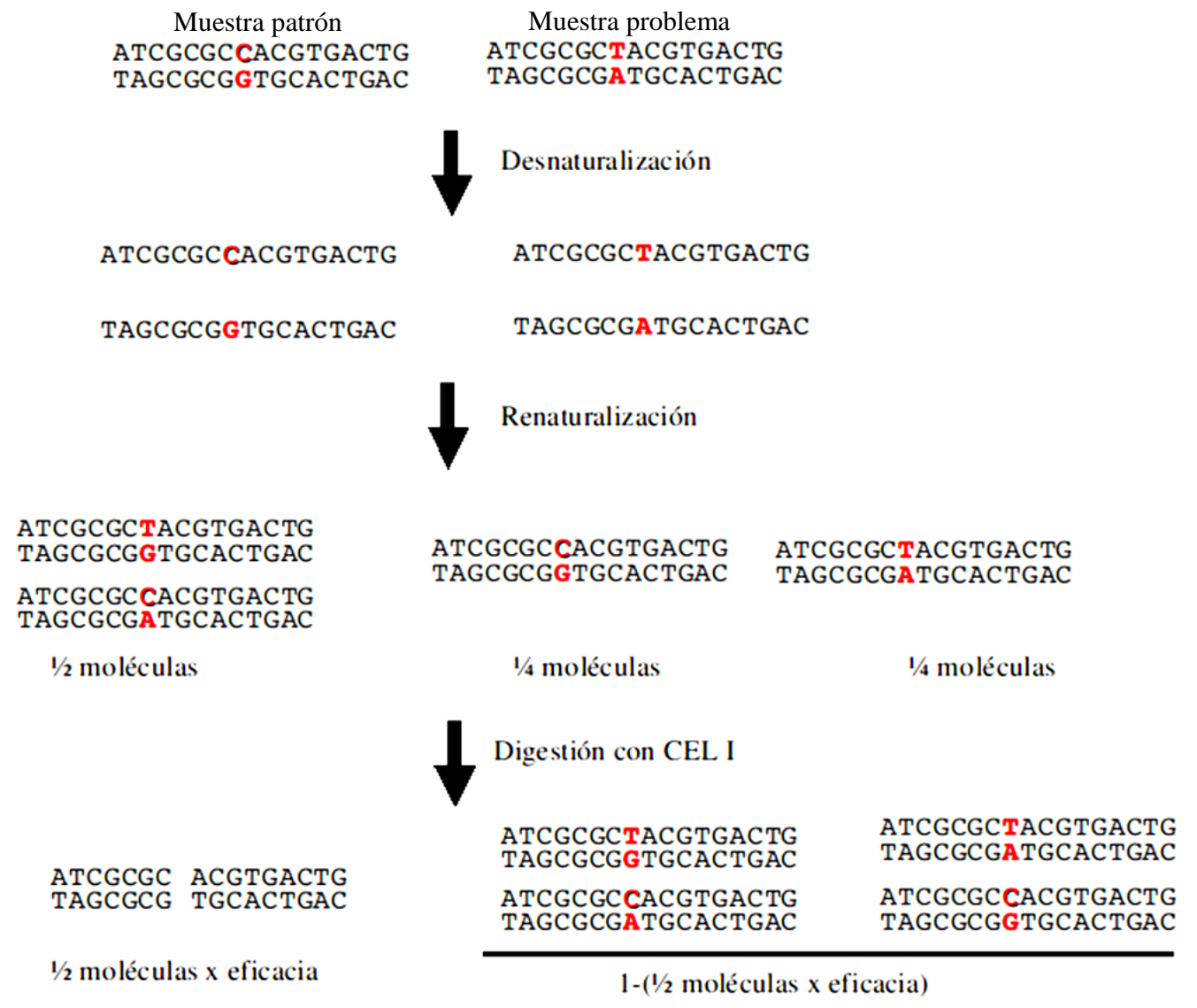

Figura 1.11: Representación de la formación de duplex entre una muestra problema y la muestra patrón seleccionada para la posterior digestión de los errores de apareamiento (Cañizares y Nuez, 2010).

Después de la identificación y verificación de las mutaciones mediante secuenciación, se formará una colección de entradas que contendrán los distintos alelos detectados en la plataforma. Así, los esfuerzos de la caracterización morfológica o fisiológica se centrarán en relacionar las distintas variantes alélicas con los fenotipos de las plantas seleccionadas. Esta es la gran ventaja de estas tecnologías, reducir el número de entradas a caracterizar al centrarse únicamente en aquellas que han mostrado variabilidad genética en el gen candidato (Cañizares y Nuez, 2010). Pero encontrar o no 
una variante alélica que produzca el fenotipo buscado depende de muchos factores. Por tanto, con este sistema de rastreo tampoco se tiene el éxito asegurado. La clave para identificar nuevos caracteres de interés utilizando EcoTILLING es la selección del gen a rastrear. Remarcamos que esta metodología está basada en la selección de un fragmento de ADN como referencia y en la detección de cualquier variante del mismo en los genomas de las entradas problema. Así, para buscar entradas que presenten variaciones en el carácter de interés hay que conocer qué genes están controlando o están implicados en ese carácter. Si la elección es incorrecta, la variación nucleotídica encontrada no estará relacionada con la variabilidad de nuestro carácter y la búsqueda habrá sido infructuosa.

El primer estudio en una especie cultivada con la técnica EcoTILLING se realizó en el arroz (Oryza sativa L.) (Kadaru et al., 2006). El EcoTILLING también se utilizó en cebada (Hordeum vulgare L.) para identificar resistencias a enfermedades fúngicas (Mejlhede et al., 2006), en una planta invasora acuática de los arrozales, Monochoria vaginalis B (Wang et al., 2007) y en el trigo (Triticum aestivum L.) para analizar alelos de los genes Pina-D1 y Pinb-D1, relacionados con la dureza del grano (Wang et al., 2008). El EcoTILLING también se ha desarrollado en el cacahuete silvestre Arachis duranensis K. \& G., para buscar nuevos alelos de un gen relacionado con reacciones alérgicas (Ramos et al., 2009). Adicionalmente, esta metodología puede utilizarse para la detección de SNPs (Single Nucleotide Polymorphisms) en poblaciones naturales (Gilchrist et al., 2006; Barkley et al., 2008; Elias et al., 2009; Galeano et al., 2009; Till et al., 2010). En melón, el EcoTILLING se ha utilizado con éxito en la detección de variantes alélicas del factor de iniciación a la traducción eIF4E, implicado en la resistencia a virus de distintas familias que ocasionan enfermedades de importancia económica en diferentes cultivos (Nieto et al., 2007). 
2. OBJETIVOS 

El principal objetivo de esta tesis se centra en el estudio y aprovechamiento de la variabilidad genética de las especies cultivadas del género Capsicum para la mejora del cultivo. Para ello, es necesario tanto conocer y describir la distribución de la variabilidad existente en las especies cultivadas, como desarrollar herramientas que permitan una exploración y utilización eficiente de la variabilidad contenida en los bancos de germoplasma. Por tanto, como objetivo concreto, se pretende desarrollar una plataforma tecnológica que permita el rastreo de la colección de Capsicum del Banco de Germoplasma del COMAV, y utilizarla para la búsqueda de variantes alélicas de los genes $e I F 4 E$ y $e I F(i s o) 4 E$, implicados en la resistencia a virosis.

En la presente tesis doctoral se pretende:

1.- Poner a punto una plataforma de EcoTILLING en el género Capsicum que permita un cribado eficiente.

2.- Explorar mediante EcoTILLING una selección de entradas de Capsicum del COMAV para la identificación de haplotipos de los genes eIF4E y eIF(iso)4E.

3.- Evaluar la funcionalidad de los nuevos alelos identificados frente a virosis causadas por potyvirus.

4.- Explorar la variabilidad genética intraespecífica e interespecífica de las especies $C$. annuum., C. frutescens, $C$. chinense, $C$. pubescens y C. baccatum. 

3. TRABAJOS PUBLICADOS 

EcoTILLING in Capsicum species: searching for new virus resistances BMC GENOMICS 



\title{
EcoTILLING in Capsicum species: searching for new virus resistances
}

\author{
Vicente P Ibiza, Joaquín Cañizares*, Fernando Nuez
}

\begin{abstract}
Background: The ECOTILLING technique allows polymorphisms in target genes of natural populations to be quickly analysed or identified and facilitates the screening of genebank collections for desired traits. We have developed an EcoTILLING platform to exploit Capsicum genetic resources. A perfect example of the utility of this EcoTILLING platform is its application in searching for new virus-resistant alleles in Capsicum genus. Mutations in translation initiation factors (elF4E, elF(iso)4E, elF4G and elF(iso)4G) break the cycle of several RNA viruses without affecting the plant life cycle, which makes these genes potential targets to screen for resistant germplasm.

Results: We developed and assayed a cDNA-based EcoTILLING platform with 233 cultivated accessions of the genus Capsicum. High variability in the coding sequences of the elF4E and elF(iso)4E genes was detected using the CDNA platform. After sequencing, 36 nucleotide changes were detected in the CDS of elF4E and 26 in elF(iso)4E. A total of 21 elF4E haplotypes and 15 elF(iso) $4 E$ haplotypes were identified. To evaluate the functional relevance of this variability, 31 possible elF4E/elF(iso)4E combinations were tested against Potato virus $Y$. The results showed that five new elF4E variants ( $p v r 2^{10}, p v r 2^{11}, p v r 2^{12}, p v r 2^{13}$ and $\left.p v r 2^{14}\right)$ were related to PVY-resistance responses.

Conclusions: EcoTILLING was optimised in different Capsicum species to detect allelic variants of target genes. This work is the first to use cDNA instead of genomic DNA in EcoTILLING. This approach avoids intronic sequence problems and reduces the number of reactions. A high level of polymorphism has been identified for initiation factors, showing the high genetic variability present in our collection and its potential use for other traits, such as genes related to biotic or abiotic stresses, quality or production. Moreover, the new elF4E and elF(iso) $4 E$ alleles are an excellent collection for searching for new resistance against other RNA viruses.
\end{abstract}

\section{Background}

The Capsicum genus consists of 27 species [1], five of which have been domesticated and are used worldwide as vegetables, spices and condiments: Capsicum annuum L., Capsicum frutescens L., Capsicum chinense J., Capsicum pubescens R. \& P. and Capsicum baccatum L. These species are cultivated around the world except for C. pubescens, which is only grown in the Andean Region. Nevertheless, non-pungent cultivars of $C$. annuum are the most-consumed, and are the main objective of most breeding programs [2]. C. pubescens, $C$. baccatum, C. chinense and C. frutescens are good sources of characters for the breeding of $C$. annuum, in addition to their economic and agronomic relevance.

\footnotetext{
* Correspondence: jcanizares@upvnet.upv.es

Instituto de Conservación y Mejora de la Agrodiversidad Valenciana

(COMAV), Universidad Politécnica de Valencia, 8E CPI, Camino de Vera s/n 46022 Valencia, Spain
}

For instance, the $L$ gene involved in resistance to Tobacco mosaic virus [3] was introgressed into modern C. annuum cultivars from $C$. frutescens, C. chinense and the wild species Capsicum chacoense H., while the Tsw gene, which determines local lesion response to Tomato spotted wilt virus [4], was introgressed from $C$. chinense. Moreover, resistance to Cucumber mosaic virus, identified in C. baccatum, has been employed to develop several tolerant cultivars in France and Hungary [5].

Genebanks maintain collections of different accessions that represent a great genetic wealth that can be explored for the breeding of traits or marker development. Nevertheless, the phenotypic characterisation of complete collections requires great effort. We need an alternative approach, one that is more efficient and less costly, in order to exploit this wealth in a practical way. EcoTILLING allows natural polymorphisms (Single Nucleotide Polymorphisms (SNPs) or small indels) to be 
identified quickly and easily in target genes [6]. The technique is based on the mutation detection approach used in TILLING (Targeting Induced Local Lesions in Genomes) $[7,8]$. The CEL I $[9,10]$ or ENDO1 [11] endonucleases are used to recognise and cut all mismatched sites present in the heteroduplex of test and standard samples. In the last few years, several studies have used this high-throughput technology in different plants. Initially, Comai et al. adapted TILLING to a natural population of Arabidopsis thaliana H. [6] and named it EcoTILLING to denote that it tests natural variability and not mutagenised populations. The first study of a cultivated species was done on rice (Oryza sativa L.) [12]. EcoTILLING has been used in barley (Hordeum vulgare L.) [13], melon (Cucumis melo L.) [14], wheat (Triticum aestivum L.) [15], wild peanut (Arachis duranensis K. \& G.) [16] and in the invasive aquatic plant Monochoria vaginalis B. [17]. EcoTILLING has also been used to detect SNPs in natural populations of several species [18-21].

As occurs with other vegetables, viral diseases are also the main limiting factor in pepper cultivation. The economic losses caused by viral diseases are quite significant, making the identification of new sources of viral resistance one of the main objectives of pepper breeders. Developing resistant cultivars provides an effective means for reducing the impact of diseases, but it requires constant effort as new virus isolates that overcome resistances are continuously produced in the host/ parasite evolution race. Screening for new resistant sources in genebanks is a laborious and expensive task, and is a perfect example of the utility of EcoTILLING, as the technique allows accessions with different alleles of candidate genes to be identified and reduces the number of samples that need to be phenotyped.

The key to identifying new traits of interest using EcoTILLING is target gene selection. The cloning of several genes that confer recessive resistance to viruses has shown that they code for eukaryotic translation initiation factors of the $4 \mathrm{~F}$ family. The factor $4 \mathrm{~F}$ is made up of two subunits: eIF4E and eIF4G. An isoform of eIF4F, eIF(iso)4F, which is formed by the eIF(iso) $4 \mathrm{E}$ and eIF (iso)4G subunits, has been identified in plants [22]. Alleles of C. annuum (pvr2), C. chinense (pvr1) and Solanum habrochaites S. \& D. (pot-1) that confer resistance to Potato virus $Y$ (PVY) and Tobacco etch virus (TEV) code for the translation initiation factor $4 \mathrm{E}$, eIF4E [23-28]. Mutant alleles of the eIF4E gene block the multiplication of other members of the Potyviridae family in different crops: lettuce [29], pea [30,31], watermelon [32], barley [33] and common bean [34]. Another example of resistance to potyviruses are the EMS-induced mutant alleles at the $l s p 1$ locus of $A$. thaliana that code for the $\operatorname{eIF}$ (iso)4E factor [35]. The combination of eIF4E and $\mathrm{eIF}$ (iso)4E mutations in pepper confers resistance to Pepper veinal mottle virus [36,37] and Chilli veinal mottle virus [38]. There are also examples of mutations in the eIF4E, eIF4G and eIF(iso) $4 \mathrm{G}$ initiation factors that confer resistance to other viral families in different species: in melon (Melon necrotic spot virus, family Tombusviridae) [14], A. thaliana (Cucumber mosaic virus, family Bromoviridae and Turnip crinkle virus, family Tombusviridae) [39] and in rice (Rice yellow mottle virus, Sobemovirus Genus, family unassigned) [40]. All these data show that the interaction between plant translation initiation factors and viral RNA is necessary for viral replication and complete infection $[41,42]$. Studies have demonstrated that the interaction between eIF4E and VPg is necessary for potyviruses to complete their infectious cycle, and that eIF4E resistance-related factors alter the VPg binding function [24,25]. It is therefore apparent that certain mutations in translation initiation factors (eIF4E, eIF(iso)4E, eIF4G and eIF(iso) $4 \mathrm{G}$ ) break the virus cycle without affecting the plant life cycle. It is also clear that an interruption of viral infection can occur when a host factor is modified. For instance, mutations in the eIF4E factor inhibit the multiplication of Potato virus $Y[23,25]$, one of the most aggressive pathogens of pepper worldwide. This virus causes distortion and mosaic on leaves and plant stunting, as well as deformation of fruits, producing severe yield reductions. Thus, these genes are potential targets in the search for new resistant sources to this and other viruses, and in identifying resistance alleles to effectively combat the appearance of new isolates that break resistance, as viral pathogens must generate a new function to overcome new resistance.

In this paper, we have developed a cDNA-based EcoTILLING platform in pepper. We have used cDNA to detect haplotype variants of the eIF $4 E$ and $\operatorname{eIF}$ (iso) $4 E$ genes inside CDS (coding sequence). This approach avoids intron sequences and reduces the difficulty of amplifying target genes from different species [14]. 36 and 26 nucleotide changes have been identified in $e I F 4 E$ and $\operatorname{IIF}$ (iso) $4 E$, respectively. Our results demonstrate that this platform contains enough variability to detect new mutations in the eIF4E and eIF(iso) $4 E$ genes in pepper. Moreover, to demonstrate the utility of these new allelic variants, we have tested them for PVY resistance. Five new resistance alleles of the $I F 4 E$ gene were detected. These results show the utility of this platform in searching for new alleles of other candidate genes, which will be very useful in pepper breeding.

\section{Results}

\section{cDNA-based EcoTILLING platform}

We analysed 229 cultivated accessions of the Capsicum genus (C. annuum, C. pubescens, C. chinense, C. frutescens 
and $C$. baccatum) and 4 accessions of two wild species ( $C$. chacoense and Capsicum eximium $\mathrm{H}$.) (see Additional file 1). These accessions were selected from the COMAV genebank according to their geographical origin and morphological variability. The accessions were collected from South America (Peru, Ecuador, Bolivia and Chile), where cultivated peppers show high morphological and genetic variability [43], and from the Canary Islands. We built up a cDNA platform in 96-well format.

\section{Screening of the elF4E gene by EcoTILLING}

The $e I F 4 E$ gene in pepper is organised into five exons and shows a conserved exon/intron structure when compared to A. thaliana and rice [44]. We used the cDNA platform for the screening to detect $e I F 4 E$ allelic variants. This strategy avoids the problem of intron localisation and variability and reduces the number of PCR and CEL I reactions. The completed ORF (open reading frame) was amplified by nested PCR, using two specific 3' UTR primers and a forward primer from the beginning of the CDS. A unique band was obtained in most of the accessions, but no amplification bands were obtained in 17 accessions of C. pubescens, 5 of C. baccatum, 4 of $C$. frutescens, 1 of $C$. chinense nor in any accessions of $C$. eximium, even though different amplification conditions were assayed. The amplified cDNA was quantified and used in the EcoTILLING reaction. In a first round of classification, all accessions were compared against the cDNA of the CDP04928 accession, and 36 different bands were detected. Samples were classified according to the presence or absence of these bands, including weak bands, in order to maximise the identification of very similar haplotypes. Finally, 55 different patterns were obtained and used to group the accessions. Sixteen samples showed no band and were classified with the CDP04928 group. The majority of groups were species-specific, and 34 groups contained only one accession. To confirm this initial classification, an internal standard sample was selected in the more numerous groups and common standards for the smaller groups with a similar band pattern. After doing the enzyme reactions with the new standards, a more detailed classification was done and the groups were reduced to 46 .

To determine the allelic variants of the $I F 4 E$ gene, an accession from each group was selected and sequenced. After cDNA sequencing, the 46 groups were reduced to 29, as several EcoTILLING groups with similar band patterns and few samples were shown to have the same sequence. This discrepancy between EcoTILLING and sequencing groups could be explained by the presence of mutations in nearby sites, partial digestions, experimental errors and the inclusion of weak bands to maximise haplotype identification. In the end, 20 groups corresponded to homozygous samples and 9 to heterozygous samples. Most of the haplotypes were species-specific (see Table 1 and Additional file 1), but $e I F 4 E_{-} B 1$ was detected in $C$. annuum and $C$. chinense, eIF4E_G1 in C. chinense and $C$. frutescens and eIF4E_F3 was present in all three. The most variable species was $C$. baccatum, with eight alleles in both homozygous and heterozygous plants. In contrast, C. pubescens showed only one haplotype, eIF4EJ1. Seven heterozygous plants of $C$. baccatum were inferred from the haplotypes found in other accessions. In one instance of $e I F 4 E_{-} Q 1 S h 1$, the $e I F 4 E_{-} S h 1$ haplotype had not been detected in homozygosis. The other heterozygous plants were detected in C. chinense (eIF4E_F3H1) and $C$. frutescens (eIF4E_F2G1).

After the sequencing analysis, 34 polymorphic sites were detected in all exons except in exon 4 . The number of changes per exon was 14 in exon 1, 5 in exon 2, 5 in exon 3 and 10 in exon 5 . A total of 36 changes were identified, as two sites showed three different nucleotides. Nucleic acid sequences for each haplotype were translated, and 12 nucleotidic changes of the 36 were synonymous.

The sequences were aligned with the published alleles (data not shown). The sequenced ORFs from two haplotypes were identical to others previously found in different studies: the $I F 4 E[E 1$ nucleotide sequence was identical to the $p v r 2^{1}$ allele of cultivar Yolo Y [Genbank: AF521964] [23], as was the $e I F 4 E_{-} B 1$ sequence to allele $p v r 2^{+}$carried by Yolo Wonder [Genbank: AY122052] [23] and Doux Long des Landes [Genbank: AF521963] [23].

\section{Analysis of the elF4E amino acid sequence}

The translation of nucleotide sequences resulted in 24 non-silent changes. However, these mutations resulted in 23 amino acid changes, as two mutations of $C$. pubescens affected the same codon (see Additional file 2). The 21 nucleotidic sequences from haplotypes were translated and 19 different predicted proteins were identified (Table 2). Most of the mutations were located in exon 1 , where 12 amino acid substitutions were identified, five of which generated a change of charge in the amino acid. The majority of the changes were species-specific, but four mutations (N65 D, A73 D, L79R and T131I) were shared by different species (Table 1 and Table 2). C. chinense had the largest number of specific non-silent changes with six mutations (T51A, P66T, G107R, D213 H, L218R and L218F), whereas only one change was detected in $C$. frutescens (A15V) and C. chacoense (A15T).

The eIF4E proteins identified in our EcoTILLING platform as well as the proteins already published in the databases and articles were aligned with Clustal X (data not shown). Apart from the published haplotypes, eIF4E_E1 and $e I F 4 E_{-} B 1$, several partial proteins of the eIF4E factor were identical to already known proteins. 


\begin{tabular}{|c|c|c|c|c|c|c|}
\hline Haplotype $^{\mathrm{a}}$ & C. annuum & C. chinense & C. frutescens & C. baccatum & C. pubescens & C. chacoense \\
\hline elF4E_Al & 13.3 & & & & & \\
\hline$e\left|F 4 E_{-} B\right|$ & 46.7 & 2.5 & & & & \\
\hline elF $4 E_{-} C l$ & & & & & & 100 \\
\hline elF $4 E_{-} D 1$ & & 10 & & & & \\
\hline$\left.e l F 4 E_{-} E\right\}$ & 36.7 & & & & & \\
\hline elF4E_F1 & & & & 37.1 & & \\
\hline elF $4 E_{-} F 2$ & & & 15.9 & & & \\
\hline elF4E_F2G1 & & & 4.5 & & & \\
\hline elF $4 E_{-} F 3$ & 3.3 & 50 & 56.8 & & & \\
\hline elf $4 E_{-} F 3 H 1$ & & 2.5 & & & & \\
\hline elf $4 E_{-} G \mid$ & & 2.5 & 20.5 & & & \\
\hline elf $4 E_{-} H I$ & & 2.5 & & & & \\
\hline elf4E_/I & & 20 & & & & \\
\hline elF4E_Jl & & & & & 100 & \\
\hline elF $4 E_{-} K l$ & & & & 7.1 & & \\
\hline elF $\left.4 E_{-} L\right\}$ & & & & 2.9 & & \\
\hline elF $\left.4 E_{-} L I F\right\}$ & & & & 1.4 & & \\
\hline elF4E_LINT & & & & 1.4 & & \\
\hline elF $4 E_{-} M 1$ & & & & 4.3 & & \\
\hline elF $4 E_{-} M 1 N 1$ & & & & 1.4 & & \\
\hline elF $4 E_{-} N 1$ & & & & 17.2 & & \\
\hline elF4E_NIQ1 & & & & 1.4 & & \\
\hline elFAE_Ol & & & & 8.6 & & \\
\hline elF4E_OIFI & & & & 5.8 & & \\
\hline elf $4 E_{-} P 1$ & & 10 & & & & \\
\hline elF $4 E_{-} Q 1$ & & & & 8.6 & & \\
\hline elF4E_Q1FI & & & & 1.4 & & \\
\hline elF $4 E_{-} R 1$ & & & 2.3 & & & \\
\hline elf $4 E_{-} Q 1 S h 1^{\mathrm{b}}$ & & & & 1.4 & & \\
\hline
\end{tabular}

a, Haplotypes were named with a letter (coded protein) and a number (nucleotide variant). The heterozygous plants were named according to the two known haplotypes when identified in homozygosis. b, Heterozygote with one allele detected in homozygosis (elF4E_Q1) and the other undetected (elF4E_Sh1).

Thus, the eIF4E_F1, eIF4E_F2 and eIF4E_F3 haplotypes with synonymous changes code for the same protein, eIF4E_F. This protein was the same as the eIF4E protein of cultivars that carry the pvr1 ${ }^{+}$allele, Habanero [Genbank: AAR23917] [24] and Diego [Genbank: AAV88619]. The accessions with the eIF4E_A protein had the same amino acids as the pvr2 ${ }^{2}$ allele of $\mathrm{cv}$. Dempsey [Genbank: AAR23920] [24], and the eIF4E_I protein was identical to the eIF4E protein of the pvr1 alleles identified in USDA accessions, PI159234 [Genbank: AAR23918] [24] and PI152225 [Genbank: AAV88618]. Finally, we detected 14 amino acid changes and 14 protein variants (including eIF4E_Sh) that had not been previously published (Table 2 ).

\section{Screening of the elF(iso) $4 E$ gene by EcoTILLING}

Amplification and analysis of the $\operatorname{IF}$ (iso) $4 E$ coding sequence was carried out as with the eIF4E gene. The exon/intron structure of the $\operatorname{eIF}$ (iso) $4 E$ gene is unknown in pepper but has been described in tomato [Genbank:
GQ451832, Genbank: GQ451833] and A. thaliana [Genbank: AF538308]. This initiation factor is organised into 5 exonic regions. The exon/intron structure will most likely be conserved in pepper, but the intron sequence most likely will not. As a result, to amplify the exons it will be necessary to sequence the intron boundaries in order to develop the eIF(iso)4E primers. The cDNA platform was therefore used to detect eIF(iso) $4 E$ allelic variants.

All samples were amplified and quantified by agarose gel. For this gene, the cDNA of the CDP06433 accession was chosen as reference and mixed with the other samples in the first grouping. After enzymatic digestion, a total of 21 bands were selected between $140 \mathrm{bp}$ and 600 bp. All of these bands were used to classify the samples into 27 groups. To confirm the initial classification, new reactions were carried out using an internal standard for each large group and a common standard for related smaller ones. Finally, the samples were classified into 31 groups; of these, two groups contained $47 \%$ of the 
Table 2 Differences in amino acid substitutions of detected haplotypes in the elF4E gene

\begin{tabular}{|c|c|c|c|c|c|c|c|c|c|c|c|c|c|c|c|c|c|c|c|c|c|c|c|}
\hline \multirow{3}{*}{$\begin{array}{l}\text { elF4E } \\
\text { protein }\end{array}$} & \multirow{3}{*}{$\begin{array}{c}\text { New } \\
\text { allele } \\
\text { names }\end{array}$} & \multicolumn{9}{|c|}{ Published proteins } & \multicolumn{12}{|c|}{ Exon and amino acid position ${ }^{a}$} & \multirow[b]{2}{*}{5} \\
\hline & & $\begin{array}{l}\text { Allele } \\
\text { name }\end{array}$ & $\begin{array}{l}\text { Cultivar or } \\
\text { accession }\end{array}$ & 1 & 1 & 1 & 1 & 1 & 1 & 1 & 1 & 1 & 1 & 2 & 2 & 2 & 3 & 5 & 5 & 5 & 5 & 5 & \\
\hline & & & & 15 & 51 & 65 & 66 & 67 & 71 & 73 & 74 & 77 & 79 & 107 & 109 & 131 & 160 & 213 & 214 & 216 & 218 & 219 & 22 \\
\hline elF4E_B & & $p_{v r 2^{+}}$ & Yolo Wonder & A & T & $\mathrm{N}$ & P & V & K & A & A & s & L & G & D & T & $\mathrm{E}$ & D & D & K & L & D & $\mathrm{N}$ \\
\hline elF4E_A & & $p v r 2^{2}$ & Dempsey & - & - & - & - & $E$ & - & - & - & - & $R$ & - & N & - & - & - & - & - & - & - & - \\
\hline elF4E_E & & $p v r 2^{l}$ & Yolo Y & - & - & - & - & $E$ & - & - & - & - & $R$ & - & - & - & - & - & - & - & - & - & - \\
\hline elF4E_R & $p \vee r 2^{17}$ & & & v & - & - & - & - & $R$ & - & - & - & - & - & - & - & - & - & - & - & - & - & - \\
\hline elF4E_C & pvr2 $2^{15}$ & & & $T$ & - & - & - & - & $R$ & - & - & - & - & - & - & - & - & - & - & - & - & - & - \\
\hline elF4E_Q & $p v r 2^{22}$ & & & - & - & - & - & - & $R$ & - & - & 1 & - & - & - & - & - & - & - & - & - & - & - \\
\hline elF4E_F & & $p v r 1^{+}$ & Habanero & - & - & - & - & - & $R$ & - & - & - & - & - & - & - & - & - & - & - & - & - & - \\
\hline elF4E_G & $p v r 2^{16}$ & & & - & - & - & - & - & $R$ & - & - & - & - & - & - & 1 & - & - & - & - & - & - & - \\
\hline elF4E_L & $p v r 2^{19}$ & & & - & - & - & - & - & $R$ & - & - & - & $R$ & - & - & - & - & - & - & - & - & - & - \\
\hline elF4E_J & $p v r 2^{18}$ & & & - & - & - & - & - & $R$ & - & - & - & - & - & - & - & G & - & $E$ & A & - & $E$ & - \\
\hline elF4E_N & $p v r 2^{13}$ & & & - & - & D & - & - & $R$ & - & D & - & - & - & - & - & - & - & - & - & - & - & - \\
\hline elF4E_O & $p v r 2^{14}$ & & & - & - & D & - & - & $R$ & - & - & - & - & - & - & - & - & - & - & - & - & - & - \\
\hline elF4E_H & $p v r 2^{11}$ & & & - & - & D & - & - & $R$ & - & - & - & - & - & - & - & - & $\mathrm{H}$ & - & - & $R$ & - & - \\
\hline elF4E_K & $p v r 2^{12}$ & & & - & - & D & - & - & $R$ & D & - & - & - & - & - & - & - & - & - & - & - & - & $\begin{array}{ll}- \\
-\end{array}$ \\
\hline elf4E_Sh ${ }^{b}$ & - & & & - & - & D & - & - & $R$ & - & D & - & - & - & - & 1 & - & - & - & - & - & - & $\mathrm{s}$ \\
\hline elF4E_M & $p v r 2^{20}$ & & & - & - & - & - & - & $R$ & T & - & - & - & - & - & - & - & - & - & - & - & - & - \\
\hline elF4E_I & & pvrl & PI152225 & - & A & - & $\mathrm{T}$ & - & $R$ & - & - & - & - & $R$ & - & - & - & - & - & - & - & - & - \\
\hline elF4E_D & $p v r 2^{10}$ & & & - & - & - & T & - & $R$ & D & - & - & - & $R$ & - & - & - & - & - & - & $\mathrm{F}$ & - & - \\
\hline elF4E_P & pur2 $2^{21}$ & & & - & A & - & - & - & $R$ & & & - & - & - & - & - & - & - & - & - & - & - & - \\
\hline
\end{tabular}

$a$, The alignment and amino acid positions are numbered according to the published elF4E protein of pvr $2^{+}$allele. $b$, Protein from elF4E_Sh1-inferred haplotype was not named but had been used to analyse the variable positions.

samples: one with $58 \%$ of the C. baccatum plants and another with $75 \%$ of the accessions of $C$. chinense and C. frutescens.

A sample from each group was selected and sequenced. After cDNA sequencing, the 31 groups were reduced to 17 because some EcoTILLING groups had the same sequence, as was previously detected for the eIF $4 E$ gen. These false positive rates were due to weak bands that were taken into account to minimise the haplotype loss. The eIF(iso) $4 E$ sequences of Capsicum showed a high level of polymorphism. Thus, 25 polymorphic nucleotide positions over the CDS were detected and 26 nucleotide changes were identified. One position had three different nucleotides.

A total of 15 haplotypes of the $\operatorname{eIF}$ (iso) $4 E$ gene were detected (see Table 3 and Additional file 1). All haplotypes were species-specific except eIF(iso) $4 E_{-} B 1$, which was present in all accessions of $C$. chinense and was also the most common in $C$. frutescens. Only three heterozygous samples were detected, one in C. annuum, eIF(iso) $4 E_{-} D 1 C 1$, and two in C. pubescens, eIF(iso) $4 E_{-} H 1 I h 1$, with inferred haplotype $e I F(i s o) 4 E_{-} I h 1$ not detected in homozygosis, and eIF(iso) 4 E_het, with unknown phase. C. pubescens and C. baccatum were the most variable for the eIF(iso)4E initiation factor, as each showed between four and five different haplotypes. Only the $\operatorname{eIF}$ (iso) $4 E_{-} C 1$ nucleotide sequence was identical to a previously published allele, $p v r 6^{+}$carried by FloridaVR2 [Genbank: DQ022082] [36], Yolo Y [Genbank: DQ022081] [36] and Yolo Wonder [Genbank: DQ022080] [36] cultivars. All the partial sequences of $e I F$ (iso) $4 E$ ORFs (including $e I F$ (iso) $4 E$ Jhet) were translated, and 12 changes out of 26 were synonymous.

\section{Analysis of the elF(iso)4E amino acid sequence}

Fourteen non-synonymous changes were identified in homozygous and heterozygous individuals (Table 4). These mutations were located between the N-term of the protein and the middle region, up to the $119^{\text {th }}$ amino acid (see Additional file 3). Only three changes were shared by the different species: A20E (C. pubescens and $C$. chacoense), P27 S (C. chinense and C. frutescens) and A90T (C. annuum, C. chinense and C. frutescens); the other 11 mutations were specific to different species. Although only two accessions of $C$. eximium were sequenced, it was, along with $C$. pubescens, the species with the most specific mutations, as each had four changes. One non-synonymous change was detected in C. chacoense (T119I) as were two others in C. baccatum (P16T and A20T). 
Table 3 Frequency of elF(iso)4E haplotypes detected in Capsicum spp. by EcoTILLING

\begin{tabular}{|c|c|c|c|c|c|c|c|}
\hline Haplotype $^{a}$ & C. annuum & C. chinense & C. frutescens & C. baccatum & C. pubescens & C. chacoense & C. eximium \\
\hline elF(iso)4E_Al & & & & 25.3 & & & \\
\hline elF(iso) $4 E_{-} B 1$ & & 100 & 79.2 & & & & 50 \\
\hline elF(iso)4E_Cl & 66.7 & & & & & & \\
\hline elF(iso) $4 E_{-} C 2$ & & & 20.8 & & & & \\
\hline elf(iso) $4 E_{-} C 3$ & & & & 4 & & & \\
\hline elF(iso) $4 E_{-} C 4$ & & & & 64 & & & \\
\hline elf(iso) $4 E_{-} C 5$ & & & & 2.7 & & & \\
\hline elF(iso)4E_D1 & 26.7 & & & & & & \\
\hline elF(iso) $4 E_{-} D 1 C 1$ & 6.6 & & & & & & \\
\hline elF(iso)4E_El & & & & & & 100 & \\
\hline elF(iso) $4 E_{-} F$ I & & & & 4 & & & \\
\hline elF(iso)4E_Gl & & & & & 34.3 & & \\
\hline elF(iso)4E_G2 & & & & & 25.6 & & \\
\hline elF(iso) $4 E_{-} H T$ & & & & & 34.3 & & \\
\hline elF(iso) $\left.4 E_{-} H I h\right]^{\mathrm{b}}$ & & & & & 2.9 & & \\
\hline elF(iso) $4 E_{-}$Jhet $^{c}$ & & & & & 2.9 & & \\
\hline elf(iso)4E_KI & & & & & & & 50 \\
\hline
\end{tabular}

a, Haplotypes were named with a letter (coded protein) and a number (nucleotide variant). The heterozygous plants were named according to the two known haplotypes when identified in homozygosis. b, Heterozygote with one allele detected in homozygosis (elF(iso) $4 E_{-} H 1$ ) and the other undetected (elF(iso) $4 E_{-} / \mathrm{h} 1$ ). c, Heterozygote with unknown phase.

An alignment with the Clustal X program was carried out which included the partial eIF(iso)4E proteins detected and those already published. Besides the $e I F$ (iso) $4 E_{-} C 1$ sequence ( $p v r 6^{+}$allele), the haplotypes eIF (iso) $4 E_{-} C 2$, eIF(iso) $4 E_{-} C 3$, eIF(iso) $4 E_{-} C 4$ and eIF(iso) $4 E_{-} C 5$ coded for the same protein, eIF(iso)4E_C, which was detected in $36 \%$ of the accessions. The other nine detected haplotypes did not correspond to any known protein variant.

Response of selected accessions by EcoTILLING to mechanical inoculation with the F14K isolate of PVY A screening with Potato virus $Y$ was done to discover if the new eIF4E and $\operatorname{IIF}($ iso $) 4 E$ alleles detected in homozygosis confer resistance to this virus. In our EcoTILLING collection, we identified 18 eIF4E and 9 eIF(iso) $4 \mathrm{E}$ proteins in homozygosis. We tested 33 accessions which represent 31 of the $32 \mathrm{eIF} 4 \mathrm{E} / \mathrm{eIF}$ (iso) $4 \mathrm{E}$ combinations (Table 5). These plants were inoculated mechanically with PVY-F14K isolate. The susceptible controls, Negral (CDP02198) and Agridulce (CDP05523), were infected and were DAS-ELISA positive, showing symptoms as of the beginning of the survey (15 days post inoculation (DPI)) (Table 5). These susceptible accessions showed leaf deformation, venal chlorosis and mosaic. Dark green veinbanding and stunted growth were detected later in these plants (Figure 1). These lesions were used to score the PVY symptoms from 0 for symptomless plants to 4 for

Table 4 Differences in amino acid substitutions of detected haplotypes in the eIF(iso)4E gene

\begin{tabular}{|c|c|c|c|c|c|c|c|c|c|c|c|c|c|c|}
\hline \multirow[t]{2}{*}{ elF(iso)4E protein } & \multirow[t]{2}{*}{ New allele Names } & \multicolumn{2}{|c|}{ Published proteins } & \multicolumn{11}{|c|}{ Position of amino acid change ${ }^{a}$} \\
\hline & & Allele name & Cultivar & 15 & 16 & 20 & 24 & 27 & 56 & 63 & 90 & 109 & 115 & 119 \\
\hline elF(iso)4E_C & & $p_{v r \sigma^{+}}$ & F/YYMW & $\mathrm{P}$ & $P$ & A & V & $P$ & K & V & A & V & A & $\mathrm{T}$ \\
\hline elF(iso)4E_A & $p v r 6^{2}$ & & & - & - & $\mathrm{T}$ & - & - & - & - & - & - & - & - \\
\hline elF(iso)4E_F & pvr6 ${ }^{6}$ & & & - & $\mathrm{T}$ & - & - & - & - & - & - & - & - & - \\
\hline elF(iso)4E_D & $p v r 6^{4}$ & & & - & - & - & - & - & - & - & T & - & - & - \\
\hline elF(iso)4E_B & pvr6 ${ }^{3}$ & & & - & - & - & - & S & - & - & $T$ & - & - & - \\
\hline elF(iso)4E_K & pvro ${ }^{8}$ & & & $\mathrm{~T}$ & - & - & $E$ & - & $\mathrm{N}$ & - & - & - & $P$ & - \\
\hline elF(iso)4E_H & pvr $6^{7}$ & & & - & - & E & A & - & - & । & - & - & - & - \\
\hline elF(iso)4E_Ih ${ }^{c}$ & - & & & - & - & $E$ & $S$ & - & - & 1 & - & - & - & - \\
\hline elF(iso)4E_G & $p v r 6^{9}$ & & & - & - & $E$ & A & - & - & - & - & - & - & - \\
\hline elF(iso)4E_E & pvr $6^{5}$ & & & - & - & $E$ & - & - & - & - & - & - & - & I \\
\hline elF(iso) $4 \mathrm{E} \_J \mathrm{~h}^{\mathrm{c}}$ & - & & & - & - & $-/ E$ & $-/ A$ & - & - & $-/ 1$ & - & $-/ A$ & - & - \\
\hline
\end{tabular}

a, The alignment and amino acid positions are numbered according to the published elF(iso)4E protein of pvr6 ${ }^{+}$allele. b, F: Florida VR2.YY: Yolo Y. YW: Yolo Wonder. c. Proteins from inferred or unknown haplotypes were not named but were used to analyse the variable positions. 
Table 5 Development of PVY-F14K infection during screening and response in selected accessions

\begin{tabular}{|c|c|c|c|c|c|c|c|c|c|c|c|c|}
\hline \multirow[t]{2}{*}{ Accession } & \multirow[t]{2}{*}{ Species } & \multirow[t]{2}{*}{ elF4E/elF(iso)4E proteins } & \multicolumn{4}{|c|}{ Mean symptom index ${ }^{a}$} & \multicolumn{4}{|c|}{ Mean absorbance $\left(\mathrm{A}_{405}\right)^{\mathrm{a}}$} & \multirow{2}{*}{$\%$ positive plants ${ }^{c}$} & \multirow[t]{2}{*}{ Response $^{d}$} \\
\hline & & & $15 D^{b}$ & $30 \mathrm{D}$ & $45 \mathrm{D}$ & $60 \mathrm{D}$ & $15 \mathrm{D}$ & $30 \mathrm{D}$ & $45 \mathrm{D}$ & $60 \mathrm{D}$ & & \\
\hline CDP06188 & C. annuum & $A C$ & 0 & 0 & 0 & 0 & 0.05 & 0.03 & 0.03 & 0.02 & 0 & $\mathrm{R}$ \\
\hline CDP09688 & C. annuum & B_CD & 0 & 0 & 0 & 0 & 0.02 & 0.02 & 0.02 & 0.02 & 0 & $\mathrm{R}$ \\
\hline CDP01263 & C. chinense & $\mathrm{BB}$ & 3.5 & 2.5 & 1.5 & 1 & 1.24 & 0.89 & 0.65 & 0.29 & 100 & S \\
\hline CDP04928 & C. annuum & $B C$ & 0 & 0 & 0.5 & 1 & 0.07 & 0.46 & 0.72 & 0.37 & 100 & $s$ \\
\hline CDP01246 & C. annuum & BD & 0.5 & 0.9 & 1.1 & 1.5 & 0.27 & 0.51 & 0.61 & 0.57 & 100 & $S$ \\
\hline CDP08791 & C. chacoense & CE & 2 & 2.5 & 3.5 & 3.5 & 0.85 & 1.81 & 1.73 & 1.79 & 100 & S \\
\hline CDP02521 & C. chinense & DB & 0 & 0 & 0 & 0 & 0.04 & 0.03 & 0.02 & 0.02 & 0 & $\mathrm{R}$ \\
\hline CDP06433 & C. annuum & EC & 0 & 0 & 0 & 0 & 0.03 & 0.02 & 0.02 & 0.05 & 0 & R \\
\hline CDP01135 & C. annuum & ED & 0 & 0 & 0 & 0 & 0.03 & 0.02 & 0.01 & 0.01 & 0 & R \\
\hline CDP00614 & C. baccatum & FA & 0 & 0 & 0 & 0 & 0.54 & 0.25 & 0.17 & 0.26 & 100 & T \\
\hline CDP05838 & C. frutescens & $F B$ & 0 & 1.6 & 1 & 0.5 & 0.76 & 0.67 & 0.52 & 0.97 & 100 & s \\
\hline CDP00624 & C. baccatum & FC & 0 & 0.5 & 0.5 & 0 & 0.87 & 0.35 & 0.14 & 0.35 & 100 & $S$ \\
\hline CDP06234 & C. baccatum & FC & 0 & 0 & 0 & 0 & 0.04 & 0.03 & 0.02 & 0.03 & 0 & R \\
\hline CDP00620 & C. annuum & FD & 0.9 & 1.9 & 2.3 & 1.9 & 0.64 & 1.01 & 1.37 & 1.12 & 100 & s \\
\hline CDP05436 & C. frutescens & GB & 0 & 0.9 & 1.3 & 1 & 1.36 & 0.88 & 0.98 & 1.33 & 100 & s \\
\hline CDP00973 & C. frutescens & GC & 0 & 0.8 & 1 & 0.8 & 1.21 & 0.66 & 1.39 & 1.09 & 100 & s \\
\hline CDP08407 & C. chinense & $\mathrm{HB}$ & 0 & 0 & 0 & 0 & 0.01 & 0.01 & 0.01 & 0.03 & 0 & R \\
\hline CDP07700 & C. chinense & $\mathrm{IB}$ & 0 & 0 & 0 & 0 & 0.26 & 0.22 & 0.03 & 0.03 & 60 & T \\
\hline CDP00590 & C. pubescens & $J G$ & 2 & 2.4 & 1 & 0.2 & 1.81 & 1.6 & 0.68 & 1.55 & 100 & s \\
\hline CDP04291 & C. baccatum & KA & 0 & 0 & 0 & 0 & 0.03 & 0.04 & 0.03 & 0.02 & 0 & R \\
\hline CDP02320 & C. baccatum & KC & 0 & 0 & 0 & 0 & 0.03 & 0.03 & 0.02 & 0.04 & 0 & R \\
\hline CDP05581 & C. baccatum & LC & 0 & 0 & 0 & 0 & 1.64 & 1.13 & 0.76 & 0.32 & 100 & $\mathrm{~T}$ \\
\hline CDP06360 & C. baccatum & $M C$ & 0 & 0 & 0 & 0 & 0.07 & 0.08 & 0.09 & 0.09 & 60 & $\mathrm{~T}$ \\
\hline CDP07825 & C. baccatum & MF & 0 & 0 & 0 & 0 & 0.43 & 0.41 & 1.61 & 1.32 & 100 & $\mathrm{~T}$ \\
\hline CDP04865 & C. baccatum & NA & 0 & 0 & 0 & 0 & 0.03 & 0.04 & 0.04 & 0.06 & 0 & $\mathrm{R}$ \\
\hline CDP07490 & C. baccatum & NC & 0 & 0 & 0 & 0 & 0.05 & 0.02 & 0.02 & 0.03 & 0 & $\mathrm{R}$ \\
\hline CDP04131 & C. baccatum & NF & 0 & 0 & 0 & 0 & 0.05 & 0.05 & 0.04 & 0.06 & 0 & $\mathrm{R}$ \\
\hline CDP09967 & C. baccatum & $O A$ & 0 & 0 & 0 & 0 & 0.04 & 0.04 & 0.02 & 0.02 & 0 & $\mathrm{R}$ \\
\hline CDP09334 & C. baccatum & $O C$ & 0 & 0 & 0 & 0 & 0.03 & 0.04 & 0.03 & 0.04 & 0 & $\mathrm{R}$ \\
\hline CDP01186 & C. chinense & PB & 2.5 & 3 & 3 & 3.5 & 0.88 & 0.19 & 0.23 & 0.25 & 100 & s \\
\hline CDP05929 & C. baccatum & $\mathrm{QA}$ & 0 & 0 & 0 & 0 & 0.03 & 0.02 & 0.02 & 0.01 & 0 & $R$ \\
\hline CDP04710 & C. baccatum & $Q C$ & 0 & 0 & 0 & 0 & 0.33 & 0.18 & 0.13 & 0.16 & 100 & T \\
\hline CDP06951 & C. frutescens & $\mathrm{RB}$ & 0 & 0 & 0 & 0 & 1.44 & 0.77 & 1.21 & 1.34 & 100 & $T$ \\
\hline CDP02198 & C. annuum & Control & 0.7 & 1.7 & 1.5 & 1.9 & 0.41 & 0.34 & 0.33 & 0.32 & 100 & $S$ \\
\hline CDP05523 & C. annuum & Control & 2.1 & 2.8 & 3.2 & 3.5 & 0.88 & 0.6 & 0.7 & 1.27 & 100 & $S$ \\
\hline
\end{tabular}

a, Arithmetic mean calculated from all plants of the accession at each time sampling. The symptom index ranged from 0 (symptomless plant) to 4 (dead plant). b, D: Days post inoculation. c, Percentage of DAS-ELISA positive plants. Plants were considered to be DAS-ELISA positive when absorbance (405 nm) of sample from the youngest leaf was higher than three times the negative control mean, and classified as non-infected (DAS-ELISA negative) when the value of absorbance was below this threshold. The negative control mean was calculated for each accession with different time samplings (15, 30, 45 and 60 days post inoculation). d, R: Resistant. No plants were infected systemically and no symptoms were identified. S: Susceptible. Showed DAS-ELISA positive and systemic symptoms. T: Tolerant. Showed DAS-ELISA positive in all or some plants but without symptoms.

dead plants. In Agridulce, the cultivar symptoms score and DAS-ELISA absorbance mean were higher than in Negral. Absorbance was higher than 0.60 in Agridulce plants and 0.32 in Negral. The F14K isolate of PVY completed the viral cycle in all analysed species and no plant died during the experiment (data not shown). The CDP01246, CDP04928 and CDP00620 accessions of C. annuum, CDP01263 and CDP01186 of C. chinense, CDP05838, CDP05436, CDP00973 of C. frutescens and the single accessions of $C$. chacoense (CDP08791) and C. pubescens (CDP00590) showed a similar response to that of the susceptible controls. The CDP00624 accession of C. baccatum showed a susceptible response too, but the symptoms were milder than in other susceptible plants, showing a maximum symptom score of 0.5 . The susceptible accessions showed a maximum symptom index between 0.5 and 3.5 and a mean maximum absorbance between 0.61 and 1.81. CDP00614, CDP05581, CDP07825 and 

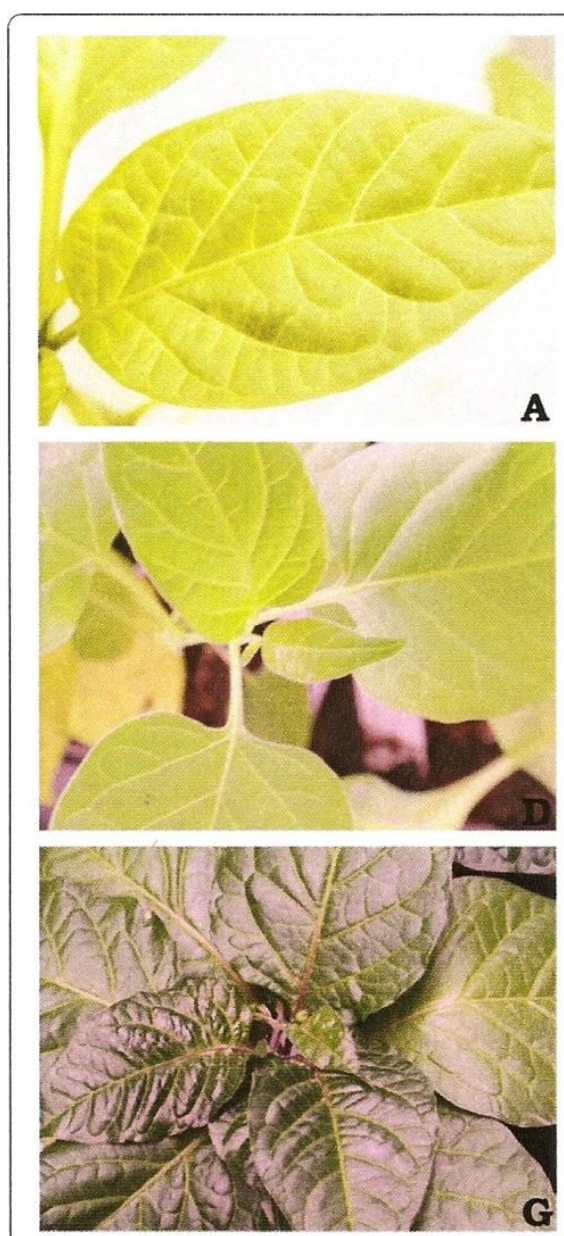
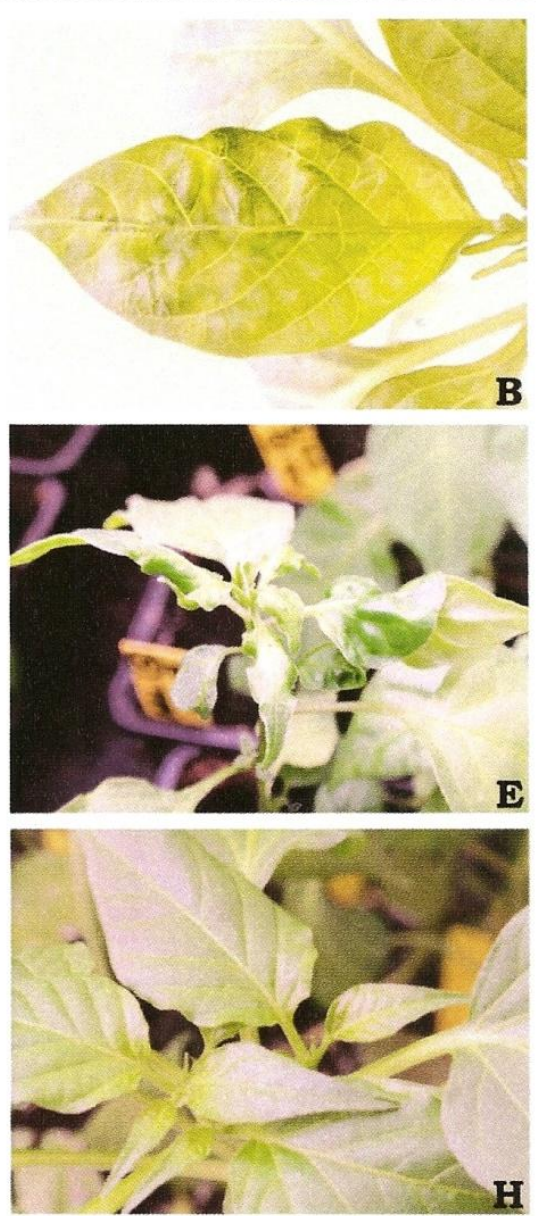
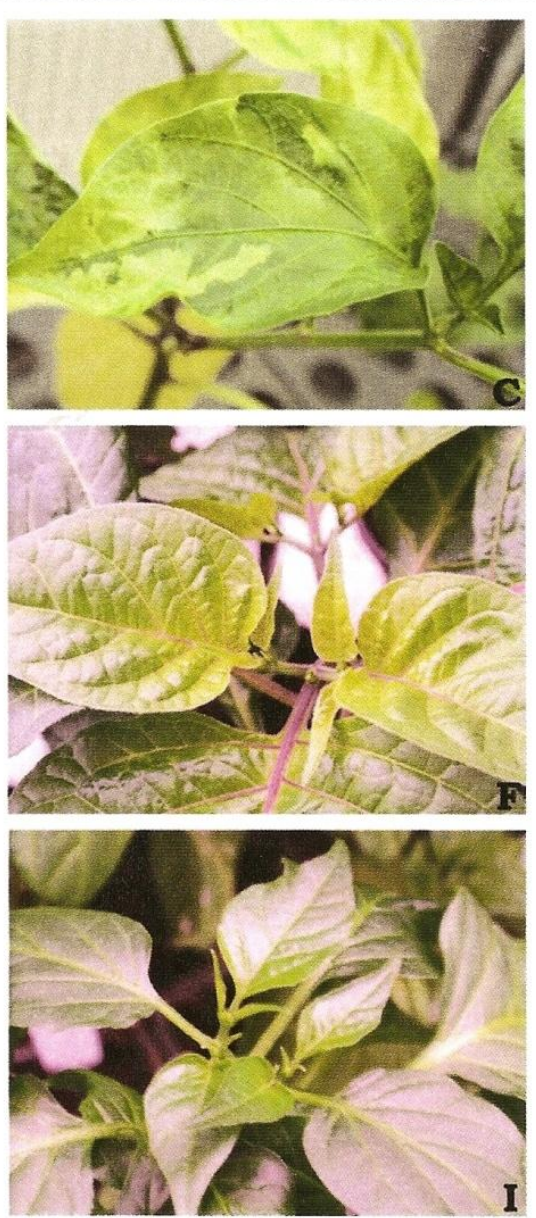

Figure 1 PVY-F14K symptoms in pepper plants and representative resistant accessions. (A) Agridulce negative control leaf at 15 DPI. (B) Agridulce leaf showing mosaic and deformation at 15 DPI. (C) Agridulce leaf showing dark green vein-banding between 45-60 DPI. (D) CDP08791 negative control (C. chacoense) at 45 DPI. (E) CDP08791 susceptible plant showing stunted growth at 45 DPI. (F) CDP02521 negative control (C. chinense) at 60 DPI. (G) CDP02521 resistant plant showing no symptoms at 60 DPI. (H) CDP09688 negative control (C. annuum) at 60 DPI. (I) CDP09688 resistant plant showing no symptoms at $60 \mathrm{DPI}$.

CDP04710 accessions of C. baccatum and CDP06951 of $C$. frutescens showed $100 \%$ systemically infected plants with absorbances higher than the threshold of each accession $\left(\mathrm{A}_{405}=0.068-0.089\right)$ (date not shown), but no symptoms of systemic infection were detected throughout the survey. These accessions were considered tolerant to PVY-F14K. Moreover, CDP06360 of C. baccatum and CDP07700 of C. chinense, which showed $60 \%$ plants with systemic infection without symptoms, were also considered tolerant. Four accessions of C. annuum (CDP06188, CDP09688, CDP06433 and CDP01135), 2 of C. chinense (CDP02521 and CDP08407) and 9 of C. baccatum (CDP06234, CDP04291, CDP02320, CDP04865, CDP07490, CDP04131, CDP09967, CDP09334 and CDP05929) showed the best response; no plants were infected systemically (all showed a DAS-ELISA negative) and no symptoms were detected (Figure 1). These accessions were considered resistant to the F14K isolate of Potato Virus $Y$.

\section{Discussion}

High polymorphism in pepper EcoTILLING platform We developed a cDNA EcoTILLING platform for pepper to search for allelic variants of the $e I F 4 E$ and $e I F$ (iso) $4 E$ genes. 233 accessions from South America and the Canary Islands were selected in their primary $(C$. chinense, C. frutescens, C. pubescens and C. baccatum) or secondary (C. annuum) centres of diversity [5]. Maximum variability is found within these centres of diversity, which has made it possible to find a high polymorphism in the eIF4E and eIF(iso)4E initiation factors.

36 nucleotide changes were detected in the 21 coding sequences of the $I F 4 E$ gene as well as 26 changes in the 17 eIF(iso) $4 E$ sequences. Our results showed that the pepper accessions used are highly variable. It is possible that cultivated peppers have more genetic variability compared to other crops, such as tomato [45]; but it is 
also possible that this high variability is due to our selection, based as it is on the diversity centres as opposed to a worldwide selection. The only other EcoTILLING study with the eIF4E gene done in melon found very low diversity [14]. Only six polymorphic sites were identified in 113 accessions of $C$. melo and one accession of Cucumis africanus $\mathrm{L}$. In spite of the fact that our EcoTILLING assays were only done in exons, our pepper cDNA platform has a high level of polymorphism compared to melon, and is similar to other works that use EcoTILLING in wild or natural species with other genes. Comai et al. used 150 plants of $A$. thaliana and discovered 55 haplotypes in the five loci analysed [6]. In 25 natural variants of Mla in barley, from five to ten point mutations in $451 \mathrm{bp}$ were identified [13]. EcoTILLING has also identified polymorphisms in black cottonwood (Populus trichocarpa T.), and 63 SNPs were identified in 8191 bp [18]. In Vigna radiata L., a total of 131 SNPs and 26 indels in 45 haplotypes from ten primer sets $(6461 \mathrm{bp})$ were detected [19]. In common bean (Phaseolus vulgaris L.), 22 SNPs were identified in 37 EST candidates [21], whereas in 30 accessions of peanut, eight SNPs were identified in an amplicon of 1280 bp [17]. Therefore, our EcoTILLING collection has high genetic variation between selected accessions, which could be very useful for identifying natural variation in other genes related to biotic or abiotic responses and quality.

\section{Variability of elF4E and elF(iso) $4 E$ genes in pepper}

A total of 21 haplotypes of the eIF4E gene and 15 haplotypes of the $\operatorname{eIF(iso)} 4 E$ gene were identified. Although most of the haplotypes were species-specific, eIF4E_B1 was detected in $C$. annuum and $C$. chinense, eIF4E_G1 in C. chinense and $C$. frutescens, eIF4E_F3 was present in all three of these species and $\operatorname{eIF}($ iso $) 4 E_{-} B 1$ was present in C. chinense, C. frutescens and C. eximium. This may be due to the genetic flow between the species of the $C$. annuum complex (C. annuum, $C$. chinense and C. frutescens) [46]. However, in the case of C. eximium, it is likely due to the presence of ancestral haplotypes, as this species does not cross viably with the others [47].

The 21 eIF4E nucleotide sequences coded for 19 different proteins, and the $15 \operatorname{eIF}$ (iso) $4 E$ haplotypes coded for $10 \mathrm{eIF}($ iso) $4 \mathrm{E}$ proteins, 23 of which were new protein variants. In previous works, 10 allelic variants of eIF4E proteins in C. annuum [23,25] and 2 allelic variants in C. chinense [24] that coded for 12 eIF4E proteins were described. The published proteins of $C$. chinense and three of $C$. аnnuиm were also identified by EcoTILLING in our pepper collection. In the case of the eIF(iso) $4 \mathrm{E}$ initiation factor, only 2 proteins in $C$. annuum had been previously described [36]; our eIF(iso) $4 E_{-} C 1$ haplotype was identical to the published allele, pvr6 $\sigma^{+}$. We identified 14 new eIF4E proteins and 9 new eIF(iso)4E proteins in our pepper collection, but alleles and proteins that had already been described were also identified, confirming that our EcoTILLING platform contains a good representation of Capsicum variability.

We detected 24 non-synonymous changes in eIF4E haplotypes and 14 in $\operatorname{eIF}$ (iso) $4 E$. This high number of amino acid substitutions might be due to the selection and co-evolution of virus and host. In fact, Charron et al. described the evidence for co-evolution between eIF4E of $C$. annuum plants and potyviral VPg, as there is a strong evolutionary pressure to resist viral pathogens [25]. Amino acid changes in the central domain of the PVY-VPg protein have been demonstrated to be subject to positive selection [48]. Moreover, the existence of positive selection within the recessive resistance gene eIF4E has already been described in plants [49].

\section{Functionality of new alleles identified by EcoTILLING}

The main objective of EcoTILLING is to isolate useful new haplotypes or alleles in target genes. Thus, the molecular variation in eIF4E and $e I F($ iso) $4 E$ genes could be very useful for identifying new resistance alleles against important viruses in pepper. Among the pepper potyviruses, Potato virus $Y$ is widespread throughout most of the cultivated areas [25]. PVY can be transmitted by many species of aphids, but chemical methods are effective enough to control the vector. Nevertheless, the impact of this virus has increased due to the restriction of phytosanitary treatments. In recent years, resistance alleles for this virus have not been very important in breeding programs, but now, with the treatment reduction, the use of resistant varieties is the most effective way to prevent damage from the virus. Therefore, a screening with PVY-F14K was done to study the response of the new eIF4E and eIF(iso) $4 \mathrm{E}$ proteins discovered. The F14K isolate of PVY completed the viral cycle in some or all accessions of each analysed species, which indicated that resistance is not species-specific.

We analysed the results according to the protein combinations of eIF4E and eIF(iso)4E (see Additional file 4). From analysis of the correlation between proteins and disease resistance, we hypothesised that the eIF(iso) $4 \mathrm{E}$ proteins were not involved in the resistance to PVY as most of the accession responses could be explained by eIF4E proteins. Accessions carrying the proteins eIF4E_C, eIF4E_F, eIF4E_G, eIF4E_J and eIF4E_P generated symptoms, while accessions with the proteins eIF4E_M, eIF4E_L, eIF4E_R and one accession with the eIF4E_Q protein (CDP04710) and another with eIF4E_F (CDP00614) showed systemic infection but were symptomless. Other accessions carrying new eIF4E proteins found in this study (eIF4E_D, eIF4E_H, eIF4E_K, eIF4E_O and eIF4E_N) showed a resistance response as 
the viral infection was not detected throughout the experiment.

When we compared previous results of the published eIF4E proteins, we obtained the expected response in some accessions that contain these eIF4E proteins. Thus, the accessions with eIF4E_E and eIF4E_A proteins did not show systematic infection, like the pvr2 $2^{1}$ and $p v r 2^{2}$ alleles that break the PVY cycle when inoculated $[23,25,48]$. The eIF4E_I protein was identical to the eIF4E protein that carries the pvr1 allele that confers broad-spectrum resistance to strains of PVY [50]. In spite of this, the CDP07700 accession (eIF4E_I protein) showed a tolerant response, as $3 / 5$ of the plants were DAS-ELISA positive without symptoms. Nevertheless, all CDP07700-accession plants blocked viral accumulation at 45 and 60 DPI. Different factors may explain the initial viral accumulation in some plants of this accession, such as environmental or experimental factors (heavy inoculation pressure, development stage, temperature) or distinct responses to different PVY isolates. All accessions that contain the eIF4E_B protein, identical to the pvr2 $2^{+}$susceptible allele $[23,25]$, showed a susceptible response to PVY-F14K, except the CDP09688 accession that did not show PVY systemic infection and in which no symptoms were observed. The resistance response of this accession suggests that it is not related to eIF4E nor to eIF(iso)4E, as accessions that carry the same proteins in homozygosis (eIF4E_B, eIF(iso)4E_C or eIF(iso)4E_D) showed susceptible, tolerant or resistant responses. Thus, this response to PVY could be due to another resistance mechanism.

The CDP06234 accession with the eIF4E_F and eIF (iso)4E_C proteins did not show viral multiplication in all tested plants, unlike the other accession with the same protein variants of both genes, CDP00624. The resistance response of the CDP06234 C. baccatum accession could not be explained by these translation initiation factors. The CDP00614 accession that carries the eIF4E_F and eIF(iso)4E_A proteins showed a different response compared to other accessions with the same eIF4E protein variant. These plants showed systemic infection but were symptomless. Nevertheless, in this case, the combination of eIF4E_F and eIF(iso)4E_A could not be ruled out as no accessions with $\operatorname{IF}$ (iso) 4E_A showed a susceptible response. Moreover, eIF(iso) $4 \mathrm{E} \_$A could also explain the different responses of the accessions with the eIF4E_Q protein, CDP05929 and CDP04710. Nevertheless, this combination hypothesis is unlikely as the eIF(iso) $4 \mathrm{E}$ factor was not related to resistance to PVY in the previous works [23,25] and could only clarify the response of these two latter accessions. In fact, the response of CDP09688, CDP06234, CDP00614 and CDP05929 to PVY-F14K is more easily explained by the presence of another gene or resistant mechanism. For instance, the Pvr4 anonymous locus of the C. annuum line, Criollo de Morelos 334, showed a complete dominant resistance to all PVY pathotypes as well as to Pepper mottle virus [51].

Nine newly identified eIF4E proteins seemed to interact with PVY-F14K, but five new eIF4E variants (D, H, K, N and $\mathrm{O}$ ) were related to resistance response to this virus. The published resistance alleles of pepper carry different combinations of non-conservative amino acid changes that are localised on the surface of eIF4E in regions I (exon 1) and II (exon2) $[25,41]$. The changes in these regions seem to be responsible for resistance at least against PVY [23,25]. Thirteen non-synonymous changes (amino acid positions 15, 65, 73, 77, 131, 160, 213, 214, 216, 218 and 219) of the IF $4 E$ haplotypes analysed by mechanical inoculation in this survey were previously unknown (Table 2). Seven of the mutations detected by EcoTILLING in exons 1 and 2 of the eIF4E gene generate a change of charge. Six mutations are specific to the new resistance alleles and are localised in exon 1 or exon 5 . The published proteins eIF4E_A $\left(p v r 2^{2}\right)$ and eIF4E_E $\left(p v r 2^{1}\right.$ ) have a V67E change (region 1), which is sufficient to compromise PVY infection [25]. eIF4E_N, eIF4E_O and eIF4E_K of $C$. baccatum and eIF4.E_ $\mathrm{H}$ of $C$. chinense have a single amino acid substitution in exon 1 (N65D) which also may prevent multiplication of the virus. Although C. baccatum showed a low susceptibility to PVY-F14K, this mutation may explain the resistance response of some $C$. baccatum accessions. The other resistant protein, eIF4E_D (C. chinense), has other amino acid changes located in regions I (P66T, A73D), II (G107R) and V (L218F). These changes in regions I and II are also present in other resistance or tolerance eIF4E proteins (eIF4E_K and eIF4E_I).

The new alleles of the eIF4E initiation factor have been named pvr2 with a numerical superscript for each new allele based on the latest described allele ( $p v r 2^{9}$ of Chile de Arbol (C. annuum) [25]), using the nomenclature of Kyle and Palloix [50]. The resistance alleles to PVY-F14K, D1, H1, K1, N1 and O1, have been designated as $p v r 2^{10}, p v r 2^{11}, p v r 2^{12}, p v r 2^{13}$ and $p v r 2^{14}$, respectively. The new susceptible or tolerant alleles of the eIF4E gene, C1, G1, R1, J1, L1, M1, P1 and Q1, have been designated as $p v r 2^{15}, p v r 2^{16}, p v r 2^{17}, p v r 2^{18}, p v r 2^{19}$, $p v r 2^{20}, p v r 2^{21}$ and $p v r 2^{22}$, respectively. The new eIF(iso) $4 E$ alleles have been named pvr6 with a numerical superscript for the new allele based on the only resistance allele, pvr6 (Perennial [Genbank: DQ022083] cultivar of C. annuum [36]). Thus, the eIF(iso) $4 E$ alleles that code for a new eIF(iso)4E protein, $A 1, B 1, D 1, E 1, F 1$, $H 1$ and $K 1$, have been designated as $p v r \sigma^{2}, p v r \sigma^{3}, p v r \sigma^{4}$, $p v r 6^{5}, p v r 6^{6}, p v r 6^{7}$ and $p v r 6^{8}$. Finally, the alleles that code for the eIF(iso) $4 E_{-}$G protein (eIF(iso) $4 E_{-} G 1$ and eIF(iso)4E_G2) have been named pvr6 ${ }^{9}$. 
These five new resistant eIF4E alleles, and their possible use in heterozygosis, could make their introgression into new commercial hybrids easier. Moreover, these recessive alleles are excellent allele reserves against the changing nature of viral pathogens, as mutations are required in the $V P g$ gene of the PVY to restore its interaction with the different mutated eIF4E proteins $[25,48]$.

\section{ECoTILLING platform implemented in pepper}

The use of cDNA as starting material for endonucleasebased EcoTILLING has not been previously described. However, the cDNA-based mutation screening has been described using other technologies, such as HRM [52] or DNA sequencing [53]. This strategy has several advantages with respect to EcoTILLING assays based on DNA. Although EcoTILLING is a potent technique for discovering SNPs and examining DNA variation in natural populations, one problem is the amplification of target genes from wild species, due to sequence mispriming [14]. The use of cDNA and primers located in transcribed sequences avoids this problem, as these regions are more conserved. This facilitates the use of sequence data from related and model species. Another advantage is that this system avoids the intron sequence, and the complete CDS can be amplified in one or two reactions. In DNA EcoTILLING, the presence of introns may be a problem as most of the changes will be located in these regions. To avoid this, an exon-by-exon strategy is usually adopted, requiring as many reactions as there are exons in the candidate gene. In contrast, the cDNA EcoTILLING approach reduces the number of PCR and CEL I reactions per sample.

This work is an example of where cDNA EcoTILLING is both cost- and time-effective: it involves different species, only mutations in the CDS are of interest and the genes have several highly variable exons. Another question is the possibility of using oligo-dT in order to transcribe several genes with the same $\mathrm{RT}$ reaction. We used specific primers to improve the efficiency and specificity of the amplification of candidate genes. The expression of the candidate genes in the target tissue has to be previously studied.

One of the essential points of CEL I-based EcoTILLING is the analysis of the band pattern and classification of the samples in relation to it. Some factors may make pattern identification in EcoTILLING assays more difficult. One is experimental variation, as different reactions and denaturing gels make band comparison more difficult. Another factor is the differential mismatch preference shown by the endonuclease, CEL I [9], which may also be influenced by experimental variance, resulting in different band intensity in different samples. It is of note that this preference was not observed by Till et al. using IRDye labelling and the LI-COR system [10]. Some factors depend on target sequence, for if there are several mismatches between the samples and the standard sample, the detection of all internal cuts is difficult because the cDNA is only labelled at the $5^{\prime}$ and $3^{\prime}$ terms. Thus, the presence of several internal cut sites produces weak bands due to partial digestion. Moreover, very close mismatches are very difficult to differentiate by electrophoresis, especially if, due to the number of samples involved, several gels are used. The use of a second standard with a similar or identical sequence reduces these problems and facilitates the correct classification of the samples. These problems, related to accuracy, are not associated with complete CDS amplification; even if the analysis is carried out independently for each exon, it is necessary to use a second standard to detect the presence of very close mutations.

Thus, to confirm our initial classification, the samples were compared to a new related standard. After the second enzyme reaction, the samples were reclassified and the groups reduced to 46 for the $e I F 4 E$ gene and increased to 31 for eIF(iso) $4 E$. Nevertheless, after cDNA sequencing, the groups were reduced to 29 and 17 , respectively. This discrepancy between CEL I groups and sequencing haplotypes is attributable to small differences in band pattern due to experimental variation, the high variability of $e I F 4 E$ and $\operatorname{eIF}$ (iso) $4 E$ genes in the selected accessions and the presence of very close mutations. To minimise rare allele loss we designed our double-test protocol and took into account a large number of weak bands, which increased the false positive rate. This explains why most CEL I groups were represented by one or two accessions and why some of them showed the same sequence. This would also happen if a genomic DNA platform were used. In spite of the number of false positives in our assay, this double test is very efficient in detecting differences between very similar haplotypes. In our analysis, we detected six haplotypes that had been misclassified in the first analysis, one of which resulted in an eIF4E allele resistant to PVY-F14K.

This EcoTILLING platform contains a good representation of Capsicum genetic variability and is easy and efficient to test using CEL I-based protocols. But this collection is also useful in identifying new nucleotide variations using other techniques, such as direct sequencing with new sequencing systems (NGS), high resolution melting (HRM) or sensitive capillary electrophoresis (CSCE). Several new approaches based on these techniques have been published [54-56], and it is very likely that more efficient NGS-based strategies will be developed. For this collection, we have also built up a DNA platform in 96-well format available for use. In this new scenario, our pepper platforms with cDNA and DNA will facilitate and still be useful for the isolation of new mutations and SNPs related to traits useful in the breeding of these species. 


\section{Conclusions}

EcoTILLING has been optimised in different species of pepper and is the first to use cDNA and not genomic DNA; this approach avoids intronic sequence problems and reduces the reaction number. We analysed 233 accessions looking for allelic variants of the eIF4E and eIF(iso) $4 E$ genes. High variability for these initiation factors was detected, which showed a high genetic variation between selected accessions when screened by EcoTILLING. Therefore, genes related to biotic or abiotic responses and quality (pungency level, extractable red colour and flavour) are potential targets using our cDNA or DNA platforms. Five new resistance alleles were identified for PVY, and could be introgressed into commercial pepper cultivars to contribute to a more effective and stable resistance to different PVY isolates. This eIF4E/eIF(iso) $4 E$ haplotype selection is also a source for searching for new resistance alleles in the fight against other viruses.

\section{Methods}

Plant material screening by EcoTILLING

The accessions of Capsicum genus included 30 accessions of C. annuum, 41 of C. chinense, 48 of C. frutescens, 75 of C. baccatum, 35 of C. pubescens, 2 of C. eximium and 2 of $C$. chacoense (see Additional file 1 ). These accessions were obtained from the COMAV genebank and were collected from Bolivia, Ecuador, Chile, Peru and the Canary Islands (Spain). The accessions were selected according to their morphological variability and geographic origin. All seeds were treated with $10 \%(\mathrm{w} / \mathrm{v}) \mathrm{Na}_{3} \mathrm{PO}_{4} \cdot 12 \mathrm{H}_{2} \mathrm{O}$ during 3 hours to prevent viral infection, and with $3 \%(\mathrm{w} / \mathrm{v})$ sodium hypochlorite during $10 \mathrm{~min}$ to sterilise and facilitate germination. A germinated seed from each accession was transferred to a $7 \times 7 \times 6.5 \mathrm{~cm}$ polyethylene pot and grown under greenhouse conditions.

\section{RNA isolation}

RNA extraction from $75 \mathrm{mg}$ of young pepper leaves was carried out with TRI-Reagent protocol (Sigma-Aldrich, Saint Louis, Missouri, USA). Total RNA was determined spectrophotometrically using a Biophotometer (Eppendorf, Hamburgo, Germany) and was stored at $-80^{\circ} \mathrm{C}$. Reverse transcription was carried out with these RNA samples to build up a cDNA-based EcoTILLING platform in 96-well format.

\section{Reverse transcription and amplification}

Specific primers for the amplification of full-length eIF4E ORF were designed according to the published sequence [GenBank: AY122052] (C. annuum); for eIF (iso)4E ORF we used TC5256-EST (TIGR CaGI) ( $C$. annuum). First-strand cDNA was synthesised using
Expand Reverse Transcriptase (Roche, Mannheim, Germany) according to the manufacturer's protocol. RT was performed at $43^{\circ} \mathrm{C}$ for $60 \mathrm{~min}$ using $1 \mu \mathrm{g}$ total RNA and $50 \mathrm{pmol}$ of $3^{\prime}$ UTR specific primers, GTGCCTACAACTTTTCAGTACG for eIF4E gene and CAAGTATTGCTGGAACTTGG for $e I F($ iso $4 E$. These were used to improve the efficiency and specificity of the amplification of candidate genes. The completed open reading frames were amplified by nested PCR. The PCR was performed in a final volume of $50 \mu \mathrm{l}$ from $2.5 \mu \mathrm{l}$ of RT reaction, using DNA polymerase Netzyme (N.E.E.D, Valencia, Spain) and primers from the beginning of the coding part of the eIF4E (ATGGCAACAGCTGAAATGG) and eIF(iso) $4 E$ genes (ATGGCCACCGAAGCACCAC). The reverse primers were those used in the RT reaction. PCR cycling conditions were $94^{\circ} \mathrm{C} 5$ $\min ,\left(94^{\circ} \mathrm{C} 1 \mathrm{~min}, 58^{\circ} \mathrm{C} 30 \mathrm{sec}, 72^{\circ} \mathrm{C} 1 \mathrm{~min}\right)$ for 15 cycles and $72^{\circ} \mathrm{C} 10 \mathrm{~min}$. The second PCR was carried out using the same forward primers, but the reverse primers were CTTATATTCCGACATTGCATC (eIF4E gene) and GAGGGGTCAATCCCACACG (eIF(iso)4E gene). The second PCR was carried out from $2.5 \mu \mathrm{l}$ of each first PCR, using the same conditions as the first PCR but repeated 25 cycles. PCR product was checked by $1 \%$ agarose gel electrophoresis and DNA concentration was estimated by densitometry.

\section{Screening for polymorphisms and sequence}

The celery juice extraction was carried out as described by Till et al. [10]. EcoTILLING reactions were carried out according to the procedure described by Comai et al. [6], with certain modifications. In contrast to standard EcoTILLING procedure, each PCR reaction was performed independently to avoid problems related to differences in the amplification efficiency of target genes from two species in the same reaction. Thus, $100 \mathrm{ng}$ of PCR product from each sample and $100 \mathrm{ng}$ of labelled standard sample were mixed in a final volume of $15 \mu \mathrm{l}$ using 96 well plates. Standard samples were amplified just like normal samples, but using both IRDye-700labelled primers in the nested PCR. These samples were selected as they belonged to the most common group of accessions that were previously tested. DNA duplexes were obtained by heat-denaturing at $95^{\circ} \mathrm{C}$ for $10 \mathrm{~min}$ and cooled slowly to $25^{\circ} \mathrm{C}$ with a rate of $0.1^{\circ} \mathrm{C} / \mathrm{s}$. These duplexes were digested with $5 \mu \mathrm{l}$ of a diluted (1:5) celery extract during $20 \mathrm{~min}$ at $42^{\circ} \mathrm{C}$. EcoTILLING reactions were stopped by adding $2.5 \mu \mathrm{l} 0.5 \mathrm{M}$ EDTA, purified by precipitation with absolute ethanol and $5 \mathrm{M} \mathrm{NaCl}$ and resuspended in $10 \mu \mathrm{l}$ of formamide with bromophenol blue. Reactions were resolved using a LI-COR 4300 DNA Analyzer (Biosciences, Lincoln, Nebraska, USA) with 48 well comb and $0.25 \mathrm{~mm} 6 \%$ acrylamide denaturing gels. The gels were run at $1500 \mathrm{~V}, 40 \mathrm{~W}, 40 \mathrm{~mA}$, 
$45^{\circ} \mathrm{C}$ for $3 \mathrm{~h}$ for the eIF(iso) $4 E$ gene and $3.5 \mathrm{~h}$ for eIF4E. Analysis of the gel images was carried out manually using GIMP 2.4.7 (Free Software Foundation, Boston, Massachusetts, USA). A binary matrix was generated reflecting the presence (1) or absence (0) of each band for each sample. Accessions with no cut bands were assigned to the same group as the standard sample, and those that showed the same band patterns were grouped together. To confirm the first classification, all accessions were compared to a new standard but it was not necessary to perform another PCR for test samples. Thus, an internal standard sample was selected from each large group. However, groups with few samples and similar patterns were reclassified using the same standard. Two LI-COR gel images of the first and second classification are shown (see Additional file 5 and 6). The eIF4E and eIF(iso) $4 E$ genes from one accession of each final group were sequenced from both ends with an ABI PRISM 3100 Avant Genetic Analyzer (Applied Biosystems, Woolston, UK). The sequences were cleaned and assembled using the Staden software package http:// staden.sourceforge.net/staden_home.html. Nucleotide and amino acid sequences were analysed with the EMBOSS package http://emboss.sourceforge.net/. The Clustal X (1.83) algorithm [57] was used to multiple sequence alignments. Haplotypes of heterozygous plants were inferred from different haplotypes sequenced in homozygosis. All sequences were deposited in the EMBL nucleotide database with reference numbers from FN824321 to FN824348 and FN813352 for the eIF4E gene and from FN824349 to FN824364 and FN813353 for the $e I F$ (iso) $4 E$ gene. A plant from each haplotype detected in homozygosis was grown under greenhouse conditions and seeds were obtained by self-pollination.

\section{PVY inoculation procedure}

From each selected haplotype, 4 or 5 plants were tested against the isolate F14K of PVY, kindly provided by Dr. J. Aramburu (IRTA, Cabrils, Spain). Two cultivars of C. annuum (Negral and Agridulce) were used as susceptible controls to PVY. Six days after germination, plants were transferred to $9 \times 9 \times 8 \mathrm{~cm}$ pots in a growth room with controlled environmental conditions: $25 / 18^{\circ} \mathrm{C}$ (day/ night) temperature, $60 / 85 \%$ (day/night) relative humidity, $60-85 \mu \mathrm{mol} \mathrm{s}^{-1} \mathrm{~m}^{-2}$ of irradiance from Sylvania Gro Lux fluorescent tubes and a photoperiod of 14/10 hours (light/darkness).

The inoculum was prepared from reservoir line leaves, Fortuna C of Solanum lycopersicum L. PVY isolate was maintained on this line and transferred to young plants every 4-5 weeks. $2 \mathrm{~g}$ of tissue were ground in $20 \mathrm{ml}$ of inoculation buffer $\left(0.15 \mathrm{M} \mathrm{NaCl}, 3 \mathrm{mM} \mathrm{NaH} \mathrm{PO}_{4}, 75\right.$ $\mathrm{mM} \mathrm{Na}_{2} \mathrm{HPO}_{4}(\mathrm{pH}=7.2-7.4), 1 \%$ polyvinilpirrolidone (PVP) and $0.02 \%, \beta$-mercaptoethanol), to which $1 \%$ active carbon and 1\% carborundum (600 mesh) were added, the latter as an abrasive.

When the fourth leaf was fully expanded, plants were inoculated on all expanded leaves with a cotton-tipped applicator, previously dipped in the inoculum. One negative control from each accession was inoculated only with inoculation buffer. To avoid escapes, one week later the plants were reinoculated on a new fully expanded leaf.

\section{Evaluation and virus detection}

An apical leaf from each plant was collected at 15, 30, 45 and 60 days post inoculation (DPI). Leaf extracts were analysed by DAS-ELISA [58] using a specific antiserum of PVY (Loewe Biochemica GmbH, Sauerlach, Germany) to quantify the PVY-F14K virus. Viral accumulation was tested by the measurement of absorbance at $405 \mathrm{~nm}\left(\mathrm{~A}_{405}\right)$ of the serologic reaction using a Model 550 Microplate Reader (Bio-Rad, Hercules, California, USA). Negative control extracts of each accession were used as negative samples for the ELISA test. A sample was considered positive for PVY (DAS-ELISA positive) when absorbance from the youngest leaf was three times higher than the absorbance mean of its negative control, and was classified as non-infected (DAS-ELISA negative) when the value of absorbance was below this threshold. The negative control mean was calculated for each accession with different time samplings (15, 30, 45 and $60 \mathrm{DPI})$. PVY symptoms on non-inoculated leaves were recorded visually and compared to the respective negative control at the same DPI. A symptom index was assigned to each plant according to the severity of the symptoms (leaf deformation, veinal chlorosis, mosaic, dark green vein-banding and stunted growth). This index ranged from 0 for plants with no symptoms to 4 for dead plants. An accession was considered resistant when no plants were infected systemically and no symptoms were observed, tolerant when showing DAS-ELISA positive in all or some plants but without symptoms and susceptible when DAS-ELISA positive with systematic symptoms. Once the survey ended, all material used in the screening (plants, pots and inoculum solution) were autoclaved at $121^{\circ} \mathrm{C}$ for $30 \mathrm{~min}$ to avoid viral contamination.

\section{Additional material}

Additional file 1: Capsicum spp. accessions analysed by EcoTILLING and their haplotypes elF4E and elF(iso) $4 E$. Accession number, country, species and haplotype variants of the elF $4 E$ and $e I F($ iso) $4 E$ genes for all accessions analysed by EcoTILLING

Additional file 2: Alignment of predicted elF4E proteins from different haplotypes. Alignment using Clustal $X$ of predicted elF4E proteins from different haplotypes detected by EcoTILLING and elF4E protein of $p v r 2^{+}$allele [Genbank: AAM82190]. 
Additional file 3: Alignment of predicted elF(iso)4E proteins from different haplotypes. Alignment using Clustal $X$ of predicted eIF(iso)4E proteins from different haplotypes detected by EcoTILLING and elF(iso)4E protein of $p v r 6^{+}$allele [Genbank: AAY62609].

Additional file 4: Analysis to determine that translation initiation factor is involved in PVY resistance. Response of the tested accessions against PVY-F14K according to their elF4E and elF(iso)4E proteins. Resistant accessions are highlighted in green, tolerant accessions in yellow and susceptible accessions in red.

Additional file 5: EcoTILLING gel image of first classification made to $e I F$ (iso) $4 E$ gene. Mutation detection of elF(iso) $4 E$ gene in a gel image from IRD700 channel of LI-COR analyser, using CDP06433 sample as reference. Numbers on the left indicate the molecular weight marker in bp. (*) Self-hybridised reference sample.

\section{Additional file 6: EcoTILLING gel image of second classification} made to elF4E gene. Mutation detection of elF4E gene in a gel image from IRD700 channel of LI-COR analyser, using CDP006188 sample of initial group 1 as reference. Numbers on the left indicate the molecular weight marker in bp. Numbers on the top indicate the EcoTILLING group after the first classification. (S) Self-hybridised reference sample. $\left(^{*}\right)$ Two accessions classified in group 2 or 3 after the first classification showing the same band pattern. (\#) Two accessions classified in group 2 or 4 after the first classification showing the same band pattern.

\section{Acknowledgements}

VPI is the recipient of an FPU fellowship of the Ministerio de Educación y Ciencia. The authors thank J. Aramburu and C. Lopez for kindly providing the PVY-F14K isolate. We also thank J. Blanca and L. Pascual for their critical readings of the manuscript. The help of Joshua Bergen in improving the English of this manuscript is gratefully acknowledged.

\section{Authors' contributions}

VPI obtained the experimental data. JC designed the study and the experiments. VPI, FN and JC analysed the data and prepared the manuscript. All authors read and approved the final manuscript.

\section{Received: 7 June 2010 Accepted: 12 November 2010}

Published: 12 November 2010

\section{References}

1. DeWitt D, Bosland PW: The pepper garden. Berkeley, CA, Ten Speed Press; 1993.

2. Nuez F, Gil R, Costa J: El cultivo de pimientos, chiles y ajies Madrid, Ediciones Mundi-Prensa; 1996

3. Boukema IW: Allelism of genes-controlling resistance to TMV in Capsicum L. Euphytica 1980, 29(2):433-439.

4. Moury B, Palloix A, Selassie KG, Marchoux G: Hypersensitive resistance to Tomato spotted wilt virus in three Capsicum chinense accessions is controlled by a single gene and is overcome by virulent strains. Euphytica 1997, 94(1):45-52.

5. Crosby KM: Pepper. In Vegetables II. Volume 2. Edited by: Prohens J, Nuez F, Carena MJ. New York: Springer; 2008:221-248.

6. Comai L, Young K, Till BJ, Reynolds SH, Greene EA, Codomo CA, Enns LC Johnson JE, Burtner C, Odden AR, Henikoff S: Efficient discovery of DNA polymorphisms in natural populations by EcoTILLING. Plant Journal 2004, 37(5):778-786

7. Colbert T, Till BJ, Tompa R, Reynolds S, Steine MN, Yeung AT, McCallum CM, Comai L, Henikoff S: High-Throughput Screening for Induced Point Mutations. Plant Physiology 2001, 126(2):480-484.

8. Till BJ, Reynolds SH, Greene EA, Codomo CA, Enns LC, Johnson JE, Burtner C, Odden AR, Young K, Taylor NE, Henikoff JG, Comai L, Henikoff S: Large-scale discovery of induced point mutations with high-throughput TILLING. Genome Research 2003, 13(3):524-530.

9. Oleykowski CA, Mullins CRB, Godwin AK, Yeung AT: Mutation detection using a novel plant endonuclease. Nucleic Acids Research 1998, 26(20):4597-4602.
10. Till BJ, Burtner C, Comai L, Henikoff S: Mismatch cleavage by single-strand specific nucleases. Nucleic Acids Research 2004, 32(8):2632-2641.

11. Triques K, Piednoir E, Dalmais M, Schmidt J, Le Signor C, Sharkey M, Caboche $M$, Sturbois B, Bendahmane A: Mutation detection using ENDO1: Application to disease diagnostics in humans and TILLING and EcoTILLING in plants. BMC Molecular Biology 2008, 9:9.

12. Kadaru SB, Yadav AS, Fjellstrom RG, Oard JH: Alternative Ecotilling Protocol for Rapid, Cost-Effective Single-Nucleotide Polymorphism Discovery and Genotyping in Rice (Oryza sativa L.). Plant Molecular Biology Reporter 2006, 24(1):3-22.

13. Mejlhede N, Kyjovska Z, Backes G, Burhenne K Rasmussen SK, Jahoor A ECOTILLING for the identification of allelic variation in the powdery mildew resistance genes mlo and Mla of barley. Plant Breeding 2006, 125(5):461-467.

14. Nieto C, Piron F, Dalmais M, Marco CF, Moriones E, Gomez-Guillamon ML, Truniger V, Gomez P, Garcia-Mas J, Aranda MA, Bendahmane A: EcoTILLING for the identification of allelic variants of melon elF4E, a factor that controls virus susceptibility. BMC Plant Biology 2007, 7.

15. Wang J, Sun JZ, Liu DC, Yang WL, Wang DW, Tong YP, Zhang AM: Analysis of Pina and Pinb alleles in the micro-core collections of Chinese wheat germplasm by Ecotilling and identification of a novel Pinb allele. Journal of Cereal Science 2008, 48(3):836-842.

16. Ramos ML, Huntley JJ, Maleki SJ, Ozias-Akins P: Identification and characterization of a hypoallergenic ortholog of Ara h 2.01. Plan Molecular Biology 2009, 69(3):325-335.

17. Wang GX, Tan MK, Suj ARC, Saitoh H, Terauchi R, Imaizumi T, Ohsako T, Tominaga T: Discovery of single-nucleotide mutations in acetolactate synthase genes by Ecotilling. Pesticide Biochemistry and Physiology 2007, 88(2):143-148.

18. Gilchrist EJ, Haughn GW, Ying CC, Otto SP, Zhuang J, Cheung D, Hamberger B, Aboutorabi F, Kalynyak T, Johnson L, Bohlmann J, Ellis BE, Douglas CJ, Cronk QCB: Use of Ecotilling as an efficient SNP discovery tool to survey genetic variation in wild populations of Populus trichocarpa. Molecular Ecology 2006, 15(5):1367-1378.

19. Barkley NA, Wang ML, Gillaspie AG, Dean RE, Pederson GA, Jenkins TM: Discovering and verifying DNA polymorphisms in a mung bean $V$. radiata (L.) R. Wilczek collection by EcoTILLING and sequencing. BMC Res Notes 2008, 1:28.

20. Elias R, Till BJ, Mba C, Al-Safadi B: Optimizing TILLING and Ecotilling techniques for potato (Solanum tuberosum L). BMC Res Notes 2009, 2:141.

21. Galeano CH, Gomez M, Rodriguez LM, Blair MW: CEL I Nuclease Digestion for SNP Discovery and Marker Development in Common Bean (Phaseolus vulgaris L.). Crop Science 2009, 49(2):381-394.

22. Browning KS, Webster C, Roberts JKM, Ravel JM: Identification of an Isozyme Form of Protein-Synthesis Initiation-Factor $4 \mathrm{~F}$ in Plants. Journal of Biological Chemistry 1992, 267(14):10096-10100.

23. Ruffel S, Dussault MH, Palloix A, Moury B, Bendahmane A, Robaglia C, Caranta $C$ : A natural recessive resistance gene against Potato virus $Y$ in pepper corresponds to the eukaryotic initiation factor $4 \mathrm{E}$ (elF4E). Plant Journal 2002, 32(6):1067-1075.

24. Kang BC, Yeam I, Frantz JD, Murphy JF, Jahn MM: The pvr 1 locus in Capsicum encodes a translation initiation factor elF $4 \mathrm{E}$ that interacts with Tobacco etch virus VPg. Plant Journal 2005, 42(3):392-405

25. Charron C, Nicolai M, Gallois U, Robaglia C, Moury BT, Palloix A, Caranta C: Natural variation and functional analyses provide evidence for coevolution between plant elF4E and potyviral VPg. Plant Journal 2008, 54(1):56-68.

26. Murphy JF, Blauth JR, Livingstone KD, Lackney VK, Jahn MK: Genetic mapping of the pvr 1 locus in Capsicum spp. and evidence that distinct potyvirus resistance loci control responses that differ at the whole plant and cellular levels. Molecular Plant-Microbe interactions 1998, 11(10):943-951.

27. Parrella G, Ruffel S, Moretti A, Morel C, Palloix A, Caranta C: Recessive resistance genes against potyviruses are localized in colinear genomic regions of the tomato (Lycopersicon spp.) and pepper (Capsicum spp.) genomes. Theoretical and Applied Genetics 2002, 105(6-7):855-861.

28. Ruffel S, Gallois UL, Lesage ML, Caranta C: The recessive potyvirus resistance gene pot- 1 is the tomato orthologue of the pepper pvr2-elf4E gene. Molecular Genetics and Genomics 2005, 274(4):346-353.

29. Nicaise V, German-Retana S, Sanjuan R, Dubrana MP, Mazier M, Maisonneuve B, Candresse T, Caranta C, Le Gall O: The eukaryotic 
translation initiation factor $4 \mathrm{E}$ controls lettuce susceptibility to the potyvirus Lettuce mosaic virus. Plant Physiology 2003, 132(3):1272-1282.

30. Gao ZH, Johansen E, Eyers S, Thomas CL, Noel Ellis TH, Maule AJ: The potyvirus recessive resistance gene, $s b m$ l, identifies a novel role for translation initiation factor elF4E in cell-to-cell trafficking. Plant journal 2004, 40(3):376-385.

31. Bruun-Rasmussen M, Moller IS, Tulinius G, Hansen JKR, Lund OS, Johansen IE: The same allele of translation initiation factor $4 E$ mediates resistance against two potyvirus spp. in Pisum sativum. Molecular PlantMicrobe Interactions 2007, 20(9):1075-1082

32. Ling K-S, Harris KR, Meyer JDF, Levi A, Guner N, Wehner TC, Bendahmane A Havey MJ: Non-synonymous single nucleotide polymorphisms in the watermelon elF4E gene are closely associated with resistance to Zucchini yellow mosaic virus. Theor Appl Genet 2009, 120(1):191-200.

33. Kanyuka K, Druka A, Caldwell DG, Tymon A, McCallum N, Waugh R, Adams MJ: Evidence that the recessive bymovirus resistance locus rym 4 in barley corresponds to the eukaryotic translation initiation factor $4 \mathrm{E}$ gene. Molecular Plant Pathology 2005, 6(4):449-458

34. Naderpour $M$, Lund OS, Larsen $R$, Johansen E: Potyviral resistance derived from cultivars of Phaseolus vulgaris carrying $b c-3$ is associated with the homozygotic presence of a mutated elF4E allele. Molecular Plant Pathology 2010, 11(2):255-263.

35. Lellis AD, Kasschau KD, Whitham SA, Carrington JC: Loss-of-susceptibility mutants of Arabidopsis thaliana reveal an essential role for elF(iso)4E during Potyvirus infection. Current Biology 2002, 12(12):1046-1051.

36. Ruffel S, Gallois J,, Moury B, Robaglia C, Palloix A, Caranta C: Simultaneous mutations in translation initiation factors elF $4 E$ and $\mathrm{elF}$ (iso) $4 \mathrm{E}$ are required to prevent Pepper veinal mottle virus infection of pepper. Journal of General Virology 2006, 87:2089-2098

37. Rubio M, Nicolai M, Caranta C, Palloix A: Allele mining in the pepper gene pool provided new complementation effects between pvr2-elF4E and pvr6-elf(iso) 4 E alleles for resistance to Pepper veinal mottle virus. Journal of General Virology 2009, 90:2808-2814

38. Hwang J, Li J, Liu WY, An SJ, Cho H, Her N, Yeam I, Kim D, Kang BC: Double mutations in elF4E and eIFiso4E confer recessive resistance to Chilli veinal mottle virus in pepper. Molecules and Cells 2009, 27(3):329-336.

39. Yoshii M. Nishikiori M, Tomita K, Yoshioka N, Kozuka R, Naito S, Ishikawa M: The Arabidopsis Cucumovirus multiplication 1 and 2 loci encode tip translation initiation factors 4E and 4G. Journal of Virology 2004, 78(12):6102-6111.

40. Albar L, Bangratz-Reyser M, Hebrard E, Ndjiondjop MIN, Jones M Ghesquiere A: Mutations in the elF(iso) $4 G$ translation initiation factor confer high resistance of rice to Rice yellow mottle virus. Plant Journal 2006, 47(3):417-426.

41. Robaglia C, Caranta C: Translation initiation factors: a weak link in plant RNA virus infection. Trends in Plant Science 2006, 11(1):40-45.

42. Dreher TW, Miller WA: Translational control in positive strand RNA plant viruses. Virology 2006, 344(1):185-197.

43. Pickersgill B: Genetic resources and breeding of Capsicum spp. Euphytica 1997, 96(1):129-133

44. Ruffel S, Caranta C, Palloix A, Lefebvre V, Caboche M, Bendahmane A: Structural analysis of the eukaryotic initiation factor $4 \mathrm{E}$ gene controlling potyvirus resistance in pepper: exploitation of a BAC library. Gene 2004, 338(2):209-216, 129-133.

45. Miller JC, Tanksley SD: RFLP analysis of phylogenetic-relationships and genetic-variation in the genus Lycopersicon. Theoretical and Applied Genetics 1990, 80(4):437-448.

46. Ince AG, Karaca M, Onus AN: Genetic Relationships Within and Between Capsicum Species. Biochemical Genetics 2010, 48(1-2):83-95

47. Pickersgill B: Some aspects of interespecific hybridization in Capsicum Nth Eucarpia Capsicum Meeting: 14-16 October 1980; Wageningen 1980, 2-6.

48. Moury B, Morel C, Johansen E, Guilbaud L, Souche S, Ayme V. Caranta C, Palloix A, Jacquemond $M$ : Mutations in Potato virus $Y$ genome-linked protein determine virulence toward recessive resistances in Capsicum annuum and Lycopersicon hirsutum. Molecular Plant-Microbe Interactions 2004, 17(3):322-329.

49. Cavatorta JR, Savage AE, Yeam I, Gray SM, Jahn MM: Positive Darwinian Selection at Single Amino Acid Sites Conferring Plant Virus Resistance. Journal of Molecular Evolution 2008, 67(5):551-559.

50. Kyle MM, Palloix A: Proposed revision of nomenclature for potyvirus resistance genes in Capsicum. Euphytica 1997, 97(2):183-188.
51. Dogimont C, Palloix A, Daubze AM, Marchoux G, Selassie KG, Pochard E: Genetic analysis of broad spectrum resistance to potyviruses using doubled haploid lines of pepper (Capsicum annuum L). Euphytica 1996, 88(3):231-239.

52. Hofinger $B J$, Jing $H C$, Hammond-Kosack KE, Kanyuka K: High-resolution melting analysis of CDNA-derived PCR amplicons for rapid and costeffective identification of novel alleles in barley. Theoretical and Applied Genetics 2009, 119(5):851-865.

53. Novaes E, Drost DR, Farmerie WG, Pappas GJ, Grattapaglia D, Sederoff RR, Kirst M: High-throughput gene and SNP discovery in Eucalyptus grandis, an uncharacterized genome. BMC Genomics 2008, 9:14.

54. Dong CM, Vincent K, Sharp P: Simultaneous mutation detection of three homoeologous genes in wheat by High Resolution Melting analysis and Mutation Surveyor (R). BMC Plant Biology 2009, 9.

55. Gady ALF, Hermans FWK, Van de Wal M, van Loo EN, Visser RGF, Bachem CWB: Implementation of two high through-put techniques in a novel application: detecting point mutations in large EMS mutated plant populations. Plant Methods 2009, 5.

56. Rigola D, van Oeveren J, Janssen A, Bonne A, Schneiders $H$, van der Poel HJA, van Orsouw NJ, Hogers RCJ, de Both MTJ, van Eijk MJT: HighThroughput Detection of Induced Mutations and Natural Variation Using KeyPoint (TM) Technology. Plos One 2009, 4(3).

57. Higgins DG, Thompson JD, Gibson TJ: Using CLUSTAL for multiple sequence alignments. Computer Methods for Macromolecular Sequence Analysis 1996, 266:383-402.

58. Clark MF, Adams AN: Characteristics of microplate method of enzymelinked immunosorbent assay for detection of plant-viruses. Journal of General Virology 1977, 34(MAR):475-483.

doi:10.1186/1471-2164-11-63

Cite this article as: Ibiza et al: EcoTILLING in Capsicum species: searching for new virus resistances. BMC Genomics 2010 11:631.

\section{Submit your next manuscript to BioMed Central and take full advantage of:}

- Convenient online submission

- Thorough peer review

- No space constraints or color figure charges

- Immediate publication on acceptance

- Inclusion in PubMed, CAS, Scopus and Google Scholar

- Research which is freely avallable for redistribution 

Exploiting the potential of pepper germplasm to identify new tolerance alleles of the $e I F 4 E$ gene against Tobacco etch virus 

Exploiting the potential of pepper germplasm to identify new tolerance alleles of the eIF4E gene against Tobacco etch virus

Vicente Pascual Ibiza, Fernando Nuez and Joaquín Cañizares ${ }^{\#}$

Instituto de Conservación y Mejora de la Agrodiversidad Valenciana (COMAV), Universitat Politècnica de València, 8E CPI, Camino de Vera s/n, 46022 Valencia, Spain

\# Corresponding author

Email addresses:

VPI: viibgi@upvnet.upv.es

FN: fnuez@btc.upv.es

JC: jcanizares@upv.es 


\section{Abstract}

This work reports the response of 35 Capsicum spp. accessions to Tobacco etch virus in order to identify new resistance sources that may be useful to pepper breeders. These accessions were previously selected by the EcoTILLING technique and contain 18 alleles of the eIF4E gene and 7 of eIF(iso)4E. Tobacco etch virus is one of the most aggressive virus diseases that affects peppers, and every year it causes severe yield reductions. Nevertheless, only two alleles of the eIF4E gene have been described as conferring resistance to TEV: $p v r l$ and $p v r 2^{2}$. Our results show that five new eIF4E alleles are related to TEV-tolerance responses. The accessions that contain the $p v r 2^{10}$, $p v r 2^{11}, p v r 2^{12}, p v r 2^{13}$ or $p v r 2^{14}$ alleles did not block virus replication as well as the accessions with $p v r 1$ or $p v r 2^{2}$. These tolerant accessions were symptomless or displayed slight symptoms on leaves, but their fruits showed no symptoms. The eIF4E proteins that coded for $p v r 2^{11}, p v r 2^{12}, p v r 2^{13}$ and $p v r 2^{14}$ have an amino acid substitution in exon 1 (N65D) that may compromise the TEV cycle. In contrast, the combination of several mutations could explain the tolerant response of the $p v r 2^{10}$ allele. The recessive resistance conferred by these new alleles could be used by breeders to obtain a more effective and stable resistance to different TEV isolates.

Keywords Capsicum $\cdot$ EcoTILLING $\cdot$ eIF4E gene $\cdot$ Potyvirus $\cdot$ resistance $\cdot$ TEV 


\section{Introduction}

The Capsicum genus includes five species cultivated around the world: Capsicum annuum L., Capsicum chinense J., Capsicum frutescens L., Capsicum baccatum L. and Capsicum pubescens R. \& P. Nevertheless, sweet cultivars of $C$. annuum are the most consumed, and are the main objective of most breeding programs (Nuez et al. 1996). Viral diseases cause economic losses and are difficult to control, making the identification of new resistance sources one of the main objectives of breeders. Peppers are infected by more than 20 viruses, which are the main limiting factor in their production (Green and Kim 1991). In addition to their commercial exploitation, $C$. chinense, C. frutescens, C. baccatum and C. pubescens are good resistance sources for the breeding of $C$. annuum. For instance, resistance to Tobacco mosaic virus, identified in C. frutescens, C. chinense and Capsicum chacoense H. (Boukema 1980), has been employed to develop modern $C$. annuum cultivars, while the $T s w$ gene, involved in resistance to Tomato spotted wilt virus (Moury et al. 1997), was introgressed from $C$. chinense.

Tobacco etch virus (TEV) is a member of the Potyvirus genus, which includes some of the most aggressive pathogens of pepper (Deom et al. 1997) and comprises $30 \%$ of all known plant viruses (Ward and Shukla 1991). TEV is one of the most damaging viruses in the United States of America (Black et al. 1991), but it has also been detected along the Mediterranean coast of Turkey (Yilmaz et al. 1983), and has become one of the most widespread diseases (Buzkan et al. 2006). This aphid-transmitted virus nonpersistently causes distortion and mosaic on leaves, deformation and discoloration in fruits as well as plant stunting, causing severe yield reductions. TEV can cause wilting by root necrosis, as was described in Tabasco pepper (Ghabrial and Pirone 1967).

TEV is constituted by a single-stranded RNA of $(+)$ polarity that is translated into a 
polyprotein which is subsequently cleaved into up to ten smaller peptides (Riechmann et al. 1992). Potyviral RNA is covalently linked to a viral protein, VPg (genome-linked protein), which is an analog of the cap structure of mRNAs (Riechmann et al. 1992). Interaction between the host translation initiation factors eIF4E or eIF(iso)4E and $\mathrm{VPg}$ is necessary to initiate and complete the viral infection of many members of the genus Potyvirus (Leonard et al. 2000; Schaad et al. 2000). eIF4E associates with eIF4G to form the eIF4F cap-binding complex. An isoform of eIF4F (eIF(iso)4F) that consists of eIF(iso)4E and eIF(iso)4G subunits has been identified (Browning et al. 1992).

The cloning of genes that confer recessive resistance to potyviruses has shown that they code for the eukaryotic translation initiation factors, eIF4E and eIF(iso)4E. In Solanaceae, the alleles pvr2 (C. annuum), pvrl (C. chinense) and pot-1 (Solanum habrochaites $\mathrm{S}$.), which confer resistance to Potato virus $Y$ (PVY) and to several strains of TEV, code for the eIF4E factor (Ruffel et al. 2002; Ruffel et al. 2005; Kang et al. 2005). In other crops, mutant alleles of the eIF4E gene inhibit the multiplication of different members of the Potyviridae family (reviewed by Truniger and Aranda 2009). Other examples are alleles created via mutagenesis at the lspl locus of Arabidopsis thaliana L., which confer resistance to Turnip mosaic virus, and code for the eIF(iso)4E factor (Lellis et al. 2002). In pepper, simultaneous mutations in the eIF4E and eIF(iso)4E genes confer resistance to Pepper veinal mottle virus (PVMV) (Ruffel et al. 2006; Rubio et al. 2009) and Chilli veinal mottle virus (ChiVMV) (Hwang et al. 2009). There are examples of mutations in the eIF4E factor that confer resistance to other viral families, such as to Melon necrotic spot virus (family Tombusviridae) in melon (Nieto et al. 2007). It is clear that an interruption of viral infection can result when a host factor is modified (Fraser 1990). Some mutations in these translation initiation factors break the potyvirus cycle due to the alteration of the VPg binding function (Kang et al. 2005; 
Yeam et al. 2007), which blocks virus replication. Therefore, these genes are potential targets to search for new resistant sources and to identify resistance alleles to effectively combat the appearance of new isolates.

Developing resistant cultivars is the most effective way to reduce the impact of viral diseases, but it requires a continuous effort as the emergence of new virus isolates that can overcome resistances are continuously produced. In recent years, the development of Integrated Pest Management to reduce the use of pesticides has increased the impact of insect-transmitted viruses, which in turn has required the use and development of new resistant varieties. In spite of the many mutated $e I F 4 E$ alleles that induce resistance to various PVY isolates, in pepper, only two eIF4E alleles are resistant to TEV: pvrl and $p v r 2^{2}$ (Kang et al. 2005; Charron et al. 2008). Genebank screening is the main approach for identifying new resistant sources. Nevertheless, it is a laborious and expensive task as it is necessary to invest large amounts of work, time and money into the inoculation with the pathogen, the assessment of symptoms and the quantification of the pathogen. The EcoTILLING technique is an alternative approach for exploiting genebanks more efficiently. This technique facilitates the identification of natural polymorphisms (SNPs or small indels) in target genes (Comai et al. 2004). EcoTILLING was used in 233 accessions of the COMAV (Instituto de Conservación y Mejora de la Agrodiversidad Valenciana) genebank to look for allelic variants of eIF4E and eIF(iso)4E genes in different Capsicum species (Ibiza et al. 2010). A small collection of 31 accessions that includes different eIF4E / eIF(iso)4E combinations was created.

The main objective of this study was to evaluate the accessions that carry the new $e I F 4 E$ and $e I F(i s o) 4 E$ alleles for resistance to TEV in order to increase the resistance alleles against one of the most destructive viruses in pepper. Five new resistance alleles 
of the $e I F 4 E$ gene were detected. These new alleles confer effective resistance, and could be used to develop new commercial pepper cultivars and contribute to a more stable resistance to different TEV isolates than any dominant resistance genes.

\section{Materials and methods}

\section{Plant material}

We evaluated 35 accessions of the genus Capsicum: 8 of $C$. annuum, 5 of $C$. chinense, 5 of $C$. frutescens, 15 of $C$. baccatum, 1 of $C$. pubescens and 1 of $C$. chacoense. These accessions contain 31 combinations of 18 eIF4E alleles and 7 eIF(iso) $4 E$ alleles (Ibiza et al. 2010).

To prevent viral infection, all the seeds were treated with $10 \%(\mathrm{w} / \mathrm{v})$ solution of trisodium phosphate $\left(\mathrm{Na}_{3} \mathrm{PO}_{4} \cdot 12 \mathrm{H}_{2} \mathrm{O}\right)$ for 3 hours, followed by a treatment with $3 \%$ $(\mathrm{w} / \mathrm{v})$ sodium hypochlorite for $10 \mathrm{~min}$ to sterilize them and facilitate their germination. Six days after germination in Petri dishes, the plants were transferred to $9 \times 9 \times 8 \mathrm{~cm}$ pots with organic substrate (Humin substrat N3, Neuhause, Germany) and carried to a plant growth chamber. The environmental conditions consisted in $25 / 18^{\circ} \mathrm{C}$ (day/night) temperature, $60 / 85 \%$ (day/night) relative humidity and $60-85 \mu \mathrm{mol} \mathrm{s}^{-1} \mathrm{~m}^{-2}$ of irradiance from Sylvania Gro-Lux fluorescent tubes with a photoperiod of 14/10 hours (light/darkness).

\section{Virus material}

The pTEV-7DA infectious clone [GeneBank: DQ986288], kindly provided by Dr. J.A. Daròs (IBMCP, Valencia, Spain), was used for the screening. This clone was maintained in plants of the susceptible reservoir line Fortuna C (Solanum lycopersicum L.) and was transferred to young plants by mechanical inoculation every 4-5 weeks to maintain optimum virulence. These plants were grown under controlled phytosanitary 
conditions in a growth chamber with cages covered with aphid-proof screens of 32 mesh to avoid virus dissemination.

\section{Mechanical inoculation}

TEV inoculum was prepared from $2 \mathrm{~g}$ of infected reservoir line leaf tissue that were ground in $20 \mathrm{ml}$ of cold inoculation buffer $\left(0.15 \mathrm{M} \mathrm{NaCl}, 3 \mathrm{mM} \mathrm{NaH}{ }_{2} \mathrm{PO}_{4}, 75 \mathrm{mM}\right.$ $\mathrm{Na}_{2} \mathrm{HPO}_{4}(\mathrm{pH}=7.2-7.4), 1 \%$ polyvinilpirrolidone (PVP), $0.02 \%, \beta$-mercaptoethanol). Active carbon (1\%) and carborundum (1\%,600 mesh) were added to the inoculum, the latter as an abrasive.

To test the reproducibility of the data, most of the mutations were analysed in at least two different accessions, sometimes from different species. Four to five plants for each accession carrying known $e I F 4 E$ and $e I F(i s o) 4 E$ sequences were tested. Pepper plants were inoculated at the four true-leaf stage of development. Inoculum was applied on all fully expanded leaves with a cotton-tipped applicator, previously dipped in the inoculum. The plants were reinoculated on a new fully expanded leaf eight days later in order to prevent escapes. One mock control from each accession was inoculated only with inoculation buffer. One negative control of each accession was not inoculated to detect the effects caused by cultivation in the growth chamber unrelated to the inoculation. Two cultivars of $C$. annuum were used as susceptible controls to TEV, Negral and Agridulce.

We monitored the possibility of unintended insects approximately once a week. No insects were identified throughout the study. Virus maintenance and screening were conducted in a controlled-access growth chamber at the Polytechnic University of Valencia under strict phytosanitary measures. To prevent any viral contamination, all material used in the screening (plants, substrate, pots, inoculum solution and laboratory glassware) was autoclaved when the survey ended. The growth chamber was disinfected 
with a solution of trisodium phosphate $(10 \% \mathrm{w} / \mathrm{v})$.

\section{Evaluation and virus detection}

A sample of a non-inoculated apical leaf of each plant was collected at 15, 30, 45 and 60 days post-inoculation (DPI). To quantify the viral accumulation, leaf extracts were tested by DAS-ELISA (Clark and Adams 1977) using a TEV-specific polyclonal antiserum (DSMZ, Braunschweig, Germany). Absorbance after the serologic reaction was measured at $405 \mathrm{~nm}\left(\mathrm{~A}_{405}\right)$ using a Model 550 Microplate Reader (Bio-Rad, Hercules, California, USA). Mock control extracts of each accession were used as negative samples for the ELISA test. The DAS-ELISA result of a sample was considered positive when the absorbance value was greater than three times the absorbance mean of its ELISA negative control, and was classified as non-infected (DAS-ELISA-negative) when the absorbance value was below this threshold. The negative sample mean was calculated for each accession with different time samplings $(15,30,45$ and 60 DPI).

In all plants, TEV symptoms were visually recorded and compared to the respective negative and mock controls at the same DPI. At first, affected pepper plants show veinal clearing, followed by foliar mosaic and leaf deformation. These symptoms may be followed by vein banding (broad dark green bands along the veins), and, finally, susceptible plants may display stunted growth. A symptom index was assigned to each plant according to the severity of the symptoms identified. This index ranged from 0 for plants with none of these symptoms to 4 for plants with severe symptoms ( 1 for slight symptoms, 2 for moderate symptoms and 3 for strong symptoms). The plants were monitored to determine the presence of veinal clearing on inoculated and apical leaves at 7 days after first inoculation; the other symptoms were scored at 7, 15, 30, 45 and 60 days after second inoculation (DPI) on non-inoculated leaves. An accession was 
considered resistant when no plants were infected systemically and no symptom was observed, tolerant when all plants were DAS-ELISA-positive with no or slight symptoms, moderately tolerant when all plants were DAS-ELISA-positive and the symptoms were moderate and susceptible when all plants were DAS-ELISA-positive and the symptom index ranged from moderate to severe.

To evaluate whether fruit development was affected by Tobacco etch virus, plants of selected accessions were transferred to $15 \times 15 \times 15 \mathrm{~cm}$ pots and were kept in the same growth chamber with identical environmental conditions. Supplemental irrigations with nutrient solution were supplied as required. TEV symptoms on plants were visually recorded and compared to the respective mock and negative controls at 20, 40, 60 and 90 days after transplant (DAT). Fruits were observed to confirm the presence or absence of symptoms.

\section{Sequence alignment}

We used Clustal X (Higgins et al. 1996) to do a multiple sequence alignment to identify amino acid substitutions of the eIF4E protein responsible for response to TEV in each analysed accession. The accession codes of the eIF4E proteins of the Capsicum accessions tested in our survey are: EMBL [FN824339 (pvrl), FN824322 (pvrl $\left.{ }^{+}\right)$, FN824321 $\left(p v r 2^{+}\right), \quad$ FN824324 $\left(p v r 2^{1}\right), \quad$ FN813352 $\left(p v r 2^{2}\right)$, FN824323 $\left(p v r 2^{10}\right)$, FN824334 $\left(p v r 2^{11}\right)$, FN824328 $\left(p v r 2^{12}\right)$, FN824330 $\left(p v r 2^{13}\right)$, FN824331 $\left(p v r 2^{14}\right)$, FN824338 $\left(p v r 2^{19}\right)$, FN824333 $\left.\left(p v r 2^{21}\right)\right]$. The codes of the accessions that were not tested in our survey, but which were used in alignment are: Genbank [AAV88614 $\left(p v r 2^{3}\right), \operatorname{AAV} 88615\left(p v r 2^{4}\right), \operatorname{AAV} 88616\left(p v r 2^{5}\right), \operatorname{AAV} 88617\left(p v r 2^{6}\right), \operatorname{ABU} 97503$ $\left(p v r 2^{7}\right), \operatorname{ABU} 97504\left(p v r 2^{8}\right), \operatorname{ABU} 97505\left(p v r 2^{9}\right), \operatorname{AAV} 88612\left(\right.$ pot- $\left.1^{+}\right)$, AAV88613 (pot1)]. 


\section{Results}

\section{Response to mechanical inoculation with TEV-7DA}

Thirty-five accessions of the genus Capsicum were mechanically inoculated with the pTEV-7DA infectious clone to evaluate their susceptibility to Tobacco etch virus. All plants of the susceptible controls, Negral and Agridulce, were infected. In Agridulce, the mean absorbances were similar to those in Negral, and maximum absorbances in these cultivars were higher than 1.30 (Table 1). Mock and negative controls were not DAS-ELISA-positive at any stage.

The virus was detected in all infected plants, showing that TEV completed the viral cycle in all of the different species analysed. All accessions, except CDP07700 and CDP06188, showed positive mean absorbances at 15 DPI and performed similarly to the susceptible controls with respect to the percentages of systemically infected plants, which was $100 \%$ throughout the survey (Online Resource 1). Nevertheless, CDP07700 of $C$. chinense and CDP06188 of C. annuum did not display $100 \%$ infected plants until 45 DPI. In CDP09688, the percentage decreased progressively from $100 \%$ at 15 DPI to $0 \%$ at $60 \mathrm{DPI}$.

In order to evaluate the response of the plants infected with Tobacco etch virus, disease symptoms were scored at 7, 15, 30, 45 and 60 DPI (Table 1). Susceptible controls developed vein clearing, leaf deformation and foliar mottling. These symptoms were followed by vein banding and stunted growth, which was detected later. These lesions were used to score the TEV symptoms from 0 for symptomless plants to 4 for plants with severe symptoms. The symptom score in Agridulce was similar to Negral, with a maximum close to 3.5 . 
Most of the accessions showed a clearly susceptible response to TEV according to the symptom rating scale. TEV-7DA induced symptoms in the five accessions of $C$. frutescens, six accessions of $C$. annuum, two of $C$. chinense, eight of $C$. baccatum and the single accessions of $C$. chacoense and $C$. pubescens. These accessions displayed maximum symptom indexes that fluctuated between strong (2.9) and severe (4). The CDP09688 accession of $C$. апnиum, which showed a decrease in viral accumulation, developed strong symptoms at 15 DPI, but at 30 DPI displayed a drastic reduction of systemic symptoms that disappeared at $60 \mathrm{DPI}$.

The C. baccatum accessions, CDP04291, CDP02320 and CDP09967, showed lower maximum symptoms than susceptible accessions, between slight (1) and moderate (1.9). Another C. baccatum accession, CDP09334, displayed very slight symptoms (0.4), which remained constant throughout the survey. CDP02521, CDP08407 and CDP07700 of $C$. chinense also developed very slight symptoms, as small mosaic dots were identified on some leaves at the end of the survey. No systemic symptoms were identified in three accessions of $C$. baccatum (CDP04865, CDP07490, CDP04131) nor in one of C. annuum (CDP06188).

Seven days after first inoculation, vein clearing started appearing on inoculated and apical leaves of many accessions (data not shown). No vein clearing was observed in seven accessions of C. baccatum (CDP04291, CDP02320, CDP09967, CDP09334, CDP04865, CDP07490, CDP04131), three of C. chinense (CDP02521, CDP08407, CDP07700) nor in one of $C$. annuum (CDP06188). This observation confirms the different responses of these accessions, which did not show symptoms during the survey, or if they did, showed only slight or moderate symptoms. 


\section{Evaluation of the TEV symptoms on fruit}

One plant from each of six susceptible accessions, all plants from symptomless accessions or those with slight or moderate symptoms, CDP09688 plants that showed an apparent recovery, ten plants from susceptible controls and the mock and negative control of each selected accession were transferred to new pots to check their TEVsymptom evolution.

TEV-7DA symptoms were observed on fruit in all susceptible accessions (Table 2). A discoloration that disappeared at red ripe stage was identified on these fruits, but the fruits were misshapen and stunted. The CDP09688 accession showed strong symptoms on leaves and fruits throughout the survey. Viral accumulation was only quantified in this accession to confirm that these symptoms were due to pTEV-7DA (data not shown). The accessions CDP06188, CDP04865, CDP07490 and CDP04131 did not display symptoms on leaves or fruits. Under these conditions, the accessions that showed very slight symptoms in the previous survey (CDP02521, CDP08407, CDP09334, CDP07700) reduced their virus incidence on leaves and fruits showed no symptoms (Fig. 1). CDP04291 and CDP09967 plants developed slight symptoms that were not identified on fruit. The moderate symptoms in the CDP02320 accession decreased during this survey and its fruits displayed very slight symptoms (0.5). Therefore, ten accessions were completely tolerant to Tobacco etch virus and CDP02320 showed a highly promising response.

\section{Amino acid substitutions in eIF4E proteins identified in resistance alleles}

We analysed the results according to allele combinations of the eIF4E and eIF(iso)4E initiation factors (Table 1; Online Resource 2). The results showed that the eIF4E alleles are involved in TEV response. Nevertheless, no resistant combination was 
related to any $e I F($ iso $) 4 E$ allele, as occurs with other potyviruses, such as PVMV (Ruffel et al. 2006; Rubio et al. 2009) and ChiVMV (Hwang et al. 2009). Thus, a multiple alignment of eIF4E proteins from resistant lines of pepper and tomato was done. This revealed that most of the eIF4E mutations are present in two accessions with different genetic backgrounds, sometimes from different species (Table 3). For instance, the A73D mutation is in $C$. chinense $\left(p v r 2^{10}\right), C$. annuum $\left(p v r 2^{5}, p v r 2^{6}, p v r 2^{9}\right)$ and $C$. baccatum $\left(p v r 2^{12}\right)$, whereas the N65D mutation is in $C$. chinense $\left(p v r 2^{11}\right)$ and $C$. baccatum $\left(p v r 2^{12}, p v r 2^{13}, p v r 2^{14}\right)$. Amino acid changes are localised in exon 1, exon 2 , exon 4 or exon 5 . The majority of the amino acid substitutions were identified in exon 1, while in exon 4, only one mutation (D205G) was identified.

Some mutations are present in TEV and PVY susceptibility alleles, such as the T51A mutation in the $p v r 2^{21}$ allele or $\mathrm{K} 71 \mathrm{R}$ in $p v r 1^{+}$. Therefore, these changes are not related to the resistance to TEV-7DA. Other amino acid changes seem to be responsible for resistance to Tobacco etch virus. The allelic variant, $p v r 2^{2}$, of the CDP06188 accession has a single amino acid substitution (D109N) which could be sufficient to limit TEV symptoms, as the other changes were also identified in TEV susceptibility alleles. Tolerant accessions with the $p v r 2^{11}, p v r 2^{12}, p v r 2^{13}$ or $p v r 2^{14}$ alleles have an amino acid substitution (N65D) that could explain their response to TEV-7DA. The change in amino acid 65 is shared with the pot- 1 allele identified in an S. habrochaites accession resistant to TEV, PI247087. The case of the tolerance alleles, $p v r 1$ and $p v r 2^{10}$, is of special note. These alleles have changes localised in exon 1 (P66T, A73D) and exon 2 (G107R) that are present separately in alleles susceptible to TEV but resistant to PVY. Thus, the presence of these amino acid changes in $p v r l$ or $p v r 2^{10}$ could explain the tolerance response of the CDP07700 and CDP02521 accessions. 


\section{Discussion}

The main objective of this study was to identify new resistance alleles against Tobacco etch virus. Although TEV is confined to the USA and the Caribbean, it has been detected in other countries and could invade new geographic areas. Thus, a screening with a pTEV-7DA infectious clone was carried out to evaluate the response of the accessions that contain different alleles of the $e I F 4 E$ and $e I F(i s o) 4 E$ genes (Ibiza et al. 2010). Accessions carrying the eIF4E alleles, $p v r 1^{+}, p v r 2^{+}, p v r 2^{1}, p v r 2^{15}, p v r 2^{16}, p v r 2^{17}$, $p v r 2^{18}, p v r 2^{19}, p v r 2^{20}, p v r 2^{21}$ or $p v r 2^{22}$, showed systemic infection and generated strong or severe symptoms. On the other hand, accessions carrying the eIF4E alleles, pvrl, $p v r 2^{2}, p v r 2^{10}, p v r 2^{11}, p v r 2^{12}, p v r 2^{13}$ or $p v r 2^{14}$, showed a tolerance response, as viral infection was detected throughout the experiment but the plants were symptomless or displayed slight or moderate symptoms on leaves.

\section{Tolerance level of the new alleles}

Several accessions included in our analysis carry eIF4E alleles that had been tested previously against TEV. When we compared previous results of the tested eIF4E alleles, the accessions that contain a susceptibility allele to Tobacco etch virus (Ruffel et al. 2002; Kang et al. 2005), $p v r 1^{+}$or $p v r 2^{+}$, displayed the expected response. These showed strong or severe symptoms. The accessions with a resistance allele, pvrl or $p v r 2^{2}$, did not inhibit viral multiplication, but no significant symptoms were identified. Nevertheless, PI159234 with the pvr1 allele and Dempsey with $p v r 2^{2}$ showed no virus accumulation when they were inoculated with the TEV-HAT and TEV-NW strains (Kang et al. 2005). Moreover, when Charron et al. (2008) inoculated two cultivars, Florida VR2 and Chay Angolano, with the $p v r 2^{2}$ allele, they also did not identify TEVHAT, however the TEV-CAA10 strain was detected on non-inoculated leaves. In our survey, $60 \%$ of the CDP07700 plants that contain the pvrl allele and $25 \%$ of the 
CDP06188 plants with the $p v r 2^{2}$ allele were DAS-ELISA-positive at 30 DPI after inoculation with the highly aphid-transmissible infectious clone, pTEV-7DA (Bedoya and Daròs 2010). In addition, all the plants of these two accessions were systemically infected at 45 DPI. In the surveys carried out by Kang et al. (2005) and Charron et al. (2008), only one mechanical inoculation was done. Therefore, our 30 days after second inoculation (30 DPI) was equivalent to 38 DPI of previous surveys in which virus accumulation was only tested on non-inoculated leaves at 21 or 30 DPI. In CDP07700 and CDP06188, the TEV-7DA VPg may have interacted with eIF4E proteins. Thus, $p v r 1$ or $p v r 2^{2}$ alleles did not block TEV-7DA replication; it was only delayed. It could also be that systemic movement of the virus was affected, as the viral protein VPg is related to cell-to-cell and long-distance movement (Schaad et al. 1997; Gao et al. 2004). Other factors may have influenced the different responses to Tobacco etch virus of these two accessions, such as the stage of development at the moment of the inoculation, inoculum pressure applied to pepper plants, environmental conditions for the plant development or the infectious clone used, as different responses were identified depending on the strain (Charron et al. 2008). Remarkably, pTEV-7DA was highly virulent as it was identified by DAS-ELISA in all accessions, $70 \%$ of which showed strong symptoms.

The three tolerant accessions with the $p v r 2^{13}$ allele had similar responses to those of CDP06188 with the $p v r 2^{2}$ allele, as no symptoms were identified on leaves. The two $C$. chinense accessions that carry the $p v r 2^{10}$ or $p v r 2^{11}$ alleles had the same reaction as did CDP07700 with the pvrl allele. These accessions developed small mosaic dots on some leaves at the end of the inoculation survey. Consequently, the tolerant accessions with the $p v r 2^{10}, p v r 2^{11}$ or $p v r 2^{13}$ alleles showed the same level of tolerance as the accessions with $p v r 1$ or $p v r 2^{2}$ when inoculated with pTEV-7DA. The $C$. baccatum accessions with 
the $p v r 2^{12}$ or $p v r 2^{14}$ alleles had a different response to previously tested alleles. These accessions showed slight or moderate symptoms during this survey.

\section{Normal development of fruits in tolerant accessions}

All plants from symptomless accessions or with slight or moderate symptoms were transferred to new pots in order to study symptom evolution at fruit state. The accessions that contain the $p v r 1, p v r 2^{2}, p v r 2^{10}, p v r 2^{11}, p v r 2^{12}, p v r 2^{13}$ or $p v r 2^{14}$ alleles were also the most tolerant based on fruit performance. The accession that displayed a drastic reduction of systemic symptoms at 45 and 60 DPI, CDP09688, showed transient apparent recovery as strong symptoms were identified during the second survey. The symptomless accessions that contain the $p v r 2^{2}$ or $p v r 2^{13}$ alleles remained without symptoms. In the accessions that carry the $p v r 2^{10}, p v r 2^{11}$ or $p v r 1$ alleles, the TEV symptoms continually decreased to 0 when the nutritive solutions were applied. It is possible that nutritional disorders, environmental conditions (light, temperature) and the physiological state of the host played an important part in symptom appearance on leaves (Bawden and Roberts 1947; Huber 1981; Liu et al. 2009). Suitable nutrition is necessary to maintain optimum plant vigour and to prevent the appearance of symptoms. In the accessions with the $p v r 2^{14}$ allele, the symptoms decreased slightly but the fruits showed no symptoms. The moderately tolerant accessions that carry the $p v r 2^{12}$ allele showed encouraging responses. The CDP04291 accession displayed a higher symptom index reduction and no symptoms were identified on fruits, whereas CDP02320 fruits showed very slight symptoms. Different factors could explain these slight symptoms, such as nutritional disorders, environmental conditions or genetic background. Therefore, the levels of tolerance of the accessions that carry the new TEV resistance alleles, $p v r 2^{10}, p v r 2^{11}, p v r 2^{12}, p v r 2^{13}$ and $p v r 2^{14}$, were highly promising. Field trials could be performed with the nine tolerant accessions to test their responses and 
study their agronomic performance against TEV strains under natural infection.

\section{Amino acid changes of eIF4E proteins responsible for tolerance to TEV}

Even through eIF4E proteins from resistant lines of pepper and tomato have changes localised in exon 1 , exon 2 , exon 4 or exon 5 , the substitutions in regions 1 or 2 are necessary to fight against viruses of the Potyvirus genus, and are clustered in two neighbouring regions of the eIF4E 3D structure located near the cap-binding pocket and at the surface of the protein (Robaglia and Caranta 2006). The eIF4E protein of the $p v r 2^{2}$ allele has a D109N change in region 2 which may be sufficient to compromise TEV infection. Nevertheless, Yeam et al. (2007) showed that this substitution is not the sole change responsible for conferring resistance to TEV-HAT, TEV-NW and TEVMex21. It seems plausible that the presence of additional mutations in region I (V67E, L79R) of the eIF4E protein of the $p v r 2^{2}$ allele could be complementary for resistance to TEV. On the other hand, Yeam et al. (2007) showed that the G107R mutation of the eIF4E protein of the $C$. chinense pvrl allelic variant is sufficient for resistance against $\mathrm{TEV}$, as it is responsible for the interruption of VPg binding in plant and in vitro. Remarkably, this change was identified in the $p v r 2^{8}$ allele, which is susceptible to TEV and resistant to PVY (Charron et al. 2008). These contradictory results could be due to the fact that A68E change, which is also identified in $p v r 2^{8}$, compensates for the G107R effect. Therefore, the tolerance of the $C$. chinense accessions with the $p v r 1$ or $p v r 2^{10}$ alleles could be due to an interaction between the G107R mutation and the others identified in region 1. Finally, the eIF4E proteins of the C. baccatum alleles, $p v r 2^{12}$, $p v r 2^{13}, p v r 2^{14}$ and $C$. chinense allele $p v r 2^{11}$, have a common amino acid substitution in exon 1 (N65D) that could compromise the TEV cycle, as it is only present in tolerance alleles. This change prevents the multiplication of PVY (Ibiza et al. 2010), and its amino acid position is shared with the pot-1 allele ( $S$. habrochaites), which confers 
resistance to TEV (Ruffel et al. 2005). To confirm this result, systematic analysis of the interactions between the eIF4E protein encoded by these new tolerance alleles and different TEV strains should be analysed.

In our survey, the changes in tolerance alleles localised in regions 1 and 2 did not block replication of TEV-7DA. Nevertheless, the amino acid changes in eIF4E proteins could be involved in the interaction with a viral protein related to its symptomatology (Urcuqui-Inchima et al. 2001), which could also interact with other plant factors. It is remarkable that VPg can interfere with the cap-binding ability of the eIF4E and eIF(iso)4E factors, interrupting the formation of the translation initiation complex (Miyoshi et al. 2006; Michon et al. 2006). The VPg protein is also not linked to the 5' end of the virus RNA; the free VPg protein appears to induce changes in the eIF4E structure diminishing its affinity to the cap structure at the 5' end host mRNAs (Grzela et al. 2006). Thus, the mutations in the eIF4E protein of tolerance alleles could produce a weaker interaction between free VPg and eukaryotic translation initiation factor 4E, which could reduce the inhibition of host protein synthesis. On the other hand, new hypotheses have been published regarding point mutations that are able to break the eIF4E-mediated recessive resistance to Lettuce mosaic virus (LMV), which infects lettuce, and to Clover yellow vein virus (ClYVV) in pea. Abdul Razzak et al. (2009) and Nakahara et al. (2010) have demonstrated that mutations in the VPg protein are not the only factor involved, as the CI protein of LMV and P1 of ClYVV are also related to the breaking of this resistance. Therefore, new surveys should be carried out in pepper to study the influence of other avirulence factors in the resistance to PVY and TEV.

\section{The use of the new tolerance alleles to TEV}

Our results confirm the identification of new resistance alleles against Tobacco etch virus: $p v r 2^{10}, p v r 2^{11}, p v r 2^{12}, p v r 2^{13}$ and $p v r 2^{14}$. The alleles identified in $C$. chinense can 
be introgressed into modern cultivars of $C$. anпиит as interspecific crosses are normally grown (Subramanya 1983; Inai et al. 1993; Costa et al. 2009). In the case of alleles detected in $C$. baccatum, the interspecific hybridisation between $C$. annuum and $C$. baccatum is not generally practical, but new targets are being achieved. In 1999, the AVRDC (Asian Vegetable Research and Development Center) reported lines that were partially compatible with a C. baccatum line (AVRDC 1999). Yoon et al. (2006) produced hybrid plants that grew vigorously but showed complete pollen sterility. The hybrid sterility was overcome through intensive backcrossing using $C$. annuиm as the pollen parent. To overcome the interspecific incompatibilities between $C$. annuum and C. baccatum, a bridge cross using $C$. chinense as the bridge parent was carried out (Yoon and Park 2005).

The combination of different resistance alleles in cultivars may provide resistance to most TEV strains. This method of plant breeding will allow the development of cultivars with a broader spectrum of resistance to the range of strains most likely to affect peppers grown in each geographic zone. It will be similar to the resistance conferred in Capsicum plants by four allelic variants at loci $L\left(L^{1}, L^{2}, L^{3}, L^{4}\right)$, which provide protection against different kinds of tobamovirus pathotypes (Boukema 1980). The new resistance alleles could help in effectively combating new strains that break the resistance. If pepper cultivars contain different resistance alleles, it will be more difficult for a new strain to break down an $e I F 4 E$ allele and infect other populations. The new strain will always be under a negative selection pressure. Moreover, these recessive alleles are more stable against the changing nature of viral pathogens than any dominant resistance genes, as the isolates to overcome the resistance must generate a new function (Flor 1971; Fraser 1992). Thus, mutations are required in the $V P g$ gene of the Tobacco etch virus to restore its interaction with the mutated eIF4E protein (Charron 
et al. 2008). The identification of these new resistance alleles to TEV and the fact that they can be in heterozygosis could make their introgression into new commercial hybrids easier.

In conclusion, we have detected five new tolerance alleles to TEV: $p v r 2^{10}, p v r 2^{11}$, $p v r 2^{12}, p v r 2^{13}$ and $p v r 2^{14}$. The tolerant accessions that carry the $p v r 2^{10}, p v r 2^{11}$ or $p v r 2^{13}$ alleles showed the same level of tolerance as the accessions with any resistance allele that had been identified previously: $p v r 1$ and $p v r 2^{2}$. The tolerance responses of the accessions that contain the $p v r 2^{12}$ or $p v r 2^{14}$ alleles were highly promising. The eIF4E proteins of the tolerance alleles have amino acid changes that are sufficient to compromise pTEV-7DA infection. The next step will be to study the isolate-specific and the resistance stability using different strains and factors. Nevertheless, new inoculations will be necessary to study the response to the range of strains most likely to affect peppers grown in each geographic zone. These results will facilitate the use of these alleles in the development of new commercial pepper cultivars and will contribute to a more effective and stable resistance to different TEV isolates.

\section{Acknowledgements}

V.P.I is the recipient of an FPU fellowship of the Ministerio de Educación y Ciencia. The authors thank J.A. Daròs for kindly providing pTEV-7DA. We also thank C. López and L. Pascual for their critical readings of the manuscript. The help of Joshua Bergen in improving the English of this manuscript is gratefully acknowledged. 


\section{References}

Abdul Razzak, A., Guiraud, T., Peypelut, M., Walter, J., Houvenaghel, M. C., Candresse, T., Le Gall, O. \& German Retana, S. (2009). Involvement of the cylindrical inclusion $(\mathrm{CI})$ protein in the overcoming of an eIF4E-mediated resistance against Lettuce mosaic potyvirus. Molecular Plant Pathology, 10, 109-113.

AVRDC (1999). Off-season tomato, pepper and eggplant. (In G. Kuo, D. Abbass, \& T. Kalb (Eds.), AVRDC 1998 Progress Report (pp. 20-30). Tainan: AVRDC).

Bawden, F. C. \& Roberts, F. M. (1947). The influence of light intensity on the susceptibility of plants to certain viruses. Annals of Applied Biology, 34, 286-296.

Bedoya, L. C. \& Daros, J. A. (2010). Stability of Tobacco etch virus infectious clones in plasmid vectors. Virus Research, 149, 234-240.

Black, L. L., Green, S. K., Hartman, G. L. \& Poulos, J. M. (1991). Pepper Diseases: A Field Guide. (In AVRDC Publication 91 (pp. 347-445). Tainan: AVRDC).

Boukema, I. W. (1980). Allelism of genes-controlling resistance to TMV in Capsicum L. Euphytica, 29, 433-439.

Browning, K. S., Webster, C., Roberts, J. K. M. \& Ravel, J. M. (1992). Identification of an Isozyme Form of Protein-Synthesis Initiation-Factor 4F in Plants. Journal of Biological Chemistry, 267, 10096-10100.

Buzkan, N., Demir, M., Öztekin, V., Mart, C., Çaglar, B. K. \& Yilmaz, M. A. (2006). Evaluation of the status of capsicum viruses in the main growing regions of Turkey. OEPP/EPPO Bulletin, 36, 15-19.

Charron, C., Nicolai, M., Gallois, J. L., Robaglia, C., Moury, B. T., Palloix, A. \& Caranta C. (2008). Natural variation and functional analyses provide evidence for coevolution between plant eIF4E and potyviral VPg. Plant Journal, 54, 56-68.

Clark, M. F. \& Adams, A. N. (1977). Characteristics of Microplate Method of Enzyme- 
Linked Immunosorbent Assay for Detection of Plant-Viruses. Journal of General Virology, 34, 475-483.

Comai, L., Young, K., Till, B. J., Reynolds, S. H., Greene, E. A., Codomo, C. A., Enns, L. C., Johnson, J. E., Burtner, C., Odden, A. R. \& Henikoff, S. (2004). Efficient discovery of DNA polymorphisms in natural populations by EcoTILLING. Plant Journal, 37, 778-786.

Costa, L. V., Lopes, R., Lopes, M. T. G., de Figueiredo, A. F., Barros, W. S. \& Alves, S. R. M. (2009). Cross compatibility of domesticated hot pepper and cultivated sweet pepper. Crop Breeding and Applied Biotechnology, 9, 37-44.

Deom, C. M., Murphy, J. F. \& Paguio, O. R. (1997). Resistance to Tobacco etch virus in Capsicum annuum: inhibition of virus RNA accumulation. Molecular PlantMicrobe Interactions, 10, 917-921.

Flor, H. H. (1971). Current status of the gene-for-gene concept. Annual Review of Phytopathology, 9, 275-296.

Fraser, R. S. (1990). The genetics of resistance to plant viruses. Annual Review of Phytopathology, 28, 179-200.

Fraser, R. S. (1992). The genetics of plant-virus interactions: implications for plant breeding. Euphytica, 63, 175-185.

Gao, Z. H., Johansen, E., Eyers, S., Thomas, C. L., Noel Ellis, T. H. \& Maule, A. J. (2004). The potyvirus recessive resistance gene, $s b m l$, identifies a novel role for translation initiation factor eIF4E in cell-to-cell trafficking. Plant Journal, 40, 376385.

Ghabrial, S. A. \& Pirone, T. P. (1967). Physiology of Tobacco etch virus-induced wilt of Tabasco peppers. Virology, 31, 154-162.

Green, S. K. \& Kim, J. S. (1991). Characteristics and control of viruses infecting peppers: A literature review. (In AVRDC Technical Bulletin 18. Tainan: AVRDC). 
Grzela, R., Strokovska, L., Andrieu, J. P., Dublet, B., Zagorski, W. \& Chroboczek, J. (2006). Potyvirus terminal protein VPg, effector of host eukaryotic initiation factor eIF4E. Biochimie, 88, 887-896.

Higgins, D. G., Thompson, J. D. \& Gibson, T. J. (1996). Using CLUSTAL for multiple sequence alignments. Computer Methods for Macromolecular Sequence Analysis, $266,383-402$.

Huber, D. M. (1981). The role of mineral nutrition in defense. (In J. G. Horsfall, \& E. B Cowling (Eds.), Plant disease and advanced treatise (pp. 386-406). New York: Academic Press).

Hwang, J., Li, J., Liu, W. Y., An, S. J., Cho, H., Her, N., Yeam, I., Kim, D. \& Kang, B. C. (2009). Double mutations in eIF4E and eIFiso4E confer recessive resistance to Chilli veinal mottle virus in pepper. Molecules and Cells, 27, 329-336.

Ibiza, V. P., Cañizares, J. \& Nuez, F. (2010). EcoTILliNG in Capsicum species: searching for new virus resistances. BMC Genomics, 11, 631 .

Inai, S., Ishikawa, K., Nunomura, O. \& Ikehashi, H. (1993). Genetic-analysis of stunted growth by nuclear-cytoplasmic interaction in interspecific hybrids of Capsicum by using RAPD markers. Theoretical and Applied Genetics, 87, 416-422.

Kang, B. C., Yeam, I., Frantz, J. D., Murphy, J. F. \& Jahn, M. M. (2005). The pvr1 locus in Capsicum encodes a translation initiation factor eIF4E that interacts with Tobacco etch virus VPg. Plant Journal, 42, 392-405.

Lellis, A. D., Kasschau, K. D., Whitham, S. A. \& Carrington, J. C. (2002). Loss-ofsusceptibility mutants of Arabidopsis thaliana reveal an essential role for eIF(iso)4E during potyvirus infection. Current Biology, 12, 1046-1051.

Leonard, S., Plante, D., Wittmann, S., Daigneault, N., Fortin, M. G. \& Laliberte, J. F. (2000). Complex formation between potyvirus VPg and translation eukaryotic initiation factor 4E correlates with virus infectivity. Journal of Virology, 74, 7730- 
7737.

Liu, J. Z., Richerson, K. \& Nelson, R. S. (2009). Growth conditions for plant virus-host studies. Current Protocols in Microbiology, 16, 16A.11.

Michon, T., Estevez, Y., Walter, J., German Retana, S. \& Le Gall, O. (2006). The potyviral virus genome-linked protein VPg forms a ternary complex with the eukaryotic initiation factors eIF4E and eIF4G and reduces eIF4E affinity for a mRNA cap analogue. FEBS Journal, 273, 1312-1322.

Miyoshi, H., Suehiro, N., Tomoo, K., Muto, S., Takahashi, T., Tsukamoto, T., Ohmori, T. \& Natsuaki, T. (2006). Binding analyses for the interaction between plant virus genome-linked protein (VPg) and plant translational initiation factors. Biochimie, 88 , 329-340.

Moury, B., Palloix, A., Selassie, K. G. \& Marchoux, G. (1997). Hypersensitive resistance to Tomato spotted wilt virus in three Capsicum chinense accessions is controlled by a single gene and is overcome by virulent strains. Euphytica, 94, 45-52.

Nakahara, K. S., Shimada, R., Choi, S. H., Yamamoto, H., Shao J. \& Uyeda I. (2010). Involvement of the P1 Cistron in Overcoming eIF4E-Mediated Recessive Resistance Against Clover yellow vein virus in Pea. Molecular Plant-Microbe Interactions, 23, 1460-1469.

Nieto, C., Piron, F., Dalmais, M., Marco, C. F., Moriones, E., Gomez Guillamon, M. L., Truniger, V., Gomez, P., Garcia Mas, J., Aranda, M. A. \& Bendahmane, A. (2007). EcoTILLING for the identification of allelic variants of melon eIF4E, a factor that controls virus susceptibility. BMC Plant Biology, 7, 34-45.

Nuez, F., Gil, R. \& Costa, J. (Eds.) (1996). El cultivo de pimientos, chiles y ajies. (Madrid: Mundi-Prensa).

Parrella, G., Ruffel, S., Moretti, A., Morel, C., Palloix, A. \& Caranta, C. (2002). Recessive resistance genes against potyviruses are localized in colinear genomic 
regions of the tomato (Lycopersicon spp.) and pepper (Capsicum spp.) genomes. Theoretical and Applied Genetics, 105, 855-861.

Riechmann, J. L., Lain, S. \& Garcia, J. A. (1992). Highlights and prospects of potyvirus molecular biology. Journal of General Virology, 73, 1-16.

Robaglia, C. \& Caranta, C. (2006). Translation initiation factors: a weak link in plant RNA virus infection. Trends in Plant Science, 11, 40-45.

Rubio, M., Nicolai, M., Caranta, C. \& Palloix, A. (2009). Allele mining in the pepper gene pool provided new complementation effects between pvr2-eIF4E and pvr6eIF(iso)4E alleles for resistance to Pepper veinal mottle virus. Journal of General Virology, 90, 2808-2814.

Ruffel, S., Dussault, M. H., Palloix, A., Moury, B., Bendahmane, A., Robaglia, C. \& Caranta C. (2002). A natural recessive resistance gene against Potato virus $Y$ in pepper corresponds to the eukaryotic initiation factor 4E (eIF4E). Plant Journal, 32, 1067-1075.

Ruffel, S., Gallois, J. L., Lesage, M. L. \& Caranta, C. (2005). The recessive potyvirus resistance gene pot-1 is the tomato orthologue of the pepper pvr2-eIF4E gene. Molecular Genetics and Genomics, 274, 346-353.

Ruffel, S., Gallois, J. L., Moury, B., Robaglia, C., Palloix, A. \& Caranta, C. (2006). Simultaneous mutations in translation initiation factors elF4E and elF(iso)4E are required to prevent Pepper veinal mottle virus infection of pepper. Journal of General Virology, 87, 2089-2098.

Schaad, M. C., Lellis, A. D. \& Carrington, J. C. (1997). VPg of Tobacco Etch Potyvirus is a Host Genotype-Specific Determinant for Long-Distance Movement. Journal of Virology, 71, 8624-8631.

Schaad, M. C., Anderberg, R. J. \& Carrington, J. C. (2000). Strain-specific interaction of the Tobacco etch virus Nla protein with the translation initiation factor elF4E in 
the yeast two-hybrid system. Virology, 273, 300-306.

Subramanya, R. (1983). Transfer of genes for multiple flowers from Capsicum chinense to Capsicum annuum. Hortscience, $18,747-749$.

Truniger, V. \& Aranda, M. A. (2009). Recessive Resistance to Plant Viruses. (In K. Maramorosch, A. Shatkin, \& F. Murphy (Eds.), Advances in Virus Research (pp. 119-159). San Diego: Elsevier).

Urcuqui Inchima, S., Haenni, A. L. \& Bernardi, F. (2001). Potyvirus proteins: a wealth of functions. Virus Research, 74, 157-175.

Ward, C. W. \& Shukla, D. D. (1991). Taxonomy of potyviruses - current problems and some solutions. Intervirology, 32, 269-296.

Yeam, I., Cavatorta, J. R., Ripoll, D. R., Kang, B. C. \& Jahn, M. M. (2007). Functional dissection of naturally occurring amino acid substitutions in eIF4E that confers recessive potyvirus resistance in plants. Plant Cell, 19, 2913-2928.

Yilmaz, M. A, Davis, R. F. \& Varney, E. H. (1983). Viruses on vegetable crops along the Mediterranean coast of Turkey. Phytopathology, 73, 378-382.

Yoon, J. B. \& Park, H. G. (2005). Trispecies bridge crosses, (Capsicum annuит $\times$ C. chinense $\times$ C. baccatum, as an alternative for introgression of anthracnose resistance from C. baccatum into C. annuum. Journal of the Korean Society for Horticultural Science, 46, 5-9.

Yoon, J. B., Yang, D. C., Do, J. W. \& Park, H. G. (2006). Overcoming two postfertilization genetic barriers in interspecific hybridization between Capsicum annиит and Capsicum baccatum for introgression of anthracnose resistance. Breeding Science, 56, 31-38. 


\section{Figure legend}

Fig. 1 TEV-7DA symptom development on leaves and fruits in tolerant accessions. (A1) Mock control of susceptible cultivar Negral at 45 DPI; (A2) Negral leaf showing mosaic and vein banding at 20 DAT; (A3) Negral fruits from an infected plant and mock control $(*)$. Fruits from the susceptible plants showed deformation in red ripe stage; (B1) Mock control of CDP04131 accession at 60 DPI; (B2) CDP04131 infected plant showed no symptoms at 20 DAT; (B3) CDP04131 fruits from infected plants and mock control (*). Fruits from CDP04131 accession showed no symptoms; (C1) Small mosaic $(*)$ along one secondary vein in a leaf of CDP08407 accession at 20 DAT; (C2) CDP08407 leaves without symptoms at 40 DAT; (C3) CDP08407 fruits from infected plants and mock control (*). Fruits from CDP08407 plants showed no symptoms; (D1) Mock control of CDP09334 accession at 60 DAT; (D2) CDP09334 leaf showing slight vein banding and mosaic at 60 DAT; (D3) CDP09334 fruits from infected plants or mock control (*). Fruits from CDP09334 plants showed no symptoms.
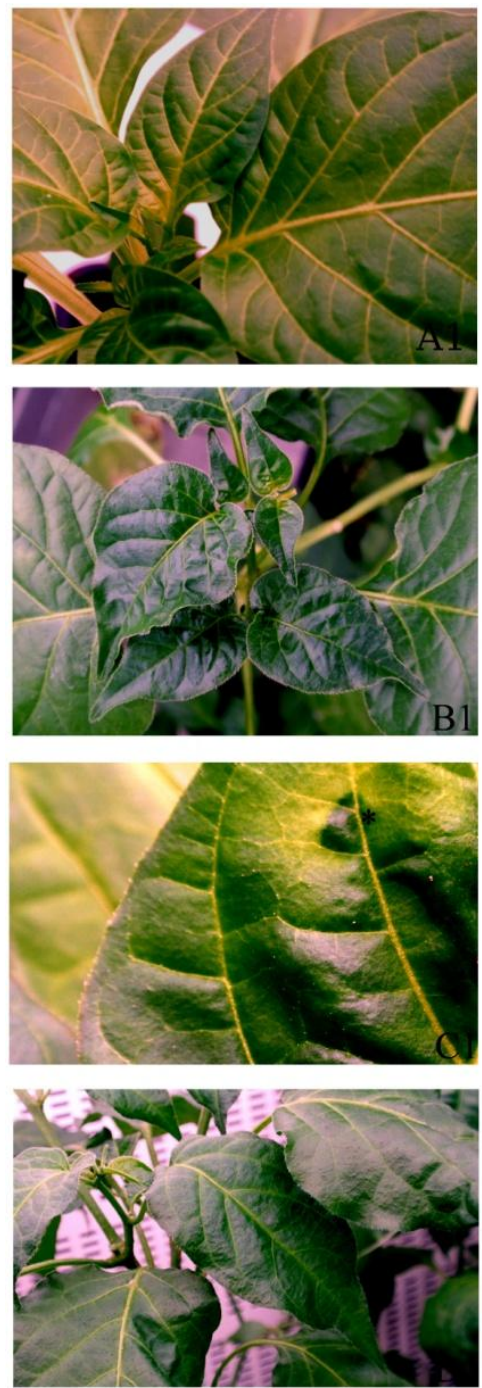
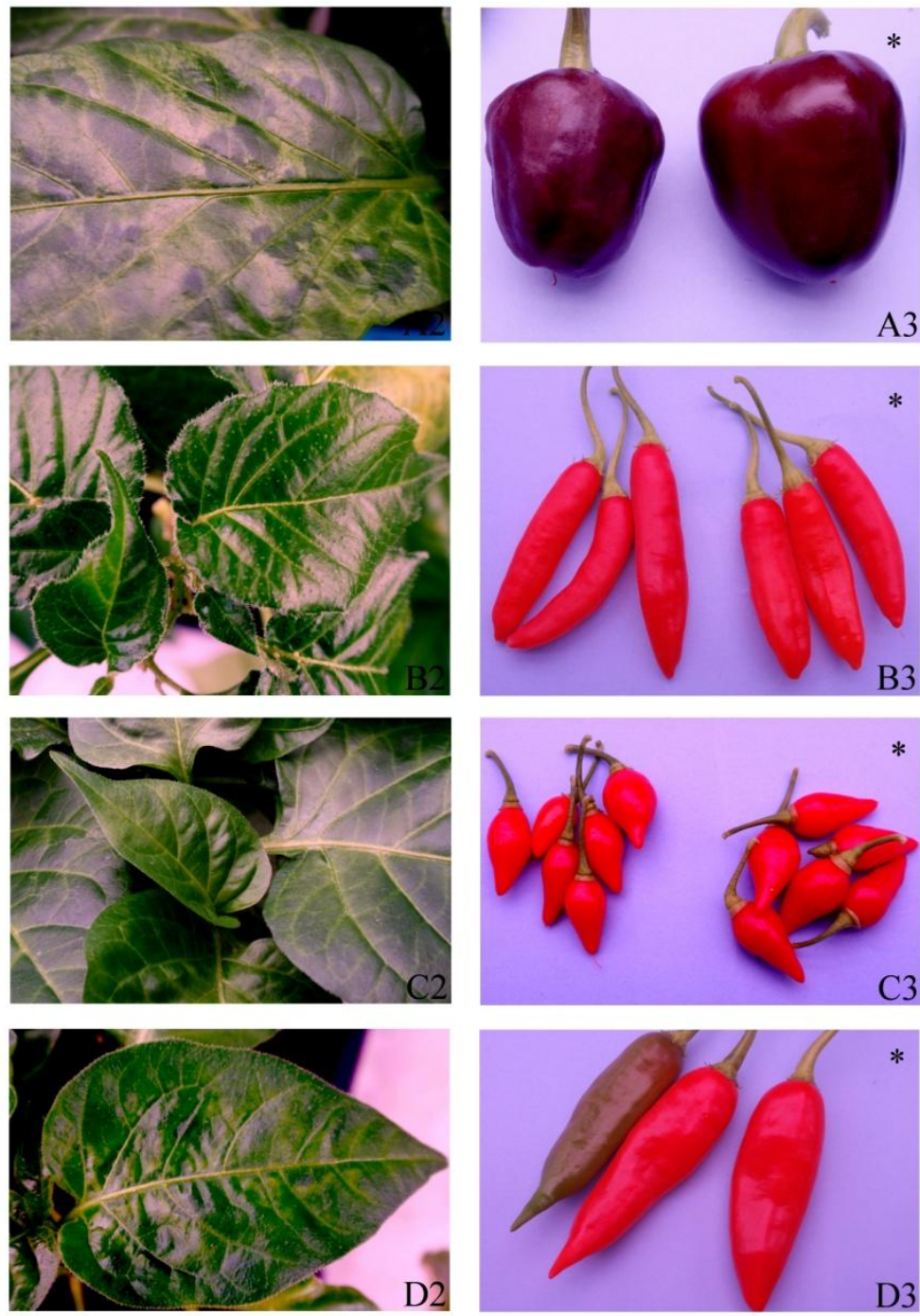
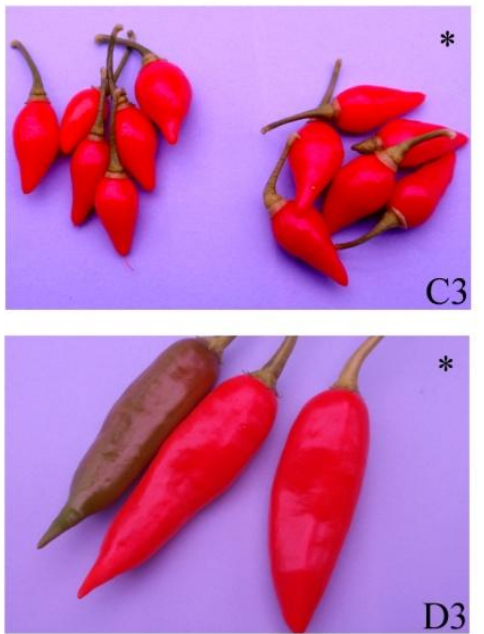


\section{Tables}

\section{Table 1 Development of TEV-7DA infection during screening and response of} accessions.

\begin{tabular}{|c|c|c|c|c|c|c|c|c|c|c|c|c|c|}
\hline \multirow[t]{2}{*}{ Accession } & \multirow[t]{2}{*}{ Species } & \multicolumn{2}{|r|}{ Allele } & \multicolumn{4}{|c|}{ Mean absorbance $\left(\mathbf{A}_{405}\right)$} & \multicolumn{5}{|c|}{ Mean foliar symptom index ${ }^{b}$} & \multirow[t]{2}{*}{ Response $^{\mathrm{c}}$} \\
\hline & & eIF4E & eIF(iso) $4 E$ & $15 \mathrm{D}^{\mathrm{a}}$ & $30 \mathrm{D}$ & $45 \mathrm{D}$ & $60 \mathrm{D}$ & $7 \mathrm{D}$ & $15 \mathrm{D}$ & $30 \mathrm{D}$ & $45 \mathrm{D}$ & $60 \mathrm{D}$ & \\
\hline CDP06188 & C. annuum & $p v r 2^{2}$ & $p v r \sigma^{+}$ & $0.03 \pm 0.01$ & $0.05 \pm 0.02$ & $0.55 \pm 0.07$ & $1.24 \pm 0.10$ & $0.0 \pm 0.00$ & $0.0 \pm 0.00$ & $0.0 \pm 0.00$ & $0.0 \pm 0.00$ & $0.0 \pm 0.00$ & $\mathrm{~T}$ \\
\hline CDP09688 & C. апnиum & $p v r 2^{+}$ & $p v r 6^{+} / p v r 6^{4}$ & $0.93 \pm 0.07$ & $1.20 \pm 0.29$ & $0.06 \pm 0.02$ & $0.03 \pm 0.00$ & $2.4 \pm 0.10$ & $3.0 \pm 0.00$ & $3.1 \pm 0.10$ & $0.4 \pm 0.10$ & $0.0 \pm 0.00$ & $\mathrm{AR}$ \\
\hline CDP02657 & C. annuиm & $p v r 2^{+}$ & $p v r 6^{+} / p v r 6^{4}$ & $0.81 \pm 0.05$ & $1.08 \pm 0.17$ & $0.12 \pm 0.01$ & $0.78 \pm 0.14$ & $3.3 \pm 0.14$ & $3.5 \pm 0.00$ & $3.0 \pm 0.20$ & $1.0 \pm 0.20$ & $1.0 \pm 0.00$ & $\mathrm{~S}$ \\
\hline CDP01263 & C. chinense & $p v r 2^{+}$ & $p v r 6^{3}$ & $1.09 \pm 0.13$ & $0.42 \pm 0.06$ & $1.62 \pm 0.13$ & $1.68 \pm 0.11$ & $1.5 \pm 0.00$ & $2.0 \pm 0.20$ & $3.0 \pm 0.00$ & $3.5 \pm 0.00$ & $3.5 \pm 0.00$ & S \\
\hline CDP04928 & C. апnиит & $p v r 2^{+}$ & $p v r 6^{+}$ & $0.90 \pm 0.08$ & $1.43 \pm 0.19$ & $0.50 \pm 0.28$ & $0.84 \pm 0.38$ & $1.5 \pm 0.00$ & $2.5 \pm 0.00$ & $3.5 \pm 0.00$ & $2.8 \pm 0.12$ & $0.8 \pm 0.30$ & $\mathrm{~S}$ \\
\hline CDP01246 & C. annuum & $p v r 2^{+}$ & $p v r 6^{4}$ & $0.85 \pm 0.05$ & $1.12 \pm 0.22$ & $0.16 \pm 0.10$ & $0.38 \pm 0.21$ & $3.0 \pm 0.00$ & $4.0 \pm 0.00$ & $4.0 \pm 0.00$ & $3.0 \pm 0.00$ & $0.5 \pm 0.00$ & $\mathrm{~S}$ \\
\hline CDP08791 & C. chacoense & $p v r 2^{15}$ & $p v r 6^{5}$ & $1.58 \pm 0.05$ & $1.67 \pm 0.05$ & $0.69 \pm 0.22$ & $1.71 \pm 0.06$ & $1.0 \pm 0.00$ & $2.5 \pm 0.00$ & $1.0 \pm 0.00$ & $2.9 \pm 0.13$ & $1.5 \pm 0.00$ & S \\
\hline CDP02521 & C. chinense & $p v r 2^{10}$ & $p v r 6^{3}$ & $0.17 \pm 0.04$ & $0.47 \pm 0.09$ & $1.60 \pm 0.09$ & $1.66 \pm 0.11$ & $0.0 \pm 0.00$ & $0.0 \pm 0.00$ & $0.0 \pm 0.00$ & $0.2 \pm 0.05$ & $0.5 \pm 0.22$ & $\mathrm{~T}$ \\
\hline CDP06433 & C. аппиит & $p v r 2^{1}$ & $p v r 6^{+}$ & $0.82 \pm 0.04$ & $1.20 \pm 0.09$ & $0.53 \pm 0.14$ & $0.97 \pm 0.35$ & $2.5 \pm 0.00$ & $3.0 \pm 0.00$ & $3.0 \pm 0.00$ & $3.0 \pm 0.00$ & $2.0 \pm 0.00$ & $\mathrm{~S}$ \\
\hline CDP01135 & C. апnиuт & $p v r 2^{1}$ & $p v r 6^{4}$ & $1.08 \pm 0.08$ & $1.29 \pm 0.10$ & $1.39 \pm 0.31$ & $1.46 \pm 0.23$ & $2.8 \pm 0.20$ & $3.4 \pm 0.10$ & $3.0 \pm 0.00$ & $3.5 \pm 0.00$ & $4.0 \pm 0.00$ & $\mathrm{~S}$ \\
\hline CDP00614 & C. baccatum & $p v r 1^{+}$ & $p v r 6^{2}$ & $0.40 \pm 0.03$ & $0.74 \pm 0.06$ & $0.60 \pm 0.25$ & $1.34 \pm 0.23$ & $1.1 \pm 0.10$ & $2.0 \pm 0.00$ & $3.0 \pm 0.16$ & $2.2 \pm 0.12$ & $1.8 \pm 0.12$ & S \\
\hline CDP05838 & C. frutescens & $p v r I^{+}$ & $p v r 6^{3}$ & $1.44 \pm 0.06$ & $1.73 \pm 0.05$ & $1.52 \pm 0.25$ & $1.58 \pm 0.14$ & $1.0 \pm 0.00$ & $1.5 \pm 0.00$ & $2.0 \pm 0.00$ & $3.0 \pm 0.00$ & $3.1 \pm 0.13$ & $\mathrm{~S}$ \\
\hline CDP07553 & C. frutescens & $p v r I^{+}$ & $p v r 6^{3}$ & $0.28 \pm 0.11$ & $1.73 \pm 0.11$ & $0.34 \pm 0.21$ & $1.37 \pm 0.06$ & $1.3 \pm 0.17$ & $2.0 \pm 0.29$ & $3.5 \pm 0.00$ & $3.5 \pm 0.29$ & $4.0 \pm 0.00$ & S \\
\hline CDP00624 & C. baccatum & $p v r l^{+}$ & $p v r 6^{+}$ & $0.76 \pm 0.05$ & $0.95 \pm 0.26$ & $0.44 \pm 0.10$ & $1.64 \pm 0.03$ & $1.5 \pm 0.00$ & $3.0 \pm 0.00$ & $3.5 \pm 0.00$ & $4.0 \pm 0.00$ & $4.0 \pm 0.00$ & S \\
\hline CDP06234 & C. baccatum & $p v r I^{+}$ & $p v r 6^{+}$ & $0.68 \pm 0.05$ & $1.13 \pm 0.10$ & $0.74 \pm 0.20$ & $1.04 \pm 0.36$ & $1.6 \pm 0.31$ & $2.8 \pm 0.14$ & $3.1 \pm 0.13$ & $3.1 \pm 0.24$ & $2.5 \pm 0.35$ & S \\
\hline CDP00620 & C. annuит & $p v r 1^{+}$ & $p v r 6^{4}$ & $1.02 \pm 0.11$ & $1.44 \pm 0.09$ & $1.39 \pm 0.33$ & $1.03 \pm 0.36$ & $1.0 \pm 0.00$ & $2.1 \pm 0.10$ & $2.9 \pm 0.10$ & $1.5 \pm 0.00$ & $0.9 \pm 0.10$ & S \\
\hline CDP05436 & C. frutescens & $p v r 2^{16}$ & $p v r 6^{3}$ & $1.21 \pm 0.13$ & $1.66 \pm 0.04$ & $1.03 \pm 0.30$ & $1.03 \pm 0.02$ & $1.5 \pm 0.00$ & $2.0 \pm 0.00$ & $3.5 \pm 0.00$ & $3.5 \pm 0.00$ & $4.0 \pm 0.00$ & S \\
\hline CDP00973 & C. frutescens & $p v r 2^{16}$ & $p v r 6^{+}$ & $1.06 \pm 0.05$ & $1.43 \pm 0.06$ & $1.22 \pm 0.27$ & $1.12 \pm 0.30$ & $1.5 \pm 0.00$ & $2.0 \pm 0.00$ & $3.5 \pm 0.00$ & $3.4 \pm 0.10$ & $3.9 \pm 0.10$ & $\mathrm{~S}$ \\
\hline CDP08407 & C. chinense & $p v r 2^{11}$ & $p v r 6^{3}$ & $0.76 \pm 0.06$ & $1.06 \pm 0.14$ & $0.57 \pm 0.26$ & $0.91 \pm 0.19$ & $0.0 \pm 0.00$ & $0.0 \pm 0.00$ & $0.0 \pm 0.00$ & $0.0 \pm 0.00$ & $0.3 \pm 0.09$ & $\mathrm{~T}$ \\
\hline CDP07700 & C. chinense & $p v r l$ & $p v r 6^{3}$ & $0.02 \pm 0.01$ & $0.50 \pm 0.21$ & $1.49 \pm 0.17$ & $1.57 \pm 0.15$ & $0.0 \pm 0.00$ & $0.0 \pm 0.00$ & $0.0 \pm 0.00$ & $0.0 \pm 0.00$ & $0.4 \pm 0.10$ & $\mathrm{~T}$ \\
\hline CDP00590 & C. pubescens & $p v r 2^{18}$ & $p v r 6^{9}$ & $1.60 \pm 0.11$ & $1.69 \pm 0.06$ & $0.98 \pm 0.38$ & $1.78 \pm 0.01$ & $1.0 \pm 0.00$ & $2.9 \pm 0.10$ & $2.5 \pm 0.00$ & $2.7 \pm 0.34$ & $1.9 \pm 0.24$ & S \\
\hline CDP04291 & C. baccatum & $p v r 2^{12}$ & $p v r 6^{2}$ & $0.77 \pm 0.25$ & $1.39 \pm 0.14$ & $0.59 \pm 0.30$ & $1.39 \pm 0.33$ & $0.4 \pm 0.29$ & $1.6 \pm 0.24$ & $1.6 \pm 0.19$ & $1.4 \pm 0.19$ & $1.0 \pm 0.16$ & MT \\
\hline CDP02320 & C. baccatum & $p v r 2^{12}$ & $p v r 6^{+}$ & $0.72 \pm 0.12$ & $1.00 \pm 0.20$ & $0.38 \pm 0.18$ & $1.72 \pm 0.03$ & $0.6 \pm 0.10$ & $1.9 \pm 0.24$ & $1.9 \pm 0.24$ & $1.9 \pm 0.37$ & $1.7 \pm 0.34$ & MT \\
\hline CDP05581 & C. baccatum & $p v r 2^{19}$ & pvr6 ${ }^{+}$ & $0.65 \pm 0.08$ & $1.14 \pm 0.08$ & $1.75 \pm 0.01$ & $0.77 \pm 0.41$ & $2.4 \pm 0.10$ & $3.1 \pm 0.10$ & $3.5 \pm 0.00$ & $4.0 \pm 0.00$ & $4.0 \pm 0.00$ & S \\
\hline CDP06360 & C. baccatum & $p v r 2^{20}$ & $p v r 6^{+}$ & $0.45 \pm 0.05$ & $0.95 \pm 0.20$ & $0.68 \pm 0.14$ & $1.20 \pm 0.17$ & $1.5 \pm 0.00$ & $2.5 \pm 0.00$ & $2.5 \pm 0.00$ & $2.0 \pm 0.00$ & $3.5 \pm 0.00$ & S \\
\hline CDP07825 & C. baccatum & $p v r 2^{20}$ & $p v r 6^{6}$ & $0.91 \pm 0.03$ & $1.50 \pm 0.13$ & $1.20 \pm 0.11$ & $1.74 \pm 0.02$ & $3.5 \pm 0.00$ & $4.0 \pm 0.00$ & $4.0 \pm 0.00$ & $4.0 \pm 0.00$ & $4.0 \pm 0.00$ & S \\
\hline CDP04865 & C. baccatum & $p v r 2^{13}$ & $p v r \sigma^{2}$ & $0.25 \pm 0.06$ & $0.48 \pm 0.04$ & $0.45 \pm 0.19$ & $0.97 \pm 0.20$ & $0.0 \pm 0.00$ & $0.0 \pm 0.00$ & $0.0 \pm 0.00$ & $0.0 \pm 0.00$ & $0.0 \pm 0.00$ & $\mathrm{~T}$ \\
\hline CDP07490 & C. baccatum & $p v r 2^{13}$ & $p v r 6^{+}$ & $0.37 \pm 0.03$ & $0.55 \pm 0.11$ & $0.13 \pm 0.03$ & $0.66 \pm 0.08$ & $0.0 \pm 0.00$ & $0.0 \pm 0.00$ & $0.0 \pm 0.00$ & $0.0 \pm 0.00$ & $0.0 \pm 0.00$ & $\mathrm{~T}$ \\
\hline CDP04131 & C. baccatum & $p v r 2^{13}$ & $p v r 6^{6}$ & $0.42 \pm 0.04$ & $0.49 \pm 0.10$ & $0.33 \pm 0.07$ & $1.19 \pm 0.33$ & $0.0 \pm 0.00$ & $0.0 \pm 0.00$ & $0.0 \pm 0.00$ & $0.0 \pm 0.00$ & $0.0 \pm 0.00$ & $\mathrm{~T}$ \\
\hline CDP09967 & C. baccatum & $p v r 2^{14}$ & $p v r \sigma^{2}$ & $1.09 \pm 0.19$ & $1.41 \pm 0.16$ & $0.62 \pm 0.22$ & $1.54 \pm 0.14$ & $0.3 \pm 0.11$ & $0.6 \pm 0.15$ & $0.9 \pm 0.20$ & $0.9 \pm 0.15$ & $1.0 \pm 0.00$ & $\mathrm{~T}$ \\
\hline CDP09334 & C. baccatum & $p v r 2^{14}$ & $p v r 6^{+}$ & $0.24 \pm 0.03$ & $0.36 \pm 0.05$ & $0.41 \pm 0.11$ & $0.87 \pm 0.24$ & $0.0 \pm 0.00$ & $0.4 \pm 0.06$ & $0.3 \pm 0.00$ & $0.4 \pm 0.06$ & $0.3 \pm 0.05$ & $\mathrm{~T}$ \\
\hline CDP01186 & C. chinense & $p v r 2^{21}$ & $p v r 6^{3}$ & $1.01 \pm 0.19$ & $1.55 \pm 0.09$ & $1.75 \pm 0.08$ & $1.79 \pm 0.02$ & $2.9 \pm 0.13$ & $3.0 \pm 0.00$ & $3.5 \pm 0.00$ & $3.4 \pm 0.13$ & $3.9 \pm 0.13$ & $\mathrm{~S}$ \\
\hline CDP05929 & C. baccatum & $p v r 2^{22}$ & $p v r 6^{2}$ & $0.43 \pm 0.07$ & $0.70 \pm 0.06$ & $0.91 \pm 0.24$ & $1.47 \pm 0.11$ & $1.0 \pm 0.00$ & $1.6 \pm 0.24$ & $2.2 \pm 0.20$ & $2.2 \pm 0.12$ & $2.9 \pm 0.37$ & S \\
\hline CDP04710 & C. baccatum & $p v r 2^{22}$ & pvr6 ${ }^{+}$ & $0.63 \pm 0.17$ & $1.03 \pm 0.14$ & $1.17 \pm 0.24$ & $0.78 \pm 0.40$ & $1.8 \pm 0.12$ & $3.0 \pm 0.00$ & $3.8 \pm 0.12$ & $4.0 \pm 0.00$ & $4.0 \pm 0.00$ & $\mathrm{~S}$ \\
\hline CDP06951 & C. frutescens & $p v r 2^{17}$ & $p v r 6^{3}$ & $1.20 \pm 0.08$ & $1.74 \pm 0.05$ & $1.36 \pm 0.19$ & $1.73 \pm 0.07$ & $1.5 \pm 0.00$ & $2.0 \pm 0.20$ & $3.0 \pm 0.20$ & $4.0 \pm 0.00$ & $4.0 \pm 0.00$ & $\mathrm{~S}$ \\
\hline Negral & C. аппиит & control & control & $0.88 \pm 0.04$ & $1.37 \pm 0.04$ & $1.35 \pm 0.19$ & $1.16 \pm 0.12$ & $1.5 \pm 0.06$ & $2.7 \pm 0.06$ & $3.4 \pm 0.04$ & $3.4 \pm 0.08$ & $2.9 \pm 0.16$ & $\mathrm{~S}$ \\
\hline Agridulce & C. апnиит & control & control & $1.02 \pm 0.11$ & $1.34 \pm 0.10$ & $0.86 \pm 0.17$ & $1.39 \pm 0.16$ & $2.5 \pm 0.10$ & $3.4 \pm 0.10$ & $3.6 \pm 0.08$ & $3.3 \pm 0.13$ & $2.6 \pm 0.30$ & S \\
\hline
\end{tabular}

${ }^{\mathrm{a}} \mathrm{D}$, Days post-inoculation. 
${ }^{\mathrm{b}}$ Range: 0 (symptomless plant), 1 (slight symptoms), 2 (moderate symptoms), 3 (strong symptoms) and 4 (severe symptoms).

${ }^{\mathrm{c}} \mathrm{T}$, Tolerant. An accession was considered tolerant when all plants were DAS-ELISA-positive without symptoms or with slight ones; MT, Moderately tolerant. All plants were DAS-ELISA-positive but symptoms were moderate; S, Susceptible. All plants were DAS-ELISA-positive and the symptom index was moderate to severe; AR, Apparent recovery. This accession showed a drastic reduction of systemic symptoms on the newly developed leaves and was DAS-ELISA-negative at 45 and 60 DPI. 
Table 2 Long-time survey to evaluate TEV-7DA symptoms in selected accessions.

\begin{tabular}{|c|c|c|c|c|c|c|c|c|c|}
\hline \multirow[b]{2}{*}{ Accession } & \multirow{2}{*}{$\begin{array}{c}\text { Number } \\
\text { of } \\
\text { infected } \\
\text { plants }\end{array}$} & \multirow{2}{*}{ Species } & \multicolumn{2}{|c|}{ Allele } & \multicolumn{4}{|c|}{ Mean foliar symptom index ${ }^{b}$} & \multirow{2}{*}{$\begin{array}{c}\text { Mean fruit } \\
\text { symptoms } \\
\text { index }^{\mathrm{b}}\end{array}$} \\
\hline & & & eIF4E & eIF(iso) $4 E$ & 20 DAT $^{\mathrm{a}}$ & 40 DAT & 60 DAT & 90 DAT & \\
\hline$\overline{\text { CDP09688 }}$ & 5 & C. anпиит & $p v r 2^{+}$ & $p v r \sigma^{+} / p v r \sigma^{4}$ & $2.5 \pm 0.16$ & $3.0 \pm 0.16$ & $3.0 \pm 0.16$ & $3.0 \pm 0.16$ & $3.0 \pm 0.16$ \\
\hline CDP04928 & 1 & C. аппиит & $p v r 2^{+}$ & $p v r 6^{+}$ & 3.5 & 3.5 & 3.5 & 4.0 & 4.0 \\
\hline CDP01263 & 1 & C. chinense & $p v r 2^{+}$ & $p v r 6^{3}$ & 3.0 & 3.0 & 3.5 & 3.5 & 3.5 \\
\hline CDP06433 & 1 & C. аппиит & $p v r 2^{1}$ & $p v r 6^{+}$ & 3.0 & 3.5 & 4.0 & 4.0 & 3.5 \\
\hline CDP06188 & 5 & C. аппиит & $p v r 2^{2}$ & $p v r 6^{+}$ & $0.0 \pm 0.00$ & $0.0 \pm 0.00$ & $0.0 \pm 0.00$ & $0.0 \pm 0.00$ & $0.0 \pm 0.00$ \\
\hline CDP02521 & 5 & C. chinense & $p v r 2^{10}$ & $p v r 6^{3}$ & $0.3 \pm 0.20$ & $0.2 \pm 0.12$ & $0.1 \pm 0.10$ & $0.0 \pm 0.00$ & $0.0 \pm 0.00$ \\
\hline CDP08407 & 5 & C. chinense & $p v r 2^{11}$ & $p v r 6^{3}$ & $0.3 \pm 0.05$ & $0.2 \pm 0.05$ & $0.2 \pm 0.06$ & $0.0 \pm 0.00$ & $0.0 \pm 0.00$ \\
\hline CDP04291 & 5 & C. baccatum & $p v r 2^{12}$ & $p v r 6^{2}$ & $0.7 \pm 0.12$ & $0.7 \pm 0.20$ & $0.6 \pm 0.10$ & $0.5 \pm 0.00$ & $0.0 \pm 0.00$ \\
\hline CDP02320 & 5 & C. baccatum & $p v r 2^{12}$ & $p v r \sigma^{+}$ & $1.7 \pm 0.34$ & $1.6 \pm 0.29$ & $1.2 \pm 0.12$ & $1.0 \pm 0.16$ & $0.5 \pm 0.16$ \\
\hline CDP04865 & 5 & C. baccatum & $p v r 2^{13}$ & $p v r 6^{2}$ & $0.0 \pm 0.00$ & $0.0 \pm 0.00$ & $0.0 \pm 0.00$ & $0.0 \pm 0.00$ & $0.0 \pm 0.00$ \\
\hline CDP07490 & 5 & C. baccatum & $p v r 2^{13}$ & $p v r \sigma^{+}$ & $0.0 \pm 0.00$ & $0.0 \pm 0.00$ & $0.0 \pm 0.00$ & $0.0 \pm 0.00$ & $0.0 \pm 0.00$ \\
\hline CDP04131 & 5 & C. baccatum & $p v r 2^{13}$ & $p v r 6^{6}$ & $0.0 \pm 0.00$ & $0.0 \pm 0.00$ & $0.0 \pm 0.00$ & $0.0 \pm 0.00$ & $0.0 \pm 0.00$ \\
\hline CDP09967 & 5 & C. baccatum & $p v r 2^{14}$ & $p v r 6^{2}$ & $0.9 \pm 0.22$ & $0.7 \pm 0.19$ & $0.6 \pm 0.09$ & $0.5 \pm 0.00$ & $0.0 \pm 0.00$ \\
\hline CDP09334 & 5 & C. baccatum & $p v r 2^{14}$ & $p v r \sigma^{+}$ & $0.3 \pm 0.09$ & $0.4 \pm 0.05$ & $0.4 \pm 0.06$ & $0.2 \pm 0.12$ & $0.0 \pm 0.00$ \\
\hline CDP05581 & 1 & C. baccatum & $p v r 2^{19}$ & $p v r \sigma^{+}$ & 4.0 & 4.0 & 4.0 & 4.0 & 3.5 \\
\hline CDP06360 & 1 & C. baccatum & $p v r 2^{20}$ & $p v r 6^{+}$ & 3.5 & 3.5 & 3.0 & 3.5 & 3.0 \\
\hline CDP04710 & 1 & C. baccatum & $p v r 2^{22}$ & $p v r 6^{+}$ & 4.0 & 4.0 & 4.0 & 4.0 & 4.0 \\
\hline CDP07700 & 5 & C. chinense & $p v r l$ & $p v r 6^{3}$ & $0.2 \pm 0.12$ & $0.1 \pm 0.06$ & $0.1 \pm 0.05$ & $0.0 \pm 0.00$ & $0.0 \pm 0.00$ \\
\hline Negral & 5 & C. аппиит & control & control & $2.5 \pm 0.16$ & $3.5 \pm 0.16$ & $3.5 \pm 0.00$ & $3.5 \pm 0.00$ & $3.5 \pm 0.00$ \\
\hline Agridulce & 5 & C. аппиит & control & control & $3.5 \pm 0.16$ & $4.0 \pm 0.00$ & $4.0 \pm 0.00$ & $4.0 \pm 0.00$ & $4.0 \pm 0.00$ \\
\hline
\end{tabular}

${ }^{\mathrm{a} D A T}$, Days after transplant.

${ }^{\mathrm{b}}$ Range: 0 (symptomless plant), 1 (slight symptoms), 2 (moderate symptoms), 3 (strong symptoms) and 4 (severe symptoms). 
Table 3 Differences in amino acid substitutions of eIF4E proteins responsible for resistance response to potyvirus in pepper and tomato.

\begin{tabular}{|c|c|c|c|c|c|c|c|c|c|c|c|c|c|c|c|c|c|c|c|c|c|}
\hline \multirow{3}{*}{$\begin{array}{l}e I F 4 E \\
\text { allele }\end{array}$} & \multirow{3}{*}{$\begin{array}{l}\text { Accession } \\
\text { or cultivar }\end{array}$} & \multirow{3}{*}{ Species } & \multirow{2}{*}{\multicolumn{2}{|c|}{$\begin{array}{l}\text { Response } \\
\text { to virus }\end{array}$}} & \multicolumn{17}{|c|}{ Exon and amino acid position ${ }^{a}$} \\
\hline & & & & & 1 & 1 & 1 & 1 & 1 & 1 & 1 & 1 & 1 & 1 & 2 & 2 & 2 & 4 & 5 & 5 & 5 \\
\hline & & & PVY & TEV & 45 & 51 & 65 & 66 & 67 & 68 & 71 & 73 & 74 & 79 & 106 & 107 & 109 & 205 & 213 & 218 & 219 \\
\hline$p v r 2^{+}$ & CDP04928 & C. аппиит & $+^{\mathrm{e}}$ & + & $\mathrm{L}$ & $\mathrm{T}$ & $\mathrm{N}$ & $P$ & $\mathrm{~V}$ & A & $\mathrm{K}$ & A & A & $\mathrm{L}$ & $\mathrm{V}$ & $\mathrm{G}$ & $\mathrm{D}$ & $\mathrm{D}$ & $\mathrm{D}$ & $\mathrm{L}$ & $\mathrm{D}$ \\
\hline$p v r 2^{21}$ & CDP01186 & C. chinense & $+^{\mathrm{e}}$ & + & - & A & - & - & - & - & $\mathrm{R}$ & - & - & - & - & - & - & - & - & - & - \\
\hline$p v r 1^{+}$ & CDP00624 & C. baccatum & $+^{\mathrm{e}}$ & + & - & - & - & - & - & - & $\mathrm{R}$ & - & - & - & - & - & - & - & - & - & - \\
\hline$p v r 2^{19}$ & CDP05581 & C. baccatum & $-\mathrm{e}$ & + & - & - & - & - & - & - & $\mathrm{R}$ & - & - & $\mathrm{R}$ & - & - & - & - & - & - & - \\
\hline pot $-1^{+}$ & PI134417 & S. habrochaites & $+^{c}$ & $+^{c}$ & - & $\mathrm{V}$ & - & S & $\mathrm{T}$ & $\mathrm{T}$ & $\mathrm{R}$ & $\mathrm{T}$ & - & - & M & - & - & - & - & - & - \\
\hline$p v r 2^{1}$ & CDP06433 & C. аппиит & $-\mathrm{e}$ & + & - & - & - & - & $\mathrm{E}$ & - & - & - & - & $\mathrm{R}$ & - & - & - & - & - & - & - \\
\hline$p v r 2^{2}$ & CDP06188 & C. аппиит & $\mathrm{-e}^{\mathrm{e}}$ & - & - & - & - & - & E & - & - & - & - & $\mathrm{R}$ & - & - & $\mathrm{N}$ & - & - & - & - \\
\hline$p v r 2^{3}$ & Perennial & C. аппиит & $-^{\mathrm{d}}$ & $t^{\mathrm{d}}$ & - & - & - & - & E & - & - & - & - & - & - & - & - & $\mathrm{G}$ & - & - & - \\
\hline$p v r 2^{4}$ & PI322719 & C. аппиит & $-{ }^{d}$ & $t^{\mathrm{d}}$ & - & - & - & - & E & - & - & - & - & - & - & - & - & - & - & - & - \\
\hline$p v r 2^{5}$ & SC81 & C. аппиит & $-{ }^{d}$ & $t^{\mathrm{d}}$ & - & - & - & $\mathrm{T}$ & E & - & - & $\mathrm{D}$ & - & - & - & - & - & - & - & - & $\mathrm{N}$ \\
\hline$p v r 2^{6}$ & Maroc1 & C. аппиит & $-{ }^{d}$ & $+^{\mathrm{d}}$ & - & - & - & - & - & $\mathrm{E}$ & - & $\mathrm{D}$ & $\mathrm{D}$ & - & - & - & - & G & - & - & - \\
\hline$p v r 2^{7}$ & Serrano V. C. & C. аппиит & $-{ }^{d}$ & $++^{\mathrm{d}}$ & - & - & - & - & $\mathrm{E}$ & - & - & - & - & $\mathrm{R}$ & - & - & - & $\mathrm{G}$ & - & - & - \\
\hline$p v r 2^{8}$ & PI195301 & C. аппиит & $-{ }^{d}$ & $t^{\mathrm{d}}$ & - & - & - & - & - & $\mathrm{E}$ & - & - & - & - & - & $\mathrm{R}$ & - & - & - & - & - \\
\hline$p v r 2^{9}$ & Chile de Arbol & C. аппиит & $-^{d}$ & $t^{\mathrm{d}}$ & - & - & - & - & - & $\mathrm{E}$ & - & $\mathrm{D}$ & - & - & - & - & - & G & - & - & - \\
\hline$p v r 1$ & CDP07700 & C. chinense & $-\mathrm{e}^{\mathrm{e}}$ & - & - & A & - & $\mathrm{T}$ & - & - & $\mathrm{R}$ & - & - & - & - & $\mathrm{R}$ & - & - & - & - & - \\
\hline$p v r 2^{10}$ & CDP02521 & C. chinense & $-\mathrm{e}$ & - & - & - & - & $\mathrm{T}$ & - & - & $\mathrm{R}$ & $\mathrm{D}$ & - & - & - & $\mathrm{R}$ & - & - & - & $\mathrm{F}$ & - \\
\hline$p v r 2^{11}$ & CDP08407 & C. chinense & $-\mathrm{e}^{\mathrm{e}}$ & - & - & - & $\mathrm{D}$ & - & - & - & $\mathrm{R}$ & - & - & - & - & - & - & - & $\mathrm{H}$ & $\mathrm{R}$ & - \\
\hline$p v r 2^{12}$ & CDP02320 & C. baccatum & $-\mathrm{e}$ & - & - & - & $\mathrm{D}$ & - & - & - & $\mathrm{R}$ & $\mathrm{D}$ & - & - & - & - & - & & - & - & - \\
\hline$p v r 2^{13}$ & CDP04131 & C. baccatum & $-\mathrm{e}$ & - & - & - & $\mathrm{D}$ & - & - & - & $\mathrm{R}$ & - & $\mathrm{D}$ & - & - & - & - & - & - & - & - \\
\hline$p v r 2^{14}$ & CDP09967 & C. baccatum & $-\mathrm{e}$ & - & - & - & $\mathrm{D}$ & - & - & - & $\mathrm{R}$ & - & - & - & - & - & - & - & - & - & - \\
\hline pot-1 & PI247087 & S. habrochaites & $-^{c}$ & $-^{c}$ & F & - & $\mathrm{K}$ & - & - & - & $\mathrm{R}$ & - & $\mathrm{D}$ & - & I & - & - & - & - & - & - \\
\hline
\end{tabular}


$p v r 2^{+}$.

b(+), Susceptible; (-), Resistant or tolerant; PVY, Potato virus Y; TEV, Tobacco etch virus.

'Data obtained from Ruffel et al. 2005 and Parrella et al. 2002 using PVY-N605 isolate and TEV-CAA10.

${ }^{\mathrm{d}}$ Data obtained from Charron et al. 2008 using PVY-LYE84 isolate and TEV-HAT.

${ }^{\mathrm{e}}$ Data obtained from Ibiza et al. 2010 using PVY-F14K isolate. 


\section{Electronic Supplementary Material}

Table 1 Percentages of DAS-ELISA-positive plants and dead plants during the mechanical inoculation survey.

File name: ESM_1.pdf

File format: pdf

Table 2 Analysis to determine what translation initiation factor is involved in TEV resistance.

File name: ESM_2.pdf

File format: pdf 

Taxonomy and genetic diversity of domesticated Capsicum species in the Andean region 

Taxonomy and genetic diversity of domesticated Capsicum species in the Andean region

Vicente P. Ibiza, José Blanca, Joaquín Cañizares and Fernando Nuez*

Instituto de Conservación y Mejora de la Agrodiversidad Valenciana (COMAV), Universidad Politécnica de Valencia, 8E CPI, Camino de Vera s/n, 46022, Valencia, Spain

*Corresponding author $(\mathrm{FN})$

E-mail address: fnuez@btc.upv.es 


\section{Abstract}

The Capsicum genus is native to tropical America and consists of 27 species, five of which are used as fresh vegetables and spices: Capsicum annuum L., Capsicum chinense J., Capsicum frutescens L., Capsicum baccatum L. and Capsicum pubescens R. \& P. The study of the relationships among species of cultivate Capsicum species will be useful for breeding new cultivars or hybrids. This study is focused on the genetic diversity and relationships of these species that were collected in the Andean region. Ten microsatellites and four AFLP combinations were used to characterize 260 Capsicum accessions. The AFLP tree turned out to be informative regarding relationships among species. The data clearly showed the close relationships between $C$. chinense and $C$. frutescens. Moreover, $C$. cardenasii and $C$. eximium were indistinguishable as a single, morphologically variable species. Our data showed $C$. baccatum and $C$. praetermissum to be distinct species that form a compact group. In the present work, AFLP fingerprinting indicated that $C$. chacoense was placed in the $C$. baccatum complex and showed $C$. tovarii as a separate species. In addition, SSR data indicated that there is intraspecific differentiation in the species $C$. chinense, $C$. baccatum and $C$. pubescens, as the PCoA-based clustering showed a clear geographic division related to country. Even though Bolivia is considered to be the nuclear area for these species, we have found similar variability in Ecuador and Peru for several Capsicum species.

Keywords Capsicum, Andean region, AFLP, SSR, phylogenetic relationships, geographic differentiation 


\section{Introduction}

The Capsicum genus is native to tropical America and consists of 27 species, five of which are used as fresh vegetables and spices: Capsicum annuum L., Capsicum chinense J., Capsicum frutescens L., Capsicum baccatum L. and Capsicum pubescens R. \& P. These species are cultivated around the world except for C. pubescens, which is only grown in the high elevation zones of the Andean region. These species are of great economic importance and are the focus of multiple breeding programs (Nuez et al. 1996).

While $C$. annuum and $C$. frutescens were domesticated in Mesoamerica, $C$. chinense, $C$. baccatum and C. pubescens were domesticated in South America (Pickersgill 2007). The greatest genetic diversity of $C$. chinense, $C$. frutescens, $C$. baccatum and $C$. pubescens is found in South America (Crosby 2008). Mexico is the primary diversity center of $C$. annuum, with secondary centers in Central America, northern South America, India, the Mediterranean region and Southeast Asia.

Three complexes have been identified in the Capsicum genus: C. annuum, C. baccatum and C. pubescens. C. annuum, C. chinense, C. frutescens, their wild relatives and Capsicum galapagoensis $\mathrm{H}$. constitute the $C$. annuum complex. These species cross with ease (Onus and Pickersgill 2004). In fact, several researchers have argued that $C$. chinense and $C$. frutescens should be considered the same species as they cross readily and are integrated into a morphological continuum (McLeod et al. 1979a; Pickersgill 1971; Walsh and Hoot 2001). C. baccatum, Capsicum praetermissum H. \& P. and Capsicum tovarii E. constitute the C. baccatum complex, but Moscone et al. (2007) indicated that the position of $C$. tovarii is not yet clear. The $C$. pubescens complex consists of $C$. pubescens, Capsicum cardenasii H. and Capsicum eximium H. Finally, 
the relationship of the wild species Capsicum chacoense $\mathrm{H}$. to these complexes is still unclear (Walsh and Hoot 2001; Tam et al. 2009).

In spite of their separation into different complexes and their apparent incompatibility, interspecific crosses have been tried in order to improve the production and quality of varieties (De Swart 2007). For instance, C. annuum and C. baccatum belong to different complexes, but several assays to obtain viable hybrids have been carried out (Yoon et al. 2006), and methods to obtain crosses between $C$. pubescens and $C$. annuum complexes have been proposed to overcome unilateral incompatibility (Pickersgill 1988; Zijlstra et al. 1991). Genes related to resistance to pepper diseases have been successfully introgressed into C. annuum from different Capsicum species (Crosby 2008).

It is necessary to develop strategies to provide information about diversity, to preserve and to use the potential of phytogenetic resources effectively in present and future breeding programs, establish conservation priorities and promote the efficient multiplication of germplasm collections. In addition, the conservation and preservation of germplasm diversity is very useful to prevent genetic erosion. The study of the diversity and relationships of Capsicum species also has agronomic relevance. $C$. chinense, $C$. frutescens, $C$. baccatum and $C$. pubescens are potential sources and have been used for C. annuum breeding related to resistance to diseases (Polston et al. 2006; Ibiza et al. 2010), pests (Fery and Thies 1997), cold tolerance (De Swart 2007) and nutritional quality (Zewdie and Bosland 2000).

Molecular techniques allow the assessment of the genetic diversity within and between species and facilitate the selection of germplasm to be used for crossing in order to achieve breeding goals and broaden the genetic basis of the current cultivars. Moreover, molecular characterization is more reliable than morphological characterization in the 
Capsicum species. Morphological characters are often difficult to evaluate as most of them are under the influence of environmental factors (Ince et al. 2010).

Molecular markers have been explored in pepper by several research groups (Rodriguez et al. 1999; Lefebvre et al. 2001). These have mainly allowed a better taxonomic assignment of accessions, the identification of duplicated accessions in germplasm banks and the analysis of the level of diversity for C. annuum (Geleta et al. 2005; Hanacek et al. 2009). In several studies, the genetic diversity of the Capsicum species was assessed in certain geographical areas, such as the Amazonas Department of Colombia or the Alta Verapaz Department of Guatemala (Toquica et al. 2003; Guzman et al. 2005). Recently, genetic relationships and diversity within and between Capsicum species have been analyzed by using RAPD or LTR-retrotransposons (Tam et al. 2009; Ince et al. 2010). Ince et al. (2010) divided Capsicum accessions by genetic analysis into the different complexes and species, and Tam et al. (2009) identified clusters of $C$. аппиит accessions that corresponded to cultivar types based on fruit shape, pungency, geographic origin and pedigree. Nevertheless, the distribution of genetic variability at the molecular level within $C$. chinense, C. frutescens, C. baccatum and C. pubescens has not been extensively studied, as all previous studies used a small number of accessions from a narrow range of distribution to represent each species. Thus, it is possible that potential intraspecific variation was inadequately sampled due to the sample sizes used in these works (Zuriaga et al. 2009a). A study with a good accession representation is therefore necessary, as the role of intraspecific variation can be especially important in studying interspecific variation and genetic relationships among species.

This study has explored the intraspecific and interspecific genetic variation of 260 accessions of $C$. annuum, $C$. chinense, $C$. frutescens, $C$. baccatum and $C$. pubescens 
throughout the Andean region in order to sample their genetic diversity. These countries, despite being the main diversification area of the studied species, received little attention in previous studies. The genetic relationships among these species are also discussed. In this study, two complementary molecular markers were chosen to study genetic relationships and variability: Amplified Fragment Length Polymorphisms (AFLPs) and Simple Sequence Repeats (SSRs). AFLPs have been proven to generate a high level of polymorphism in Solanaceae (Furini and Wunder 2004; Spooner et al. 2005; Blanca et al. 2007). Ten pepper-derived microsatellites (Minamiyama et al. 2006; Portis et al. 2007) were also used, as they are codominant, highly polymorphic and reproducible.

\section{Materials and methods}

\section{Plant materials}

In this study, 25 accessions morphologically classified as $C$. annuum, 65 as $C$. chinense, 46 as $C$. frutescens, 84 as $C$. baccatum and 40 as $C$. pubescens were used. To show the relationships of these domesticated Capsicum species to their wild relatives, 10 accessions representing five closely related wild species $(C$. cardenasii, $C$. eximium, $C$. chacoense, $C$. praetermissum and $C$. tovarii) were also included. Of these, 241 accessions were collected by the Instituto de Conservación y Mejora de la Agrodiversidad Valenciana (COMAV, Spain) with the collaboration of the Universidad Nacional de Loja (UNL, Ecuador), the Universidad Nacional de Piura (UNP, Peru), the Universidad Nacional Agraria La Molina (UNAM, Peru), the Universidad Nacional de Trujillo (UNT, Peru), the Universidad Nacional Pedro Ruiz Gallo (UNPRG, Peru) and the Universidad Mayor de San Simón (UMSS, Bolivia). The rest of the accessions were 
provided by the United States Department of Agriculture (USDA, USA), the Center for Genetic Resources (CGN, The Netherlands) and the Radboud University of Nijmegen (RUN, The Netherlands). These accessions were chosen to cover a wide range of geographical origins in Ecuador, Bolivia and Peru (Online Resource Table 1). For most included accessions, the altitude and geographic coordinates were known; the rest were approximately georeferenced using the collection site unless they were collected from food markets.

\section{Molecular marker analysis}

For each accession, genomic DNA was isolated from young leaves of one plant using the CTAB method (Doyle and Doyle 1990). To avoid the possible effect on genetic diversity estimates caused by the use of multiple close relatives, only one plant from each accession was molecularly analyzed. DNA qualities were evaluated on agarose gels, and DNA concentrations were determined spectrophotometrically using an ND1000 instrument (Thermo Fisher Scientific, Wilmington, North Carolina, USA). Finally, DNA was stored at $-20^{\circ} \mathrm{C}$ until used.

AFLPs were performed following the procedure described by Nuez et al. (2004). The restriction enzymes EcoRI and Tru9I were used for digestion, and selective amplification employed three selective nucleotides at their 3 ' ends on each primer. Four selective combinations of primers were used: EcoRI-Pet + AGG and Mse + CCG; EcoRI-Ned + ACG and Mse + CTA; EcoRI-Vic + ACC and Mse + CTA; and EcoRIFam + ACT and Mse + CTC. DNA fragments were separated in an ABI PRISM 3100 Avant Genetic Analyzer (Applied Biosystems, Woolston, UK).

All plants were screened for variation at ten polymorphic microsatellite loci (CAMS117, CAMS-122, CAMS-336, CAMS-398, CAMS-405, CAMS-606, CAMS-644, 
EPMS-725, EPMS-747 and EPMS-755) (Minamiyama et al. 2006; Portis et al. 2007). PCR reactions were performed according to the procedure reported by each of these authors and products were separated using an ABI PRISM 3100 Avant Genetic Analyzer.

\section{Genetic analysis}

The AFLP fragments of all accessions were scored for presence or absence with the Genographer software (v 2.1.4) (Benham et al. 1999) in order to build a binary matrix. A neighbor-joining tree was built with a Dice similarity matrix and branch support was assessed by using 100 bootstrapped data matrices. The allele lengths for the SSRs were determined using GeneMapper v3.7 software (Applied Biosystems, Woolston, UK). An SSR neighbor-joining tree (100 bootstrapped) was constructed with a matrix of genetic Dc distances (Cavalli-Sforza and Edwards 1967) using the Populations software v.1.2.28 (Langella 2002).

The Pearson correlation coefficient between the distance matrix of AFLPs, SSRs and geographic distances was calculated for each species using homemade Python scripts. In order to visualize the genetic relationships among the geographic regions, PCoAs (principal coordinate analyses) were built for each domesticated species. The percentage of polymorphism (P) was calculated for each analyzed species and geographic group. The subsamples were prepared taking random individuals and all of them had 10 individuals. These analyses were carried out using homemade scripts based on $\mathrm{R}$ software (v.2.6.0) (R Development Core Team 2007), available upon request. Using the Genetix software (v.4.05) (Belkhir et al. 1996), we calculated the mean (for 100 bootstrappped) of the following standard genetic parameters for each species and 
geographic group: mean number of alleles per locus (A) and observed heterozygosity (Ho).

\section{Results}

\section{Molecular characterization}

The four AFLP primer combinations produced 544 polymorphic fragments, distributed between 62 and $310 \mathrm{bp}$. A marker was considered polymorphic at the $5 \%$ level. The percentage of polymorphic bands for $C$. annuum was $37.1 \%, C$. chinense $44.7 \%, C$. frutescens $43.0 \%$, C. baccatum $42.5 \%$ and C. pubescens $46.7 \%$.

An average of 14.5 SSR alleles per locus were found in these species, ranging from 5 to 24 in the ten analyzed microsatellites. Certain alleles were specific to different geographic groups in several loci. For instance, CAMS-336 SSR showed two $C$. baccatum alleles specific to Bolivia and two $C$. chinense alleles specific to Ecuador. Other microsatellites were fixed within species, such as CAMS-398 to C. baccatum and C. pubescens and EPMS-755 to C. frutescens.

\section{Relationships among species}

An accession-based tree was created using the AFLP data. The phenogram showed nine main clusters that corresponded to the different analyzed species (Fig. 1). All accessions were neatly grouped into clusters that corresponded to their morphological classification. The AFLP data showed that $C$. chinense and $C$. frutescens are sister species, as all their accessions were in a cluster supported by a $97 \%$ bootstrap value, and a short distance was identified between the two. Inside this cluster, these two species could be discerned by high bootstrap values. $C$. annuum accessions were found in a single cluster located close to $C$. chinense and $C$. frutescens. According to this AFLP data, C. baccatum and $C$. praetermissum clustered tightly together with high 
bootstrap support (98\%). C. baccatum accessions were in a cluster supported by a 100 $\%$ bootstrap value. The results of these analyses also showed that the accessions of the wild species $C$. eximium and $C$. cardenasii were clustered together with a bootstrap value of $100 \%$. These sister species were grouped closely to C. pubescens accessions under an $85 \%$ bootstrap-supported node. Remarkably, C. chacoense and C. tovarii wild species seemed not to be related to any complex, C. chacoense is grouped with to the C. baccatum complex with a $66 \%$ bootstrap value and $C$. chacoense is with $C$. annuum complex with a $55 \%$. The species of the C. annuum complex were clearly separated from the rest of the Capsicum accessions with a bootstrap value of $72 \%$.

The dendrogram produced from the SSRs was similar to the one generated with the AFLP data (data not shown). All Capsicum accessions were perfectly grouped in different Capsicum species by SSR analysis. The main difference was the lack of good bootstrap support in the microsatellite tree.

\section{Genetic variation of domesticated species}

Several diversity indexes were calculated (Table 1), which showed that the levels of polymorphism are very similar in all domesticated Capsicum species. Overall, $C$. annuum and $C$. chinense are somewhat more variable than other Capsicum species according to the mean number of alleles per locus (A) (4.3 and 3.6, respectively). This is not the case, however, if the proportion of polymorphic loci $(\mathrm{P})$ is taken into account. In this case, $C$. pubescens is the most polymorphic species (35.3\%), but no striking differences were detected among the values. Remarkably, C. baccatum showed the highest observed heterozygosity (0.10) even through the mean number of alleles per locus was the lowest (2.4). C. chinense and C. frutescens were characterized by the lowest observed heterozygosities, 0.03 and 0.04 , respectively. 


\section{Regional differentiation and geographic group characterization}

PCoAs with SSR data were built for each domesticated species to visualize the genetic relationship among the geographic regions (Fig. 2). The C. baccatum accessions were grouped according to their geographic region of collection. The first coordinate, which accounted for $30.1 \%$ of the total variation, clearly differenced the Bolivian accessions from the Ecuadorian-Peruvian accessions. The C. pubescens accessions were also separated according to collection country. Two clear genetic clusters were differentiated, one corresponding to the Bolivian accessions and the other to the Ecuadorian-Peruvian accessions. The first two dimensions accounted for $40.4 \%$ of the C. annuиm variation, but the accessions were only slightly grouped according to their geographic region of collection, and were not separated by clear limits. No geographic cluster was identified in the $C$. frutescens accessions, perhaps because few accessions from Peru and Bolivia were analyzed. In the PCoA with all the $C$. chinense accessions, the second coordinate explained $15.0 \%$ of the variation and separated the Peruvian accessions from the rest of the accessions. No separation related to collection region was formed from the first coordinate, which accounted for $28.5 \%$ of the C. chinense variation. Various factors may have affected this result, like the relatedness between $C$. chinense and $C$. frutescens. Therefore a new PCoA was performed with all of the accessions of these sister species in order to study this relationship (data not shown). The first coordinate clearly differentiated the $C$. chinense accessions from $C$. frutescens. This PCoA confirmed the cluster analysis; C. chinense and C. frutescens accessions form two non-overlaping groups, although several accessions are located in the PCoA between both groups. To confirm this microsatellite based result, another PCoA was done with the AFLP data of $C$. chinense and C. frutescens (Online Resource Fig. 1). It 
is likely that these species of the $C$. annuиm complex cross readily as in this analysis also some accessions were also identified between both species in this new PCoA.

Moreover, in the AFLP-based tree, these accessions were grouped in the farthest nodes of each species. Similar levels of genetic differentiation among countries were also detected for $C$. chinense, $C$. baccatum and $C$. pubescens in the AFLP-based tree and PCoAs carried out with the AFLP genetic data (data not shown).

The regional differentiation showed by the PCoA analyses was also detected by a correlation analysis carried out between the genetic and geographic distances. Pearson correlation coefficients using the SSR data were only significant for $C$. baccatum $(\mathrm{r}=$ $0.44)$ and $C$. pubescens $(r=0.54)$. Nevertheless, the values calculated using the AFLP data were lower, $C$. baccatum $(\mathrm{r}=0.12)$ and $C$. pubescens $(\mathrm{r}=0.24)$.

STRUCTURE software was used to check whether the accessions of $C$. annuum, $C$. chinense, $C$. frutescens, C. baccatum and C. pubescens are differentiated by regional classification. Only a classification among countries similar to the PCoAs was found for C. chinense, C. baccatum and $C$. pubescens (data not shown). A morphological analysis with local characterization data was done with the regional differentiated accessions but not clear differential characters were identified.

The percentage of polymorphism, observed heterozygosity and mean number of alleles per locus were calculated for each geographic group of domesticated species (data not shown). The total genetic diversity was the same in the different analyzed countries for C. chinense and $C$. baccatum as no marked differences were detected. The level of polymorphism according to the proportion of polymorphic loci was approximately 36.0 $\%$ for each analyzed country for $C$. chinense and $33.5 \%$ for $C$. baccatum. No data was obtained for $C$. annuum, $C$. frutescens and $C$. pubescens because they did not have 
enough accessions per country. Another indication of the diversity are the exclusive SSR alleles which identified at least $10 \%$ of the accessions of each country. $C$. baccatum had three exclusive alleles in Bolivia that were not identified in any other countries. C. chinense had three exclusive alleles identified in Ecuador and two in Peru, while $C$. pubescens had three in Bolivia and two in Ecuador.

\section{Discussion}

To use Capsicum resources effectively, it is necessary to study the relationships among the species of Capsicum genus and to analyze plant diversity throughout its distribution. These studies are useful for the conservation of Capsicum diversity and to favor its utilization for pepper breeders as these species of Capsicum genus are a potential source for pepper breeding programs (Zewdie and Bosland 2000). The presented molecular characterization of $C$. annuum, $C$. chinense, $C$. frutescens, $C$. pubescens and $C$. baccatum has provided a complete study on the genetic relationships of these species. This study is the first to consider the genetic diversity by molecular characterization for domesticated Capsicum species from Bolivia, Ecuador and Peru, as in previous studies these countries received little attention.

\section{Relationships among species}

The genetic relationships among domesticated Capsicum species confirmed the ones previously published (Eshbaugh 1976; McLeod et al. 1982; Walsh and Hoot 2001). The data clearly showed the close relationships between $C$. chinense and $C$. frutescens. These species of the $C$. annuиm complex clustered together under a node supported by a $97 \%$ bootstrap value in the AFLP tree and showed a short distance. Although the morphological separation of these two species is difficult they form two clear 
independent clades. When PCoAs were done with SSR and AFLP data of $C$. chinense and $C$. frutescens accessions, a group of accessions common to both species was found. They might be hybrids, gene flow could be occurring as these species live together in the lower Andean land region and interspecific crosses are highly viable (Pickersgill 1971; Walsh and Hoot 2001; Guzman et al. 2005). Although $C$. chinense and $C$. frutescens were grouped together, AFLP data were sufficient to differentiate the individual members of these species under nodes supported by high bootstrap values.

In our molecular analysis, the accessions of $C$. pubescens, $C$. cardenasii and $C$. eximium were positioned in the $C$. pubescens group. The close relationships among the purpleflower species was supported by crossing experiments (Pickersgill 1991), but other studies revealed an unclear relationship among these species (Walsh and Hoot 2001; Moscone et al. 2003). In the study of Ince et al. (2010), C. eximium was placed between C. pubescens and $C$. cardenasii. C. eximium and C. cardenasii are morphological distinct, but they form natural hybrids that are more fertile than some crosses between varieties of the same species (Eshbaugh 1976; McLeod et al. 1979b). In our analysis, these two wild species were indistinguishable from each other using molecular data, as they were clustered together, as was also previously reported (Choong 1998; Ryzhova and Kochieva 2004). This result supports the definition of $C$. eximium and C. cardenasii as a single, morphologically variable species that belongs to the $C$. pubescens complex.

The accessions of $C$. baccatum and $C$. praetermissum were present in a compact group clearly segregated from the rest of the species. C. praetermissum is sometimes listed as a variety of $C$. baccatum, but our data showed it to be a distinct species (Bosland and Votava 2000) that paired tightly together (98\% bootstrap). 
In the present work, AFLP fingerprinting indicated that $C$. chacoense was placed close to $C$. baccatum, although with a low bootstrap value. Other studies resolved $C$. chacoense as the sister species to the $C$. annuum complex (Tam et al. 2009; Ince et al. 2010). According to DNA sequencing data, Walsh and Hoot (2001) reported a clear relationship between $C$. chacoense and the $C$. baccatum complex. $C$. chacoense can successfully cross with $C$. annuum and the $C$. baccatum complex (Pickersgill 1991). The results of the present analysis favor the definition of $C$. chacoense as a sister species to $C$. baccatum and within the $C$. baccatum complex.

Tong and Bosland (1999) indicated that $C$. tovarii is genetically more closely related to the $C$. baccatum complex than to the other Capsicum complexes, as successful hybridizations were obtained. Ince et al. (2010) also grouped $C$. tovarii with the $C$. baccatum clade. In contrast to this definition, the results of the present study indicate that $C$. tovarii is not a clear member of the different Capsicum complexes, though it appeared slightly closer to the $C$. annuum complex. Several studies support $C$. tovarii as being genetically different from all other species of Capsicum genus (McLeod et al. 1983; Choong 1998), while Onus and Pickersgill (2004) confirmed that C. tovarii is bilaterally compatible with all species outside the $C$. pubescens complex, showing unilateral incompatibility with these species. Moscone et al. (2007) indicated that the position of $C$. tovarii has not yet been clarified. Our results, based on a $C$. tovarii accession, showed this species to be separate from different Capsicum complexes. Thus, its position with respect to these complexes is still unclear.

The analysis of relationships among species of Capsicum genus will be useful for breeding new cultivars or hybrids for desirable traits (fruit quality, disease resistance, earliness, yield, stress tolerance and plant morphology) (Crosby 2008). In terms of pepper breeding, $C$. annuum is crossable with the other cultivated species by different 
methods (Zijlstra et al. 1991; Yoon et al. 2006). Therefore, all these species are a natural gene pool for the genetic breeding of C. annuum.

\section{Genetic variation of domesticated species}

Our molecular characterization has provided a study on the genetic diversity of domesticated Capsicum species from the Andean region. The results showed that these species have the same level of polymorphism, according to the proportion of polymorphic loci. Interestingly, $C$. pubescens showed $35.3 \%$ polymorphic loci, although DeWitt and Bosland (1996) reported that it has a narrow genetic diversity as a consequence of a founder effect during its domestication. On the other hand, $C$. baccatum has been described as a diverse species with many varietal types (DeWitt and Bosland 1996). Our results support $C$. pubescens and C. baccatum as having the same genetic diversity $C$. annuum and $C$. chinense were more variable than other Capsicum species according to the mean number of alleles per locus. This could be due to the fact that the ten polymorphic microsatellite loci used were selected for their high polymorphism in C. annuum (Minamiyama et al. 2006; Portis et al. 2007).

The heterozygosity values obtained were quite low in all species, reinforcing the idea that these domesticated species are extremely autogamous. Unlike other members of the Solanaceae family, in Capsicum genus only the wild species $C$. cardenasii is selfincompatible (Onus and Pickersgill 2004). Therefore, the low heterozygosities could be caused by the low cross-pollination rates due to the tendency toward self-pollination in Capsicum cultivated species (Eshbaugh 1976). Interestingly, C. baccatum and $C$. pubescens showed a higher Ho, although they also had low mean numbers of alleles per locus. This could suggest that these two species are more alogamous than the others. In spite of these low heterozygosities, the study of the relationships among cultivated species and their related wild species indicated that $C$. annuum, $C$. chinense, $C$. 
frutescens, C. baccatum and C. pubescens can cross with other species. This could explain why several classified accessions, such as $C$. annuum, $C$. chinense, $C$. frutescens, C. baccatum and C. pubescens, showed high genetic distances from the rest of the accessions of each species in the AFLP-based tree. Some were identified as hybrid plants between $C$. chinense and $C$. frutescens, but others could be hybrid plants with some of the studied species, with the 17 Capsicum wild species not included in this work or with their wild relatives.

\section{Regional differentiation and geographic group characterization}

The SSR data indicated that there is intraspecific differentiation in the species $C$. chinense, C. baccatum and C. pubescens, as the PCoA-based clustering showed a clear geographic division that is not related with their cultivar types. The geographic patterns of genetic differentiation in $C$. baccatum were more important than the cultivar types of the cultivated form, C. baccatum var. pendulum, which are quite diverse in size, color and shape fruit (DeWitt and Bosland 1996). The PCoA grouped, on the one hand, the Bolivian C. baccatum accessions and, on the other hand, the Peruvian-Ecuadorian accessions, whereas no cluster was identified for the accession group of var. pendulum. Bolivian accessions of $C$. pubescens were clearly differentiated from the EcuadorianPeruvian accessions. In the $C$. chinense accessions, a genetic cluster that corresponded to the Peruvian accessions was differentiated. Another indication of the geographic differentiation were the three exclusive SSR alleles found in Bolivia for C. baccatum, the three in Bolivia and the two in Ecuador for $C$. pubescens and, in the case of $C$. chinense, the three exclusive alleles identified in Ecuador and the other two in Peru. Therefore, like many other Solanaceae species, the genetic structure correlates with a geographical differentiation (Bornet et al. 2002; Zuriaga et al. 2009b; Sifres et al. 2010). Previously, Loiza-Figueroa et al. (1989) correlated genetic differentiation with 
geographic isolation in wild, semidomesticated and domesticated populations of $C$. annuum in Mexico. Unlike other crops, such as maize (Louette et al. 1997), AguilarMelendez et al. (2009) also found in Mexico that the seed exchange of semidomesticated and domesticated chilies (C. annuum) by farmers does not greatly impact genetic diversity across a broad-scale geographic range. No work has identified any geographic differentiation in other countries or Capsicum species. Capsicum fruits are used in a variety of dishes of local culinary traditions, which is diverse among regions and sometimes unique for each region of Brazil (Sudre et al. 2010). It is possible that in Bolivia, Ecuador and Peru, the use of the fruits of these species for selfconsumption is related to cultural aspects or consumer preferences that, due to continuous selection, has resulted in the genetic differentiation observed in each studied country. Moreover, the seed exchange of $C$. chinense, $C$. baccatum and $C$. pubescens does not appear to be considerable nor common among the studied countries, which should not have reduced the genetic differences. It is of note that $C$. baccatum and $C$. pubescens are cultivated in isolated mountainous regions, where access is more complicated, making seed exchange more difficult.

In the present study, the $C$. апnиum accessions were not separated geographically by clear limits. Most of the Capsicum accessions were collected from home gardens by several collection expeditions in recent decades organized by the Instituto de Conservación y Mejora de la Agrodiversidad Valenciana (COMAV). Nevertheless, most of the $C$. annuиm domesticated forms were collected from commercial crops or markets. It is possible that the use and movement of commercial cultivars from one environment to another to replace local cultivars that can be susceptible to diseases could make the grouping of $C$. annuum accessions by country difficult.

When the STRUCTURE software was used in the Capsicum accessions, in $C$. chinense, 
C. baccatum and C. pubescens a differentiation among countries was identified similar to that of the PCoAs carried out with the AFLP or SSR genetic data. It is interesting to note that the Pearson correlation coefficients calculated between molecular and geographic data showed that the SSRs allowed a better geographic classification. It is possible that microsatellites allow a better detection of recent differentiation ( $\mathrm{Li}$ et al. 2004). On the other hand, in the present study, the AFLP tree turned out to be more informative than SSR with regards to relationships among species, as it had better bootstrap support.

This study is the first to consider the genetic diversity by molecular characterization for C. annuum, C. chinense, C. frutescens, C. pubescens and C. baccatum from Bolivia, Ecuador and Peru. Bolivia is an important center of diversity for Capsicum genus, as south-central Bolivia is the nuclear area from which a migration into the Andes and lowland Amazonia was accompanied (McLeod et al. 1982). In this study, it is interesting to note that Ecuador and Peru have a high and similar diversity to Bolivia for those Capsicum species that were sufficiently represented, $C$. chinense and $C$. baccatum, although to confirm these observations more accessions should be analyzed. Ecuador and Peru are a potential gene source of traits of interest that may be employed in the use and preservation of Capsicum germplasm. Most of the accessions were collected from home gardens, which shows that they are an important option for conservation of genetic resources because of their genetic diversity (Guzman et al. 2005). It is necessary to implement strategies to gather and conserve Capsicum germplasm from South America, as it is necessary to study its characteristics, distribution and diversity. This will allow us to maximize the usefulness of genebank collections, using different techniques for plant breeding of Capsicum spp. 


\section{Acknowledgements}

VPI is the recipient of an FPU fellowship of the Ministerio de Educación y Ciencia. We want to recognize the invaluable task carried out by the Instituto de Conservación y Mejora de la Agrodiversidad Valenciana (COMAV, Spain), the Universidad Nacional de Loja (UNL, Ecuador), the Universidad Nacional de Piura (UNP, Peru), the Universidad Nacional Agraria La Molina (UNAM, Peru), the Universidad Nacional de Trujillo (UNT, Peru), the Universidad Nacional Pedro Ruiz Gallo (UNPRG, Peru), the Universidad Mayor de San Simón (UMSS, Bolivia), the United States Department of Agriculture (USDA, USA), the Center for Genetic Resources (CGN, The Netherlands) and the Radboud University of Nijmegen (RUN, The Netherlands), which provided important accessions. The help of Joshua Bergen in improving the English of this manuscript is gratefully acknowledged.

\section{References}

Aguilar-Melendez A, Peter L, Morrell, Mikeal LR, Seung Chul K (2009) Genetic diversity and structure in semiwild and domesticated chiles (Capsicum annuum; Solanaceae) from Mexico. American Journal of Botany 96:1190-1202

Belkhir K, Borsa P, Chikhi L, Rafaste N, Bonhomme T (1996) Genetix 4.04 Logiciel sours Windous TM pour la genetique des populations. Laboratoire Génome, populations, interactions, Université de Montpellier II, Montpellier. Website http://www.genetix.univ-montp2.fr/genetix/genetix.htm

Benham J, Jeung JU, Jasieniuk M, Kanazin V, Blake T (1999) Genographer: A graphical tool for automated AFLP and microsatellite analysis. Journal of Agricultural Genomics 4:3

Blanca JM, Prohens J, Anderson GJ, Zuriaga E, Canizares J, Nuez F (2007) AFLP and DNA sequence variation in an Andean domesticate, pepino (Solanum muricatum, Solanaceae): Implications for evolution and domestication. American Journal of Botany 94:1219-1229

Bornet B, Goraguer F, Joly G, Branchard M (2002) Genetic diversity in European and Argentinian cultivated potatoes (Solanum tuberosum subsp tuberosum) detected by inter-simple sequence repeats (ISSRs). Genome 45:481-484

Bosland PW, Votava EJ (2000) Peppers: Vegetable and spice capsicums. CAB International, Wallingford 
Cavalli-Sforza LL, Edwards AWF (1967) Phylogenetic analysis: models and estimation procedures. Evolution 32:550-570

Choong CY (1998) DNA polymorphisms in the study of relationships and evolution in Capsicum. PhD Thesis, University of Reading

Crosby KM (2008) Pepper. In: Prohens J, Nuez F, Carena MJ (eds) Vegetables II, 1rd edn. Springer, New York, pp 221-248

De Swart EAM (2007) Potential for breeding sweet pepper adapted to cooler growing conditions. A physiological and genetic analysis of growth traits in Capsicum. $\mathrm{PhD}$ Thesis, Wageningen University

DeWitt D, Bosland PW (1996) Peppers of the world: an identification guide. Ten Speed Press, Berkeley

Doyle JJ, Doyle JL (1990) Isolation of plant DNA from fresh tissue. Focus 12:13-15

Eshbaugh WH (1976) Genetic and biochemical systematic studies of chili peppers (Capsicum-Solanaceae). Bulletin of the Torrey Botanical Club 102:396-403

Fery RL, Thies JA (1997) Evaluation of Capsicum chinense Jacq cultigens for resistance to the southern root-knot nematode. Hortscience 32:923-926

Furini A, Wunder J (2004) Analysis of eggplant (Solanum melongena)-related germplasm: morphological and AFLP data contribute to phylogenetic interpretations and germplasm utilization. Theoretical and Applied Genetics 108:197-208

Geleta LF, Labuschagne MT, Viljoen CD (2005) Genetic variability in pepper (Capsicum annuum L.) estimated by morphological data and Amplified Fragment Length Polymorphism markers. Biodiversity and Conservation 14:2361-2375

Guzman FA, Ayala H, Azurdia C, Duque MC, de Vicente MC (2005) AFLP assessment of genetic diversity of Capsicum genetic resources in Guatemala: Home gardens as an option for conservation. Crop Science 45:363-370

Hanacek P, Vyhnanek T, Rohrer M, Cieslarova J, Stavelikova H (2009) DNA polymorphism in genetic resources of red pepper using microsatellite markers. Horticultural Science 36:127-132

Ibiza VP, Canizares J, Nuez F (2010) EcoTILLING in Capsicum species: searching for new virus resistances. BMC Genomics 11:631

Ince AG, Karaca M, Onus AN (2010) Genetic Relationships Within and Between Capsicum Species. Biochemical Genetics 48:83-95

Langella O (2002) Populations 1.2.28, Population genetic software. CNRS Website http://www.bioinformatics.org/ tryphon/populations/

Lefebvre V, Goffinet B, Chauvet JC, Caromel B, Signoret P, Brand R, Palloix A (2001) Evaluation of genetic distances between pepper inbred lines for cultivar protection purposes: comparison of AFLP, RAPD and phenotypic data. Theoretical and Applied Genetics 102:741-750

Li YC, Korol AB, Fahima T, Nevo E (2004) Microsatellites within genes: Structure, function, and evolution. Molecular Biology and Evolution 21:991-1007

Loaiza-Figueroa F, Ritland K, Laborde-Cancino JA, Tanksley SD (1989) Patterns of genetic variation of the genus Capsicum (Solanaceae) in Mexico. Plant Systematics and Evolution 165:159-188 
Louette D, Charrier A, Berthaud J (1997) In situ conservation of maize in Mexico: Genetic diversity and maize seed management in a traditional community. Economic Botany 51:20-38

McLeod MJ, Eshbaugh WH, Guttman SI (1979a) A pre-liminary biochemical systematic study of the genus Capsicum-Solanaceae. In: Hawkes JG, Lester RN, Skelding AD (eds) The Biologyand Taxonomyof the Solanaceae. Academic Press, New York, pp. 701-714

McLeod MJ, Eshbaugh WH, Guttman SI (1979b) Electrophoretic study of Capsicum (Solanaceae) - purple flowered taxa. Bulletin of the Torrey Botanical Club 106:326333

McLeod MJ, Guttman SI, Eshbaugh WH (1982) Early evolution of chili peppers (Capsicum). Economic Botany 36:361-368

McLeod MJ, Guttman SI, Eshbaugh WH, Rayle RE (1983) An electrophoretic study of evolution in Capsicum (Solanaceae). Evolution 37:562-574

Minamiyama Y, Tsuro M, Hirai M (2006) An SSR-based linkage map of Capsicum annuиm. Molecular Breeding 18:157-169

Moscone EA, Baranyi M, Ebert I, Greilhuber J, Ehrendorfer F, Hunziker AT (2003) Analysis of nuclear DNA content in Capsicum (Solanaceae) by flow cytometry and Feulgen densitometry. Annals of Botany 92:21-29

Moscone EA, Scaldaferro MA, Grabiele M, Cecchini NM, Garcia YS, Jarret R, Davina JR, Ducasse DA, Barboza GE, Ehrendorfer F (2007) The evolution of chili peppers (Capsicum - Solanaceae): a cytogenetic perspective. Proceedings of the $\mathrm{VI}^{\text {th }}$ International Solanaceae Conference. Solanaceae VI: Genomics Meets Biodiversity, pp 137-169

Nuez F, Gil R, Costa J (1996) El cultivo de pimientos, chiles y ajies. Mundi-Prensa, Madrid

Nuez F, Prohens J, Blanca JM (2004) Relationships origin, and diversity of Galapagos tomatoes: Implications for the conservation of natural populations. American Journal of Botany 91:86-99

Onus AN, Pickersgill B (2004) Unilateral incompatibility in Capsicum (Solanaceae): Occurrence and taxonomic distribution. Annals of Botany 94:289-295

Pickersgill B (1971) Relationships between weedy and cultivated forms in some species of chili peppers (genus Capsicum). Evolution 25:683-691

Pickersgill B (1988) The genus Capsicum: a multidisciplinary approach to the taxonomy of cultivated and wild plants. Biologisches Zentralblatt 107:381-389

Pickersgill B (1991) Cytogenetics and evolution of Capsicum L. In: Tsuchiya T, Gupta PK (eds) Chromosome engineering in plants: genetics, breeding, evolution. Elsevier, Amsterdam, pp 139-160

Pickersgill B (2007) Domestication of plants in the americas: Insights from mendelian and molecular genetics. Annals of Botany 100:925-940

Polston JE, Cohen L, Sherwood TA, Ben-Joseph R, Lapidot M (2006) Capsicum species: Symptomless hosts and reservoirs of Tomato yellow leaf curl virus. Phytopathology 96:447-452 
Portis E, Nagy I, Sasvari Z, Stagel A, Barchi L, Lanteri S (2007) The design of Capsicum spp. SSR assays via analysis of in silico DNA sequence, and their potential utility for genetic mapping. Plant Science 172:640-648

R Development Core Team (2007) R: A language and environment for statistical computing. R Foundation for Statistical Computing, Vienna, Austria. Website http://www.r-project.org/

Rodriguez JM, Berke T, Engle L, Nienhuis J (1999) Variation among and within Capsicum species revealed by RAPD markers. Theoretical and Applied Genetics 99:147-156

Ryzhova NN, Kochieva EZ (2004) Analysis of microsatellite loci of the chloroplast genome in the genus Capsicum (pepper). Russian Journal of Genetics 40:892-896

Sifres A, Blanca J, Nuez F (2010) Pattern of genetic variability of Solanum habrochaites in its natural area of distribution. Genetic Resources and Crop Evolution. doi: 10.1007/s10722-010-9578-0

Spooner DM, McLean K, Ramsay G, Waugh R, Bryan GJ (2005) A single domestication for potato based on multilocus amplified fragment length polymorphism genotyping. Proceedings of the National Academy of Sciences of the United States of America 102:14694-14699

Sudre CP, Goncalves LSA, Rodrigues R, do Amaral AT, Riva-Souza EM, Bento CD (2010) Genetic variability in domesticated Capsicum spp as assessed by morphological and agronomic data in mixed statistical analysis. Genetics and Molecular Research 9:283-294

Tam SM, Lefebvre V, Palloix A, Sage-Palloix AM, Mhiri C, Grandbastien MA (2009) LTR-retrotransposons Tnt1 and T135 markers reveal genetic diversity and evolutionary relationships of domesticated peppers. Theoretical and Applied Genetics 119:973-989

Tong N, Bosland PW (1999) Capsicum tovarii, a new member of the Capsicum baccatum complex. Euphytica 109:71-77

Toquica SP, Rodriguez F, Martinez E, Duque MC, Tohme J (2003) Molecular characterization by AFLPs of Capsicum germplasm from the Amazon Department in Colombia, characterization by AFLPs of Capsicum. Genetic Resources and Crop Evolution 50:639-647

Walsh BM, Hoot SB (2001) Phylogenetic relationships of Capsicum (Solanaceae) using DNA sequences from two noncoding regions: The chloroplast atpB-rbcL spacer region and nuclear waxy introns. International Journal of Plant Sciences 162:14091418

Yoon JB, Yang DC, Do JW, Park HG (2006) Overcoming two post-fertilization genetic barriers in interspecific hybridization between Capsicum annuum and Capsicum baccatum for introgression of anthracnose resistance. Breeding Science 56:31-38

Zewdie Y, Bosland PW (2000) Capsaicinoid inheritance in an interspecific hybridization of Capsicum annuum x C. chinense. Journal of the American Society for Horticultural Science 125:448-453

Zijlstra S, Purimahu AC, Lindhout P (1991) Pollen tube growth in interspecific crosses between Capsicum species. HortScience 26:585-586 
Zuriaga E, Blanca J, Nuez F (2009a) Classification and phylogenetic relationships in Solanum section Lycopersicon based on AFLP and two nuclear gene sequences. Genetic Resources and Crop Evolution 56:663-678

Zuriaga E, Blanca JM, Cordero L, Sifres A, Blas-Cerdan WG, Morales R, Nuez F (2009b) Genetic and bioclimatic variation in Solanum pimpinellifolium. Genetic Resources and Crop Evolution 56:39-51 


\section{Figure Legends}

Fig. 1 Accession-based tree built using the neighbor-joining clustering algorithm and

Dice distances calculated from AFLP data. Only bootstrap values that supported each species or complex have been printed. Numbers are the percentage of bootstrap support. Program used: Inkscape

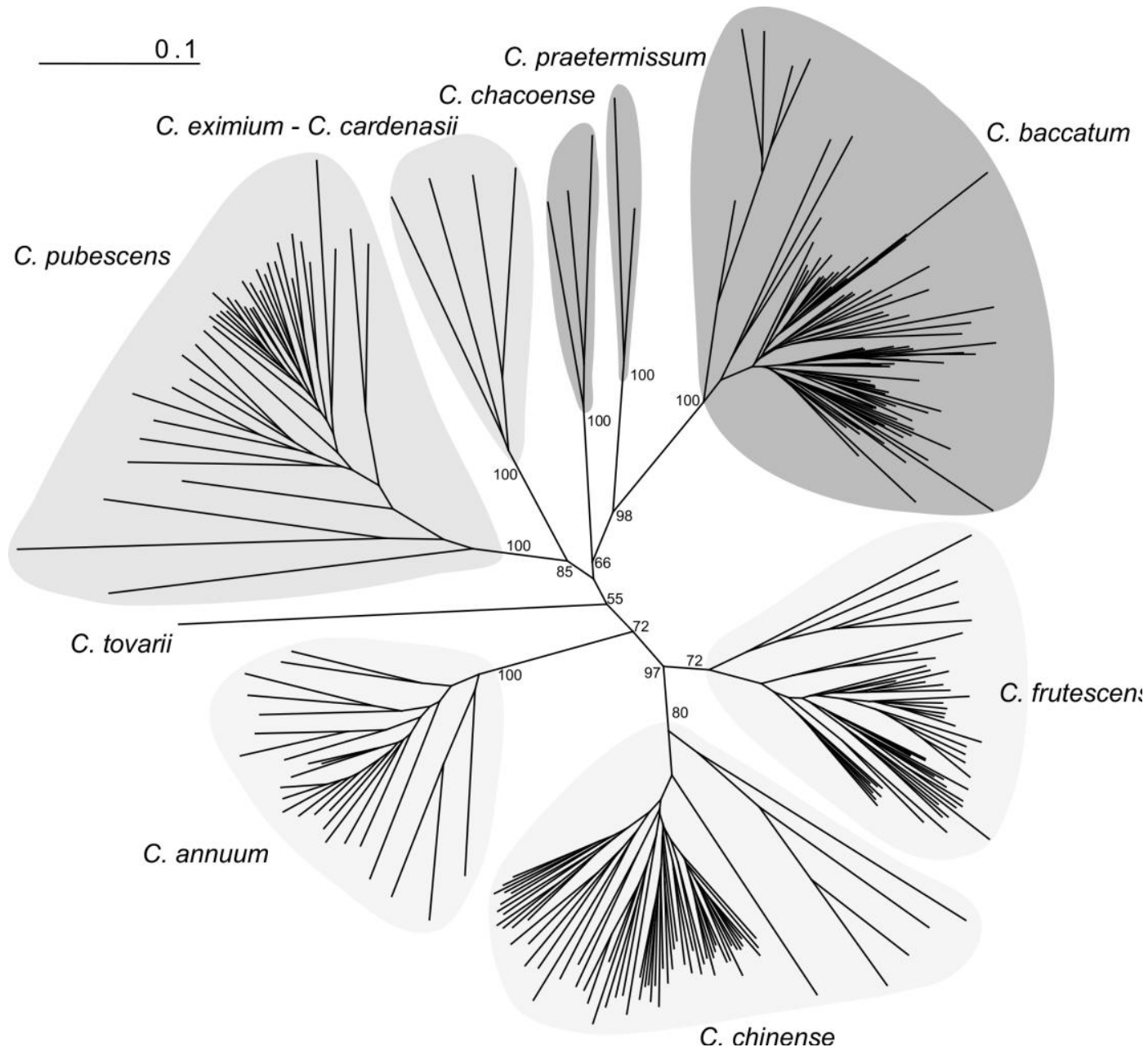


Fig. 2 PCoA analysis of the Dc distances calculated from SSR data of each studied species. (A) PCoA performed for $C$. annuum accessions with the first and second components. (B) PCoA performed for $C$. chinense accessions with the first and second components. (C) PCoA performed for $C$. frutescens accessions with the first and second components. (D) PCoA performed for C. baccatum accessions with the first and second components. (E) PCoA performed for $C$. pubescens accessions with the first and second components.

Program used: Inkscape
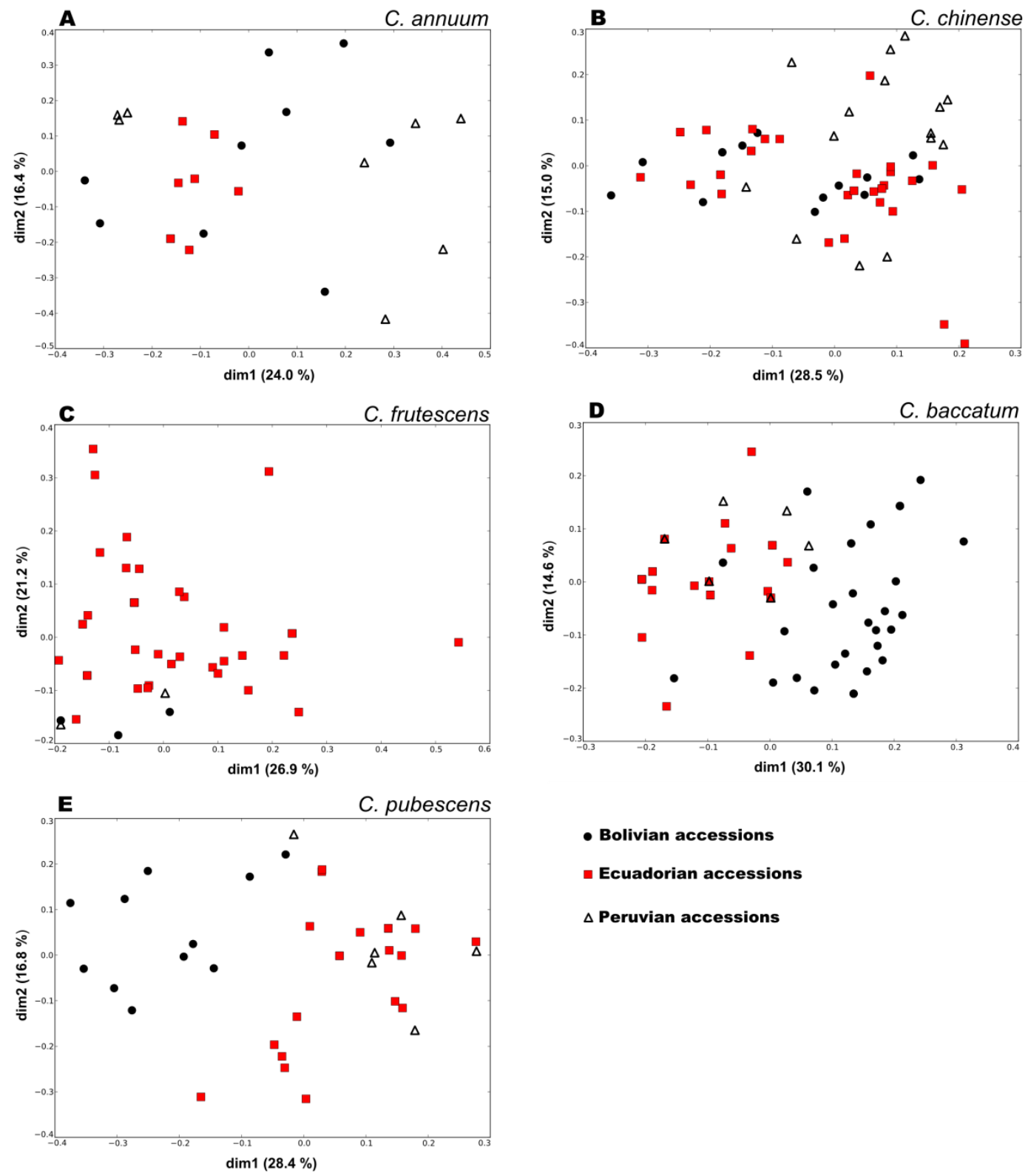
Table

Table 1 Genetic diversity found in the studied species ${ }^{\mathrm{a}}$

SSRs

AFLPs

Species n

C. anпиит

25

4.3

0.07

32.8

C. baccatum

84

2.4

0.10

32.1

C. chinense

65

3.6

0.03

32.9

C. frutescens

46

2.6

0.04

32.4

C. pubescens

40

2.9

0.08

35.3

\footnotetext{
a (n) number of individuals, (A) mean number of alleles per locus, (Ho) observed heterozygosity, (P) proportion of polymorphic loci in which the most frequent allele is under 0.95 frequency.
} 


\section{Electronic Supplementary Material}

Supplemental Fig. 1 PCoA performed with AFLP data of $C$. chinense and $C$. frutescens.

Supplemental Table 1 List of accessions used in this study, including taxonomic classification, accession identifiers, and geographic coordinates for the collection sites. 
4. DISCUSIÓN GENERAL 

Las enfermedades virales son el principal factor limitante en el cultivo del pimiento, como ocurre con otros vegetales. Por ello, la identificación de fuentes de resistencia es uno de los principales objetivos de los mejoradores. El procedimiento habitual ha sido el cribado de colecciones de germoplasma mediante fenotipado. Sin embargo ello requiere un gran esfuerzo, al ser necesario invertir grandes cantidades de trabajo y dinero durante las labores de inoculación. Esta tesis se ha centrado en la identificación más rápida y eficaz mediante la técnica EcoTILLING de nuevas variantes alélicas, relacionadas con la resistencia a virosis de distintas familias.

Por otro lado, los marcadores moleculares AFLP han permitido aportar nueva información sobre las relaciones filogenéticas de las especies más importantes del género Capsicum. Los resultados con estos marcadores han demostrado su utilidad para realizar este análisis en el género Capsicum. La variabilidad genética y su distribución en las especies domesticadas también se han analizado mediante AFLPs y SSRs. La evaluación de la diversidad genética facilita la posterior selección de germoplasma, evitando reducir la base genética de los cultivares actuales.

En los siguientes apartados del capítulo se ha tratado de profundizar en algunos aspectos discutidos por separado en cada uno de los artículos. El objetivo es ofrecer una visión general pero globalizadora de los resultados obtenidos en las distintas etapas de la investigación.

\subsection{Ventajas e inconvenientes de la identificación de mutaciones mediante el EcoTILLING basado en el ADNc}

La utilización del ADN complementario como material de partida no se había descrito previamente para la técnica EcoTILLING. La estrategia puesta a punto en esta tesis doctoral posee varias ventajas con respecto a los ensayos que utilizan directamente las secuencias de ADN (Mejlhede et al., 2006; Nieto et al., 2007; Ramos et al., 2009). La amplificación de los genes candidatos puede ser un problema en las especies silvestres o relacionadas de los cultivos. En esta situación, la disminución de la conservación de la secuencias impide la correcta unión de los cebadores o la aparición de hibridaciones inespecíficas al suavizarse las condiciones de la reacción (Nieto et al., 2007). No obstante, el uso del ADNc y cebadores localizados en las secuencias 
transcritas o codificantes, evita este conflicto al estar estas regiones más conservadas. La estrategia adoptada para evitar la identificación de las mutaciones presentes en los intrones es la de amplificar cada exón por separado (exon by exon). De esta forma para reducir el número de resultados positivos localizados en los intrones, se necesita de tantas reacciones como exones presenta el gen candidato. A diferencia, el enfoque mediante el ADNc reduce el número de reacciones PCR y CEL I por muestra. Esta tesis, es un ejemplo donde la técnica EcoTILLING basada en el ADNc resulta adecuada al analizarse diferentes especies del género Capsicum, al centrarse en las mutaciones localizadas en la secuencia exónica y, además, porque los genes contienen hasta cinco exones. Los cebadores diseñados para el gen eIF(iso) $4 E$ funcionaron perfectamente al poder amplificar este gen en todas las muestras utilizadas, únicamente en 27 entradas de distintas especies no se amplificó el gen eIF4E. Por tanto mediante el ADNc se amplificaron los genes candidatos en las distintas especies analizadas, llevándose a cabo una única reacción de PCR y CEL I por muestra. Sin embargo, uno de los aspectos a considerar con el $\mathrm{ADNc}$ es el tener que tomar las máximas precauciones para evitar la degradación del ARN total extraído de la planta. Además, es necesario realizar una reacción de transcripción reversa (RT-PCR) para poder obtener el ADNc del gen candidato. En esta reacción, la utilización de cebadores específicos mejora la eficacia y especificidad de la amplificación de los genes candidatos. Pero existe la posibilidad de utilizar oligo-dT con el fin de transcribir diferentes genes en la misma reacción RTPCR. Otro punto a considerar es la necesidad de estudiar el nivel de expresión de los genes candidatos en el tejido de la planta que se utilizará para la extracción del ARN total.

\subsection{La variabilidad del género Capsicum y su representación en la plataforma de EcoTILLING}

Diferentes entradas seleccionadas en su centro de diversidad primario $(C$. chinense, C. frutescens, C. baccatum y C. pubescens) o secundario (C. annuum) (Crosby, 2008) se han utilizado para la búsqueda de variantes alélicas de los genes eIF4E y eIF(iso)4E. En trabajos anteriores, se describieron diez variantes alélicas del gen eIF4E de C. annuum (Ruffel et al., 2002; Charron et al., 2008) y dos de C. chinense (Kang et al., 2005). Las proteínas publicadas eIF4E de C. chinense y tres de C. annuum también se identificaron en nuestra colección. En el caso del factor de iniciación a la 
traducción eIF(iso)4E, sólo se han descrito dos alelos en $C$. annuum (Ruffel et al., 2006), uno de ellos también se identificó en nuestra plataforma, $p v r 6^{+}$. Por tanto, se identificaron 16 nuevos alelos $e I F 4 E$ y otros 16 alelos $e I F($ iso $4 E$ que codifican para 14 proteínas eIF4E y 9 eIF(iso)4E. Este resultado revela la buena representación de la variabilidad del género Capsicum mediante la selección de entradas que forman la plataforma de EcoTILLING diseñada.

Respecto al polimorfismo identificado en estas variantes alélicas, 36 SNPs se detectaron en las secuencias del gen eIF4E y 26 SNPs en las secuencias del eIF(iso)4E. Previamente, el único estudio con el gen eIF4E se realizó en melón, en el cual se encontró muy baja diversidad (Nieto et al., 2007). Sólo se identificaron seis sitios polimórficos en 113 entradas de C. melo y una de Cucumis africanus L. A pesar de que nuestro ensayo se realizó únicamente a partir de la CDS (coding sequence) de los dos genes, nuestra plataforma de ADNc mostró un elevado nivel de polimorfismo en comparación con el melón, y fue similar al de otros trabajos que utilizaron otros genes y el ADN genómico como material de partida (Comai et al., 2004; Mejlhede et al., 2006; Gilchrist et al., 2006; Barkley et al., 2008; Galeano et al., 2009; Wang et al., 2007). Por otra parte, a partir de los marcadores moleculares utilizados, AFLPs y SSRs, se identificó en las especies domesticadas del género Capsicum un nivel de polimorfismo elevado y sin diferencias significativas entre ellas. Este resultado permite confirmar la buena representación de la variabilidad genética del género Capsicum en la plataforma de EcoTILLING, y explicar el porqué de la elevada cantidad de haplotipos identificados en cada una de las especies representadas. Es posible que los pimientos cultivados muestren una diversidad genética mayor en comparación con otros cultivos, como el tomate (Miller y Tanksley, 1990). También puede influir la forma de selección, que en nuestro caso, a diferencia de otros (Charron et al., 2008), está basada en el análisis intensivo de los centros de diversidad de las especies domesticadas del género Capsicum.

Estos resultados indican que nuestra plataforma de EcoTILLING es adecuada para el rastreo mediante protocolos basados en las endonucleasas. Sin embargo, esta colección será también útil en la identificación de nuevas variaciones nucleotídicas mediante otras técnicas, tal como la secuenciación directa con los nuevos sistemas de secuenciación (Next Generation Sequencing, NGS), el análisis de la curva de fusión de 
alta resolución (High Resolution Melting, HRM) o la electroforesis de capilar sensible a la conformación (Conformation sensitive capillary electrophoresis, CSCE). Recientemente se han publicado nuevos enfoques basados en estas técnicas (Dong et al., 2009; Gady et al., 2009; Rigola et al., 2009), y es muy probable que se desarrollen otras estrategias basadas en la NGS. En este escenario, nuestras plataformas de Capsicum (ADNc y $\mathrm{ADN}$ ) facilitarán la identificación de nuevas variaciones naturales en otros genes, relacionados con respuestas a factores bióticos o abióticos, o con caracteres útiles para la mejora de las especies domesticadas de pimiento.

\subsection{La diferenciación regional en las especies domesticadas del género Capsicum}

Los resultados mostraron un cierto nivel de diferenciación genética para las especies $C$. chinense, $C$. baccatum y $C$. pubescens mediante el análisis de coordenadas principales (PCoA). Previamente, se relacionó la diferenciación genética de poblaciones silvestres, semidomesticadas y domesticadas de $C$. annиит con el aislamiento geográfico en México (Loaiza-Figueroa et al., 1989; Aguilar-Meléndez et al., 2009). Sin embargo, ningún trabajo previo identificó una diferenciación geográfica en otros países y con otras especies del genero Capsicum, debido a la pobre representación del resto de las especies domesticadas y países.

Al analizar la distribución de la variabilidad genética de $C$. baccatum y $C$. pubescens en la Región Andina, la primera observación clara es el par de grupos genéticos que mostraron. Uno de ellos correspondió a las entradas procedentes de Bolivia y el otro a las entradas de Ecuador y Perú, las cuales no se separaron tan claramente. En el caso de $C$. chinense, las entradas procedentes de Perú pudieron ser diferenciadas del resto de entradas, mientras en $C$. annuиm se identificó una suave diferenciación de las entradas ecuatorianas. Al igual que en otras solanáceas, la estructura genética de las especies cultivadas de pimiento está relacionada con una diferenciación a nivel geográfico (Bornet et al., 2002; Zuriaga et al., 2009b; Sifres et al., 2010). Según nuestros resultados, el clima y la ecología no son claves para explicar las diferencias genéticas observadas, como ocurre con algunas especies silvestres de la familia Solanaceae (Zuriaga et al., 2009b; Sifres et al., 2010). Por tanto otros factores están involucrados. Los frutos de pimiento son utilizados en platos típicos de la tradición culinaria, los cuales son diferentes para cada región de Brasil (Sudre et al., 
2010). En Bolivia, Ecuador y Perú el uso de los frutos de estas especies está relacionado con aspectos culturales o preferencias de los propios consumidores. Así, como resultado de la selección continua y el aislamiento genético se habrá producido la diferenciación genética observada para cada país. Esta diferenciación parece indicar que el intercambio de semillas de $C$. chinense, $C$. baccatum y $C$. pubescens no es muy activo entre los países, al mantenerse claras diferencias genéticas entre las entradas de cada país. No obstante, ninguna subestructuración regional se identificó dentro de cada país. Al igual que ocurre con Solanum muricatum A., la diferenciación regional podría haber sido considerablemente debilitada por el intercambio humano entre las comunidades de un mismo país durante las últimas décadas (Blanca et al., 2007). Este fenómeno ha producido cambios en los mercados, donde antes se vendían únicamente cultivos caseros o locales y en los que, por una mayor facilidad en los desplazamientos, se han introducido cultivos de otras regiones (Zuriaga, 2009). Por tanto, al igual que en la judía (Papa y Gepts, 2003), el intercambio de semillas de variedades locales podría verse favorecido en un rango geográfico reducido ya que las condiciones climáticas suelen ser más similares que entre los países. Todo esto apoya la idea de que el intercambio de semillas de Capsicum es común dentro de los países analizados, pero no es elevado entre ellos. Resaltar que tanto $C$. pubescens y $C$. baccatum son cultivadas en las regiones montañosas de los países andinos estudiados (Nuez et al., 1996), donde las comunicaciones son aun más complicadas. Por tanto el intercambio de semillas es más difícil, manteniéndose las diferencias genéticas. Serían necesarios análisis más amplios para poder confirmar estos resultados.

Aunque Bolivia es un importante centro de diversidad del género Capsicum (McLeod et al., 1983), es interesante señalar que en este estudio las entradas de Ecuador y Perú han mostrado una diversidad elevada y similar a la de Bolivia. Por otra parte, se han identificado algunos haplotipos de los genes eIF4E y eIF(iso)4E únicamente en alguno de los países representados. Entre otros, los alelos $p v r 2^{13}$, $p v r 2^{22}$ o $p v r 6^{6}$ en Bolivia, mientras que $p v r 2^{16}$ en Ecuador. Este resultado verifica que las entradas procedentes de diferentes países pueden mostrar alelos que no serán identificados en otras regiones. En conclusión, tanto las entradas de Bolivia como las de Perú y Ecuador podrían ser buenas fuentes de genes para ser utilizadas en los programas de mejora del pimiento dulce (C. annuum) o de otras especies. 
Los datos de la distribución de la variabilidad servirán para establecer una colección nuclear de las entradas del género Capsicum conservadas en el COMAV, manteniéndose la máxima variabilidad de una especie en el menor número de entradas. Esta colección aumentará la eficacia del manejo de las entradas del Banco de Germoplasma del COMAV. El conocimiento de la distribución de la variabilidad permitirá desarrollar nuevas plataformas o rediseñar la plataforma de Capsicum disponible. Estas serán analizadas mediante EcoTILLING o con las nuevas metodologías de detección de mutaciones. La nueva plataforma mejorará la representación de entradas procedentes de Perú y aquellas regiones que estén menos representadas de Bolivia y Ecuador. Todo ello aumentará la variabilidad y la probabilidad de encontrar nuevos alelos.

\subsection{Las relaciones filogenéticas en el género Capsicum}

Las relaciones filogenéticas han sido objeto de discusión y controversia en los últimos años, pero no se ha alcanzado un consenso definitivo en algunas especies. Nuestros datos muestran la estrecha relación entre las especies $C$. chinense y $C$. frutescens. Esta relación altamente significativa podría deberse a la gran similitud morfológica, la cual favorece la integración de los individuos de estas especies en un continuo morfológico (Walsh y Hoot, 2001). No obstante, los dos clusters pertenecientes a las entradas de estas especies hermanas se diferenciaron con un elevado valor de bootstrap. Por tanto, estas dos especies aunque son muy cercanas pueden ser diferenciadas molecularmente. A partir de nuestro análisis molecular las entradas de $C$. pubescens, C. cardenasii y C. eximium se diferenciaron conjuntamente del resto, pero C. cardenasii y $C$. eximium fueron indistinguibles molecularmente. Este resultado apoya la definición de $C$. eximium y $C$. cardenasii como una especie única y variable morfológicamente (Choong, 1998; Ryzhova y Kochieva, 2004). En cuanto a $C$. baccatum y $C$. praetermissum, los resultados mostraron que son especies distintas que forman un grupo compacto (Bosland y Votava, 2000). En base a nuestras observaciones y a diferencia de otros estudios (Tong y Bosland, 1999; Tam et al., 2009; Ince et al., 2010), C. chacoense fue incluida en el complejo de C. baccatum (Walsh y Hoot, 2001; Pickersgill, 1991) mientras C. tovarii no perteneció a ningún complejo (McLeod et al., 1983; Choong 1998). 
Respecto a los haplotipos $e I F 4 E$ y $e I F(i s o) 4 E$, la mayoría fueron específicos de especie. Sin embargo, algunos de ellos están presentes en distintas especies. Por ejemplo, el alelo $p v r 2^{+}$está en $C$. annuum y $C$. chinense, y $p v r 2^{16}$ en $C$. chinense y $C$. frutescens. El flujo genético entre las especies del complejo de C. annuum puede explicar la presencia de alelos compartidos entre ellas (Ince et al., 2010). A la vez, la ausencia de barreras de cruzabilidad aumenta la relación existente entre las especies que forman cada uno de los complejos. De esta forma, el análisis de las relaciones entre las especies del género Capsicum será útil para la mejora de nuevas variedades o híbridos según los caracteres deseables (calidad del fruto, resistencia a enfermedades, precocidad, rendimiento, tolerancia a estreses y morfología) (Crosby, 2008). En cuanto a la mejora de $C$. annuum, esta puede cruzar con las otras especies cultivadas mediante diferentes métodos (Zijlstra et al., 1991; Yoon et al., 2006). Por tanto, todas estas especies constituyen un patrimonio genético natural para la mejora genética del pimiento.

\subsection{La funcionalidad de las nuevas variantes alélicas de los genes eIF4E y eIF(iso) $4 E$}

Los resultados iniciales de la tesis demostraron que nuestra plataforma contiene suficiente variabilidad para detectar nuevas mutaciones en los genes eIF4E y eIF(iso)4E. El siguiente objetivo fue demostrar la utilidad de las nuevas variantes alélicas. Para ello, una colección de entradas que representan las distintas combinaciones de los alelos eIF4E y $e I F(i s o) 4 E$ se inocularon mecánicamente con el Potato virus $Y$ (PVY) y el Tobacco etch virus (TEV). El fin fue conocer que alelos confieren resistencia frente a dos virus muy destructivos del pimiento (Black et al., 1991; Jordá, 2006).

A partir del análisis de la correlación entre las proteínas eIF4E y eIF(iso)4E y la respuesta de las entradas frente a los virus, se observó que las proteínas eIF(iso)4E no estuvieron involucradas ni en la resistencia al PVY ni en la tolerancia al TEV. La respuesta de cada una de las entradas se explicó a partir de las proteínas eIF4E. Según nuestros resultados cinco nuevas variantes del gen eIF4E $\left(p v r 2^{10}, p v r 2^{11}, p v r 2^{12}, p v r 2^{13}\right.$ $\mathrm{y} p v r 2^{14}$ ) estuvieron relacionadas con la respuesta de resistencia al Tobacco etch virus $\mathrm{y}$ al Potato virus Y. Este resultado reveló la elevada utilidad de esta plataforma en la 
búsqueda de nuevos alelos de gran utilidad en la mejora del pimiento. Destacar que los alelos de resistencia publicados (Kang et al., 2005; Charron et al., 2008) y los nuevos alelos de resistencia identificados están presentes en entradas que proceden de los tres países andinos estudiados. Esto demuestra la importancia de utilizar los recursos fitogenéticos disponibles del género Capsicum para la mejora del pimiento.

Los alelos de resistencia del gen eIF4E poseen diferentes combinaciones de cambios aminoacídicos, localizados en las regiones I (exón 1) y II (exón 2) de la proteína eIF4E (Charron et al., 2008; Robaglia y Caranta, 2006). Como consecuencia, los cambios en estas regiones parecen responsables de la resistencia, al menos contra el PVY y el TEV (Ruffel et al., 2002; Kang et al., 2005; Yeam et al., 2007; Charron et al., 2008). Los nuevos alelos de resistencia $p v r 2^{12}, p v r 2^{13}$ y $p v r 2^{14}$ de C. baccatum y $p v r 2^{11}$ de $C$. chinense codifican un aminoácido en el exón 1 (N65D), el cual puede evitar la multiplicación del PVY. Por otra parte, la proteína eIF4E del alelo resistente $p v r 2^{10}(C$. chinense) tiene otros cambios de aminoácidos situados en las regiones I y II. La combinación de estas mutaciones podría explicar la respuesta resistente al PVY. Sin embargo, estos cambios no bloquearon la replicación del aislado TEV-7DA pero fueron suficientes para comprometer su infección. Las entradas que contienen estos alelos mostraron una respuesta tolerante a este aislado.

La resistencia a las nuevas cepas del TEV y PVY será más eficaz con los nuevos alelos. Si en una misma región de cultivo cada uno de los diferentes cultivares estuvieran fijados para distintos alelos, sería más difícil que una cepa rompiera la resistencia conferida por un alelo eIF4E e infectará rápidamente las otras poblaciones. La cepa estaría bajo una presión de selección negativa que limitaría o bloquearía su expansión. Estos cultivares tendrían un espectro de resistencia más amplio frente aquellas cepas que se encuentren en mayor probabilidad en cada zona geográfica. Este método de lucha contra las virosis es similar a la resistencia conferida en cultivares de pimiento por las cuatro variantes alélicas del loci $\mathrm{L}\left(L^{1}, L^{2}, L^{3}, L^{4}\right)$. Estas proporcionan una protección efectiva contra diferentes tobamovirus (Boukema, 1980). Futuros estudios podrán posibilitar el uso en heterocigosis de estos cinco nuevos alelos resistentes del gen $e I F 4 E$; facilitándose su introgresión en nuevos híbridos comerciales. Adicionalmente, estos alelos al ser recesivos son una excelente reserva contra la naturaleza cambiante de los patógenos virales estudiados. Es decir, serán necesarias 
mutaciones en el gen $V P g$ del PVY y TEV para restaurar su interacción con las proteínas mutadas eIF4E (Charron et al., 2008; Moury et al., 2004). Por tanto la durabilidad de la resistencia será mayor que en el caso de utilizar una resistencia conferida por un gen R (Fraser, 1990, 1992).

\subsection{Las perspectivas del futuro}

Los datos obtenidos han validado la estrategia de EcoTILLING basada en el ADNc y la colección de entradas del género Capsicum del COMAV para la búsqueda de nuevos alelos de resistencia. En el futuro, el desarrollo de nuevas tecnologías y la incorporación de los resultados de variabilidad a la plataforma aumentarán las oportunidades de identificar nuevos alelos. Sin dejar de lado C. annuum, C. frutescens y $C$. pubescens, las especies $C$. chinense y $C$. baccatum incrementarán su participación en la futura plataforma, al mostrar una elevada variabilidad y al pertenecer los nuevos alelos de resistencia detectados a estas dos especies. Por otro lado, las entradas de $C$. chinense, C. baccatum y $C$. pubescens mostraron una clara estructuración genética relacionada geográficamente. Así, las entradas de Bolivia, Ecuador y Perú constituyen diferentes fuentes de genes. Por tanto, los resultados obtenidos a partir de la caracterización fenotípica y del estudio de la variabilidad mejorarán aún más la plataforma para la búsqueda de alelos relacionados con caracteres de interés.

Otro paso a realizar, es utilizar las entradas preseleccionadas respecto a la variabilidad de los genes $e I F 4 E$ y $e I F(i s o) 4 E$ para la búsqueda de nuevas resistencias a otros virus. La combinación de mutaciones en los genes eIF4E y eIF(iso)4E proporcionan resistencia a virus que afectan al pimiento, Pepper veinal mottle virus (PVMV) (Ruffel et al., 2006; Rubio et al., 2009) y Chilli veinal mottle virus (ChiVMV) (Hwang et al., 2009). También hay ejemplos de mutaciones en el factor de iniciación eIF4E responsables de las resistencias identificadas frente a otras familias virales. Así una mutación en el exón 1 (T99stopcodon) del gen eIF4E genera resistencia al Cucumber mosaic virus (CMV) de la familia Bromoviridae (Yoshii et al., 2004). Aparte, en el melón la mutación H228L (exón 5) del alelo H.4 del gen eIF4E controla la resistencia frente al Melon necrotic spot virus (MNSV) de la familia Tombusviridae (Nieto et al., 2007). En consecuencia, la colección de entradas con las distintas combinaciones posibles de los alelos pvr2 y pvr6, identificados en la plataforma de 
EcoTILLING, es un excelente banco de ensayos para la búsqueda de resistencia a otros virus de ARN. 
5. CONCLUSIONES 

1. Una plataforma de EcoTILLING, basada en ADN complementario y ADN genómico de 233 entradas de diferentes especies del género Capsicum ( $C$. annuum, $C$. chinense, $C$. frutescens, $C$. baccatum y $C$. pubescens), se ha puesto a punto para la identificación de variantes alélicas.

2. La utilización del ADNc como material de partida en la técnica EcoTILLING no se había descrito previamente. El EcoTILLING basado en el ADNc ha permitido reducir el número de amplificaciones y reacciones enzimáticas por muestra. Este enfoque también ha resuelto el problema de amplificar el gen candidato en diferentes especies como consecuencia de los cambios nucleotídicos en la hibridación de los cebadores.

3. La plataforma de EcoTILLING desarrollada se ha rastreado para la identificación de variantes alélicas de genes implicados en la resistencia a virosis, eIF4E y eIF(iso)4E. Esta plataforma muestra un elevado grado de variabilidad al identificarse 36 SNPs en las diferentes secuencias del gen $e I F 4 E$ y 26 SNPs en las secuencias del eIF(iso)4E. Este nivel de polimorfismo puede ser debido a la selección de las entradas, basada en los centros geográficos de mayor diversidad del pimiento.

4. Se detectaron 21 haplotipos del gen $e I F 4 E$ que codifican 19 proteínas diferentes y 15 haplotipos del gen $e I F(i s o) 4 E$ que codifican 10 proteínas. 14 proteínas eIF4E y 9 eIF(iso)4E no se habían descrito previamente. En conclusión, la plataforma de EcoTILLING contiene una buena representación de la variabilidad del género Capsicum.

5. A partir de la caracterización de 31 entradas, las cuales representan distintas combinaciones de los alelos eIF4E y eIF(iso) $4 E$, se identificaron cinco nuevos alelos del gen $e I F 4 E$ resistentes al virus $\mathrm{Y}$ de la patata: $p v r 2^{10}, p v r 2^{11}, p v r 2^{12}$, $p v r 2^{13}$ y $p v r 2^{14}$. Otros cuatro nuevos alelos del gen $e I F 4 E$ muestran una respuesta tolerante al aislado PVY-F14K: $p v r 2^{17}, p v r 2^{19}, p v r 2^{20}$ y $p v r 2^{22}$. 
6. Los resultados tras la inoculación mecánica con el aislado TEV-7DA han permitido identificar cinco nuevos alelos eIF4E relacionados con las respuestas de tolerancia al TEV. Las entradas que contienen los alelos $p v r 2^{10}, p v r 2^{11}, p v r 2^{12}$, $p v r 2^{13}$ o $p v r 2^{14}$ presentan el mismo nivel de tolerancia que las entradas con alguno de los dos alelos publicados como resistentes al TEV: $p v r 1$ y $p v r 2^{2}$. Estas entradas tolerantes son asintomáticas o desarrollan síntomas muy leves en las hojas, sin repercusión observable en los estadios del fruto.

7. Las proteínas eIF4E codificadas por los alelos que confieren resistencia al PVY y tolerancia al TEV contienen sustituciones aminoacídicas en las regiones exónicas I o II, las cuales pueden comprometer el ciclo de estos virus.

8. Los datos obtenidos a partir del estudio genético con la mejor representación de entradas de las especies $C$. chinense, $C$. frutescens, $C$. baccatum y $C$. pubescens, confirman la agrupación de las especies domesticadas en los distintos complejos (C. annuum, C. baccatum y $C$. pubescens) y la estrecha relación entre $C$. chinense y $C$. frutescens.

9. Las especies silvestres $C$. cardenasii y $C$. eximium se agrupan como una única especie variable en el complejo $C$. pubescens. Los resultados indican que $C$. praetermissum y $C$. baccatum son especies distintas que forman un grupo compacto en el complejo C. baccatum. Por otra parte, $C$. chacoense muestra una estrecha relación con las especies del complejo de $C$. baccatum mientras $C$. tovarii no pertenece a ningún complejo.

10. Los análisis basados en los microsatélites y AFLPs indican que en C. chinense, C. baccatum y $C$. pubescens los materiales procedentes de Bolivia, Ecuador y Perú muestran una diferenciación genética. No obstante, ninguna subestructuración regional se identificó en las especies analizadas.

11. A pesar de ser Bolivia el área nuclear del pimiento, se ha identificado una variabilidad genética similar en Ecuador y Perú para diferentes especies del género Capsicum. Este resultado valida la diversidad genética identificada en cada 
país como diferente e importante para ser utilizada en programas de mejora del pimiento. 

6. BIBLIOGRAFÍA 

Aguilar-Melendez A., Peter L., Morrell., Mikeal L. R., Seung-Chul K. (2009) Genetic diversity and structure in semiwild and domesticated chiles (Capsicum annиum; Solanaceae) from Mexico. American Journal of Botany, 96, 1190-1202.

Ahlquist P., Noueiry A. O., Lee W. M., Kushner D. B., Dye B. T. (2003) Host Factors in Positive-Strand RNA Virus Genome Replication. Journal of Virology, 77, 81818186.

Albar L., Bangratz-Reyser M., Hebrard E., Ndjiondjop M. N., Jones M., Ghesquiere A. (2006) Mutations in the eIF(iso)4G translation initiation factor confer high resistance of rice to Rice yellow mottle virus. Plant Journal, 47, 417-426.

Allard R. W. (1960) Principles of plant breeding. John Wiley \& Sons, New York.

Amari K., Gonzalez-Ibeas D., Gomez P., Sempere R. N., Sanchez-Pina M. A., Aranda M. A., Diaz-Pendon J. A., Navas-Castillo J., Moriones E., Blanca J., HernandezGallardo M. D., Anastasio G. (2008) Tomato torrado virus is transmitted by Bemisia tabaci and infects pepper and eggplant in addition to tomato. Plant Disease, 92, 1139-1139.

AVRDC (1999). Off-season tomato, pepper and eggplant. In AVRDC 1998 Progress Report, Tainan, 20-30.

Barkley N. A., Wang M. L., Gillaspie A. G., Dean R. E., Pederson G. A., Jenkins T. M. (2008) Discovering and verifying DNA polymorphisms in a mung bean $V$. radiata (L.) R. Wilczek collection by EcoTILLING and sequencing. BMC Research Notes, 1,28 .

Berkmortel van den L. G. (1977) Breeding pepper for resistance to a strain of TMV. III EUCARPIA Meeting on Genetics and Breeding of Capsicum and Eggplant, Avignon-Montfavet, 89-92.

Betti L., Tanzi M., Canova A. (1986) Genes for resistance in Capsicum and TMV pepper strains. VI EUCARPIA Meeting on Genetics and Breeding on Capsicum and Eggplant, Zaragoza, 173-176.

Black L. L., Green S. K., Hartman G. L., Poulos J. M. (1991) Pepper Diseases: A Field Guide. Asian Vegetable Research and Development Center Publication, Tainan, 347-445.

Blanca J. M., Prohens J., Anderson G. J., Zuriaga E., Canizares J., Nuez F. (2007) AFLP and DNA sequence variation in an Andean domesticate, pepino (Solanum muricatum, Solanaceae): Implications for evolution and domestication. American Journal of Botany, 94, 1219-1229. 
Bornet B., Goraguer F., Joly G., Branchard M. (2002) Genetic diversity in European and Argentinian cultivated potatoes (Solanum tuberosum subsp tuberosum) detected by Inter-Simple Sequence Repeats (ISSRs). Genome, 45, 481-484.

Bosland P. W., Votava E. J. (2000) Peppers: Vegetable and spice Capsicums. CAB International, Wallingford.

Boukema I. W. (1980) Allelism of genes-controlling resistance to TMV in Capsicum L. Euphytica, 29, 433-439.

Boukema I. W. (1984) Resistance to TMV in Capsicum chacoense Hunz. is governed by an allele of the L-locus. Capsicum Newsletter, 3, 47-48.

Browning K. S. (1996) The plant translation apparatus. Plant Molecular Biology, 32, 107-144.

Browning K. S., Webster C., Roberts J. K. M., Ravel J. M. (1992) Identification of an isozyme form of protein-synthesis initiation-factor 4F in plants. Journal of Biological Chemistry, 267, 10096-10100.

Bruun-Rasmussen M., Moller I. S., Tulinius G., Hansen J. K. R., Lund O. S., Johansen I. E. (2007) The same allele of translation initiation factor 4E mediates resistance against two potyvirus spp. in Pisum sativum. Molecular Plant-Microbe Interactions, 20, 1075-1082.

Cañizares J., Nuez F. (2010) Descubrimiento de la variabilidad alélica en colecciones de germoplasma: EcoTILLING. En: Mejora genética y recursos fitogenéticos: "Nuevos avances en la conservación y utilización de los recursos fitogenéticos". Eds: Carrillo J. M., Diez M. J., Pérez de la Vega M., Nuez F. Centro de Publicaciones del Ministerio de Medio Ambiente y Medio Rural y Marino, Madrid.

Caranta C., Thabuis A., Palloix A. (1999) Development of a CAPS marker for the Pvr4 locus: a tool for pyramiding potyvirus resistance genes in pepper. Genome, 42:1111-1116.

Cebolla-Cornejo J., Soler S., Gomar B., Soria M. D., Nuez F. (2003) Screening Capsicum germplasm for resistance to Tomato spotted wilt virus (TSWV). Annals of Applied Biology, 143, 143-152.

Charron C., Nicolai M., Gallois J. L., Robaglia C., Moury B. T., Palloix A., Caranta C. (2008) Natural variation and functional analyses provide evidence for co-evolution between plant eIF4E and potyviral VPg. Plant Journal, 54, 56-68.

Choong C. Y. (1998) DNA polymorphisms in the study of relationships and evolution in Capsicum. PhD Thesis, University of Reading. 
Comai L., Young K., Till B. J., Reynolds S. H., Greene E. A., Codomo C. A., Enns L. C., Johnson J. E., Burtner C., Odden A. R., Henikoff S. (2004) Efficient discovery of DNA polymorphisms in natural populations by EcoTILLING. Plant Journal, 37, 778-786.

Costa García J. (2002) El pimiento con destino a la industria en España. Horticultura, $163,409-411$.

Crosby K. M. (2008) Pepper. In Vegetables II (volume 2). Eds: Prohens J., Nuez F., Carena M. J. Springer, New York, 221-248.

De Swart E. A. M (2007) Potential for breeding sweet pepper adapted to cooler growing conditions. A physiological and genetic analysis of growth traits in Capsicum. $\mathrm{PhD}$ Thesis, Wageningen University.

Deom C. M., Murphy J. F., Paguio O. R. (1997) Resistance to Tobacco etch virus in Capsicum annuum: inhibition of virus RNA accumulation. Molecular PlantMicrobe Interactions, 10, 917-921.

Djian-Caporalino C., Pijarowski L., Fazari A., Samson M., Gaveau L., O’Byrne C., Lefebvre V., Caranta C., Palloix A., Abad P. (2001) High-resolution genetic mapping of the pepper (Capsicum annuum L.) resistance loci Me3 and Me4 conferring heat stable resistance to root-knot nematodes (Meloidogyne spp.). Theoretical and Applied Genetics, 103, 592-600.

Dogimont C., Palloix A., Daubze A. M., Marchoux G., Selassie K. G., Pochard E. (1996) Genetic analysis of broad spectrum resistance to potyviruses using doubled haploid lines of pepper (Capsicum annuum L). Euphytica, 88, 231-239.

Dong C. M., Vincent K., Sharp P. (2009) Simultaneous mutation detection of three homoeologous genes in wheat by High Resolution Melting analysis and Mutation Surveyor (R). BMC Plant Biology, 9.

Dreher T. W., Miller W. A. (2006) Translational control in positive strand RNA plant viruses. Virology, 344, 185-197.

Elias R., Till B. J., Mba C., Al-Safadi B. (2009) Optimizing TILLING and ECOTILLING techniques for potato (Solanum tuberosum L). BMC Research Notes, 2, 141.

Eshbaugh W. H. (1976) Genetic and biochemical systematic studies of chili peppers (Capsicum-Solanaceae). Bulletin of the Torrey Botanical Club, 102, 396-403.

FAO (2011). FAOSTAT. Base de datos estadísticos. http://faostat.fao.org/site/339/default.aspx 
Fery R. L., Thies J. A. (1997) Evaluation of Capsicum chinense Jacq cultigens for resistance to the southern root-knot nematode. Hortscience, 32, 923-926.

Flor H. H. (1947) Host-parasite interaction in flax rust. Its genetics and other implications. Phytopathology, 45, 680-685.

Flor H. H. (1971) Current status of the gene-for-gene concept. Annual Review of Phytopathology, 9, 275-296.

Fraser R. S. (1990) The genetics of resistance to plant viruses. Annual Review of Phytopathology, 28, 179-200.

Fraser R. S. (1992) The genetics of plant-virus interactions: implications for plant breeding. Euphytica, 63, 175-185.

Furini A., Wunder J. (2004) Analysis of eggplant (Solanum melongena)-related germplasm: morphological and AFLP data contribute to phylogenetic interpretations and germplasm utilization. Theoretical and Applied Genetics, 108, 197-208.

Gady A. L. F., Hermans F. W. K., Van de Wal M., Van Loo E. N., Visser R. G. F., Bachem C. W. B. (2009) Implementation of two high through-put techniques in a novel application: detecting point mutations in large EMS mutated plant populations. Plant Methods, 5.

Galeano C. H., Gomez M., Rodriguez L. M., Blair M. W. (2009) CEL I Nuclease Digestion for SNP Discovery and Marker Development in Common Bean (Phaseolus vulgaris L.). Crop Science, 49, 381-394.

Gao Z. H., Johansen E., Eyers S., Thomas C. L., Noel Ellis T. H., Maule A. J. (2004) The potyvirus recessive resistance gene, $s b m l$, identifies a novel role for translation initiation factor eIF4E in cell-to-cell trafficking. Plant Journal, 40, 376-385.

García P. (2004) Herramientas biotecnológicas y uso de recursos fitogenéticos. En: Resistencia genética a patógenos vegetales. Eds: Nuez F., Pérez de la Vega M., Carrillo J. M. Editorial de la UPV, Valencia.

Geleta L. F., Labuschagne M. T., Viljoen C. D. (2005) Genetic variability in pepper (Capsicum annuиm L.) estimated by morphological data and Amplified Fragment Length Polymorphism markers. Biodiversity and Conservation, 14, 2361-2375.

Gil-Ortega R. (1990) Resistencia a Phytopthora capsici L. en pimiento. Colección Tesis Doctorales INIA. MAPA, Madrid.

Gilchrist E. J., Haughn G. W., Ying C. C., Otto S. P., Zhuang J., Cheung D., Hamberger B., Aboutorabi F., Kalynyak T., Johnson L., Bohlmann J., Ellis B. E., Douglas C. J., Cronk Q. C. B. (2006) Use of EcoTILLING as an efficient SNP discovery tool 
to survey genetic variation in wild populations of Populus trichocarpa. Molecular Ecology, 15, 1367-1378.

Gingras A. C., Raught B., Sonenberg N. (1999) eIF4 initiation factors: effectors of mRNA recruitment to ribosomes and regulators of translation. Annual Review of Biochemistry, 68, 913-963.

Grube R. C., Blauth J. R., Arnedo-Andrés M. S., Caranta C., Jahn M. K. (2000) Identification and comparative mapping of a dominant potyvirus resistance gene cluster in Capsicum. Theoretical and Applied Genetics, 101, 852-859.

Guzman F. A., Ayala H., Azurdia C., Duque M. C., de Vicente M. C. (2005) AFLP assessment of genetic diversity of Capsicum genetic resources in Guatemala: Home gardens as an option for conservation. Crop Science, 45, 363-370.

Hajjar R., Hodgkin T. (2007) The use of wild relatives in crop improvement: a survey of developments over the last 20 years. Euphytica, 156, 1-13.

Hanacek P., Vyhnanek T., Rohrer M., Cieslarova J., Stavelikova H. (2009) DNA polymorphism in genetic resources of red pepper using microsatellite markers. Horticultural Science, 36, 127-132.

Hendy H., Dalmasso A., Cardin M. C. (1985) Differences in resistant Capsicum annuum attacked by different Meloidogyne species. Nematologica, 31, 72-78.

Hunziker A. T. (1979) South American Solanaceae: a synoptic survey. Linnean Society Symposium Series, 7, 49-85.

Hwang J., Li J., Liu W. Y., An S. J., Cho H., Her N., Yeam I., Kim D., Kang B. C. (2009) Double mutations in eIF4E and eIFiso4E confer recessive resistance to Chilli veinal mottle virus in pepper. Molecules and Cells, 27, 329-336.

Ince A. G., Karaca M., Onus A. N. (2010) Genetic Relationships Within and Between Capsicum Species. Biochemical Genetics, 48, 83-95.

Jahn M., Paran I., Hoffmann K., Radwanski E. R., Livingstone K. D., Grube R. C., Aftergoot E., Lapidot M., Moyer J. W. (2000) Genetic mapping of the Tsw locus for resistance to the tospovirus Tomato spotted wilt virus in Capsicum spp. and its relationship to the $S w-5$ gene for resistance to the same pathogen in tomato. Molecular Plant Microbe-Interactions, 13, 673-682.

Janssen D., Saez E., Segundo E., Martín G., Gil F., Cuadrado I. M. (2005) Capsicum annuum - a new host of Parietaria mottle virus in Spain. Plant Pathology, 54, 567567.

Johnson R. (1984) A Critical Analysis of Durable Resistance. Annual Review of Phytopathology, 22, 309-330. 
Jones J. B., Minsavage G. V., Roberts P. D., Johnson R. R., Kousik C. S., Subramanian S., Stall R. E. (2002) A nonhypersensitive resistance in pepper to the bacterial spot pathogen is associated with two recessive genes. Phytopathology, 92, 273-277.

Jordá C. (2006) Enfermedades virales del pimiento. http://www.horticom.com/tematicas/pimientos/pdf/capitulo8.pdf

Kadaru S. B., Yadav A. S., Fjellstrom R. G., Oard J. H. (2006) Alternative EcoTILLING protocol for rapid, cost-effective single-nucleotide polymorphism discovery and genotyping in rice (Oryza sativa L.). Plant Molecular Biology Reporter, 24, 3-22.

Kang B. C., Yeam I., Frantz J. D., Murphy J. F., Jahn M. M. (2005) The pvrl locus in Capsicum encodes a translation initiation factor eIF4E that interacts with Tobacco etch virus VPg. Plant Journal, 42, 392-405.

Kanyuka K., Druka A., Caldwell D. G., Tymon A., McCallum N., Waugh R., Adams M. J. (2005) Evidence that the recessive bymovirus resistance locus rym4 in barley corresponds to the eukaryotic translation initiation factor $4 \mathrm{E}$ gene. Molecular Plant Pathology, 6, 449-458.

Karp A., Kresovich S., Bhat K. V., Ayad W. G., Hodgkin. T. (1997) Molecular tools in plant genetic resources conservation: a guide to the technologies. IPGRI Technical Bulletin $\mathrm{N}^{\mathrm{O}} 2$, Rome.

Kyle M. M., Palloix A. (1997) Proposed revision of nomenclature for potyvirus resistance genes in Capsicum. Euphytica, 97, 183-188.

Lefebvre V., Goffinet B., Chauvet J. C., Caromel B., Signoret P., Brand R., Palloix A. (2001) Evaluation of genetic distances between pepper inbred lines for cultivar protection purposes: comparison of AFLP, RAPD and phenotypic data. Theoretical and Applied Genetics, 102, 741-750.

Lellis A. D., Kasschau K. D., Whitham S. A., Carrington J. C. (2002) Loss-ofsusceptibility mutants of Arabidopsis thaliana reveal an essential role for eIF(iso)4E during potyvirus infection. Current Biology, 12, 1046-1051.

Leonard S., Plante D., Wittmann S., Daigneault N., Fortin M. G., Laliberte J. F. (2000) Complex formation between potyvirus VPg and translation eukaryotic initiation factor 4E correlates with virus infectivity. Journal of Virology, 74, 7730-7737.

Li Y. C., Korol A. B., Fahima T., Nevo E. (2004) Microsatellites within genes: Structure, function, and evolution. Molecular Biology and Evolution, 21, 991-1007.

Ling K. S., Harris K. R., Meyer J. D. F., Levi A., Guner N., Wehner T. C., Bendahmane A., Havey M. J. (2009) Non-synonymous single nucleotide polymorphisms in the 
watermelon eIF4E gene are closely associated with resistance to Zucchini yellow mosaic virus. Theoretical and Applied Genetics, 120, 191-200.

Loaiza-Figueroa F., Ritland K., Laborde-Cancino J. A., Tanksley S. D. (1989) Patterns of genetic variation of the genus Capsicum (Solanaceae) in Mexico. Plant Systematics and Evolution, 165, 159-188.

MARM (2011). http://www.marm.es/es/estadistica/temas/default.aspx

Maroto J. V. (2002) Horticultura herbácea especial. Mundi-Prensa, Madrid.

Martín I. (2001) Conservación de recursos fitogenéticos. Ministerio de Agricultura, Pesca y Alimentación, Madrid.

Matsunaga H., Saito T., Hirai M., Nunome T., Yoshida T., (2003) DNA markers linked to Pepper mild mottle virus (PMMoV) resistant locus (L4) in Capsicum. Journal of the Japanese Society for Horticultural Science, 72, 218-220.

McDonald B. A., Linde C. (2002) Pathogen population genetics, evolutionary potential, and durable resistance. Annual Review of Phytopathology, 40, 349-379.

McLeod M. J, Eshbaugh W. H., Guttman S. I. (1979a) A pre-liminary biochemical systematic study of the genus Capsicum-Solanaceae. In: The Biologyand Taxonomy of the Solanaceae. Eds: Hawkes J. G., Lester R. N., Skelding A. D. Academic Press, New York, 701-714.

McLeod M. J., Eshbaugh W. H., Guttman S. I. (1979b) Electrophoretic study of Capsicum (Solanaceae) - purple flowered taxa. Bulletin of the Torrey Botanical Club, 106, 326-333.

McLeod M. J., Guttman S. I., Eshbaugh W. H., Rayle R. E. (1983) An electrophoretic study of evolution in Capsicum (Solanaceae). Evolution, 37, 562-574.

McLeod M. J., Guttman S. I., Eshbaugh W. H. (1982) Early evolution of chili peppers (Capsicum). Economic Botany, 36, 361-368.

Mejlhede N., Kyjovska Z., Backes G., Burhenne K., Rasmussen S. K., Jahoor A. (2006) EcoTILLING for the identification of allelic variation in the powdery mildew resistance genes mlo and Mla of barley. Plant Breeding, 125, 461-467.

Miller J. C., Tanksley S. D. (1990) RFLP analysis of phylogenetic-relationships and genetic-variation in the genus Lycopersicon. Theoretical and Applied Genetics, 80, 437-448.

Molchova E., Michailova M. (1982) On the interspecific crossability between Capsicum annuum L. and Capsicum pendulum Willd. Capsicum Newsletter, 1, 38-40. 
Morales M. (2005) Identificación de un candidato para el gen $n s v$ que confiere resistencia al virus de las manchas necróticas del melón (MNSV) mediante clonaje posicional. Tesis doctoral. Universidad Autónoma de Barcelona.

Moury B., Morel C., Johansen E., Guilbaud L., Souche S., Ayme V., Caranta C., Palloix A., Jacquemond M. (2004) Mutations in Potato virus $Y$ genome-linked protein determine virulence toward recessive resistances in Capsicum annuиm and Lycopersicon hirsutum. Molecular Plant-Microbe Interactions, 17, 322-329.

Murphy J. F., Blauth J. R., Livingstone K. D., Lackney V. K., Jahn M. K. (1998) Genetic mapping of the pvrl locus in Capsicum spp, and evidence that distinct potyvirus resistance loci control responses that differ at the whole plant and cellular levels. Molecular Plant-Microbe Interactions, 11, 943-951.

Naderpour M., Lund O. S., Larsen R., Johansen E. (2010) Potyviral resistance derived from cultivars of Phaseolus vulgaris carrying $b c-3$ is associated with the homozygotic presence of a mutated eIF4E allele. Molecular Plant Pathology, 11, 255-263.

Nicaise V., German-Retana S., Sanjuan R., Dubrana M. P., Mazier M., Maisonneuve B., Candresse T., Caranta C., Le Gall O. (2003) The eukaryotic translation initiation factor 4E controls lettuce susceptibility to the potyvirus Lettuce mosaic virus. Plant Physiology, 132, 1272-1282.

Nieto C., Piron F., Dalmais M., Marco C. F., Moriones E., Gomez-Guillamon M. L., Truniger V., Gomez P., Garcia-Mas J., Aranda M. A., Bendahmane A. (2007) EcoTILLING for the identification of allelic variants of melon eIF4E, a factor that controls virus susceptibility. BMC Plant Biology, 7.

Noueiry A. O., Chen J., Ahlquist P. (2000). A mutant allele of essential, general translation initiation factor DED1 selectively inhibits translation of a viral mRNA. Proceedings of the National Academy of Sciences, 97, 12985-12990.

Nuez F., Gil R., Costa J. (1996) El cultivo de pimientos, chiles y ajies. Mundi-Prensa, Madrid.

Onus A. N., Pickersgill B. (2004) Segregation of morphological and isozyme markers in a cross of Capsicum baccatum and Capsicum cardenasii. Israel Journal of Plant Sciences, 52, 37-44.

Papa R., Gepts P. (2003) Asymmetry of gene flow and differential geographical structure of molecular diversity in wild and domesticated common bean (Phaseolus vulgaris L.) from Mesoamerica. Theoretical and Applied Genetics, 106, 239-250.

Pérez de la Vega M. (2010) El proceso de domesticación. En: Mejora genética y recursos fitogenéticos: "Nuevos avances en la conservación y utilización de los recursos fitogenéticos”. Eds: Carrillo J. M., Diez M. J., Pérez de la Vega M., Nuez 
F. Centro de Publicaciones del Ministerio de Medio Ambiente y Medio Rural y Marino, Madrid.

Pérez de la Vega M., García P. (2000) Análisis de la variación genética en las poblaciones. En: Los marcadores genéticos en la mejora vegetal. Eds: Nuez F., Carrillo J. M. Editorial UPV, Valencia.

Pickersgill B. (1971) Relationships between weedy and cultivated forms in some species of chili peppers (genus Capsicum). Evolution, 25, 683-691.

Pickersgill B. (1988) The genus Capsicum - a multidisciplinary approach to the taxonomy of cultivated and wild plants. Biologisches Zentralblatt, 107, 381-389.

Pickersgill B. (1991) Cytogenetics and evolution of Capsicum L. In: Chromosome engineering in plants: genetics, breeding, evolution. Eds: Tsuchiya T., Gupta P. K. Elsevier, Amsterdam, 139-160.

Plank van der J. E. (1982) Host-pathogen interaction in plant disease. Academic Press, New York.

Polston J. E., Cohen L., Sherwood T. A., Ben-Joseph R., Lapidot M. (2006) Capsicum species: Symptomless hosts and reservoirs of Tomato yellow leaf curl virus. Phytopathology, 96, 447-452.

Prohens J., Anderson G. J., Rodríguez-Burruezo A., Nuez F. (2003) Exploiting wild species for the genetic improvement of pepino (Solanum muricatum). Journal of Applied Botany, 77, 21-27.

Qing-Lin C., Kanchana-Udomkarn K., Jaunet T., Mongkolporn O. (2002) Inheritance of resistance to pepper anthracnose caused by Colletotrichum capsici. Capsicum and Eggplant Newsletter, 21, 85-88.

Ramos M. L., Huntley J. J., Maleki S. J., Ozias-Akins P. (2009) Identification and characterization of a hypoallergenic ortholog of Ara $h$ 2.01. Plant Molecular Biology, 69, 325-335.

Rigola D., van Oeveren J., Janssen A., Bonne A., Schneiders H., van der Poel H. J. A., van Orsouw N. J., Hogers R. C. J., de Both M. T. J., van Eijk M. J. T. (2009) HighThroughput Detection of Induced Mutations and Natural Variation Using KeyPoint (TM) Technology. Plos One, 4.

Robaglia C., Caranta C. (2006) Translation initiation factors: a weak link in plant RNA virus infection. Trends in Plant Science, 11, 40-45.

Rodríguez J. A., Honorio F., Velázquez R., Gómez-Aguado M. (2001) Problemática fitosanitaria del pimiento en Extremadura. Vida Rural, 46. 
Rodriguez J. M., Berke T., Engle L., Nienhuis J. (1999) Variation among and within Capsicum species revealed by RAPD markers. Theoretical and Applied Genetics, 99, 147-156.

Rosenthal J. P., Dirzo R, (1997) Effects of life history, domestication and agronomic selection on plant defense against insects: Evidence from maizes and wild relatives. Evolutionary Ecology, 11, 337-355.

Rubio M., Nicolai M., Caranta C., Palloix A. (2009) Allele mining in the pepper gene pool provided new complementation effects between pvr2-eIF4E and pvr6eIF(iso)4E alleles for resistance to Pepper veinal mottle virus. Journal of General Virology, 90, 2808-2814.

Ruffel S., Dussault M. H., Palloix A., Moury B., Bendahmane A., Robaglia C., Caranta C. (2002) A natural recessive resistance gene against Potato virus $Y$ in pepper corresponds to the eukaryotic initiation factor 4E (eIF4E). Plant Journal, 32, 10671075.

Ruffel S., Gallois J. L., Lesage M. L., Caranta C. (2005) The recessive potyvirus resistance gene pot-1 is the tomato orthologue of the pepper pvr2-eIF4E gene. Molecular Genetics and Genomics, 274, 346-353.

Ruffel S., Gallois J. L., Moury B., Robaglia C., Palloix A., Caranta C. (2006) Simultaneous mutations in translation initiation factors eIF4E and eIF(iso) $4 E$ are required to prevent Pepper veinal mottle virus infection of pepper. Journal of General Virology, 87, 2089-2098.

Russell J. R., Fuller J. D., Macaulay M., Hatz B. G., Jahoor A., Powell W., Waugh R. (1997) Direct comparison of levels of genetic variation among barley accessions detected by RFLPs, AFLPs, SSRs and RAPDs. Theoretical and Applied Genetics, 95, 714-722.

Ryzhova N. N., Kochieva E. Z. (2004) Analysis of microsatellite loci of the chloroplast genome in the genus Capsicum (pepper). Russian Journal of Genetics, 40, 892-896.

Sachs A. B., Varani G. (2000) Eukaryotic translation initiation: there are (at least) two sides to every story. Nature Structural Biology, 7, 356-361.

Schaad M. C., Anderberg R. J., Carrington J. C. (2000) Strain-specific interaction of the Tobacco etch virus Nla protein with the translation initiation factor elF4E in the yeast two-hybrid system. Virology, 273, 300-306.

Shaw N., Cantliffe D. J. (2003) Color your world. American Vegetable Grower, 51.

Sifres A., Blanca J., Nuez F. (2010) Pattern of genetic variability of Solanum habrochaites in its natural area of distribution. Genetic Resources and Crop Evolution. doi: 10.1007/s10722-010-9578-0. 
Singh J., Thakur M. R., Pochard E. (1977) Genetics of resistance to Tobacco mosaic virus, Cucumber mosaic virus and Leaf curl virus in hot pepper (Capsicum annuum L.). III Congress of EUCARPIA on Genetics and Selection of Pepper, 119-126.

Smith P. G., Villalon B., Villa P. L. (1987) Horticultural classification of peppers grown in the United States. HortScience, 22, 11-13.

Soler S., Nuez F. (2004) Genes de resistencia en cultivos hortícolas. En: Resistencia genética a patógenos vegetales. Eds: Nuez F., Pérez de la Vega M., Carrillo J. M. Editorial de la UPV, Valencia.

Spooner D. M., McLean K., Ramsay G., Waugh R., Bryan G. J. (2005) A single domestication for potato based on multilocus Amplified Fragment Length Polymorphism genotyping. Proceedings of the National Academy of Sciences of the United States of America, 102, 14694-14699.

Sudre C. P., Goncalves L. S. A., Rodrigues R., do Amaral A. T., Riva-Souza E. M., Bento C. D. (2010) Genetic variability in domesticated Capsicum spp as assessed by morphological and agronomic data in mixed statistical analysis. Genetics and Molecular Research, 9, 283-294.

Tam S. M., Lefebvre V., Palloix A., Sage-Palloix A. M., Mhiri C., Grandbastien M. A. (2009) LTR-retrotransposons Tnt1 and T135 markers reveal genetic diversity and evolutionary relationships of domesticated peppers. Theoretical and Applied Genetics, 119, 973-989.

Till B. J., Burtner C., Comai L., Henikoff S. (2004) Mismatch cleavage by single-strand specific nucleases. Nucleic Acids Research, 32, 2632-2641.

Till B. J., Jankowicz-Cieslak J., Sági L., Huynh O. A., Utsushi H., Swennen R., Terauchi R., Mba C. (2010) Discovery of nucleotide polymorphisms in the Musa gene pool by Ecotilling. Theoretical and Applied Genetics, 121(7), 1381-1389.

Till B. J., Reynolds S. H., Greene E. A., Codomo C. A., Enns L. C., Johnson J. E., Burtner C., Odden A. R., Young K., Taylor N. E., Henikoff J. G., Comai L., Henikoff S. (2003) Large-scale discovery of induced point mutations with highthroughput TILLING. Genome Research, 13, 524-530.

Tong N., Bosland P. W. (1999) Capsicum tovarii, a new member of the Capsicum baccatum complex. Euphytica, 109, 71-77.

Toquica S. P., Rodriguez F., Martinez E., Duque M. C., Tohme J. (2003) Molecular characterization by AFLPs of Capsicum germplasm from the Amazon Department in Colombia, characterization by AFLPs of Capsicum. Genetic Resources and Crop Evolution, 50, 639-647. 
Triques K., Piednoir E., Dalmais M., Schmidt J., Le Signor C., Sharkey M., Caboche M., Sturbois B., Bendahmane A. (2008) Mutation detection using ENDO1: Application to disease diagnostics in humans and TILLING and EcoTILLING in plants. BMC Molecular Biology, 9, 9.

Truniger V. Aranda M. A. (2009) Recessive resistance to plant viruses. Advances in virus research, $75,119-59$.

Tsujimoto Y., Numaga T., Ohshima K., Yano M. A., Ohsawa R., Goto D. B., Naito S., Ishikawa M. (2003) Arabidopsis tobamovirus multiplication (TOM) 2 locus encodes a transmembrane protein that interacts with TOM1. EMBO Journal, 22, 335-343.

Viruel M. A. (2010) Los marcadores moleculares en el análisis de la variabilidad y su manejo. En: Mejora genética y recursos fitogenéticos: "Nuevos avances en la conservación y utilización de los recursos fitogenéticos". Eds: Carrillo J. M., Diez M. J., Pérez de la Vega M., Nuez F. Centro de Publicaciones del Ministerio de Medio Ambiente y Medio Rural y Marino, Madrid.

Walker S. J., Bosland P. W. (1999) Inheritance of Phytophthora root rot and foliar blight resistance in pepper. Journal of the American Society for Horticultural Science, 124, 14-18.

Walsh B. M., Hoot S. B. (2001) Phylogenetic relationships of Capsicum (Solanaceae) using DNA sequences from two noncoding regions: The chloroplast atpB-rbcL spacer region and nuclear waxy introns. International Journal of Plant Sciences, $162,1409-1418$.

Wang G. X., Tan M. K., Suj A. R. C., Saitoh H., Terauchi R., Imaizumi T., Ohsako T., Tominaga T. (2007) Discovery of single-nucleotide mutations in acetolactate synthase genes by EcoTILLING. Pesticide Biochemistry and Physiology, 88, 143148.

Wang J., Sun J. Z., Liu D. C., Yang W. L., Wang D. W., Tong Y. P., Zhang A. M. (2008) Analysis of Pina and Pinb alleles in the micro-core collections of Chinese wheat germplasm by EcoTILLING and identification of a novel Pinb allele. Journal of Cereal Science, 48, 836-842.

Yeam I., Cavatorta J. R., Ripoll D. R., Kang B. C., Jahn M. M. (2007) Functional dissection of naturally occurring amino acid substitutions in eIF4E that confers recessive potyvirus resistance in plants. Plant Cell, 19, 2913-2928.

Yoon J. B., Park H. G. (2005) Trispecies bridge crosses, (Capsicum annuum x $C$. chinense) $\mathrm{x} C$. baccatum, as an alternative for introgression of anthracnose resistance from $C$. baccatum into $C$. annuum. Journal of the Korean Society for Horticultural Science, 46, 5-9. 
Yoon J. B., Yang D. C., Do J. W., Park H. G. (2006) Overcoming two post-fertilization genetic barriers in interspecific hybridization between Capsicum annuum and Capsicum baccatum for introgression of anthracnose resistance. Breeding Science, 56, 31-38.

Yoshii M., Nishikiori M., Tomita K., Yoshioka N., Kozuka R., Naito S., Ishikawa M. (2004) The Arabidopsis Cucumovirus multiplication 1 and 2 loci encode tip translation initiation factors 4E and 4G. Journal of Virology, 78, 6102-6111.

Zewdie Y., Bosland P. W. (2000) Capsaicinoid inheritance in an interspecific hybridization of Capsicum annuum x C-chinense. Journal of the American Society for Horticultural Science, 125, 448-453.

Zijlstra S., Purimahua C., Lindhout P. (1991) Pollen tube growth ininterspecific crosses between Capsicum species. HortScience, 26, 585-586.

Zuriaga E. (2009) Análisis de la variabilidad en poblaciones naturales de Solanum, secciones Lycopersicon y Basarthrum. Tesis doctoral, Universidad Politécnica de Valencia.

Zuriaga E., Blanca J. M., Cordero L., Sifres A., Blas-Cerdan W. G., Morales R., Nuez F. (2009b) Genetic and bioclimatic variation in Solanum pimpinellifolium. Genetic Resources and Crop Evolution, 56, 39-51.

Zuriaga E., Blanca J., Nuez F. (2009a) Classification and phylogenetic relationships in Solanum section Lycopersicon based on AFLP and two nuclear gene sequences. Genetic Resources and Crop Evolution, 56, 663-678. 

7. ANEXOS 

EcoTILLING in Capsicum species: searching for new virus resistances BMC GENOMICS 

Additional file 1: Capsicum spp. accessions analysed by EcoTILLING and their haplotypes $e I F 4 E$ and $e I F(i s o) 4 E$.

\begin{tabular}{|c|c|c|c|c|}
\hline Accession & Country & Species & eIF4E Haplotype & eIF(iso) $4 E$ Haplotype \\
\hline CDP000620 & Bolivia & C. аппиит & $e I F 4 E \_F 3$ & eIF(iso)4E_DI \\
\hline CDP001342 & Bolivia & C. аппиит & $e I F 4 E \_B I$ & eIF(iso)4E_Cl \\
\hline CDP006311 & Bolivia & C. аппиит & $e I F 4 E \_A l$ & eIF(iso)4E_C1 \\
\hline CDP005617 & Spain (Canary Islands) & C. аппиит & $e I F 4 E \_E 1$ & $e I F(i s o) 4 E \_D l$ \\
\hline CDP002683 & Spain (Canary Islands) & C. аппиит & $e I F 4 E \_E 1$ & eIF(iso)4E_Dl \\
\hline CDP004666 & Spain (Canary Islands) & C. аппиит & $e I F 4 E \_E 1$ & eIF(iso)4E_Cl \\
\hline CDP000458 & Spain (Canary Islands) & C. аппиит & $e I F 4 E \_E 1$ & eIF(iso)4E_Cl \\
\hline CDP003351 & Spain (Canary Islands) & C. аппиит & $e I F 4 E \_E 1$ & eIF(iso)4E_Cl \\
\hline CDP009414 & Spain (Canary Islands) & C. аппиит & $e I F 4 E \_B 1$ & eIF(iso)4E_Cl \\
\hline CDP007637 & Spain (Canary Islands) & C. аппиит & $e I F 4 E \_B 1$ & eIF(iso)4E_C1 \\
\hline CDP009549 & Spain (Canary Islands) & C. аппиит & $e I F 4 E \_B 1$ & eIF(iso)4E_Cl \\
\hline CDP004547 & Spain (Canary Islands) & C. аппиит & $e I F 4 E \_E 1$ & eIF(iso)4E_Dl \\
\hline CDP001135 & Spain (Canary Islands) & C. аппиит & $e I F 4 E \_E 1$ & eIF(iso)4E_DI \\
\hline CDP002657 & Spain (Canary Islands) & C. аппиит & $e I F 4 E \_B 1$ & eIF(iso)4E_DIC1 \\
\hline CDP006114 & Spain (Canary Islands) & C. аппиит & $e I F 4 E \_E 1$ & eIF(iso)4E_Cl \\
\hline CDP009074 & Spain (Canary Islands) & C. аппиит & $e I F 4 E \_E 1$ & eIF(iso)4E_C1 \\
\hline CDP001547 & Spain (Canary Islands) & C. аппиит & $e I F 4 E \_B 1$ & eIF(iso)4E_C1 \\
\hline CDP001246 & Spain (Canary Islands) & C. аппиит & $e I F 4 E \_B 1$ & $e I F($ iso $) 4 E \_D I$ \\
\hline CDP009688 & Spain (Canary Islands) & C. аппиит & $e I F 4 E \_B 1$ & eIF(iso)4E_DIC1 \\
\hline CDP007968 & Chile & C. аппиит & $e I F 4 E_{-} B 1$ & $e I F(i s o) 4 E_{-} C 1$ \\
\hline CDP004928 & Ecuador & C. аппиит & $e I F 4 E_{-} B 1$ & $e I F(i s o) 4 E_{-} C 1$ \\
\hline CDP004647 & Ecuador & C. аппиит & $e I F 4 E \_B 1$ & $e I F(i s o) 4 E_{-} C 1$ \\
\hline CDP007011 & Ecuador & C. аппиит & $e I F 4 E \_A I$ & $e I F(i s o) 4 E_{-} C l$ \\
\hline CDP002490 & Ecuador & C. аппиит & $e I F 4 E \_B I$ & eIF(iso)4E_DI \\
\hline CDP004354 & Ecuador & C. аппиит & $e I F 4 E \_E 1$ & eIF(iso)4E_Cl \\
\hline CDP008431 & Ecuador & C. аппиит & $e I F 4 E \_B 1$ & eIF(iso)4E_Dl \\
\hline CDP005444 & Ecuador & C. аппиит & $e I F 4 E \_A I$ & eIF(iso)4E_Cl \\
\hline CDP006433 & Ecuador & C. аппиит & $e I F 4 E \_E 1$ & eIF(iso)4E_Cl \\
\hline CDP005730 & Ecuador & C. аппиит & $e I F 4 E \_B 1$ & eIF(iso)4E_Cl \\
\hline CDP006188 & Peru & C. аппиит & $e I F 4 E \_A I$ & eIF(iso)4E_Cl \\
\hline CDP007530 & Bolivia & C. baccatum & $e I F 4 E \_F 1$ & eIF(iso)4E_Al \\
\hline CDP004710 & Bolivia & C. baccatum & $e I F 4 E_{-} Q 1$ & eIF(iso)4E_C4 \\
\hline CDP009326 & Bolivia & C. baccatum & $e I F 4 E \_F 1$ & eIF(iso)4E_Al \\
\hline CDP005775 & Bolivia & C. baccatum & eIF4E_LIF1 & $e I F(i s o) 4 E \_A l$ \\
\hline CDP004131 & Bolivia & C. baccatum & $e I F 4 E \_N 1$ & $e I F(i s o) 4 E \_F 1$ \\
\hline CDP009965 & Bolivia & C. baccatum & $e I F 4 E_{-} Q 1$ & eIF(iso)4E_C4 \\
\hline CDP001148 & Bolivia & C. baccatum & $e I F 4 E \_N 1 Q 1$ & eIF(iso)4E_C4 \\
\hline CDP002854 & Bolivia & C. baccatum & $e I F 4 E \_N 1$ & eIF(iso)4E_C4 \\
\hline
\end{tabular}




\begin{tabular}{|c|c|c|c|c|}
\hline Accession & Country & Species & eIF4E Haplotype & eIF(iso)4E Haplotype \\
\hline CDP004865 & Bolivia & C. baccatum & eIF4E_NI & $e I F(i s o) 4 E \_A l$ \\
\hline CDP002428 & Bolivia & C. baccatum & $e I F 4 E \_N 1$ & eIF(iso)4E_C4 \\
\hline CDP000467 & Bolivia & C. baccatum & $e I F 4 E \_N 1$ & eIF(iso)4E_C4 \\
\hline CDP001494 & Bolivia & C. baccatum & $e I F 4 E \_N 1$ & eIF(iso)4E_C4 \\
\hline CDP008578 & Bolivia & C. baccatum & eIF4E_OIFI & eIF(iso)4E_C4 \\
\hline CDP003981 & Bolivia & C. baccatum & $e I F 4 E \_Q 1 S h 1$ & eIF(iso)4E_C4 \\
\hline CDP009334 & Bolivia & C. baccatum & eIF4E_O1 & eIF(iso)4E_C4 \\
\hline CDP007575 & Bolivia & C. baccatum & $e I F 4 E_{-} Q 1$ & eIF(iso)4E_C4 \\
\hline CDP005929 & Bolivia & C. baccatum & $e I F 4 E_{-} Q 1$ & eIF(iso)4E_Al \\
\hline CDP009540 & Bolivia & C. baccatum & $e I F 4 E \_N 1$ & eIF(iso)4E_C4 \\
\hline CDP005581 & Bolivia & C. baccatum & $e I F 4 E \_L 1$ & eIF(iso)4E_C4 \\
\hline CDP004369 & Bolivia & C. baccatum & $e I F 4 E_{-} O 1 F 1$ & eIF(iso)4E_C3 \\
\hline CDP003911 & Bolivia & C. baccatum & eIF4E_LINI & eIF(iso)4E_C4 \\
\hline CDP002616 & Bolivia & C. baccatum & $e I F 4 E \_N 1$ & eIF(iso) $4 E_{-} C 4$ \\
\hline CDP000497 & Bolivia & C. baccatum & $e I F 4 E \_N 1$ & eIF(iso)4E_C4 \\
\hline CDP009725 & Bolivia & C. baccatum & eIF4E_OIFI & eIF(iso)4E_C3 \\
\hline CDP001024 & Bolivia & C. baccatum & $e I F 4 E_{-} Q 1$ & eIF(iso) $4 E_{-} C 4$ \\
\hline CDP005084 & Bolivia & C. baccatum & $e I F 4 E \_K 1$ & eIF(iso) $4 E_{-} C 4$ \\
\hline CDP006360 & Bolivia & C. baccatum & $e I F 4 E_{-} M I$ & eIF(iso) $4 E_{-} C 4$ \\
\hline CDP008052 & Bolivia & C. baccatum & $e I F 4 E_{-} M I$ & eIF(iso) $4 E_{-} C 4$ \\
\hline CDP004987 & Bolivia & C. baccatum & $e I F 4 E \_L 1$ & eIF(iso) $4 E_{-} C 4$ \\
\hline CDP000007 & Bolivia & C. baccatum & $e I F 4 E_{-} M I N 1$ & $e I F(i s o) 4 E_{-} F 1$ \\
\hline CDP003494 & Bolivia & C. baccatum & $e I F 4 E_{-} F 1$ & eIF(iso)4E_C4 \\
\hline CDP007825 & Bolivia & C. baccatum & $e I F 4 E_{-} M I$ & $e I F(i s o) 4 E_{-} F 1$ \\
\hline CDP006881 & Bolivia & C. baccatum & eIF4E_OIFI & eIF(iso) $4 E_{-} C 4$ \\
\hline CDP006234 & Bolivia & C. baccatum & $e I F 4 E_{-} F 1$ & eIF(iso)4E_C4 \\
\hline CDP004291 & Bolivia & C. baccatum & $e I F 4 E \_K 1$ & eIF(iso)4E_Al \\
\hline CDP007490 & Bolivia & C. baccatum & eIF4E_N1 & eIF(iso) $4 E_{-} C 4$ \\
\hline CDP005431 & Bolivia & C. baccatum & $e I F 4 E \_N 1$ & eIF(iso)4E_C4 \\
\hline CDP008886 & Bolivia & C. baccatum & $e I F 4 E \_N 1$ & eIF(iso)4E_C4 \\
\hline CDP007318 & Bolivia & C. baccatum & $e I F 4 E \_Q 1$ & eIF(iso) $4 E_{-} C 4$ \\
\hline CDP002320 & Bolivia & C. baccatum & $e I F 4 E \_K 1$ & eIF(iso)4E_C4 \\
\hline CDP004760 & Ecuador & C. baccatum & NO AMPLIFICATION & eIF(iso)4E_C4 \\
\hline CDP000447 & Ecuador & C. baccatum & $e I F 4 E \_F 1$ & eIF(iso)4E_Al \\
\hline CDP004429 & Ecuador & C. baccatum & $e I F 4 E_{-} F 1$ & eIF(iso)4E_C4 \\
\hline CDP007470 & Ecuador & C. baccatum & eIF4E_OI & eIF(iso)4E_Al \\
\hline CDP003497 & Ecuador & C. baccatum & $e I F 4 E_{-} F 1$ & eIF(iso)4E_Al \\
\hline CDP003174 & Ecuador & C. baccatum & $e I F 4 E_{-} F 1$ & eIF(iso)4E_Al \\
\hline CDP000624 & Ecuador & C. baccatum & $e I F 4 E_{-} F 1$ & eIF(iso)4E_C4 \\
\hline CDP004291 & Bolivia & C. baccatum & $e I F 4 E \_K 1$ & eIF(iso)4E_Al \\
\hline
\end{tabular}




\begin{tabular}{|c|c|c|c|c|}
\hline Accession & Country & Species & eIF4E Haplotype & eIF(iso)4E Haplotype \\
\hline CDP008397 & Ecuador & C. baccatum & eIF4E_K1 & eIF(iso) $4 E \_C 4$ \\
\hline CDP008448 & Ecuador & C. baccatum & $e I F 4 E_{-} F 1$ & eIF(iso)4E_Al \\
\hline CDP009158 & Ecuador & C. baccatum & $e I F 4 E_{-} F 1$ & eIF(iso)4E_C4 \\
\hline CDP003269 & Ecuador & C. baccatum & eIF4E_OI & eIF(iso) $4 E_{-} A l$ \\
\hline CDP009967 & Ecuador & C. baccatum & eIF4E_OI & eIF(iso) $4 E_{-} A l$ \\
\hline CDP007426 & Ecuador & C. baccatum & NO AMPLIFICATION & eIF(iso) $4 E_{-} A l$ \\
\hline CDP008419 & Ecuador & C. baccatum & NO AMPLIFICATION & eIF(iso) $4 E \_A l$ \\
\hline CDP003922 & Ecuador & C. baccatum & eIF4E_OI & eIF(iso)4E_C4 \\
\hline CDP005501 & Ecuador & C. baccatum & $e I F 4 E_{-} F 1$ & eIF(iso) $4 E_{-} A l$ \\
\hline CDP007475 & Ecuador & C. baccatum & $e I F 4 E \_K 1$ & eIF(iso)4E_C4 \\
\hline CDP001420 & Ecuador & C. baccatum & NO AMPLIFICATION & eIF(iso)4E_Al \\
\hline CDP003507 & Ecuador & C. baccatum & $e I F 4 E_{-} F 1$ & eIF(iso)4E_C4 \\
\hline CDP003451 & Ecuador & C. baccatum & $e I F 4 E_{-} F 1$ & eIF(iso)4E_C5 \\
\hline CDP000860 & Ecuador & C. baccatum & $e I F 4 E_{-} F 1$ & eIF(iso) $4 E_{-} C 4$ \\
\hline CDP008651 & Ecuador & C. baccatum & $e I F 4 E_{-} F 1$ & eIF(iso)4E_C4 \\
\hline CDP002074 & Ecuador & C. baccatum & $e I F 4 E_{-} F 1$ & eIF(iso) $4 E_{-} C 4$ \\
\hline CDP003484 & Ecuador & C. baccatum & $e I F 4 E_{-} F 1$ & eIF(iso) $4 E_{-} C 4$ \\
\hline CDP006686 & Ecuador & C. baccatum & $e I F 4 E_{-} F 1$ & eIF(iso) $4 E_{-} C 4$ \\
\hline CDP005839 & Ecuador & C. baccatum & $e I F 4 E \_F 1$ & eIF(iso) $4 E_{-} C 4$ \\
\hline CDP008002 & Ecuador & C. baccatum & $e I F 4 E_{-} F 1$ & eIF(iso) $4 E_{-} C 5$ \\
\hline CDP009055 & Ecuador & C. baccatum & $e I F 4 E \_F 1$ & eIF(iso) $4 E_{-} C 4$ \\
\hline CDP009599 & Ecuador & C. baccatum & $e I F 4 E_{-} F 1$ & eIF(iso) $4 E_{-} C 4$ \\
\hline CDP007258 & Ecuador & C. baccatum & $e I F 4 E \_F 1$ & eIF(iso)4E_C4 \\
\hline CDP001202 & Ecuador & C. baccatum & $e I F 4 E \_F 1$ & eIF(iso) $4 E_{-} C 4$ \\
\hline CDP000614 & Ecuador & C. baccatum & $e I F 4 E_{-} F 1$ & eIF(iso)4E_Al \\
\hline CDP002622 & Ecuador & C. baccatum & eIF4E_OI & eIF(iso)4E_Al \\
\hline CDP006411 & Ecuador & C. baccatum & NO AMPLIFICATION & eIF(iso)4E_C4 \\
\hline CDP007543 & Bolivia & C. chacoense & eIF4E_Cl & eIF(iso) $4 E_{-} E 1$ \\
\hline CDP008791 & Bolivia & C. chacoense & $e I F 4 E_{-} C l$ & eIF(iso)4E_E1 \\
\hline CDP008407 & Bolivia & C. chinense & $e I F 4 E \_H I$ & eIF(iso)4E_BI \\
\hline CDP009976 & Bolivia & C. chinense & $e I F 4 E \_F 3 H I$ & eIF(iso) $4 E_{-} B 1$ \\
\hline CDP007388 & Bolivia & C. chinense & $e I F 4 E_{-} F 3$ & eIF(iso)4E_BI \\
\hline CDP002521 & Bolivia & C. chinense & $e I F 4 E \_D 1$ & eIF(iso)4E_BI \\
\hline CDP004103 & Bolivia & C. chinense & $e I F 4 E \_I I$ & eIF(iso)4E_B1 \\
\hline CDP000090 & Bolivia & C. chinense & $e I F 4 E \_P 1$ & eIF(iso)4E_BI \\
\hline CDP007930 & Ecuador & C. chinense & $e I F 4 E_{-} F 3$ & eIF(iso)4E_BI \\
\hline CDP001969 & Ecuador & C. chinense & $e I F 4 E_{-} F 3$ & eIF(iso)4E_B1 \\
\hline CDP005040 & Ecuador & C. chinense & $e I F 4 E_{-} F 3$ & eIF(iso)4E_B1 \\
\hline CDP005295 & Ecuador & C. chinense & $e I F 4 E \_F 3$ & eIF(iso)4E_BI \\
\hline CDP003854 & Ecuador & C. chinense & $e I F 4 E \_F 3$ & eIF(iso)4E_BI \\
\hline
\end{tabular}




\begin{tabular}{|c|c|c|c|c|}
\hline Accession & Country & Species & eIF4E Haplotype & eIF(iso)4E Haplotype \\
\hline CDP009651 & Ecuador & C. chinense & eIF4E_G1 & $e I F(i s o) 4 E \_B I$ \\
\hline CDP000004 & Ecuador & C. chinense & $e I F 4 E_{-} F 3$ & eIF(iso) $4 E \_B 1$ \\
\hline CDP006248 & Ecuador & C. chinense & $e I F 4 E_{-} F 3$ & eIF(iso)4E_Bl \\
\hline CDP007645 & Ecuador & C. chinense & $e I F 4 E_{-} F 3$ & eIF(iso) $4 E \_B 1$ \\
\hline CDP001070 & Ecuador & C. chinense & $e I F 4 E_{-} F 3$ & eIF(iso) $4 E \_B 1$ \\
\hline CDP007782 & Ecuador & C. chinense & $e I F 4 E_{-} F 3$ & eIF(iso) $4 E_{-} B 1$ \\
\hline CDP008741 & Ecuador & C. chinense & $e I F 4 E \_P 1$ & $e I F(i s o) 4 E \_B 1$ \\
\hline CDP006774 & Ecuador & C. chinense & $e I F 4 E_{-} F 3$ & eIF(iso) $4 E \_B 1$ \\
\hline CDP006152 & Ecuador & C. chinense & $e I F 4 E \_D 1$ & $e I F(i s o) 4 E \_B I$ \\
\hline CDP008667 & Ecuador & C. chinense & $e I F 4 E_{-} F 3$ & $e I F(i s o) 4 E \_B 1$ \\
\hline CDP009144 & Ecuador & C. chinense & $e I F 4 E_{-} F 3$ & eIF(iso) $4 E \_B 1$ \\
\hline CDP006209 & Ecuador & C. chinense & $e I F 4 E_{-} F 3$ & $e I F(i s o) 4 E \_B I$ \\
\hline CDP007406 & Ecuador & C. chinense & $e I F 4 E_{-} F 3$ & eIF(iso)4E_BI \\
\hline CDP001182 & Ecuador & C. chinense & $e I F 4 E \_P l$ & eIF(iso)4E_BI \\
\hline CDP009473 & Ecuador & C. chinense & $e I F 4 E_{-} F 3$ & eIF(iso)4E_Bl \\
\hline CDP007700 & Ecuador & C. chinense & $e I F 4 E \_I I$ & eIF(iso)4E_BI \\
\hline CDP002693 & Ecuador & C. chinense & $e I F 4 E_{-} D 1$ & eIF(iso) $4 E_{-} B 1$ \\
\hline CDP008190 & Ecuador & C. chinense & $e I F 4 E \_I I$ & eIF(iso)4E_BI \\
\hline CDP006323 & Ecuador & C. chinense & $e I F 4 E \_I I$ & eIF(iso) $4 E \_B I$ \\
\hline CDP005852 & Ecuador & C. chinense & $e I F 4 E \_I I$ & eIF(iso) $4 E_{-} B 1$ \\
\hline CDP007864 & Ecuador & C. chinense & $e I F 4 E_{-} D 1$ & eIF(iso) $4 E \_B 1$ \\
\hline CDP001263 & Ecuador & C. chinense & $e I F 4 E \_B I$ & eIF(iso) $4 E \_B I$ \\
\hline CDP001186 & Ecuador & C. chinense & $e I F 4 E \_P 1$ & eIF(iso)4E_BI \\
\hline CDP009351 & Ecuador & C. chinense & $e I F 4 E \_F 3$ & eIF(iso) $4 E \_B 1$ \\
\hline CDP003764 & Ecuador & C. chinense & eIF4E_II & eIF(iso) $4 E \_B I$ \\
\hline CDP004946 & Ecuador & C. chinense & NO AMPLIFICATION & eIF(iso)4E_BI \\
\hline CDP002204 & Ecuador & C. chinense & $e I F 4 E \_I I$ & eIF(iso)4E_BI \\
\hline CDP001708 & Ecuador & C. chinense & $e I F 4 E \_F 3$ & eIF(iso) $4 E_{-} B 1$ \\
\hline CDP000486 & Ecuador & C. chinense & $e I F 4 E \_F 3$ & eIF(iso)4E_BI \\
\hline CDP005315 & Peru & C. chinense & $e I F 4 E \_I 1$ & eIF(iso)4E_BI \\
\hline CDP004427 & Bolivia & C. еximium & NO AMPLIFICATION & eIF(iso) $4 E_{-} K 1$ \\
\hline CDP008291 & Bolivia & C. eximium & NO AMPLIFICATION & eIF(iso)4E_BI \\
\hline CDP005465 & Bolivia & C. frutescens & $e I F 4 E \_F 3$ & eIF(iso)4E_C2 \\
\hline CDP008338 & Bolivia & C. frutescens & $e I F 4 E_{-} F 3$ & eIF(iso)4E_C2 \\
\hline CDP003661 & Ecuador & C. frutescens & $e I F 4 E_{-} F 3$ & eIF(iso)4E_BI \\
\hline CDP000538 & Ecuador & C. frutescens & $e I F 4 E \_F 3$ & eIF(iso)4E_C2 \\
\hline CDP004293 & Ecuador & C. frutescens & $e I F 4 E_{-} F 3$ & eIF(iso)4E_B1 \\
\hline CDP009897 & Ecuador & C. frutescens & $e I F 4 E_{-} F 3$ & eIF(iso)4E_B1 \\
\hline CDP000867 & Ecuador & C. frutescens & $e I F 4 E \_F 2 G 1$ & eIF(iso)4E_BI \\
\hline CDP005414 & Ecuador & C. frutescens & $e I F 4 E_{-} F 2 G 1$ & eIF(iso)4E_BI \\
\hline
\end{tabular}




\begin{tabular}{|c|c|c|c|c|}
\hline Accession & Country & Species & eIF4E Haplotype & eIF(iso)4E Haplotype \\
\hline CDP007379 & Ecuador & C. frutescens & NO AMPLIFICATION & eIF(iso)4E_Bl \\
\hline CDP004191 & Ecuador & C. frutescens & $e I F 4 E_{-} F 3$ & eIF(iso)4E_C2 \\
\hline CDP005036 & Ecuador & C. frutescens & $e I F 4 E \_F 2$ & eIF(iso)4E_C2 \\
\hline CDP003442 & Ecuador & C. frutescens & $e I F 4 E_{-} F 3$ & eIF(iso)4E_C2 \\
\hline CDP000437 & Ecuador & C. frutescens & $e I F 4 E_{-} F 3$ & eIF(iso) $4 E_{-} C 2$ \\
\hline CDP009220 & Ecuador & C. frutescens & $e I F 4 E_{-} F 3$ & $e I F(i s o) 4 E \_B 1$ \\
\hline CDP000035 & Ecuador & C. frutescens & $e I F 4 E \_F 3$ & eIF(iso)4E_Bl \\
\hline CDP007553 & Ecuador & C. frutescens & $e I F 4 E_{-} F 3$ & eIF(iso)4E_Bl \\
\hline CDP009247 & Ecuador & C. frutescens & eIF4E_F3 & eIF(iso)4E_Bl \\
\hline CDP004681 & Ecuador & C. frutescens & $e I F 4 E \_G 1$ & eIF(iso)4E_BI \\
\hline CDP008061 & Ecuador & C. frutescens & $e I F 4 E \_F 3$ & eIF(iso) $4 E_{-} B 1$ \\
\hline CDP002342 & Ecuador & C. frutescens & $e I F 4 E_{-} F 3$ & eIF(iso)4E_BI \\
\hline CDP008695 & Ecuador & C. frutescens & $e I F 4 E_{-} G 1$ & eIF(iso)4E_B1 \\
\hline CDP002520 & Ecuador & C. frutescens & $e I F 4 E_{-} F 3$ & eIF(iso) $4 E_{-} C 2$ \\
\hline CDP001016 & Ecuador & C. frutescens & $e I F 4 E \_F 3$ & eIF(iso)4E_BI \\
\hline CDP008391 & Ecuador & C. frutescens & $e I F 4 E_{-} F 3$ & eIF(iso)4E_BI \\
\hline CDP007030 & Ecuador & C. frutescens & $e I F 4 E_{-} F 3$ & eIF(iso)4E_B1 \\
\hline CDP000364 & Ecuador & C. frutescens & $e I F 4 E \_F 2$ & eIF(iso) $4 E_{-} B 1$ \\
\hline CDP006160 & Ecuador & C. frutescens & $e I F 4 E \_F 3$ & eIF(iso)4E_BI \\
\hline CDP000973 & Ecuador & C. frutescens & $e I F 4 E \_G l$ & eIF(iso)4E_C2 \\
\hline CDP008389 & Ecuador & C. frutescens & eIF4E_G1 & eIF(iso)4E_C2 \\
\hline CDP007314 & Ecuador & C. frutescens & $e I F 4 E \_F 3$ & eIF(iso)4E_BI \\
\hline CDP000348 & Ecuador & C. frutescens & $e I F 4 E \_F 3$ & eIF(iso)4E_Bl \\
\hline CDP006081 & Ecuador & C. frutescens & $e I F 4 E \_F 3$ & eIF(iso)4E_Bl \\
\hline CDP002872 & Ecuador & C. frutescens & $e I F 4 E_{-} F 2$ & eIF(iso)4E_BI \\
\hline CDP000815 & Ecuador & C. frutescens & NO AMPLIFICATION & eIF(iso)4E_Bl \\
\hline CDP001686 & Ecuador & C. frutescens & $e I F 4 E_{-} F 2$ & eIF(iso)4E_Bl \\
\hline CDP006569 & Ecuador & C. frutescens & $e I F 4 E \_G 1$ & eIF(iso)4E_BI \\
\hline CDP003572 & Ecuador & C. frutescens & $e I F 4 E \_G l$ & eIF(iso)4E_Bl \\
\hline CDP004334 & Ecuador & C. frutescens & NO AMPLIFICATION & eIF(iso)4E_Bl \\
\hline CDP002010 & Ecuador & C. frutescens & $e I F 4 E \_G 1$ & eIF(iso)4E_BI \\
\hline CDP005838 & Ecuador & C. frutescens & $e I F 4 E_{-} F 3$ & eIF(iso)4E_Bl \\
\hline CDP005436 & Ecuador & C. frutescens & $e I F 4 E \_G l$ & eIF(iso)4E_Bl \\
\hline CDP000914 & Ecuador & C. frutescens & $e I F 4 E_{-} F 2$ & eIF(iso)4E_Bl \\
\hline CDP006811 & Ecuador & C. frutescens & $e I F 4 E \_G 1$ & eIF(iso)4E_B1 \\
\hline CDP004750 & Ecuador & C. frutescens & $e I F 4 E_{-} F 2$ & eIF(iso) $4 E \_B 1$ \\
\hline CDP006277 & Bolivia & C. frutescens & NO AMPLIFICATION & eIF(iso) $4 E \_B I$ \\
\hline CDP006951 & Ecuador & C. frutescens & $e I F 4 E_{-} R 1$ & eIF(iso) $4 E \_B 1$ \\
\hline CDP001137 & Ecuador & C. frutescens & $e I F 4 E_{-} F 3$ & eIF(iso)4E_BI \\
\hline CDP007525 & Ecuador (Galapagos Islands) & C. frutescens & $e I F 4 E_{-} F 2$ & eIF(iso) $4 E_{-} B 1$ \\
\hline
\end{tabular}




\begin{tabular}{|c|c|c|c|c|}
\hline Accession & Country & Species & eIF4E Haplotype & eIF(iso)4E Haplotype \\
\hline CDP009581 & Bolivia & C. pubescens & NO AMPLIFICATION & eIF(iso)4E_HI \\
\hline CDP008229 & Bolivia & C. pubescens & NO AMPLIFICATION & eIF(iso)4E_HI \\
\hline CDP002311 & Bolivia & C. pubescens & NO AMPLIFICATION & eIF(iso)4E_Jhet \\
\hline CDP000101 & Bolivia & C. pubescens & NO AMPLIFICATION & eIF(iso)4E_HI \\
\hline CDP006400 & Bolivia & C. pubescens & NO AMPLIFICATION & eIF(iso)4E_HI \\
\hline CDP007939 & Bolivia & C. pubescens & NO AMPLIFICATION & eIF(iso) $4 E_{-} H I$ \\
\hline CDP002317 & Bolivia & C. pubescens & NO AMPLIFICATION & eIF(iso) $4 E_{-} G 2$ \\
\hline CDP005934 & Bolivia & C. pubescens & NO AMPLIFICATION & eIF(iso)4E_HI \\
\hline CDP006145 & Bolivia & C. pubescens & NO AMPLIFICATION & eIF(iso) $4 E_{-} H I$ \\
\hline CDP004295 & Bolivia & C. pubescens & NO AMPLIFICATION & eIF(iso)4E_HI \\
\hline CDP005415 & Chile & C. pubescens & NO AMPLIFICATION & eIF(iso)4E_HI \\
\hline CDP003836 & Ecuador & C. pubescens & $e I F 4 E \_J 1$ & eIF(iso)4E_HI \\
\hline CDP006906 & Ecuador & C. pubescens & $e I F 4 E \_J 1$ & eIF(iso)4E_G2 \\
\hline CDP003173 & Ecuador & C. pubescens & $e I F 4 E \_J I$ & eIF(iso)4E_Gl \\
\hline CDP007767 & Ecuador & C. pubescens & NO AMPLIFICATION & eIF(iso)4E_Gl \\
\hline CDP009979 & Ecuador & C. pubescens & NO AMPLIFICATION & eIF(iso)4E_G2 \\
\hline CDP007610 & Ecuador & C. pubescens & $e I F 4 E \_J 1$ & eIF(iso)4E_Gl \\
\hline CDP009338 & Ecuador & C. pubescens & $e I F 4 E \_J I$ & eIF(iso)4E_HI \\
\hline CDP004601 & Ecuador & C. pubescens & $e I F 4 E \_J 1$ & eIF(iso)4E_HI \\
\hline CDP004623 & Ecuador & C. pubescens & NO AMPLIFICATION & eIF(iso)4E_Gl \\
\hline CDP007147 & Ecuador & C. pubescens & $e I F 4 E \_J 1$ & eIF(iso) $4 E_{-} G 2$ \\
\hline CDP002094 & Ecuador & C. pubescens & NO AMPLIFICATION & eIF(iso) $4 E_{-} G 2$ \\
\hline CDP004244 & Ecuador & C. pubescens & $e I F 4 E \_J 1$ & eIF(iso) $4 E_{-} G 1$ \\
\hline CDP005445 & Ecuador & C. pubescens & $e I F 4 E \_J I$ & $e I F(i s o) 4 E_{-} G 1$ \\
\hline CDP001488 & Ecuador & C. pubescens & $e I F 4 E \_J I$ & eIF(iso)4E_HIIhI \\
\hline CDP005115 & Ecuador & C. pubescens & $e I F 4 E \_J I$ & eIF(iso)4E_Gl \\
\hline CDP000777 & Ecuador & C. pubescens & $e I F 4 E \_J 1$ & eIF(iso)4E_Gl \\
\hline CDP003761 & Ecuador & C. pubescens & NO AMPLIFICATION & eIF(iso)4E_G2 \\
\hline CDP002337 & Ecuador & C. pubescens & $e I F 4 E \_J I$ & eIF(iso)4E_Gl \\
\hline CDP005432 & Ecuador & C. pubescens & $e I F 4 E \_J 1$ & eIF(iso)4E_Gl \\
\hline CDP004912 & Ecuador & C. pubescens & NO AMPLIFICATION & eIF(iso)4E_G2 \\
\hline CDP006976 & Ecuador & C. pubescens & $e I F 4 E \_J I$ & eIF(iso)4E_G2 \\
\hline CDP006638 & Ecuador & C. pubescens & $e I F 4 E \_J 1$ & eIF(iso) $4 E_{-} G 2$ \\
\hline CDP000590 & Ecuador & C. pubescens & $e I F 4 E \_J 1$ & eIF(iso)4E_GI \\
\hline CDP004343 & Peru & C. pubescens & $e I F 4 E \_J 1$ & eIF(iso)4E_Gl \\
\hline
\end{tabular}


Additional file 2: Alignment of predicted eIF4E proteins from different haplotypes.

pvr2+_AAM82190 eIF4E_D eIF $4 \mathrm{E}^{-} \mathrm{I}$ eIF4E_P eIF4E B eIF $4 \mathrm{E}^{-} \mathrm{A}$ eIF4E_E eIF4E_L eIF $4 \mathrm{E}^{-} \mathrm{R}$ eIF $4 \mathrm{E}^{-} \mathrm{C}$ eIF4E $F$ eIF4E_J eIF4E $Q$ eIF4E G eIF $4 \mathrm{E}^{-} \mathrm{M}$ eIF4E_N eIF4E $\mathrm{Sh}$ eIF4E_O eIF $4 \mathrm{E}^{-} \mathrm{H}$ eIF4E_K

pvr2+ AAM82190 eIF 4E D eIF4E I eIF4E $P$ eIF4E B eIF4E_A eIF4E E eIF4E $L$ eIF $4 E^{-} R$ eIF 4E ${ }^{-} \mathrm{C}$ eIF4E_F eIF4E- J eIF4E $Q$ eIF4E_G eIF 4E M eIF4E_N eIF4E Sh eIF 4E O eIF4E_H eIF4E K

pvr2+ AAM82190 eIF 4E D eIF $4 \mathrm{E}^{-} \mathrm{I}$ eIF $4 \mathrm{E}^{-} \mathrm{P}$ eIF 4E_B eIF 4 $\mathrm{E}^{-} \mathrm{A}$ eIF 4 E $E$ eIF 4 E L eIF $4 \mathrm{E}^{-} \mathrm{R}$ eIF 4E_C eIF 4E ${ }^{-} \mathrm{F}$ eIF 4E_J eIF 4E_Q eIF $4 \mathrm{E}^{-} \mathrm{G}$ eIF 4 E M eIF $4 \mathrm{E}^{-} \mathrm{N}$ eIF4E $\mathrm{Sh}$ eIF 4E_O eIF $4 \mathrm{E}^{-} \mathrm{H}$ eIF 4E_K
MATAEMEKTTTFDEAEKVKLNANEADDEVEEGEIVEETDDTTSYLSKEIATKHPLEHSWT 60 ------EKTTTFDEAEKVKLNANEADDEVEEGEIVEETDDTTSYLSKEIATKHPLEHSWT 54 ------EKTTTFDEAEKVKLNANEADDEVEEGEIVEETDDTTSYLSKEIAAKHPLEHSWT 54 ------EKTTTFDEAEKVKLNANEADDEVEEGEIVEETDDTTSYLSKEIAAKHPLEHSWT 54 -----EKTTTFDEAEKVKLNANEADDEVEEGEIVEETDDTTSYLSKEIATKHPLEHSWT 54 ------EKTTTFDEAEKVKLNANEADDEVEEGEIVEETDDTTSYLSKEIATKHPLEHSWT 54 ------EKTTTFDEAEKVKLNANEADDEVEEGEIVEETDDTTSYLSKEIATKHPLEHSWT 54 -----EKTTTFDEAEKVKLNANEADDEVEEGEIVEETDDTTSYLSKEIATKHPLEHSWT 54 -----EKTTTFDEVEKVKLNANEADDEVEEGEIVEETDDTTSYLSKEIATKHPLEHSWT 54 ------EKTTTFDETEKVKLNANEADDEVEEGEIVEETDDTTSYLSKEIATKHPLEHSWT 54 -----EKTTTFDEAEKVKLNANEADDEVEEGEIVEETDDTTSYLSKEIATKHPLEHSWT 54 ------EKTTTFDEAEKVKLNANEADDEVEEGEIVEETDDTTSYLSKEIATKHPLEHSWT 54 -----EKTTTFDEAEKVKLNANEADDEVEEGEIVEETDDTTSYLSKEIATKHPLEHSWT 54 -----EKTTTFDEAEKVKLNANEADDEVEEGEIVEETDDTTSYLSKEIATKHPLEHSWT 54 ------EKTTTFDEAEKVKLNANEADDEVEEGEIVEETDDTTSYLSKEIATKHPLEHSWT 54 ------EKTTTFDEAEKVKLNANEADDEVEEGEIVEETDDTTSYLSKEIATKHPLEHSWT 54 ------EKTTTFDEAEKVKLNANEADDEVEEGEIVEETDDTTSYLSKEIATKHPLEHSWT 54 ------EKTTTFDEAEKVKLNANEADDEVEEGEIVEETDDTTSYLSKEIATKHPLEHSWT 54 -----EKTTTFDEAEKVKLNANEADDEVEEGEIVEETDDTTSYLSKEIATKHPLEHSWT 54 ------EKTTTFDEAEKVKLNANEADDEVEEGEIVEETDDTTSYLSKEIATKHPLEHSWT 54

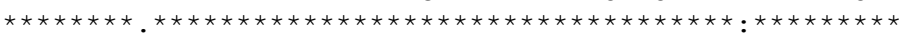

FWFDNPVAKSKQAAWGSSLRNVYTFSTVEDFWGAYNNIHHPSKLVVGADLHCFKHKIEPK 120 FWFDNTVAKSRODAWGSSLRNVYTFSTVEDFWGAYNNIHHPSKLVVRADLHCFKHKIEPK 114 FWFDNTVAKSRQAAWGSSLRNVYTFSTVEDFWGAYNNIHHPSKLVVRADLHCFKHKIEPK 114 FWFDNPVAKSRQAAWGSSLRNVYTFSTVEDFWGAYNNIHHPSKLVVGADLHCFKHKIEPK 114 FWFDNPVAKSKQAAWGSSLRNVYTFSTVEDFWGAYNNIHHPSKLVVGADLHCFKHKIEPK 114 FWFDNPEAKSKQAAWGSSRRNVYTFSTVEDFWGAYNNIHHPSKLVVGANLHCEKHKIEPK 114 FWFDNPEAKSKQAAWGSSRRNVYTFSTVEDFWGAYNNI HHPSKLVVGADLHCFKHKIEPK 114 FWFDNPVAKSRQAAWGSSRRNVYTFSTVEDFWGAYNNIHHPSKLVVGADLHCFKHKIEPK 114 FWFDNPVAKSRQAAWGSSLRNVYTFSTVEDFWGAYNNIHHPSKLVVGADLHCFKHKIEPK 114 FWFDNPVAKSROAAWGS LLRNVYTFSTVEDFWGAYNNIHHPSKLVVGADLHCFKHKIEPK 114 FWFDNPVAKSRQAAWGSSLRNVYTFSTVEDFWGAYNNIHHPSKLVVGADLHCFKHKIEPK 114 FWFDNPVAKSRQAAWGSSLRNVYTFSTVEDFWGAYNN IHHPSKLVVGADLHCFKHKIEPK 114 FWFDNPVAKSRQAAWGISLRNVYTFSTVEDFWGAYNNIHHPSKLVVGADLHCFKHKIEPK 114 FWFDNPVAKSRQAAWGSSLRNVYTFSTVEDFWGAYNNIHHPSKLVVGADLHCFKHKIEPK 114 FWFDNPVAKSROTAWGSSLRNVYTFSTVEDFWGAYNNIHHPSKLVVGADLHCFKHKIEPK 114 FWFDDPVAKSRQADWGSSLRNVYTFSTVEDFWGAYNNIHHPSKLVVGADLHCFKHKIEPK 114 FWFDDPVAKSRQADWGSSLRNVYTFSTVEDFWGAYNNIHHPSKLVVGADLHCFKHKIEPK 114 FWFDDPVAKSROAAWGSSLRNVYTFSTVEDFWGAYNNIHHPSKLVVGADLHCFKHKIEPK 114 FWFDDPVAKSRQAAWGSSLRNVYTFSTVEDFWGAYNNIHHPSKLVVGADLHCEKHKIEPK 114 FWFDDPVAKSRQDAWGSSLRNVYTFSTVEDFWGAYNNIHHPSKLVVGADLHCEKHKIEPK 114

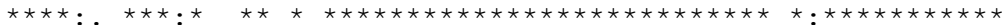

WEDPVCANGGTWKMSFSKGKSDTSWLYTLLAMIGHOFDHEDEICGAVVSVRGKGEKISLW 180 WEDPVCANGGTWKMSFSKGKSDTSWLYTLLAMIGHQFDHEDEICGAVVSVRGKGEKISLW 174 WEDPVCANGGTWKMSFSKGKSDTSWLYTLLAMIGHQFDHEDEICGAVVSVRGKGEKISLW 174 WEDPVCANGGTWKMSFSKGKSDTSWLYTLLAMIGHQFDHEDEICGAVVSVRGKGEKISLW 174 WEDPVCANGGTWKMSFSKGKSDTSWLYTLLAMIGHQFDHEDEICGAVVSVRGKGEKISLW 174 WEDPVCANGGTWKMSFSKGKSDTSWLYTLLAMIGHOFDHEDEICGAVVSVRGKGEKISLW 174 WEDPVCANGGTWKMSFSKGKSDTSWLYTLLAMIGHQFDHEDEICGAVVSVRGKGEKISLW 174 WEDPVCANGGTWKMSFSKGKSDTSWLYTLLAMIGHQFDHEDEICGAVVSVRGKGEKISLW 174 WEDPVCANGGTWKMSFSKGKSDTSWLYTLLAMIGHQFDHEDEICGAVVSVRGKGEKISLW 174 WEDPVCANGGTWKMSFSKGKSDTSWLYTLLAMIGHQFDHEDEICGAVVSVRGKGEKISLW 174 WEDPVCANGGTWKMSFSKGKSDTSWLYTLLAMIGHQFDHEDEICGAVVSVRGKGEKISLW 174 WEDPVCANGGTWKMSFSKGKSDTSWLYTLLAMIGHOFDHGDEICGAVVSVRGKGEKISLW 174 WEDPVCANGGTWKMSFSKGKSDTSWLYTLLAMIGHQFDHEDE ICGAVVSVRGKGEKISLW 174 WEDPVCANGGIWKMSFSKGKSDTSWLYTLLAMIGHOFDHEDEICGAVVSVRGKGEKISLW 174 WEDPVCANGGTWKMSFSKGKSDTSWLYTLLAMIGHQFDHEDEICGAVVSVRGKGEKISLW 174 WEDPVCANGGTWKMSFSKGKSDTSWLYTLLAMIGHQFDHEDEICGAVVSVRGKGEKISLW 174 WEDPVCANGGIWKMSFSKGKSDTSWLYTLLAMIGHQFDHEDEICGAVVSVRGKGEKISLW 174 WEDPVCANGGTWKMSFSKGKSDTSWLYTLLAMIGHQFDHEDEICGAVVSVRGKGEKISLW 174 WEDPVCANGGTWKMSFSKGKSDTSWLYTLLAMIGHOFDHEDEICGAVVSVRGKGEKISLW 174 WEDPVCANGGTWKMSFSKGKSDTSWLYTLLAMIGHQFDHEDEICGAVVSVRGKGEKISLW 174

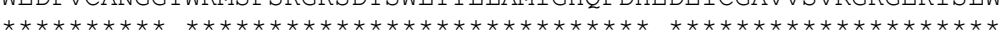


pvr2+ AAM82190 eIF 4E D eIF $4 \mathrm{E}^{-} \mathrm{I}$ eIF 4E eIF 4E_B eIF 4E ${ }^{-} \mathrm{A}$ eIF4E_E eIF4E_L eIF $4 \mathrm{E}^{-} \mathrm{R}$ eIF 4 E ${ }^{-} \mathrm{C}$ eIF $4 \mathrm{E}^{-} \mathrm{F}$ eIF 4 E J eIF4E_Q eIF 4 E G eIF 4E M eIF4E ${ }^{-} \mathrm{N}$ eIF4E Sh eIF 4 E eIF $4 \mathrm{E}^{-} \mathrm{H}$ eIF4E_K
TKNAANETAOVS IGKOWKOFLDYSDSVGFIFHDDAKRLDRNAKNRYTV 228 TKNAANETAQVSIGKQWKQFLDYSDSVGFIFHDDAKRFDRNAKNRYTV 222 TKNAANETAQVSIGKQWKQFLDYSDSVGFIFHDDAKRLDRNAKNRYTV 222 TKNAANETAQVS IGKOWKQFLDYSDSVGFIFHDDAKRLDRNAKNRYTV 222 TKNAANETAQVSIGKQWKQFLDYSDSVGFIFHDDAKRLDRNAKNRYTV 222 TKNAANETAQVS IGKQWKQFLDYSDSVGFIFHDDAKRLDRNAKNRYTV 222 TKNAANETAOVSIGKOWKOFLDYSDSVGFIFHDDAKRLDRNAKNRYTV 222 TKNAANETAQVSIGKQWKQFLDYSDSVGFIFHDDAKRLDRNAKNRYTV 222 TKNAANETAQVS IGKOWKQFLDYSDSVGFIFHDDAKRLDRNAKNRYTV 222 TKNAANETAQVSIGKQWKQFLDYSDSVGFIFHDDAKRLDRNAKNRYTV 222 TKNAANETAQVSIGKQWKQFLDYSDSVGFIFHDDAKRLDRNAKNRYTV 222 TKNAANETAQVS IGKOWKQFLDYSDSVGFIFHDEAARLERNAKNRYTV 222 TKNAANETAQVSIGKQWKQFLDYSDSVGFIFHDDAKRLDRNAKNRYTV 222 TKNAANETAQVS IGKQWKQFLDYSDSVGFIFHDDAKRLDRNAKNRYTV 222 TKNAANETAQVS IGKQWKQFLDYSDSVGFIFHDDAKRLDRNAKNRYTV 222 TKNAANETAQVS IGKQWKQFLDYSDSVGFIFHDDAKRLDRNAKNRYTV 222 TKNAANETAOVS IGKOWKOFLDYSDSVGFIFHDDAKRLDRSAKNRYTV 222 TKNAANETAQVSIGKQWKQFLDYSDSVGFIFHDDAKRLDRNAKNRYTV 222 TKNAANETAQVS IGKQWKQFLDYSDSVGFIFHHDAKRRDRNAKNRYTV 222 TKNAANETAOVSIGKOWKOFLDYSDSVGFIFHDDAKRLDRNAKNRYTV 222

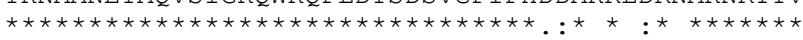

\section{Additional file 3: Alignment of predicted eIF(iso)4E proteins from different haplotypes.}

pvr6+_AAY62609 eIF iso $4 \mathrm{E} \mathrm{H}$ eIF ${ }^{-}$iso $4 \mathrm{E}^{-} \mathrm{Ih}$ eIF- iso- $4 \mathrm{E}^{-} \mathrm{G}$ eIF-iso-4 ${ }^{-} \mathrm{E}$ eIF iso $4 \mathrm{E}^{-} \mathrm{A}$ eIF_iso-4E-D eIF iso $4 \mathrm{E}^{-} \mathrm{B}$ eIF ${ }^{-}$iso ${ }^{-} 4 \mathrm{E}^{-} \mathrm{F}$ eIF iso $4 \mathrm{E}^{-} \mathrm{C}$ eIF ${ }^{-}$iso ${ }^{-} \mathrm{E}^{-} \mathrm{K}$

pvr6+ AAY62609 eIF_iso_4E_H eIF ${ }^{-}$iso ${ }^{-} \mathrm{E}^{-}$Ih eIF iso $4 \mathrm{E} G$ eIF_iso_4E-E eIF ${ }^{-}$iso $^{-} 4 \mathrm{E}^{-} \mathrm{A}$ eIF ${ }^{-}$iso $4 \mathrm{E}^{-} \mathrm{D}$ eIF_iso_4E-B eIF iso $4 \mathrm{E} F$ eIF ${ }^{-}$iso $4 \mathrm{E}^{-} \mathrm{C}$ eIF_iso_4E_K

pvr6+ AAY62609 eIF iso $4 \mathrm{E} \mathrm{H}$ eIF_iso-4E-Ih eIF ${ }^{-}$iso $4 \mathrm{E}^{-} \mathrm{G}$ eIF iso $4 \mathrm{E}$ E eIF_iso_4E_A eIF ${ }^{-}$iso ${ }^{-} 4 \mathrm{E}^{-} \mathrm{D}$ eIF iso $4 \mathrm{E}$ B eIF iso ${ }^{-} \mathrm{E}^{-} \mathrm{F}$ eIF iso $4 \mathrm{E} C$ eIF_iso_4 ${ }^{-}{ }^{-} \mathrm{K}$
MATEAPPPVDTTEVPPFTAAETAVKQPHKLERKWTFWFDNQSKPKQGAAWGSSLKKAYTF 60 ----APPPVDTTEVPPFTAEETAAKQPHKLERKWTFWFDNQSKPKQGAAWGSSLKKAYTF 56 ----APPPVDTTEVPPFTAEETASKQPHKLERKWTFWFDNQSKPKQGAAWGSSLKKAYTF 56 ----APPPVDTTEVPPFTAEETAAKQPHKLERKWTFWFDNQSKPKQGAAWGSSLKKAYTF 56 ----APP PVDTTEVPPFTAEETAVKQPHKLERKWTFWFDNQSKPKQGAAWGSSLKKAYTF 56 ----APPPVDTTEVPPFTATETAVKQPHKLERKWTFWFDNQSKPKQGAAWGSSLKKAYTF 56 ----APPPVDTTEVPPFTAAETAVKQPHKLERKWTFWFDNQSKPKQGAAWGSSLKKAYTF 56 ----APPPVDTTEVPPFTAAETAVKQSHKLERKWTFWFDNQSKPKQGAAWGSSLKKAYTF 56 ----APPPVDTTEVPTFTAAETAVKQPHKLERKWTFWFDNQSKPKQGAAWGSSLKKAYTF 56 ----APPPVDTTEVPPFTAAETAVKQPHKLERKWTFWFDNQSKPKQGAAWGSSLKKAYTF 56 ----APPPVDTTEVTPFTAAETAEKQPHKLERKWTFWFDNQSKPKQGAAWGSSLKNAYTF 56

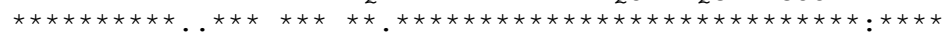

DTVEEFWSLYDQIFKPSKLTVNADFHLFKAGIEPKWEDPECANGGKWTVTSSRKANLETM 120 DTIEEFWSLYDQIFKPSKLTVNADFHLFKAGIEPKWEDPECANGGKWTVTSSRKANLETM 116 DTIEEFWSLYDQIFKPSKLTVNADFHLFKAGIEPKWEDPECANGGKWTVTSSRKANLETM 116 DTVEEFWSLYDQIFKPSKLTVNADFHLFKAGIEPKWEDPECANGGKWTVTSSRKANLETM 116 DTVEEFWSLYDQIFKPSKLTVNADFHLFKAGIEPKWEDPECANGGKWTVTSSRKANLEIM 116 DTVEEFWSLYDQIFKPSKLTVNADFHLFKAGIEPKWEDPECANGGKWTVTSSRKANLETM 116 DTVEEFWSLYDQIFKPSKLTVNADFHLFKTGIEPKWEDPECANGGKWTVTSSRKANLETM 116 DTVEEFWSLYDQIFKPSKLTVNADFHLFKTGIEPKWEDPECANGGKWTVTSSRKANLETM 116 DTVEEFWSLYDOIFKPSKLTVNADFHLFKAGIEPKWEDPECANGGKWTVTSSRKANLETM 116 DTVEEFWSLYDQIFKPSKLTVNADFHLFKAGIEPKWEDPECANGGKWTVTSSRKANLETM 116 DTVEEFWSLYDQIFKPSKLTVNADFHLFKAGIEPKWEDPECANGGKWTVTSSRKPNLETM 116

WLETLMALVGEQFDDSEDICGVVASVRRSQDKLSLWTKTATNEAAQMGIGRKWKEIIDTE 180 WLETLMALVGEOFDDSEDICGVVASVRRSODKLSLWTKTATNEAAOMGIGRKWKEIIDTE 176 WLETLMALVGEQFDDSEDICGVVASVRRSQDKLSLWTKTATNEAAQMGIGRKWKEIIDTE 176 WLETLMALVGEQFDDSEDICGVVASVRRSQDKLSLWTKTATNEAAQMGIGRKWKEI IDTE 176 WLETLMALVGEQFDDSEDICGVVASVRRSQDKLSLWTKTATNEAAQMGIGRKWKEI IDTE 176 WLETLMALVGEQFDDSEDICGVVASVRRSQDKLSLWTKTATNEAAQMGIGRKWKEIIDTE 176 WLETLMALVGEQFDDSEDICGVVASVRRSQDKLSLWTKTATNEAAQMGIGRKWKEI IDTE 176 WLETLMALVGEQFDDSEDICGVVASVRRSQDKLSLWTKTATNEAAQMGIGRKWKEIIDTE 176 WLETLMALVGEQFDDSEDICGVVASVRRSQDKLSLWTKTATNEAAQMGIGRKWKEIIDTE 176 WLETLMALVGEOFDDSEDICGVVASVRRSODKLSLWTKTATNEAAOMGIGRKWKEI IDTE 176 WLETLMALVGEQFDDSEDICGVVASVRRSQDKLSLWTKTATNEAAQMGIGRKWKEIIDTE 176 
pvr6+ AAY62609

eIF_iso_4E_H

eIF ${ }^{-}$iso $4 \mathrm{E}^{-}$Ih

eIF iso $4 \mathrm{E} \mathrm{G}$

eIF_iso_4E_E

eIF iso $4 \mathrm{E} A$

eIF iso 4E D

eIF-iso-4E-B

eIF iso $4 \mathrm{E} \mathrm{F}$

eIF_iso_4 E_C

eIF iso $4 \mathrm{E}^{-} \mathrm{K}$
KISYSFHDDSKRERSAKSRYTV 202

KISYSFHDDSKRERSAKSRYTV 198

KISYSFHDDSKRERSAKSRYTV 198

KISYSFHDDSKRERSAKSRYTV 198

KISYSFHDDSKRERSAKSRYTV 198

KISYSFHDDSKRERSAKSRYTV 198

KISYSFHDDSKRERSAKSRYTV 198

KISYSFHDDSKRERSAKSRYTV 198

KISYSFHDDSKRERSAKSRYTV 198

KISYSFHDDSKRERSAKSRYTV 198

KISYSFHDDSKRERSAKSRYTV 198

Additional file 4: Analysis to determine that translation initiation factor is involved in PVY resistance.

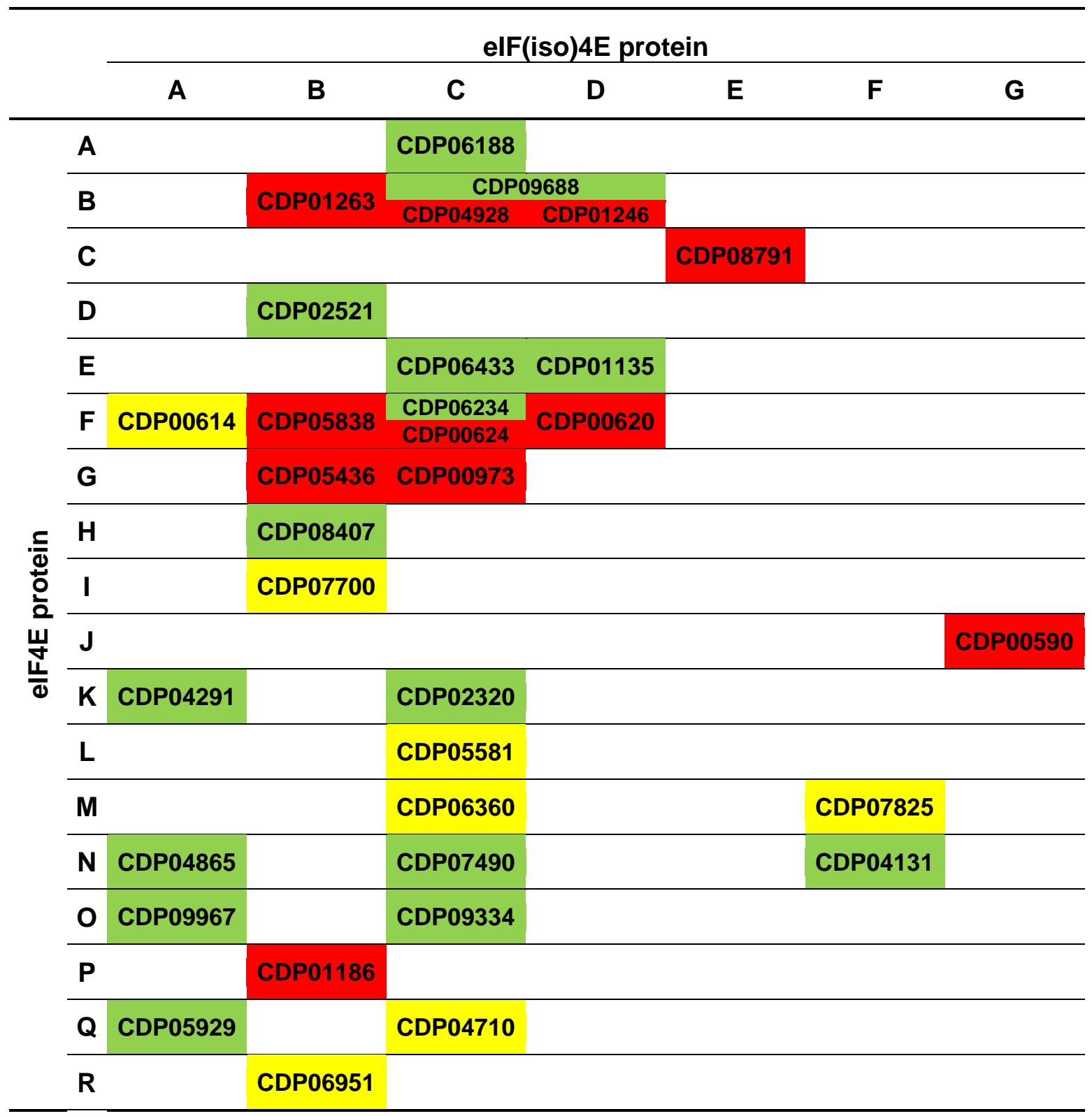


Additional file 5: EcoTILLING gel image of first classification made to $e I F($ iso $) 4 E$ gene.

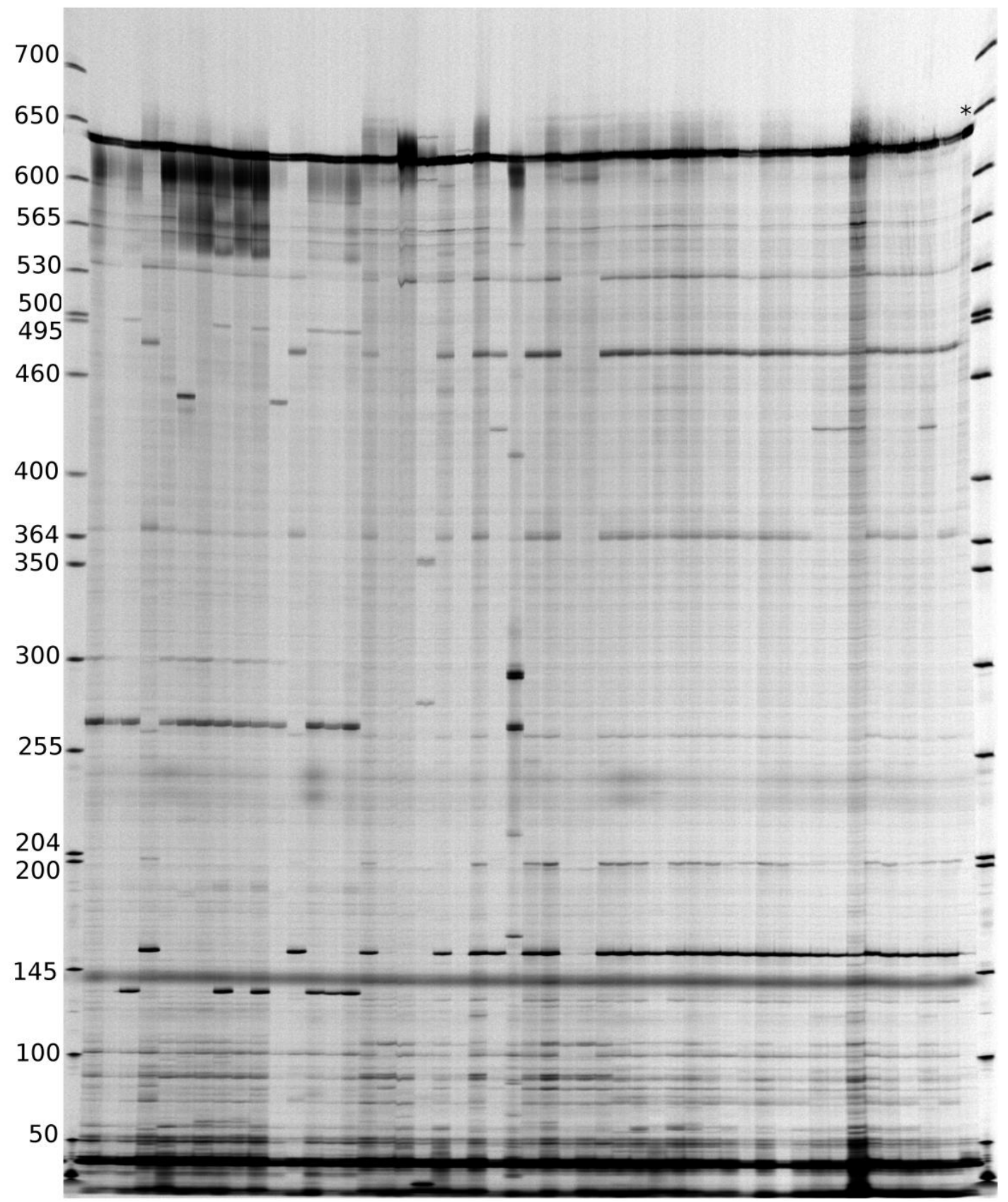


Additional file 6: EcoTILLING gel image of second classification made to $e I F 4 E$ gene.

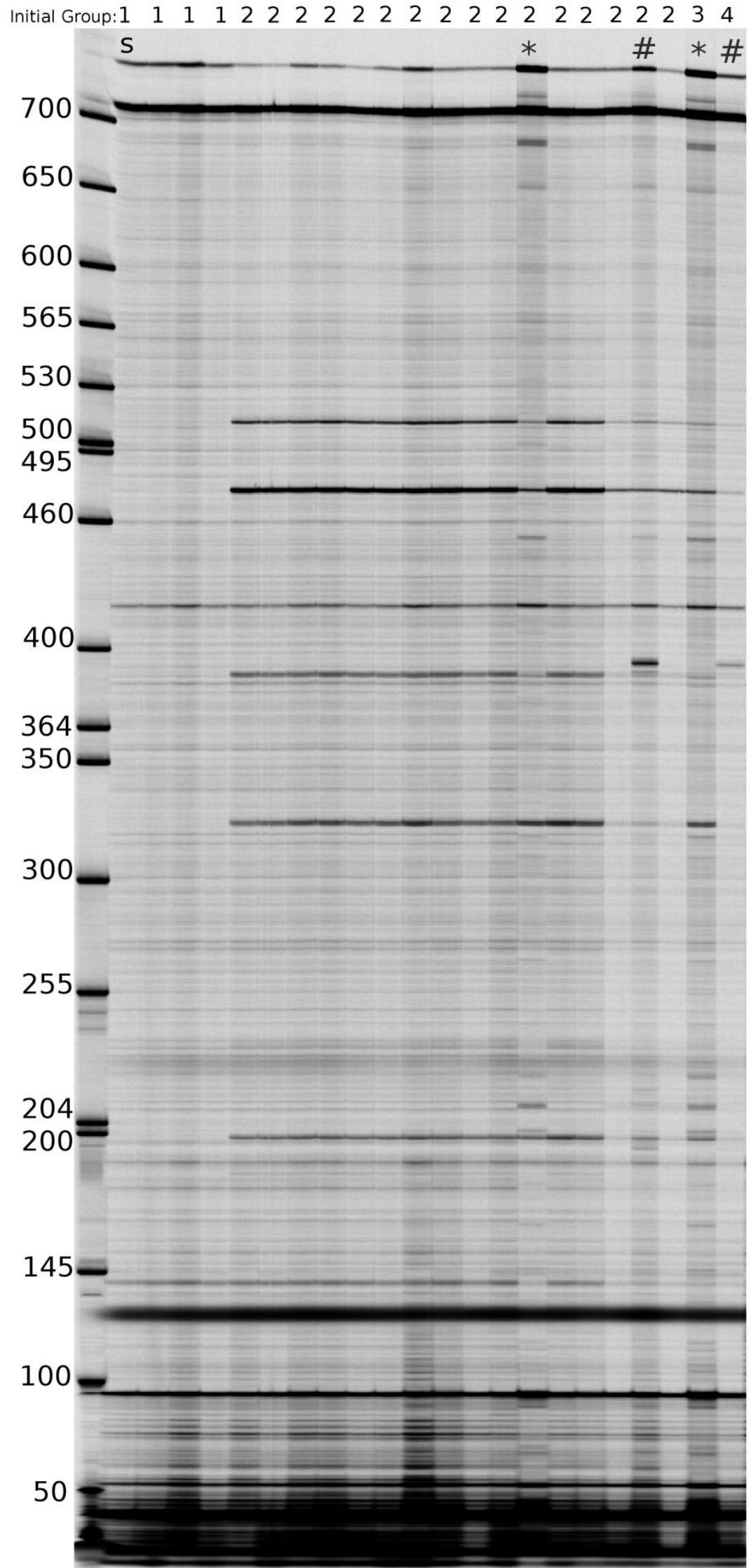



Exploiting the potential of pepper germplasm to identify new tolerance alleles of the $e I F 4 E$ gene against Tobacco etch virus 

Table 1 Percentages of DAS-ELISA-positive plants and dead plants during the mechanical inoculation survey.

\begin{tabular}{|c|c|c|c|c|c|}
\hline \multirow{2}{*}{ Accession } & \multicolumn{4}{|c|}{ \% DAS-ELISA-positive plants } & \multirow{2}{*}{$\begin{array}{l}\% \text { dead } \\
\text { plants }\end{array}$} \\
\hline & 15 DPI* & 30 DPI & 45 DPI & 60 DPI & \\
\hline CDP06188 & 0 & 25 & 100 & 100 & 0 \\
\hline CDP09688 & 100 & 80 & 20 & 0 & 0 \\
\hline CDP02657 & 100 & 100 & 100 & 100 & 0 \\
\hline CDP01263 & 100 & 100 & 100 & 100 & 0 \\
\hline CDP04928 & 100 & 100 & 60 & 80 & 0 \\
\hline CDP01246 & 100 & 100 & 20 & 80 & 0 \\
\hline CDP08791 & 100 & 100 & 100 & 100 & 0 \\
\hline CDP02521 & 80 & 100 & 100 & 100 & 0 \\
\hline CDP06433 & 100 & 100 & 100 & 100 & 0 \\
\hline CDP01135 & 100 & 100 & 100 & 100 & 0 \\
\hline CDP00614 & 100 & 100 & 100 & 100 & 0 \\
\hline CDP05838 & 100 & 100 & 100 & 100 & 0 \\
\hline CDP07553 & 100 & 100 & 100 & 100 & 0 \\
\hline CDP00624 & 100 & 100 & 100 & 100 & 0 \\
\hline CDP06234 & 100 & 100 & 100 & 75 & 0 \\
\hline CDP00620 & 100 & 100 & 100 & 100 & 0 \\
\hline CDP05436 & 100 & 100 & 100 & 100 & 40 \\
\hline CDP00973 & 100 & 100 & 100 & 100 & 0 \\
\hline CDP08407 & 100 & 100 & 100 & 100 & 0 \\
\hline CDP07700 & 0 & 60 & 100 & 100 & 0 \\
\hline CDP00590 & 100 & 100 & 80 & 100 & 0 \\
\hline CDP04291 & 100 & 100 & 100 & 100 & 0 \\
\hline CDP02320 & 100 & 100 & 80 & 100 & 0 \\
\hline CDP05581 & 100 & 100 & 100 & 100 & 0 \\
\hline CDP06360 & 100 & 100 & 100 & 100 & 0 \\
\hline CDP07825 & 100 & 100 & 100 & 100 & 0 \\
\hline CDP04865 & 100 & 100 & 100 & 100 & 0 \\
\hline CDP07490 & 100 & 100 & 60 & 100 & 0 \\
\hline CDP04131 & 100 & 100 & 100 & 100 & 0 \\
\hline CDP09967 & 100 & 100 & 100 & 100 & 0 \\
\hline CDP09334 & 100 & 100 & 100 & 100 & 0 \\
\hline CDP01186 & 100 & 100 & 100 & 100 & 0 \\
\hline CDP05929 & 100 & 100 & 100 & 100 & 0 \\
\hline CDP04710 & 100 & 100 & 100 & 100 & 0 \\
\hline CDP06951 & 100 & 100 & 100 & 100 & 0 \\
\hline Negral & 100 & 100 & 100 & 100 & 0 \\
\hline Agridulce & 100 & 100 & 100 & 100 & 0 \\
\hline
\end{tabular}

*DPI, Days post-inoculation. 
Table 2 Analysis to determine what translation initiation factor is involved in TEV resistance.*

\begin{tabular}{|c|c|c|c|c|c|c|c|c|}
\hline & \multicolumn{7}{|c|}{$e I F($ iso) $4 E$ allele } \\
\hline & & $p v r 6^{2}$ & $p v r 6^{3}$ & $p v r \sigma^{+}$ & $p v r 6^{4}$ & $p v r 6^{5}$ & $p v r 6^{6}$ & pvr6 ${ }^{9}$ \\
\hline & $p v r 2^{2}$ & & & CDP06188 & & & & \\
\hline & nurp $?^{+}$ & & CDD01263 & CDP & 2657 & & & \\
\hline & & & & CDP04928 & CDP01246 & & & \\
\hline & $p v r 2^{15}$ & & & & & CDP08791 & & \\
\hline & $p v r 2^{10}$ & & CDP02521 & & & & & \\
\hline & $p v r 2^{1}$ & & & CDP06433 & CDP01135 & & & \\
\hline & $\mathrm{n}^{+}$ & CDPOnG14 & CDP07553 & CDP00624 & CDDongen & & & \\
\hline & port & CDF 00014 & CDP05838 & CDP06234 & CDF 00020 & & & \\
\hline & $p v r 2^{16}$ & & CDP05436 & CDP00973 & & & & \\
\hline & $p v r 2^{11}$ & & CDP08407 & & & & & \\
\hline 㐫 & pvrl & & CDP07700 & & & & & \\
\hline$\frac{\pi}{2}$ & $p v r 2^{18}$ & & & & & & & CDP00590 \\
\hline & $p v r 2^{12}$ & CDP04291 & & CDP02320 & & & & \\
\hline & $p v r 2^{19}$ & & & CDP05581 & & & & \\
\hline & $p v r 2^{20}$ & & & CDP06360 & & & CDP07825 & \\
\hline & $p v r 2^{13}$ & CDP04865 & & CDP07490 & & & CDP04131 & \\
\hline & $p v r 2^{14}$ & CDP09967 & & CDP09334 & & & & \\
\hline & $p v r 2^{21}$ & & CDP01186 & & & & & \\
\hline & $p v r 2^{22}$ & CDP05929 & & CDP04710 & & & & \\
\hline & $p v r 2^{17}$ & & CDP06951 & & & & & \\
\hline
\end{tabular}

* Tolerant accessions are highlighted in green and susceptible accessions in red. 


\section{Taxonomy and genetic diversity of domesticated Capsicum species in the Andean region}



Supplemental Fig. 1 PCoA performed with AFLP data of $C$. chinense and $C$. frutescens.

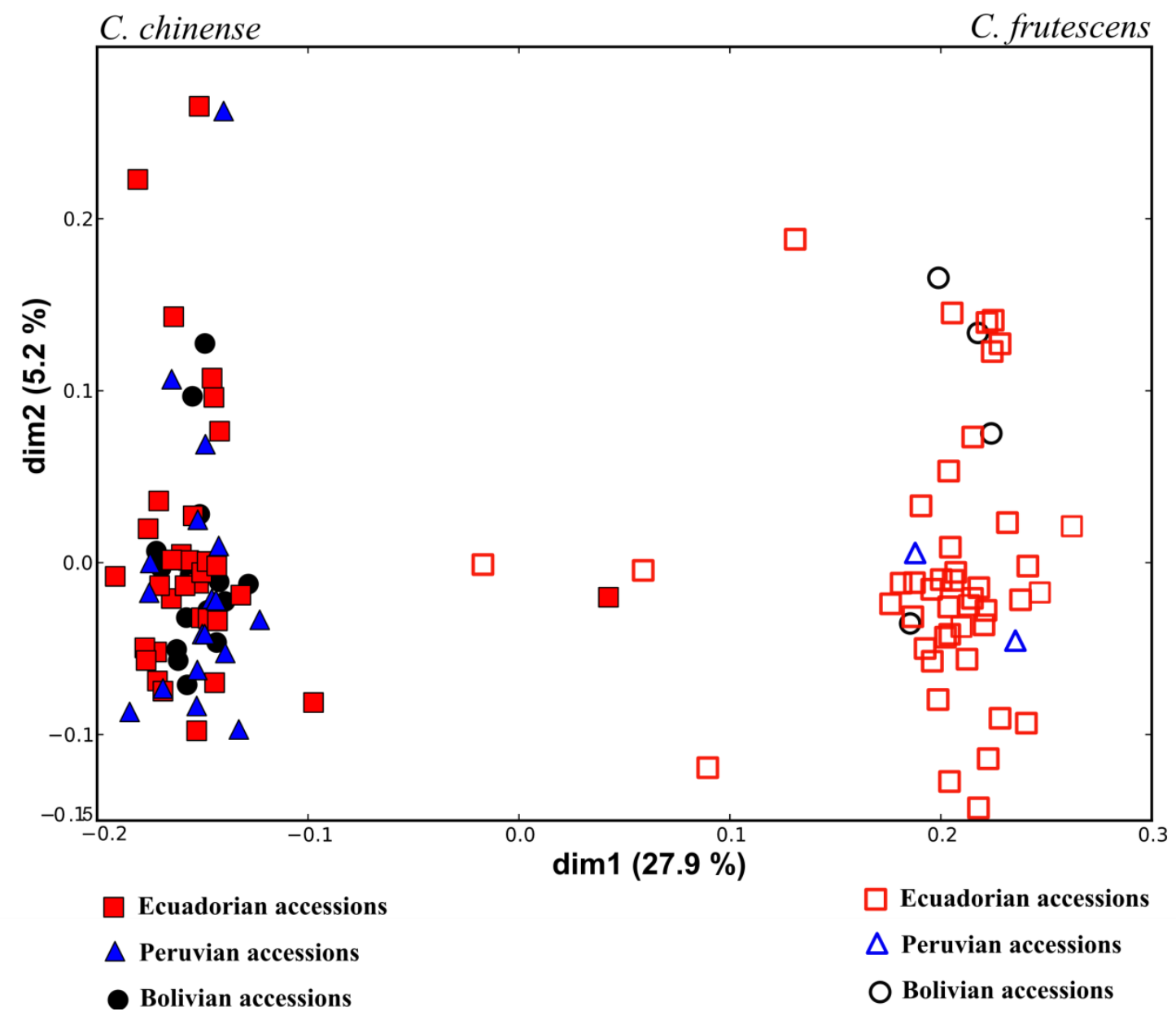


Supplemental Table 1 List of accessions used in this study, including taxonomic classification, accession identifiers, and geographic coordinates for the collection sites.

\begin{tabular}{|c|c|c|c|c|c|c|}
\hline $\begin{array}{l}\text { Accession } \\
\text { number }\end{array}$ & Species & Provided by & Latitude (S) & Longitude (W) & Altitude (m) & Country \\
\hline BGV013128 & C. аппиит & COMAV & $172210 \mathrm{~S}$ & $0661017 \mathrm{~W}$ & 2597 & Bolivia \\
\hline BGV007630 & C. аппиит & COMAV & $172303 \mathrm{~S}$ & $0660805 \mathrm{~W}$ & 2575 & Bolivia \\
\hline BGV007689 & C. апnиит & COMAV & 1747--S & 06310--W & 416 & Bolivia \\
\hline PI439212 & C. апnиит & USDA & - & - & - & Bolivia \\
\hline CGN20808 & C. аппиит & CGN & $164159 \mathrm{~S}$ & $0642512 \mathrm{~W}$ & - & Bolivia \\
\hline PI213917 & C. аппиит & USDA & - & - & - & Bolivia \\
\hline PI260436 & C. аппиит & USDA & - & - & - & Bolivia \\
\hline PI260588 & C. апnиит & USDA & - & - & - & Bolivia \\
\hline PI645508 & C. аппиит & USDA & - & - & - & Bolivia \\
\hline BGV006982 & C. аппиит & COMAV & 0253--S & 07901--W & 2450 & Ecuador \\
\hline BGV006989 & C. апnиuт & COMAV & - & - & - & Ecuador \\
\hline BGV007031 & C. annuит & COMAV & 000605S & $0782526 \mathrm{~W}$ & 2690 & Ecuador \\
\hline BGV005981 & C. апnиит & COMAV & - & - & - & Ecuador \\
\hline BGV006085 & C. апnиит & COMAV & $035505 \mathrm{~S}$ & 0791856W & 2600 & Ecuador \\
\hline BGV006160 & C. аппиит & COMAV & 034750S & 0793809W & 1150 & Ecuador \\
\hline BGV005857 & C. аппиит & COMAV & - & - & - & Ecuador \\
\hline BGV006193 & C. аппиит & COMAV & 0335--S & 07928--W & 200 & Ecuador \\
\hline BGV006445 & C. апnиит & COMAV & 1325--S & 07151--W & - & Peru \\
\hline BGV006480 & C. апnиит & COMAV & - & - & - & Peru \\
\hline BGV007428 & C. апnиит & COMAV & 1130--S & 07550--W & 3680 & Peru \\
\hline BGV013686 & C. аппиит & COMAV & - & - & - & Peru \\
\hline BGV013865 & C. апnиит & COMAV & $162628 \mathrm{~S}$ & 0730608W & 14 & Peru \\
\hline BGV014334 & C. апnиит & COMAV & - & - & - & Peru \\
\hline BGV014341 & C. апnиит & COMAV & 063043S & 0795127W & 60 & Peru \\
\hline BGV014363 & C. аппиит & COMAV & - & - & - & Peru \\
\hline BGV007711 & C. baccatum & COMAV & $164552 \mathrm{~S}$ & 0623439W & 244 & Bolivia \\
\hline BGV007713 & C. baccatum & COMAV & $164552 \mathrm{~S}$ & 0623439W & 244 & Bolivia \\
\hline BGV007715 & C. baccatum & COMAV & $163659 \mathrm{~S}$ & 0623000W & 279 & Bolivia \\
\hline BGV007716 & C. baccatum & COMAV & $163659 \mathrm{~S}$ & 0623000W & 279 & Bolivia \\
\hline BGV007718 & C. baccatum & COMAV & $163703 \mathrm{~S}$ & $0623005 \mathrm{~W}$ & 279 & Bolivia \\
\hline BGV007722 & C. baccatum & COMAV & $180315 \mathrm{~S}$ & 0640732W & 1266 & Bolivia \\
\hline BGV007724 & C. baccatum & COMAV & $180213 \mathrm{~S}$ & $0640623 \mathrm{~W}$ & 1256 & Bolivia \\
\hline BGV007618 & C. baccatum & COMAV & 1723--S & 06608--W & 2575 & Bolivia \\
\hline BGV007727 & C. baccatum & COMAV & $180204 S$ & $0640625 \mathrm{~W}$ & 1256 & Bolivia \\
\hline BGV007728 & C. baccatum & COMAV & $180204 \mathrm{~S}$ & $0640625 \mathrm{~W}$ & 1256 & Bolivia \\
\hline BGV007729 & C. baccatum & COMAV & $180204 \mathrm{~S}$ & $0640625 \mathrm{~W}$ & 1256 & Bolivia \\
\hline BGV007734 & C. baccatum & COMAV & $180000 \mathrm{~S}$ & 0640533W & 1235 & Bolivia \\
\hline BGV007739 & C. baccatum & COMAV & $175851 \mathrm{~S}$ & 0640156W & 1168 & Bolivia \\
\hline BGV007741 & C. baccatum & COMAV & $180054 \mathrm{~S}$ & $0640012 \mathrm{~W}$ & 1217 & Bolivia \\
\hline BGV007742 & C. baccatum & COMAV & $180054 \mathrm{~S}$ & $0640012 \mathrm{~W}$ & 1217 & Bolivia \\
\hline BGV007747 & C. baccatum & COMAV & $172458 \mathrm{~S}$ & $0635705 \mathrm{~W}$ & 325 & Bolivia \\
\hline
\end{tabular}




\begin{tabular}{|c|c|c|c|c|c|c|}
\hline $\begin{array}{l}\text { Accession } \\
\text { number }\end{array}$ & Species & Provided by & Latitude (S) & Longitude (W) & Altitude (m) & Country \\
\hline BGV007756 & C. baccatum & COMAV & 1724--S & 06353--W & 300 & Bolivia \\
\hline BGV007757 & C. baccatum & COMAV & 1724--S & 06353--W & 300 & Bolivia \\
\hline BGV007758 & C. baccatum & COMAV & 1724--S & 06353--W & 300 & Bolivia \\
\hline BGV007760 & C. baccatum & COMAV & $172428 \mathrm{~S}$ & $0634415 \mathrm{~W}$ & 298 & Bolivia \\
\hline BGV007762 & C. baccatum & COMAV & $172722 S$ & 0633945W & 327 & Bolivia \\
\hline BGV007773 & C. baccatum & COMAV & $194523 \mathrm{~S}$ & 0633343W & 1060 & Bolivia \\
\hline BGV007778 & C. baccatum & COMAV & $194852 \mathrm{~S}$ & 0634310W & 1622 & Bolivia \\
\hline BGV007783 & C. baccatum & COMAV & $195146 \mathrm{~S}$ & 0634809W & 1185 & Bolivia \\
\hline BGV007785 & C. baccatum & COMAV & $194658 \mathrm{~S}$ & 0634957W & 1160 & Bolivia \\
\hline BGV007788 & C. baccatum & COMAV & $194426 \mathrm{~S}$ & $0635224 \mathrm{~W}$ & 1165 & Bolivia \\
\hline BGV007804 & C. baccatum & COMAV & $180102 \mathrm{~S}$ & $0640625 \mathrm{~W}$ & 1246 & Bolivia \\
\hline BGV007807 & C. baccatum & COMAV & $172303 \mathrm{~S}$ & $0660805 \mathrm{~W}$ & 2858 & Bolivia \\
\hline BGV007629 & C. baccatum & COMAV & $172303 \mathrm{~S}$ & 0660805W & 2575 & Bolivia \\
\hline BGV007640 & C. baccatum & COMAV & $191757 \mathrm{~S}$ & 0642349W & 2304 & Bolivia \\
\hline BGV007643 & C. baccatum & COMAV & $191745 \mathrm{~S}$ & $0642222 \mathrm{~W}$ & 2302 & Bolivia \\
\hline BGV007644 & C. baccatum & COMAV & $191745 \mathrm{~S}$ & $0642233 \mathrm{~W}$ & 2193 & Bolivia \\
\hline BGV007647 & C. baccatum & COMAV & $191745 \mathrm{~S}$ & 0642233W & 2193 & Bolivia \\
\hline BGV007652 & C. baccatum & COMAV & $191827 \mathrm{~S}$ & 0641808W & 2125 & Bolivia \\
\hline BGV007657 & C. baccatum & COMAV & $182524 \mathrm{~S}$ & 0651300W & 2026 & Bolivia \\
\hline BGV007671 & C. baccatum & COMAV & 172210S & 0661017W & 2597 & Bolivia \\
\hline BGV007678 & C. baccatum & COMAV & 1747--S & 06310--W & 416 & Bolivia \\
\hline BGV007685 & C. baccatum & COMAV & 1747--S & 06310--W & 416 & Bolivia \\
\hline BGV007614 & C. baccatum & COMAV & 1723--S & 06608--W & 2575 & Bolivia \\
\hline BGV007694 & C. baccatum & COMAV & 1747--S & 06310--W & 416 & Bolivia \\
\hline BGV007616 & C. baccatum & COMAV & $1723--S$ & 06608--W & 2575 & Bolivia \\
\hline BGV006818 & C. baccatum & COMAV & $011123 \mathrm{~S}$ & $0775228 \mathrm{~W}$ & 545 & Ecuador \\
\hline BGV006979 & C. baccatum & COMAV & 0253--S & 07901--W & 2450 & Ecuador \\
\hline BGV006986 & C. baccatum & COMAV & 0253--S & 07901--W & 2450 & Ecuador \\
\hline BGV006987 & C. baccatum & COMAV & 0253--S & 07901--W & 2450 & Ecuador \\
\hline BGV006990 & C. baccatum & COMAV & 0253--S & 07901--W & 2450 & Ecuador \\
\hline BGV006993 & C. baccatum & COMAV & 023335S & 0785610W & 3168 & Ecuador \\
\hline BGV006994 & C. baccatum & COMAV & $023335 \mathrm{~S}$ & 0785610W & 3168 & Ecuador \\
\hline BGV007007 & C. baccatum & COMAV & 0115--S & 07837--W & 2458 & Ecuador \\
\hline BGV007021 & C. baccatum & COMAV & 012215S & $0783022 \mathrm{~W}$ & 2117 & Ecuador \\
\hline BGV007030 & C. baccatum & COMAV & $000605 \mathrm{~S}$ & $0782526 \mathrm{~W}$ & 2690 & Ecuador \\
\hline BGV007034 & C. baccatum & COMAV & $000605 \mathrm{~S}$ & $0782526 \mathrm{~W}$ & 2690 & Ecuador \\
\hline BGV007037 & C. baccatum & COMAV & $000605 \mathrm{~S}$ & $0782526 \mathrm{~W}$ & 2690 & Ecuador \\
\hline BGV007038 & C. baccatum & COMAV & $000546 \mathrm{~S}$ & $0782435 \mathrm{~W}$ & 2541 & Ecuador \\
\hline BGV007048 & C. baccatum & COMAV & $002612 \mathrm{~N}$ & $0775736 \mathrm{~W}$ & 1686 & Ecuador \\
\hline BGV007075 & C. baccatum & COMAV & $004448 \mathrm{~N}$ & 0781437W & 1038 & Ecuador \\
\hline BGV007332 & C. baccatum & COMAV & 034722S & $0800252 \mathrm{~W}$ & 16 & Ecuador \\
\hline BGV007369 & C. baccatum & COMAV & 031608S & 0791545W & 1385 & Ecuador \\
\hline BGV007371 & C. baccatum & COMAV & $030511 \mathrm{~S}$ & 0790040W & 2693 & Ecuador \\
\hline BGV007373 & C. baccatum & COMAV & $030511 \mathrm{~S}$ & $0790040 \mathrm{~W}$ & 2693 & Ecuador \\
\hline
\end{tabular}




\begin{tabular}{|c|c|c|c|c|c|c|}
\hline $\begin{array}{l}\text { Accession } \\
\text { number }\end{array}$ & Species & Provided by & Latitude (S) & Longitude (W) & Altitude (m) & Country \\
\hline BGV007376 & C. baccatum & COMAV & 031918S & 0790942W & 3099 & Ecuador \\
\hline BGV006131 & C. baccatum & COMAV & 035707S & 0792608W & 1900 & Ecuador \\
\hline BGV006131 & C. baccatum & COMAV & 035707S & 0792608W & 1900 & Ecuador \\
\hline BGV005852 & C. baccatum & COMAV & 0410--S & 07912--W & 1825 & Ecuador \\
\hline BGV006137 & C. baccatum & COMAV & 035734S & 0792905W & 2300 & Ecuador \\
\hline BGV005859 & C. baccatum & COMAV & 0414--S & 07917--W & 1800 & Ecuador \\
\hline BGV005862 & C. baccatum & COMAV & 0414--S & 07913--W & 1800 & Ecuador \\
\hline BGV006273 & C. baccatum & COMAV & $041825 \mathrm{~S}$ & 0791528W & 1700 & Ecuador \\
\hline BGV005867 & C. baccatum & COMAV & 0414--S & 07915--W & 1750 & Ecuador \\
\hline BGV005874 & C. baccatum & COMAV & - & - & - & Ecuador \\
\hline BGV005877 & C. baccatum & COMAV & 0358--S & 07920--W & - & Ecuador \\
\hline BGV006723 & C. baccatum & COMAV & 0359--S & 07912--W & 2140 & Ecuador \\
\hline BGV006746 & C. baccatum & COMAV & 002024S & 0774837W & 1606 & Ecuador \\
\hline BGV006748 & C. baccatum & COMAV & $003141 \mathrm{~S}$ & 0775256W & 1886 & Ecuador \\
\hline CGN21479 & C. baccatum & CGN & 094724S & 0744724W & - & Peru \\
\hline BGV013698 & C. baccatum & COMAV & 0510--S & 07958--W & 1000 & Peru \\
\hline BGV013709 & C. baccatum & COMAV & 0511--S & 08037--W & 24 & Peru \\
\hline BGV013835 & C. baccatum & COMAV & - & - & - & Peru \\
\hline BGV013858 & C. baccatum & COMAV & $161316 \mathrm{~S}$ & $0730335 \mathrm{~W}$ & 1646 & Peru \\
\hline BGV013881 & C. baccatum & COMAV & $173245 \mathrm{~S}$ & $0703753 \mathrm{~W}$ & 840 & Peru \\
\hline BGV014365 & C. baccatum & COMAV & 062940S & 0762029W & 380 & Peru \\
\hline BGV014374 & C. baccatum & COMAV & 070908S & $0783055 \mathrm{~W}$ & 2719 & Peru \\
\hline PI640890 & C. baccatum & USDA & - & - & - & Peru \\
\hline BGV014347 & C. baccatum & COMAV & 061408S & $0775156 \mathrm{~W}$ & 2345 & Peru \\
\hline BGV007717 & C. chinense & COMAV & $163645 \mathrm{~S}$ & 0623017W & 288 & Bolivia \\
\hline BGV007619 & C. chinense & COMAV & 1723--S & 06608--W & 2575 & Bolivia \\
\hline BGV007753 & C. chinense & COMAV & $172438 \mathrm{~S}$ & 0635313W & 300 & Bolivia \\
\hline BGV007805 & C. chinense & COMAV & $172425 \mathrm{~S}$ & 0635306W & 299 & Bolivia \\
\hline BGV007806 & C. chinense & COMAV & 1724--S & 06353--W & 300 & Bolivia \\
\hline BGV007615 & C. chinense & COMAV & 1723--S & 06608--W & 2575 & Bolivia \\
\hline CGN17045 & C. chinense & CGN & $164160 \mathrm{~S}$ & $0642512 \mathrm{~W}$ & - & Bolivia \\
\hline PI213916 & C. chinense & USDA & - & - & - & Bolivia \\
\hline PI260610 & C. chinense & USDA & - & - & - & Bolivia \\
\hline PI281303 & C. chinense & USDA & - & - & - & Bolivia \\
\hline PI543181 & C. chinense & USDA & $143000 \mathrm{~S}$ & 0673000W & 320 & Bolivia \\
\hline PI543182 & C. chinense & USDA & $143000 \mathrm{~S}$ & 0673000W & 320 & Bolivia \\
\hline PI543184 & C. chinense & USDA & $141500 \mathrm{~S}$ & 0681000W & 630 & Bolivia \\
\hline PI543193 & C. chinense & USDA & $110000 \mathrm{~S}$ & 0684500W & 200 & Bolivia \\
\hline PI543208 & C. chinense & USDA & $144800 \mathrm{~S}$ & 0645200W & 155 & Bolivia \\
\hline BGV006773 & C. chinense & COMAV & 010205S & 0774716W & 496 & Ecuador \\
\hline BGV006774 & C. chinense & COMAV & 010205S & 0774716W & 496 & Ecuador \\
\hline BGV006785 & C. chinense & COMAV & 010305S & 0774749W & 479 & Ecuador \\
\hline BGV006788 & C. chinense & COMAV & 010305S & 0774749W & 479 & Ecuador \\
\hline BGV006790 & C. chinense & COMAV & $010305 \mathrm{~S}$ & 0774749W & 479 & Ecuador \\
\hline
\end{tabular}




\begin{tabular}{|c|c|c|c|c|c|c|}
\hline $\begin{array}{l}\text { Accession } \\
\text { number }\end{array}$ & Species & Provided by & Latitude (S) & Longitude (W) & Altitude (m) & Country \\
\hline BGV006793 & C. chinense & COMAV & 010402S & $0774721 \mathrm{~W}$ & 493 & Ecuador \\
\hline BGV006801 & C. chinense & COMAV & 010718S & 0774837W & 531 & Ecuador \\
\hline BGV006812 & C. chinense & COMAV & $011012 S$ & 0775124W & 521 & Ecuador \\
\hline BGV006838 & C. chinense & COMAV & 013028S & 0775647W & 976 & Ecuador \\
\hline BGV006839 & C. chinense & COMAV & 013033S & 0775633W & 973 & Ecuador \\
\hline BGV006866 & C. chinense & COMAV & 014833S & $0774945 \mathrm{~W}$ & 907 & Ecuador \\
\hline BGV006876 & C. chinense & COMAV & 020038S & $0775633 \mathrm{~W}$ & 941 & Ecuador \\
\hline BGV006880 & C. chinense & COMAV & 021813S & 0780708W & 1043 & Ecuador \\
\hline BGV006935 & C. chinense & COMAV & 034718S & $0784505 \mathrm{~W}$ & 813 & Ecuador \\
\hline BGV007094 & C. chinense & COMAV & 0049--N & 07828--W & 640 & Ecuador \\
\hline BGV007097 & C. chinense & COMAV & $005437 \mathrm{~N}$ & 0783248W & 860 & Ecuador \\
\hline BGV007171 & C. chinense & COMAV & $000209 \mathrm{~N}$ & 0795702W & 257 & Ecuador \\
\hline BGV007247 & C. chinense & COMAV & 010235S & $0800517 \mathrm{~W}$ & 428 & Ecuador \\
\hline BGV007314 & C. chinense & COMAV & 025850S & 0794337W & 102 & Ecuador \\
\hline BGV007330 & C. chinense & COMAV & 034722S & $0800252 \mathrm{~W}$ & 16 & Ecuador \\
\hline BGV007331 & C. chinense & COMAV & 034722S & $0800252 \mathrm{~W}$ & 16 & Ecuador \\
\hline BGV007333 & C. chinense & COMAV & $034722 \mathrm{~S}$ & $0800252 \mathrm{~W}$ & 16 & Ecuador \\
\hline BGV007334 & C. chinense & COMAV & $034722 \mathrm{~S}$ & $0800252 \mathrm{~W}$ & 16 & Ecuador \\
\hline BGV007336 & C. chinense & COMAV & $034722 \mathrm{~S}$ & $0800252 \mathrm{~W}$ & 16 & Ecuador \\
\hline BGV006150 & C. chinense & COMAV & 034813S & 0793710W & 1000 & Ecuador \\
\hline BGV006151 & C. chinense & COMAV & 034810S & 0793710W & 1000 & Ecuador \\
\hline BGV006176 & C. chinense & COMAV & 033751S & 0794047W & 1325 & Ecuador \\
\hline BGV006190 & C. chinense & COMAV & 031905S & 0793517W & 575 & Ecuador \\
\hline BGV006236 & C. chinense & COMAV & 0355--S & 07853--W & 2775 & Ecuador \\
\hline BGV006733 & C. chinense & COMAV & 0359--S & 07912--W & 2140 & Ecuador \\
\hline BGV006754 & C. chinense & COMAV & $005442 \mathrm{~S}$ & 0774826W & 597 & Ecuador \\
\hline BGV006757 & C. chinense & COMAV & 005430S & 0774828W & 583 & Ecuador \\
\hline BGV007434 & C. chinense & COMAV & 1131--S & 07554--W & 3620 & Peru \\
\hline CGN22088 & C. chinense & CGN & 090900S & 0755548W & - & Peru \\
\hline BGV013697 & C. chinense & COMAV & 0511--S & 08037--W & 24 & Peru \\
\hline BGV013704 & C. chinense & COMAV & 0523--S & 07936--W & 1000 & Peru \\
\hline BGV013705 & C. chinense & COMAV & 0511--S & 08037--W & 24 & Peru \\
\hline BGV013825 & C. chinense & COMAV & - & - & - & Peru \\
\hline BGV013834 & C. chinense & COMAV & - & - & - & Peru \\
\hline BGV013860 & C. chinense & COMAV & $161316 \mathrm{~S}$ & $0730335 \mathrm{~W}$ & 1646 & Peru \\
\hline BGV013878 & C. chinense & COMAV & $171134 \mathrm{~S}$ & $0705613 \mathrm{~W}$ & 1411 & Peru \\
\hline BGV014326 & C. chinense & COMAV & - & - & - & Peru \\
\hline BGV014330 & C. chinense & COMAV & - & - & - & Peru \\
\hline BGV014338 & C. chinense & COMAV & 064221S & 0795410W & 16 & Peru \\
\hline BGV014350 & C. chinense & COMAV & 061408S & $0775156 \mathrm{~W}$ & 2345 & Peru \\
\hline BGV014364 & C. chinense & COMAV & 062940S & 0762029W & 380 & Peru \\
\hline BGV014366 & C. chinense & COMAV & 062940S & 0762029W & 380 & Peru \\
\hline BGV014376 & C. chinense & COMAV & 070908S & $0783055 \mathrm{~W}$ & 2719 & Peru \\
\hline PI260478 & C. chinense & USDA & - & - & - & Peru \\
\hline
\end{tabular}




\begin{tabular}{|c|c|c|c|c|c|c|}
\hline $\begin{array}{l}\text { Accession } \\
\text { number }\end{array}$ & Species & Provided by & Latitude (S) & Longitude (W) & Altitude (m) & Country \\
\hline PI640894 & C. chinense & USDA & - & - & - & Peru \\
\hline BGV007748 & C. frutescens & COMAV & $172420 \mathrm{~S}$ & $0635326 \mathrm{~W}$ & 297 & Bolivia \\
\hline BGV007750 & C. frutescens & COMAV & $172426 \mathrm{~S}$ & 0635310W & 292 & Bolivia \\
\hline BGV007751 & C. frutescens & COMAV & $172438 \mathrm{~S}$ & 0635313W & 300 & Bolivia \\
\hline PI439488 & C. frutescens & USDA & - & - & - & Bolivia \\
\hline BGV006918 & C. frutescens & COMAV & $032411 \mathrm{~S}$ & 0783448W & 780 & Ecuador \\
\hline BGV007107 & C. frutescens & COMAV & $005223 \mathrm{~N}$ & 0793858W & 50 & Ecuador \\
\hline BGV007128 & C. frutescens & COMAV & $005130 \mathrm{~N}$ & $0795232 \mathrm{~W}$ & 15 & Ecuador \\
\hline BGV007129 & C. frutescens & COMAV & $004535 \mathrm{~N}$ & 0793523W & 90 & Ecuador \\
\hline BGV007134 & C. frutescens & COMAV & 001450S & 0790919W & 670 & Ecuador \\
\hline BGV007140 & C. frutescens & COMAV & 001439S & 0791640W & 405 & Ecuador \\
\hline BGV007142 & C. frutescens & COMAV & $001443 \mathrm{~S}$ & 0791626W & 411 & Ecuador \\
\hline BGV007143 & C. frutescens & COMAV & $001535 \mathrm{~N}$ & 0792338W & 290 & Ecuador \\
\hline BGV007154 & C. frutescens & COMAV & $000504 \mathrm{~S}$ & 0794059W & 225 & Ecuador \\
\hline BGV007182 & C. frutescens & COMAV & $000416 \mathrm{~N}$ & $0800325 \mathrm{~W}$ & 26 & Ecuador \\
\hline BGV007195 & C. frutescens & COMAV & $001234 \mathrm{~S}$ & $0801522 \mathrm{~W}$ & 25 & Ecuador \\
\hline BGV007196 & C. frutescens & COMAV & $001234 \mathrm{~S}$ & $0801522 \mathrm{~W}$ & 25 & Ecuador \\
\hline BGV007197 & C. frutescens & COMAV & $001234 \mathrm{~S}$ & $0801522 \mathrm{~W}$ & 25 & Ecuador \\
\hline BGV007199 & C. frutescens & COMAV & 001925S & $0802026 \mathrm{~W}$ & 94 & Ecuador \\
\hline BGV007220 & C. frutescens & COMAV & 004748S & $0803012 \mathrm{~W}$ & 10 & Ecuador \\
\hline BGV007221 & C. frutescens & COMAV & 004944S & 0802940W & 18 & Ecuador \\
\hline BGV007223 & C. frutescens & COMAV & 004945S & 0802941W & 21 & Ecuador \\
\hline BGV007224 & C. frutescens & COMAV & 005136S & 0802810W & 20 & Ecuador \\
\hline BGV007226 & C. frutescens & COMAV & $005215 \mathrm{~S}$ & $0803153 \mathrm{~W}$ & 17 & Ecuador \\
\hline BGV007241 & C. frutescens & COMAV & $010218 \mathrm{~S}$ & 0801904W & 62 & Ecuador \\
\hline BGV007260 & C. frutescens & COMAV & $011932 S$ & 0803454W & 195 & Ecuador \\
\hline BGV007267 & C. frutescens & COMAV & 013150S & $0804721 \mathrm{~W}$ & 40 & Ecuador \\
\hline BGV007288 & C. frutescens & COMAV & 0207--S & 07935--W & 71 & Ecuador \\
\hline BGV007290 & C. frutescens & COMAV & 020700S & 0793560W & 71 & Ecuador \\
\hline BGV007293 & C. frutescens & COMAV & $021504 \mathrm{~S}$ & 0793819W & 35 & Ecuador \\
\hline BGV007295 & C. frutescens & COMAV & 022056S & 0793803W & 34 & Ecuador \\
\hline BGV007315 & C. frutescens & COMAV & 033219S & $0800112 \mathrm{~W}$ & 42 & Ecuador \\
\hline BGV007316 & C. frutescens & COMAV & 033204S & 0800120W & 39 & Ecuador \\
\hline BGV007318 & C. frutescens & COMAV & 033147S & $0800132 \mathrm{~W}$ & 42 & Ecuador \\
\hline BGV007319 & C. frutescens & COMAV & 033142S & 0800130W & 38 & Ecuador \\
\hline BGV007323 & C. frutescens & COMAV & 033403S & 0800337W & 64 & Ecuador \\
\hline BGV007324 & C. frutescens & COMAV & $034722 \mathrm{~S}$ & $0800252 \mathrm{~W}$ & 425 & Ecuador \\
\hline BGV007342 & C. frutescens & COMAV & 031922S & 0794956W & 31 & Ecuador \\
\hline BGV007347 & C. frutescens & COMAV & 031927S & $0794311 \mathrm{~W}$ & 120 & Ecuador \\
\hline BGV007367 & C. frutescens & COMAV & 031927S & 0793553W & 325 & Ecuador \\
\hline BGV006149 & C. frutescens & COMAV & 034729S & 0793647W & 850 & Ecuador \\
\hline BGV006182 & C. frutescens & COMAV & $032824 \mathrm{~S}$ & 0794337W & 550 & Ecuador \\
\hline BGV006184 & C. frutescens & COMAV & 031916S & $0794401 \mathrm{~W}$ & 50 & Ecuador \\
\hline BGV006185 & C. frutescens & COMAV & 031916S & $0794401 \mathrm{~W}$ & 50 & Ecuador \\
\hline
\end{tabular}




\begin{tabular}{|c|c|c|c|c|c|c|}
\hline $\begin{array}{l}\text { Accession } \\
\text { number }\end{array}$ & Species & Provided by & Latitude (S) & Longitude (W) & Altitude (m) & Country \\
\hline BGV006194 & C. frutescens & COMAV & $022713 \mathrm{~S}$ & 0792246W & 60 & Ecuador \\
\hline BGV006265 & C. frutescens & COMAV & 051113S & 0803733W & 40 & Peru \\
\hline CGN23210 & C. frutescens & CGN & 094724S & 0744724W & - & Peru \\
\hline BGV007795 & C. pubescens & COMAV & $194821 \mathrm{~S}$ & 0635728W & 1140 & Bolivia \\
\hline BGV007608 & C. pubescens & COMAV & 1723--S & 06608--W & 2575 & Bolivia \\
\hline BGV007809 & C. pubescens & COMAV & $191743 \mathrm{~S}$ & $0642222 \mathrm{~W}$ & 2302 & Bolivia \\
\hline BGV007810 & C. pubescens & COMAV & $181052 \mathrm{~S}$ & 0634957W & 1706 & Bolivia \\
\hline BGV007666 & C. pubescens & COMAV & 172210S & 0661017W & 2597 & Bolivia \\
\hline BGV007667 & C. pubescens & COMAV & 172210S & 0661017W & 2597 & Bolivia \\
\hline BGV007668 & C. pubescens & COMAV & 172210S & 0661017W & 2597 & Bolivia \\
\hline BGV007677 & C. pubescens & COMAV & 1747--S & 06310--W & 416 & Bolivia \\
\hline BGV007696 & C. pubescens & COMAV & 1747--S & 06310--W & 416 & Bolivia \\
\hline BGV007617 & C. pubescens & COMAV & 1723--S & 06608--W & 2575 & Bolivia \\
\hline PI614001 & C. pubescens & USDA & $163000 \mathrm{~S}$ & 0680900W & - & Bolivia \\
\hline BGV006889 & C. pubescens & COMAV & 022636S & 0780954W & 914 & Ecuador \\
\hline BGV006942 & C. pubescens & COMAV & 035005S & 0784540W & 820 & Ecuador \\
\hline BGV006944 & C. pubescens & COMAV & $035005 \mathrm{~S}$ & 0784540W & 820 & Ecuador \\
\hline BGV006950 & C. pubescens & COMAV & $035044 \mathrm{~S}$ & 0791719W & 2776 & Ecuador \\
\hline BGV006956 & C. pubescens & COMAV & 034558S & $0791531 \mathrm{~W}$ & 2477 & Ecuador \\
\hline BGV006959 & C. pubescens & COMAV & 034345S & 0791556W & 2525 & Ecuador \\
\hline BGV006983 & C. pubescens & COMAV & 0253--S & 07901--W & 2450 & Ecuador \\
\hline BGV006984 & C. pubescens & COMAV & 0253--S & 07901--W & 2450 & Ecuador \\
\hline BGV006985 & C. pubescens & COMAV & 0253--S & 07901--W & 2450 & Ecuador \\
\hline BGV007006 & C. pubescens & COMAV & 0115--S & 07837--W & 2458 & Ecuador \\
\hline BGV007009 & C. pubescens & COMAV & 0115--S & 07837--W & 2458 & Ecuador \\
\hline BGV007053 & C. pubescens & COMAV & $003937 \mathrm{~N}$ & 0774309W & 2960 & Ecuador \\
\hline BGV007326 & C. pubescens & COMAV & $034722 \mathrm{~S}$ & $0800252 \mathrm{~W}$ & 16 & Ecuador \\
\hline BGV007370 & C. pubescens & COMAV & 031608S & 0791545W & 1385 & Ecuador \\
\hline BGV007372 & C. pubescens & COMAV & 030511S & 0790040W & 2693 & Ecuador \\
\hline BGV007374 & C. pubescens & COMAV & 030511S & 0790040W & 2693 & Ecuador \\
\hline BGV006094 & C. pubescens & COMAV & 035330S & $0791725 \mathrm{~W}$ & 2000 & Ecuador \\
\hline BGV006098 & C. pubescens & COMAV & 035329S & 0791655W & 2050 & Ecuador \\
\hline BGV006106 & C. pubescens & COMAV & 035046S & 0791722W & 2200 & Ecuador \\
\hline BGV006111 & C. pubescens & COMAV & $034543 \mathrm{~S}$ & 0791537W & 2200 & Ecuador \\
\hline BGV006139 & C. pubescens & COMAV & 035451S & 0793202W & 1550 & Ecuador \\
\hline BGV006141 & C. pubescens & COMAV & $035452 \mathrm{~S}$ & 0793202W & 1100 & Ecuador \\
\hline BGV006222 & C. pubescens & COMAV & 025517S & 0790428W & 2775 & Ecuador \\
\hline BGV007431 & C. pubescens & COMAV & 1131--S & 07554--W & 3620 & Peru \\
\hline BGV013828 & C. pubescens & COMAV & - & - & - & Peru \\
\hline BGV013839 & C. pubescens & COMAV & - & - & - & Peru \\
\hline BGV013852 & C. pubescens & COMAV & - & - & - & Peru \\
\hline BGV013861 & C. pubescens & COMAV & $161316 \mathrm{~S}$ & $0730335 \mathrm{~W}$ & 1646 & Peru \\
\hline BGV013871 & C. pubescens & COMAV & $171134 \mathrm{~S}$ & $0705613 \mathrm{~W}$ & 1411 & Peru \\
\hline CGN22876 & C. tovarii & CGN & $094724 \mathrm{~S}$ & $0744724 \mathrm{~W}$ & - & Peru \\
\hline
\end{tabular}


Anexos

\begin{tabular}{lllllll}
\hline $\begin{array}{l}\text { Accession } \\
\text { number }\end{array}$ & Species & Provided by & Latitude (S) & Longitude (W) & Altitude (m) & Country \\
\hline CGN20497 & C. cardenasii & CGN & $164159 \mathrm{~S}$ & $0642512 \mathrm{~W}$ & - & Bolivia \\
BGV007726 & C. chacoense & COMAV & $180204 \mathrm{~S}$ & $0640625 \mathrm{~W}$ & 1256 & Bolivia \\
BGV007770 & C. chacoense & COMAV & $194036 \mathrm{~S}$ & $0633334 \mathrm{~W}$ & 859 & Bolivia \\
BGV004535 & C. chacoense & COMAV & - & - & - & Bolivia \\
PI260595 & C. praetermissum & USDA & - & - & - & Brazil \\
CGN20805 & C. praetermissum & CGN & $120000 \mathrm{~S}$ & $0534648 \mathrm{~W}$ & - & Brazil \\
BGV007656 & C. eximium & COMAV & $182524 \mathrm{~S}$ & $0651300 \mathrm{~W}$ & 2026 & Bolivia \\
944750228 & C. eximium & RUN & - & - & - & Bolivia \\
CGN21502 & C. eximium & CGN & - & - & - & - \\
\hline
\end{tabular}


